\title{
Work Plan for the Feasibility Study for Remedial Action at J-Field, Aberdeen Proving Ground, Maryland
}

by P. Benioff, C. Biang, R. Haffenden, M. Goyette, L. Martino, T. Patton, and C. Yuen

Environrnental Assessment Division,

Argonne National Laboratory, 9700 South Cass Avenue, Argonne, Illinois 60439

May 1995

Work sponsored by U.S. Army, Aberdeen Proving Ground, Directorate of Safety, Health, and Environment 
बत्

This report is printed on recycled paper. 


\section{DISCLAIMER}

Portions of this document may be illegible in electronic image products. Images are produced from the best available original document. 


\section{CONTENTS}

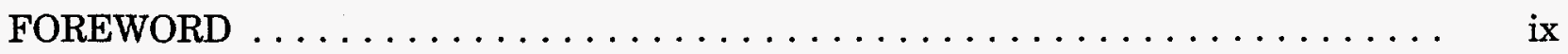

NOTATION $\ldots \ldots \ldots \ldots \ldots \ldots \ldots \ldots \ldots \ldots \ldots \ldots \ldots \ldots \ldots \ldots \ldots \ldots \ldots \ldots \ldots \ldots \ldots$

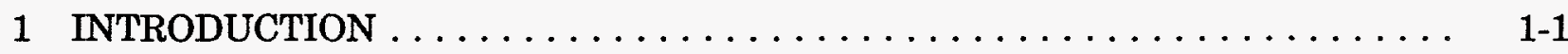

1.1 Background $\ldots \ldots \ldots \ldots \ldots \ldots \ldots \ldots \ldots \ldots \ldots \ldots \ldots \ldots \ldots \ldots \ldots \ldots \ldots \ldots, 1-1$

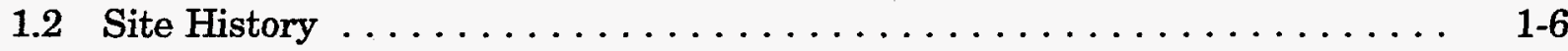

1.3 Overview of the RI/FS Process under CERCLA $\ldots \ldots \ldots \ldots \ldots \ldots \ldots$ 1-8

1.4 Purpose of the Feasibility Study Work Plan $\ldots \ldots \ldots \ldots \ldots \ldots \ldots \ldots$ 1-10

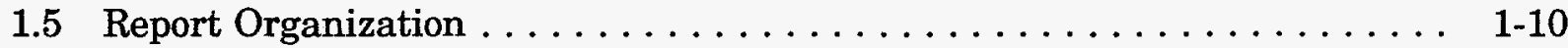

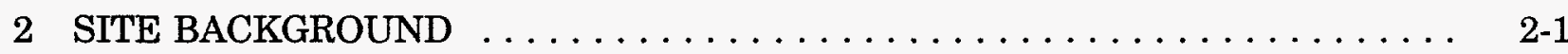

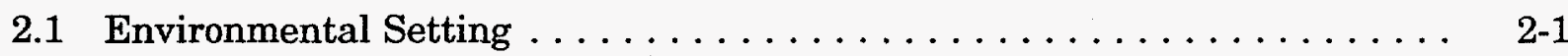

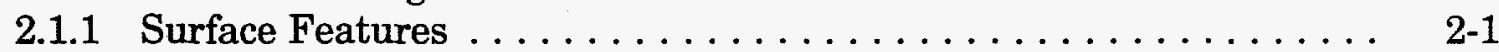

2.1.2 Climate $\ldots \ldots \ldots \ldots \ldots \ldots \ldots \ldots \ldots \ldots \ldots \ldots \ldots \ldots \ldots \ldots \ldots \ldots \ldots \ldots, 2-1$

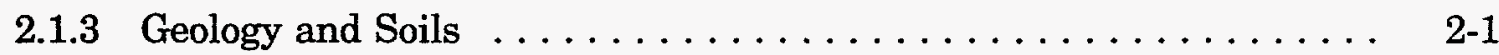

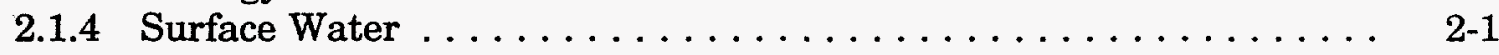

2.1.5 Groundwater $\ldots \ldots \ldots \ldots \ldots \ldots \ldots \ldots \ldots \ldots \ldots \ldots \ldots \ldots \ldots \ldots \ldots \ldots, 2-4$

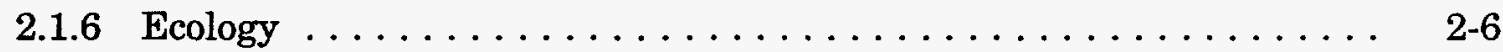

2.2 Background of J-Field Areas of Concern $\ldots \ldots \ldots \ldots \ldots \ldots \ldots \ldots \ldots$ 2-7

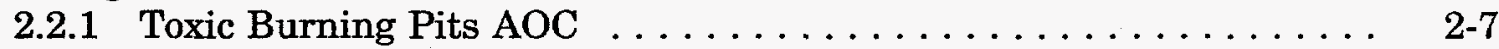

2.2.2 White Phosphorus Burning Pits AOC $\ldots \ldots \ldots \ldots \ldots \ldots \ldots .2-8$

2.2.3 Riot Control Burning Pit AOC $\ldots \ldots \ldots \ldots \ldots \ldots \ldots \ldots \ldots \ldots \ldots \ldots \ldots$

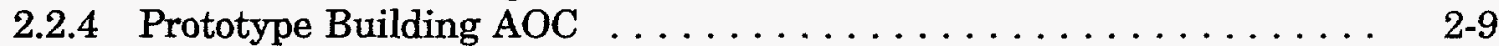

2.2.5 South Beach Demolition Ground AOC ............. 2-10

2.2.6 South Beach Trench AOC ................... 2-10

2.2.7 Robins Point Demolition Ground AOC . . . . . . . . . . . . 2-10

2.2.8 Robins Point Tower Site AOC $\ldots \ldots \ldots \ldots \ldots \ldots \ldots \ldots \ldots .2-11$

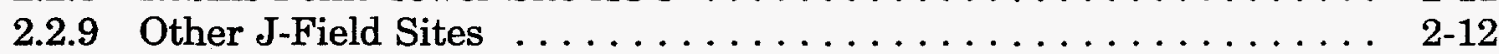

2.3 Preliminary Evaluation of J-Field Areas of Concern $\ldots \ldots \ldots \ldots \ldots \ldots$ 2-12

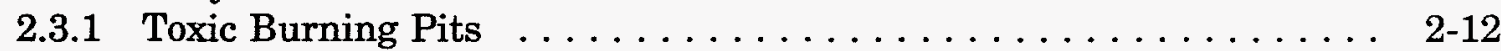

2.3.2 White Phosphorus Burning Pits $\ldots \ldots \ldots \ldots \ldots \ldots \ldots .2-43$

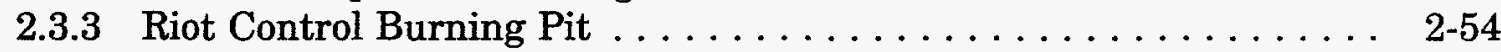

2.3.4 South Beach Trench $\ldots \ldots \ldots \ldots \ldots \ldots \ldots \ldots \ldots \ldots \ldots . \ldots \ldots 2-62$

2.3.5 South Beach Demolition Ground $\ldots \ldots \ldots \ldots \ldots \ldots \ldots \ldots \ldots$ 2-64

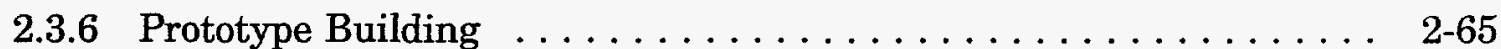

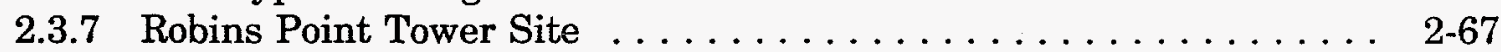

2.3.8 Robins Point Demolition Ground $\ldots \ldots \ldots \ldots \ldots \ldots \ldots \ldots \ldots \ldots$ 2-69

2.4 Other Relevant Site Aspects . . . . . . . . . . . . . . . . 2-70

2.4.1 Preliminary Identification of ARARs and TBC Information . . . . . 2 2-70

2.4.2 Preliminary Remediation Goals . . . . . . . . . . . . . 2-72

2.4.3 Preliminary Identification of Operable Units . . . . . . . . . 2-89 


\section{CONTENTS (Cont.)}

3 FEASIBILITY STUDY TASKS $\ldots \ldots \ldots \ldots \ldots \ldots \ldots \ldots \ldots$

3.1 Task 1: Development of Remedial Action Objectives and General Response Actions . . . . . . . . . . . . . . . . 3-1

3.1.1 Development of Remedial Action Objectives . . . . . . . . . . . . . 3-1

3.1.2 Development of General Response Actions . . . . . . . . . . . . . . 3-2

3.2 Task 2: Identification of Remedial Action Technologies and Assembly of Alternatives . . . . . . . . . . . . . . . . . . 3-16

3.3 Task 3: Screening of Remedial Action Alternatives . . . . . . . . . . . 3-17

3.4 Task 4: Performance of Treatability Studies . . . . . . . . . . . . . . . . 3-18

3.5 Task 5: Detailed Analysis of Alternatives . . . . . . . . . . . . . . . . . 3-19

3.5.1 Subtask 5.1: Detailed Development of Remaining

Alternatives . . . . . . . . . . . . . . . . . . 3-19

3.5.2 Subtask 5.2: Evaluation of Alternatives against

Regulatory Criteria ..................... 3-20

3.6 Task 6: Cost Analysis . . . . . . . . . . . . . . . . . $3-22$

3.6.1 Subtask 6.1: Capital Costs ................... 3-22

3.6.2 Subtask 6.2: Operating and Maintenance Costs . . . . . . . . 3-23

3.6.3 Subtask 6.3: Present-Worth Analysis . . . . . . . . . . . . . 3-23

3.6.4 Subtask 6.4: Sensitivity Analysis . . . . . . . . . . . . 3-23

3.6.5 Subtask 6.5: Cost Analysis Summary . . . . . . . . . . . . 3-24

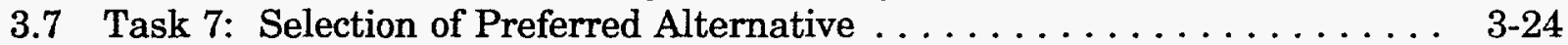

3.8 Task 8: Report Preparation . . . . . . . . . . . . . . . . . . 3-24

4 REPORT PREPARATION $\ldots \ldots \ldots \ldots \ldots \ldots \ldots \ldots \ldots \ldots \ldots \ldots \ldots$. . . . .

4.1 Draft Feasibility Study Report $\ldots \ldots \ldots \ldots \ldots \ldots \ldots \ldots \ldots \ldots \ldots \ldots$ 4 $\ldots \ldots \ldots$

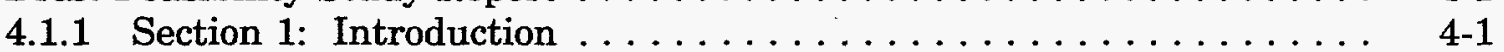

4.1.2 Section 2: Site Background . . . . . . . . . . . $\ldots \ldots \ldots$ 4-1

4.1.3 Section 3: Remedial Action Objectives ............... 4-1

4.1.4 Section 4: Identification and Screening of Technologies . . . . . . 4-1

4.1.5 Section 5: Development and Screening of Preliminary

Alternatives ...................... 4-1

4.1.6 Section 6: Detailed Analysis of Alternatives . . . . . . . . . . . 4 4-3

4.1.7 Section 7: Comparative Analysis of Alternatives . . . . . . . . . . 4-4

4.2 Other Reports and Communications . . . . . . . . . . . . . . . . . . 4-4

4.2.1 Monthly Progress Reports ...................... 4 4 . .

4.2 .2 Responsiveness Summary . . . . . . . . . . . . . $4-5$

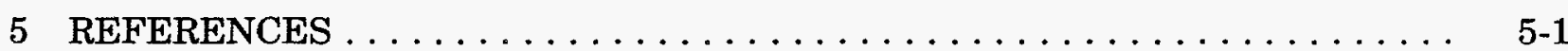

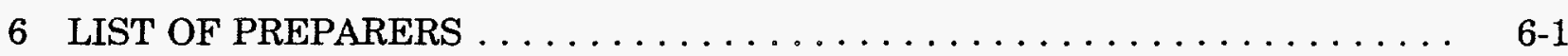

APPENDIX A: Applicable or Relevant and Appropriate Requirements . . . . . A A-1

APPENDIX B: Identification of Potential Areas of Concern at J-Field $\ldots \ldots \ldots$. . B-1 


\section{TABLES}

1.1 Summary of Disposal Activities at J-Field $\ldots \ldots \ldots \ldots \ldots \ldots \ldots$

1.2 Key J-Field RIFS Project Documents $\ldots \ldots \ldots \ldots \ldots \ldots \ldots \ldots \ldots$. . . . . . . .

2.1 Summary of Previous Investigations at J-Field $\ldots \ldots \ldots \ldots \ldots \ldots$. . . . . .

2.2 Analytical Results for Analysis of Soil Samples from the Toxic Burning Pits AOC Main Burning Pits, January 1983 . . . . . . . . . . . . 2-20

2.3 Analytical Results for Analysis of Soil Samples J1-J20 from the

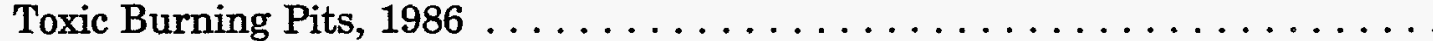

2.4 Analytical Results for Analysis of Soil Samples from the Toxic Burning Pits Area, April $1991 \ldots \ldots \ldots \ldots \ldots \ldots$

2.5 Analytical Results for Target Compound List Analytes in Selected Soil Samples from the Toxic Burning Pits, $1992 \ldots \ldots \ldots \ldots \ldots \ldots$

2.6 Analytical Results for Target Analyte List Analytes in Selected Soil Samples from the Toxic Burning Pits, $1992 \ldots \ldots \ldots \ldots \ldots$. . . .

2.7 Analytical Results for Surface Water Samples from the Toxic Burning Pits Area, $1986 \ldots \ldots \ldots \ldots \ldots \ldots \ldots$

2.8 Analytical Results for Groundwater from the P-Series Monitoring Wells, 1986

2.9 Analytical Results for Selected Inorganic Compounds, TOC, and Metals in Groundwater from the Toxic Burning Pits, $1990 \ldots \ldots \ldots \ldots$. . . . . . . . . .

2.10 Analytical Results for Selected VOCs in Groundwater from the Toxic Burning Pits Area, $1990 \ldots \ldots \ldots \ldots \ldots \ldots \ldots \ldots$

2.11 Analytical Results for Organosulfur and Explosives-Related Compounds in Groundwater from the Toxic Burning Pits Area, 1990

2.12 Analytical Results for Selected VOCs in Groundwater Samples from the Toxic Burning Pits Area, $1992 \ldots \ldots \ldots \ldots \ldots \ldots \ldots$

2.13 Concentrations of Chemical Parameters in Soil from the White Phosphorus Pits at J-Field

2.14 Analytical Results for Soil Samples J31 and J32 from the White Phosphorus Pits, 1986

2.15 Analytical Results for Soil Samples from the White Phosphorus Pits Area, April 1991 


\section{TABLES (Cont.)}

2.16 Analytical Results for TCL and TAL Analytes in Selected Soil

Samples from the White Phosphorus Pits, $1992 \ldots \ldots \ldots \ldots \ldots \ldots \ldots$ 2-50

2.17 Analytical Results for Surface Water Samples from the White Phosphorus Pits Area, $1986 \ldots \ldots \ldots \ldots \ldots \ldots \ldots \ldots \ldots \ldots . \ldots \ldots 2-52$

2.18 Analytical Results for Soil Samples from the Riot Control

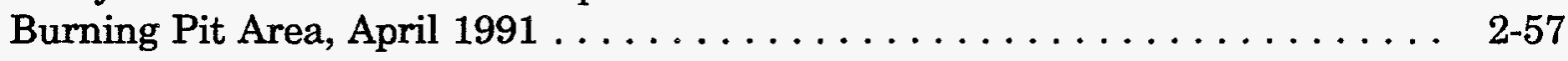

2.19 Analytical Results for TCL Analytes in Selected Soil Samples from the Riot Control Burning Pit Area, $1992 \ldots \ldots \ldots \ldots \ldots \ldots \ldots \ldots \ldots .2-59$

2.20 Analytical Results for TAL Analytes in Selected Soil Samples from the Riot Control Burning Pit Area, $1992 \ldots \ldots \ldots \ldots \ldots \ldots \ldots \ldots \ldots \ldots$ 2-61

2.21 Environmental Media of Concern or Potential Concern at the J-Field Sites

2.22 Preliminary Identification of Contaminants of Potential Concern for the Toxic Burning Pits at J-Field . . . . . . . . . . . . . . . .

2.23 Preliminary Identification of Contaminants of Potential Concern at the White Phosphorus Burning Pits and Other J-Field Sites

2.24 Federal Water Quality Criteria, Standards, and Guidelines for Contaminants of Potential Concern at J-Field

2.25 Atmospheric Criteria for Chemical Warfare Agents that Are Contaminants of Potential Concern at J-Field

3.1 General Response Actions and Technology Types for Soil and Sediment . . . . 3-3

3.2 General Response Actions and Technology Types for Groundwater . . . . . . 3-8

3.3 General Response Actions and Technology Types for Surface Water . . . . . . 3-12

3.4 Site Characteristics That May Affect Response Actions $\ldots \ldots \ldots \ldots \ldots$ 3-16

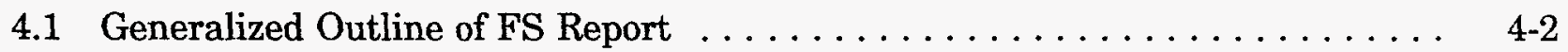

A.1 State Regulations and To-Be-Considereds for J-Field $\ldots \ldots \ldots \ldots \ldots \ldots$ A-3

A.2 Federal Regulations and To-Be-Considereds for J-Field - Potential Contaminant-Specific Requirements . . . . . . . . A-10

A.3 Federal Regulations and To-Be-Considereds for J-Field - Potential Location-Specific Requirements 


\section{TABLES (Cont.)}

A.4 Federal Regulations and To-Be-Considereds for

J-Field - Potential Action-Specific Requirements

\section{FIGURES}

1.1 Location of J-Field in the Edgewood Area at APG $\ldots \ldots \ldots \ldots \ldots \ldots \ldots$

1.2 Location of J-Field and Major Associated Features

on the Gunpowder Neck Peninsula . . . . . . . . . . . . . . . . . 1-4

1.3 Locations of Areas of Concern and Principal Site

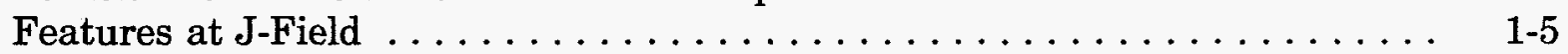

1.4 The Phased RL/FS Process $\ldots \ldots \ldots \ldots \ldots \ldots \ldots \ldots \ldots \ldots \ldots \ldots \ldots$

2.1 Topography of the J-Field Area $\ldots \ldots \ldots \ldots \ldots \ldots \ldots \ldots \ldots \ldots \ldots .2-2$

2.2 Locations of Woods, Marshes, Ponds, Open Fields,

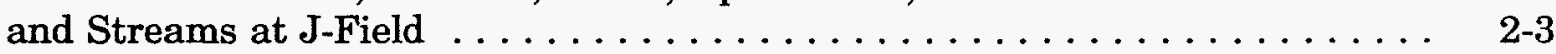

2.3 Groundwater Flow in the Surficial Aquifer, November $1989 \ldots \ldots \ldots \ldots 2-5$

2.4 Relative Contours for All Soil-Gas Parameters at the

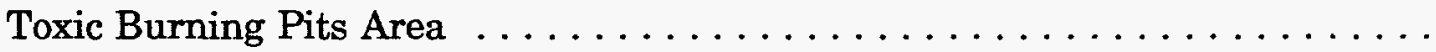

2.5 Relative Contours for Alkanes in Soil Gas

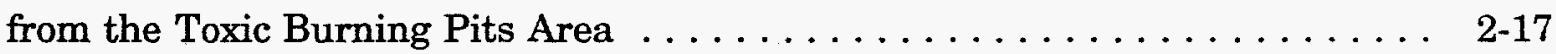

2.6 Relative Contours for Combined TRCLE and TCLEE

at the Toxic Burning Pits Area $\ldots \ldots \ldots \ldots \ldots \ldots \ldots \ldots \ldots \ldots \ldots \ldots \ldots \ldots \ldots .18$

2.7 Relative Contours for Heavy Aromatics in Soil Gas

from the Toxic Burning Pits Area $. . . \ldots \ldots \ldots \ldots \ldots \ldots . . . \ldots \ldots$

2.8 Locations in the Toxic Burning Pits Area where Surface Soil and Surface Water Samples Were Collected during the 1986 RCRA Facility Assessment $\ldots \ldots \ldots \ldots \ldots \ldots \ldots \ldots \ldots$

2.9 Locations where Soil Samples Were Collected by the USGS in $1991 \ldots \ldots$ 2-24

2.10 Locations of Soil Sampling Conducted by Weston in 1992 in the Toxic Burning Pits AOC . . . . . . . . $\ldots \ldots \ldots \ldots .26$

2.11 Locations of Surface Water Samples Collected at J-Field in $1988 \ldots \ldots \ldots \ldots$ 2-31 


\section{FIGURES (Cont.)}

2.12 Locations of Surface Water and Sediment Samples Collected at J-Field in $1992 \ldots \ldots \ldots \ldots \ldots \ldots \ldots \ldots \ldots \ldots$ 2-33

2.13 Locations of All Wells Installed at J-Field $\ldots \ldots \ldots \ldots \ldots \ldots \ldots \ldots \ldots . \ldots \ldots$

2.14 Contours of TRCLE Concentrations in the Surficial Aquifer $\ldots \ldots \ldots \ldots 2-39$

2.15 Relative Flux Contours for TCLEE at the White Phosphorus Pits . . . . . 2-44

2.16 Locations of Soil Borings at the White Phosphorus Pits $\ldots \ldots \ldots \ldots \ldots$ 2-45

2.17 Locations of Surface Soil and Surface Water Samples in the White Phosphorus Pits Area $\ldots \ldots \ldots \ldots \ldots \ldots \ldots \ldots .2-47$

2.18 Relative Flux Contours of Heavy Aromatics at the Riot

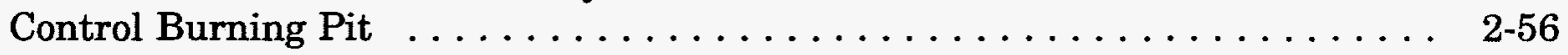

2.19 Locations of Soil Samples Collected by Weston in 1992 from the Riot Control Burning Pit $\ldots \ldots \ldots \ldots \ldots \ldots \ldots \ldots \ldots \ldots .2-58$

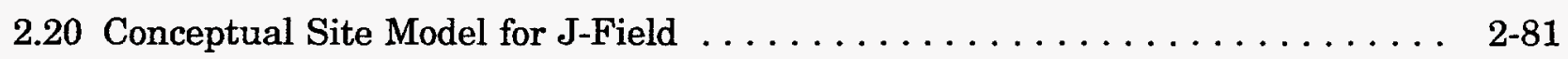

B.1 Locations of PAOCs at J-Field $\ldots \ldots \ldots \ldots \ldots \ldots \ldots \ldots \ldots \ldots \ldots \ldots \ldots \ldots$ 


\section{FOREWORD}

This document presents the Work Plan for the Feasibility Study for Remedial Action to be conducted as part of a remedial investigation/feasibility study (RI/FS) to be carried out at J-Field, Aberdeen Proving Ground, Maryland, pursuant to the Comprehensive Environmental Response, Compensation, and Liability Act (CERCLA), as amended. The RI/FS is to be conducted for the U.S. Army under the direction of the Directorate of Safety, Health, and Environment, Aberdeen Proving Ground. This report is one in a series of documents being prepared to define the plans for RI/FS activities at J-Field. Other documents in this series include a Remedial Investigation Work Plan (Benioff et al. 1995a); a Field Sampling Plan (Benioff et al. 1995b); a Quality Assurance Project Plan (Prasad et al. 1995); a Work Plan for the Focused Feasibility Study of the Toxic Burning Pits Area (Biang et al. 1995); and a Work Plan for Conducting an Ecological Risk Assessment (Hlohowskyj et al. 1995). 


\section{NOTATION}

The following is a list of abbreviations and acronyms, chemicals, and units of measure used in this document. Some acronyms used only in tables are defined in those tables.

\section{ABBREVIATIONS AND ACRONYMS}

\begin{tabular}{|c|c|}
\hline $\begin{array}{l}\text { AEC } \\
\text { ANL } \\
\text { AOC } \\
\text { APG } \\
\text { ARAR }\end{array}$ & $\begin{array}{l}\text { U.S. Army Environmental Center } \\
\text { Argonne National Laboratory } \\
\text { area of concern } \\
\text { Aberdeen Proving Ground } \\
\text { applicable or relevant and appropriate requirement }\end{array}$ \\
\hline CERCLA & $\begin{array}{l}\text { Comprehensive Environmental Response, Compensation, and } \\
\text { Liability Act (as amended) }\end{array}$ \\
\hline CFR & Code of Federal Regulations \\
\hline $\mathrm{COE}$ & U.S. Army Corps of Engineers \\
\hline $\begin{array}{l}\text { COMAR } \\
\text { CWA }\end{array}$ & Code of Maryland Regulations \\
\hline DQO & data quality objective \\
\hline $\begin{array}{l}\text { EMD } \\
\text { EP }\end{array}$ & $\begin{array}{l}\text { Environmental Management Division (Aberdeen Proving Ground) } \\
\text { extraction procedure }\end{array}$ \\
\hline EPA & U.S. Environmental Protection Agency \\
\hline ERA & ecological risk assessment \\
\hline ERT & emergency response team \\
\hline FFS & focused feasibility study \\
\hline FR & Federal Register \\
\hline FS & feasibility study \\
\hline FSP & Field Sampling Plan \\
\hline FWQC & federal water quality criterion \\
\hline $\mathrm{HE}$ & high explosives \\
\hline IRDMS & Installation Restoration Data Management System \\
\hline LDR & land disposal restriction \\
\hline MCL & maximum contaminant level \\
\hline MDE & Maryland Department of the Environment \\
\hline MSL & mean sea level \\
\hline NCP & National Contingency Plan \\
\hline ND & not detected $\ldots$ \\
\hline NPL & National Priorities List \\
\hline
\end{tabular}




$\begin{array}{ll}\text { OB } & \text { open burning } \\ \text { OD } & \text { open detonation } \\ \text { OSHA } & \text { Occupational Safety and Health Administration } \\ \text { PAOC } & \text { potential area of concern } \\ \text { PB } & \begin{array}{l}\text { Prototype Building } \\ \text { preliminary remediation goal }\end{array} \\ \text { PRG } & \text { quality assurance } \\ \text { QA } & \text { quality control } \\ \text { QC } & \text { Riot Control Burning Pit } \\ \text { RCP } & \text { Resource Conservation and Recovery Act (as amended) } \\ \text { RCRA } & \text { RCRA Facility Assessment } \\ \text { RFA } & \text { remedial investigation } \\ \text { RI } & \text { remedial investigation/feasibility study } \\ \text { RI/FS } & \text { record of decision } \\ \text { ROD } & \text { Robins Point Demolition Ground } \\ \text { RPDG } & \text { Robins Point Tower Site } \\ \text { RPTS } & \\ & \text { Sampling and Analysis Plan } \\ \text { SAP } & \text { South Beach Demolition Ground } \\ \text { SBDG } & \text { South Beach Trench } \\ \text { SBT } & \text { solid waste management unit } \\ \text { SWMU } & \text { state water quality standard } \\ \text { SWQS } & \text { Target Analyte List } \\ \text { TAL } & \text { to be considered } \\ \text { TBC } & \text { Toxic Burning Pits } \\ \text { TBP } & \text { Target Compound List } \\ \text { TCL } & \text { total dissolved solids } \\ \text { TDS } & \text { Toxic Substances Control Act } \\ \text { TSCA } & \text { treatment, storage, and disposal } \\ \text { TSD } & \text { U.S. Army Environmental Hygiene Agency } \\ \text { USAEHA } & \text { U.S. Army Toxic and Hazardous Materials Agency } \\ \text { USATHAMA } & \text { U.S. Geological Survey } \\ \text { USGS } & \text { unexploded ordnance } \\ \text { UXO } & \text { White Phosphorus Burning Pits } \\ \text { WPP } & \end{array}$

\section{CHEMICAL SYMBOLS AND ABBREVIATIONS}

BNA base neutral and acid extractable organic compounds

C2H3CL vinyl chloride

C6H6 benzene

CHCL3 chloroform

CK cyanogen chloride 
chloroacetophenone

CS

o-chlorobenzylidene malononitrile

DANC

DCE

11DCE

12DCE

trans-12DCE

DDD

DDE

DDT

DM

DNT

FM

FS

GA

GB

GD

GF

HMX

MIBK

$\mathrm{PAH}$

PCB

PETN

PWP

RDX

TCE

111TCE

112TCE

TCLEA

TCLEE

TKN

TNT

TOC

TOX

TRCLE

VOC

$\mathrm{VX}$

WP decontaminating agent, noncorrosive

dichloroethylene

1,1-dichloroethylene

1,2-dichloroethylene

trans-1,2-dichloroethylene

dichlorodiphenyldichloroethane

dichlorodiphenyldichloroethylene

dichlorodiphenyltrichloroethane

adamsite

dinitrotoluene

titanium tetrachloride

sulfur trioxide/chlorosulfonic acid

$o$-ethyl- $N, N$-dimethylphosphoramidacyanidate (tabun), a nerve agent

isopropyl methylphosphonofluoridate (sarin), a nerve agent

pinacolyl methylphosphonofluoridate (soman), a nerve agent

cyclohexylmethylphosphonofluoridate, a nerve agent

cyclotetramethylenetetranitramine

methyl isobutyl ketone

polyaromatic hydrocarbon

polychlorinated biphenyl

penta-erythritol tetranitrate

plasticized white phosphorus

hexahydro-1,3,5-trinitro-1,3,5-triazine

trichloroethane

1,1,1-trichloroethane

1,1,2-trichloroethane

1,1,2,2-tetrachloroethane

tetrachloroethylene

total Kjeldahl nitrogen

trinitrotoluene

total organic carbon

total organic halogen

trichloroethylene

volatile organic compound

methylphosphonothioic acid =o-ethyl $S$-(2-diisopropylaminoethyl

methylphosphonothioate), a nerve agent

white phosphorus 


\section{UNITS OF MEASURE}

$\begin{array}{ll}{ }^{\circ} \mathrm{C} & \text { degree(s) Celsius } \\ \mathrm{Ci} & \text { curie(s) } \\ \mathrm{pCi} & \text { picocurie(s) } \\ \mathrm{d} & \text { day(s) } \\ { }^{\circ} \mathrm{F} & \text { degree(s) Fahrenheit } \\ \mathrm{ft} & \text { foot (feet) } \\ \mathrm{ft}^{2} & \text { square foot (feet) } \\ \mathrm{g} & \text { gram(s) } \\ \mathrm{kg} & \text { kilogram(s) } \\ \mu \mathrm{g} & \text { microgram(s) } \\ \mathrm{mg} & \text { milligram(s) } \\ \mathrm{h} & \text { hour(s) } \\ \mathrm{in} . & \text { inch(es) } \\ \mathrm{L} & \text { liter(s) } \\ \mathrm{lb} & \text { pound(s) } \\ \mathrm{m} & \text { meter(s) } \\ \mathrm{mi} & \text { mile(s) } \\ \mathrm{ppb} & \text { part(s) per billion } \\ \mathrm{ppm} & \text { part(s) per million }\end{array}$




\section{INTRODUCTION}

\subsection{BACKGROUND}

The Environmental Management Division (EMD) of Aberdeen Proving Ground (APG), Maryland, is conducting a remedial investigation and feasibility study (RI/FS) of the J-Field area at APG pursuant to the Comprehensive Environmental Response, Compensation, and Liability Act (CERCLA), as amended. J-Field is within the Edgewood Area of APG in Harford County, Maryland (Figure 1.1). Since World War II, activities in the Edgewood Area have included the development, manufacture, testing, and destruction of chemical agents and munitions. These materials were destroyed at $J$-Field by open burning ${ }^{1}$ and open detonation (OB/OD).

Considerable archival information about J-Field exists as a result of efforts by APG staff to characterize the hazards associated with the site. Contamination of J-Field was first detected during an environmental survey of the Edgewood Area conducted in 1977 and 1978 by the U.S. Army Toxic and Hazardous Materials Agency (USATHAMA) (predecessor to the U.S. Army Environmental Center [AEC]). As part of a subsequent USATHAMA environmental survey, 11 wells were installed and sampled at J-Field. Contamination at J-Field was also detected during a munitions disposal survey conducted by Princeton Aqua Science in 1983. The Princeton Aqua Science investigation involved the installation and sampling of nine wells and the collection and analysis of surficial and deep composite soil samples. In 1986, a Resource Conservation and Recovery Act (RCRA) permit (MD3-21-002-1355) requiring a basewide RCRA Facility Assessment (RFA) and a hydrogeologic assessment of J-Field was issued by the U.S. Environmental Protection Agency (EPA). In 1987, the U.S. Geological Survey (USGS) began a two-phased hydrogeologic assessment in which data were collected to model groundwater flow at J-Field. Soil-gas investigations were conducted, several well clusters were installed, a groundwater flow model was developed, and groundwater and surface water monitoring programs were established that continue today.

While APG was pursuing the investigation of J-Field under RCRA corrective action, the Edgewood Area was added to the National Priorities List (NPL) on February 21, 1990. Because of that listing, an RI/FS is required for the entire Edgewood Area pursuant to Modification 2 of the RCRA Permit and a March 1990 Federal Facility Agreement between EPA Region III and the Department of the Army. The corrective action requirements of RCRA have been preempted, and J-Field is being evaluated under CERCLA.

1 Pursuant to Title 40, Code of Federal Regulations (40 CFR), Part 260.10, "open burning" means the combustion of any material without the following characteristics:

(1) Control of combustion air to maintain adequate temperature for efficient combustion,

(2) Containment of the combustion-reaction in an enclosed device to provide sufficient residence time and mixing for complete combustion, and

(3) Control of emission of the gaseous combustion products. 


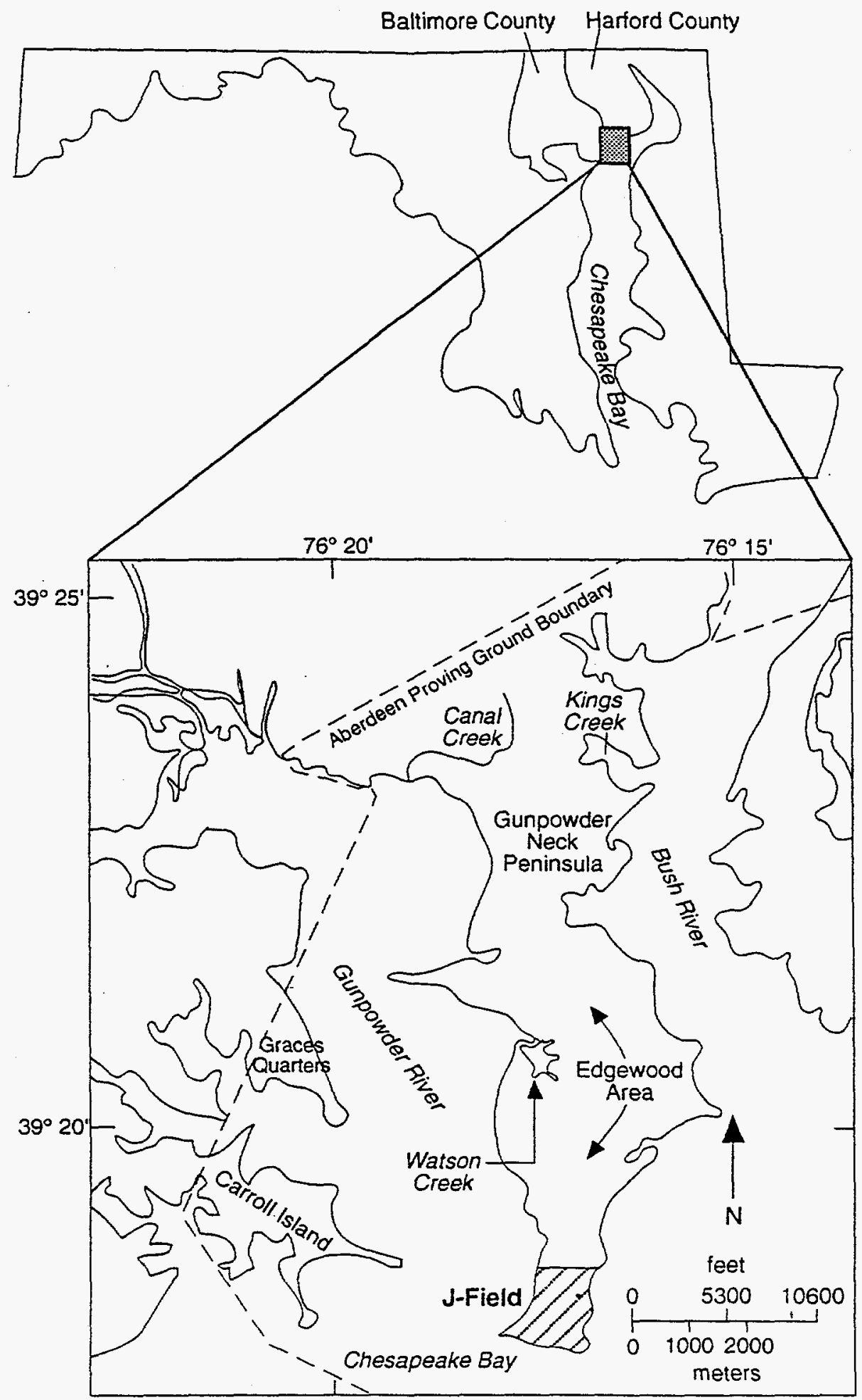

FIGURE 1.1 Location of J-Field in the Edgewood Area at APG (Source: Adapted from Hughes 1993) 
Site characterization activities are currently under way at J-Field. Data gathered from these activities will be used to assess the extent of the contamination problems at various areas of concern (AOCs) within J-Field and the associated risks to human health and the environment. In addition, a focused feasibility study (FFS) is being conducted at the J-Field Toxic Burning Pits (TBP) AOC to develop and evaluate remedial action alternatives to mitigate exposure of human and environmental receptors to contamination source areas within the TBP AOC. The main objective of the FFS is to implement some early remedial action at the TBP AOC.

J-Field is almost flat and is covered by open fields, woods, and nontidal marshes. It encompasses about 460 acres at the southern end of the Gunpowder Neck Peninsula (Figure 1.2). The peninsula is surrounded by tidal estuaries on three sides - Gunpowder River to the west, Chesapeake Bay to the south, and Bush River to the east. For the purposes of the RI/FS, J-Field has been divided into eight geographic areas or features that are designated in this report as AOCs: the Toxic Burning Pits (TBP), the White Phosphorus Burning Pits (WPP), the Riot Control Burning Pit (RCP), the Robins Point Demolition Ground (RPDG), the Robins Point Tower Site (RPTS), the South Beach Demolition Ground (SBDG), the South Beach Trench (SBT), and the Prototype Building (PB) (Figure 1.3). These AOCs correspond to the eight solid waste management units (SWMUs) identified in RCRA Facility Assessment, Edgewood Area, Aberdeen Proving Ground, MD (Nemeth 1989). Several subareas within these AOCs could represent discrete sources of contamination. The AOCs and their associated subareas are as follows:

- Toxic Burning Pits (TBP) AOC

- Main Burning Pits (consisting of a northern burning pit and a southern burning pit)

- Methylphosphonothioic Acid (VX) Burning Pit

- Mustard Burning Pit

- Pushout Area

- $\quad$ Liquid Smoke Disposal Pit

- Demolition Area

- $\quad$ Storage/Unloading Area

- $\quad$ Square Pit

- White Phosphorus Burning Pits (WPP) AOC

- Principal Burning Pits (consisting of a northern burning pit, a southern burning pit, and an associated bermed depression that received runoff from the northern burning pit)

- Pushout Area

- Mounded Areas

- Historic White Phosphorus Disposal Area (located south to southeast of the existing principal burning pits) 


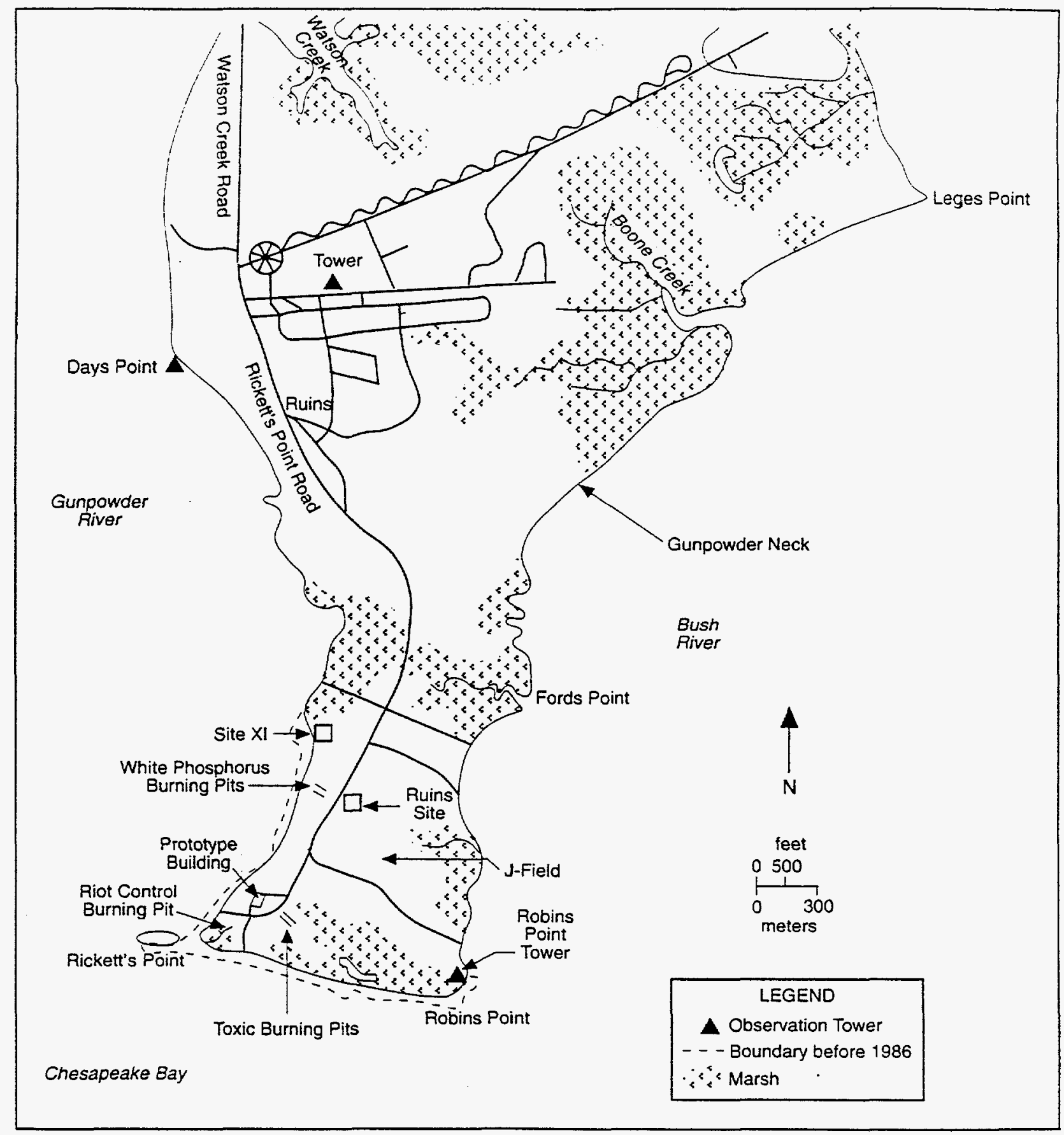

FIGURE 1.2 Location of J-Field and Major Associated Features on the Gunpowder Neck Peninsula (Source: Adapted from Hughes 1993) 


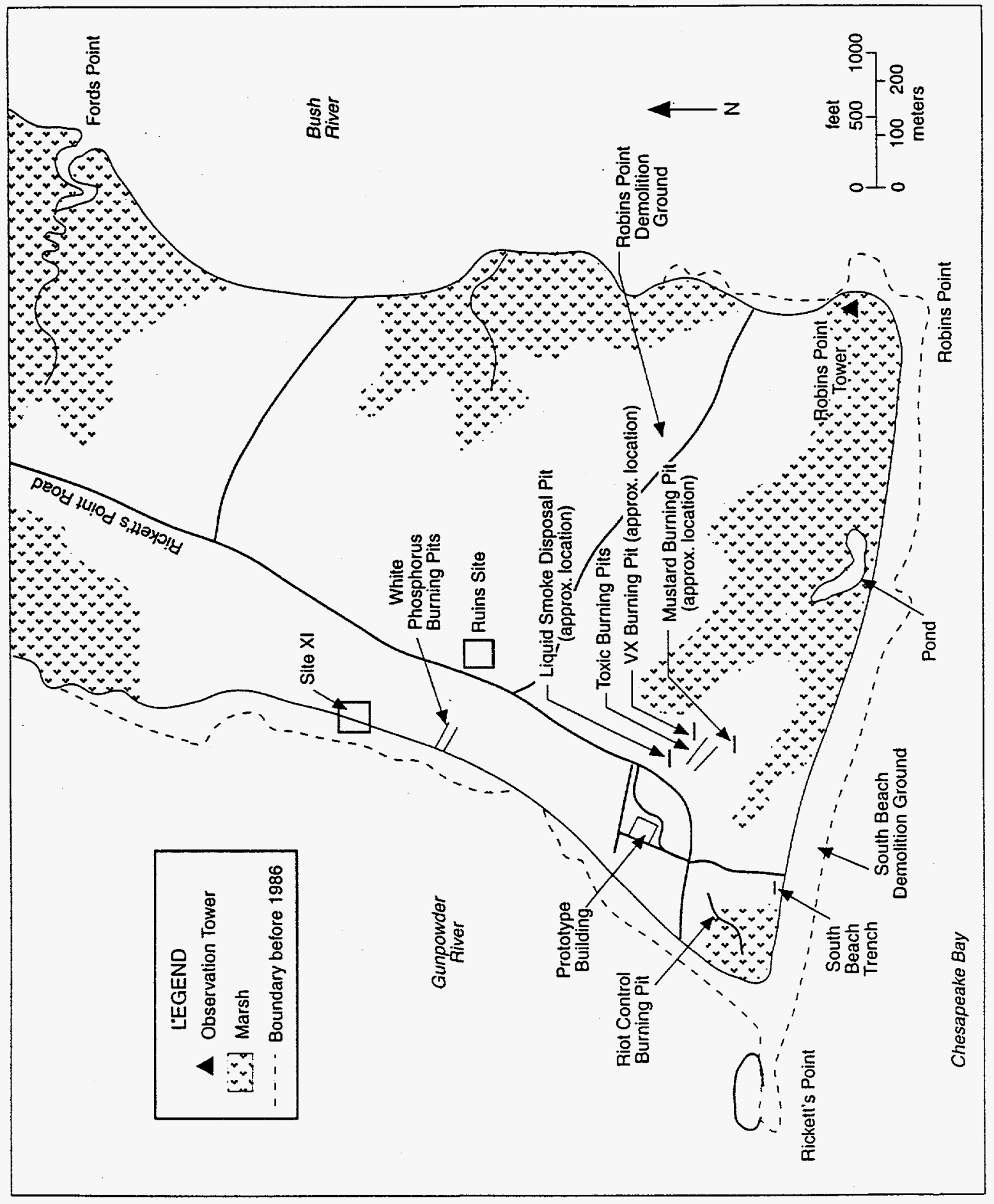

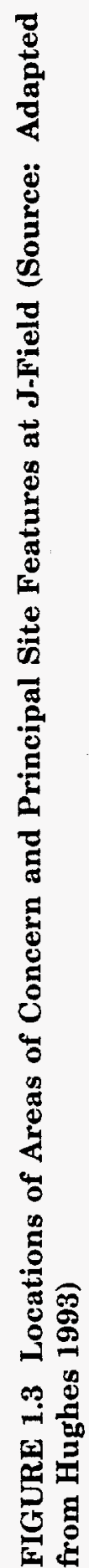


- Riot Control Burning Pit (RCP) AOC

- $\quad$ Burning Pit

- Pushout Area

- Robins Point Demolition Ground (RPDG) AOC

- $\quad$ Active Area

- Inactive Area

- Robins Point Tower Site (RPTS) AOC

- South Beach Trench (SBT) AOC

- South Beach Demolition Ground (SBDG) AOC

- Prototype Building (PB) AOC

Although most of the AOCs are no longer used for OB/OD, a portion of the RPDG is currently active and is operating with interim status under RCRA. A RCRA Part B permit application was submitted in November 1988. An amended permit application is being prepared to update the November 1988 submittal. An open burning pan located $50 \mathrm{~m}$ west of the PB and an open detonation area at the WPP AOC are also being used for emergency disposal operations.

\subsection{SITE HISTORY}

The extent of activities at J-Field before World War II is unknown; however, a terrain map from the 1920s-1930s era indicates that some areas of J-Field were cleared at that time. These cleared areas may have been used for test activities (Nemeth 1989; U.S. Army Corps of Engineers [COE] 1923). During World War II, J-Field was used to test high explosives (HE) and chemical munitions. In addition, chemical agents, chemical wastes, and HE were burned or detonated in open pits or buried under several feet of soil. The depths of the pits were maintained by pushing burned soil and ash out toward the nearby marshes. In the case of the TBP AOC, this procedure moved the edge of the adjacent marsh eastward more than $100 \mathrm{ft}$ (Sonntag 1991). Also during World War II, steel-reinforced structures (such as bunkers, buildings, and slab walls) were built at J-Field to use as targets for conventional munitions.

Available information indicates that chemicals disposed of at $J$-Field have included nerve agents (such as VX), blister agents, riot control agents, white phosphorus, chlorinated solvents, and drummed chemical wastes generated by research laboratories, process laboratories, pilot plants, and machine and maintenance shops. Between 1946 and 1971, limited testing of lethal chemical agents continued at J-Field (Nemeth 1989). Open-air testing of lethal chemical agents stopped in 1969 (Nemeth 1989). Disposal activities at various $\mathrm{J}$-Field locations are summarized in Table 1.1. 
TABLE 1.1 Summary of Disposal Activities at J-Field

\begin{tabular}{|c|c|c|}
\hline Site Name & Period of Use & Activity \\
\hline $\begin{array}{l}\text { Toxic Burning Pits } \\
\text { (originally } \\
5 \text { separate pits; } \\
\text { only } 2 \text { remain) }\end{array}$ & $1940-1980$ & $\begin{array}{l}\text { OB/OD of HE in southeastern portion. } \\
\text { Disposal of HE-filled munitions, nerve } \\
\text { agents, mustard, liquid smoke, } \\
\text { chlorinated solvents, and radioactive } \\
\text { chemicals. }\end{array}$ \\
\hline $\begin{array}{l}\text { White Phosphorus } \\
\text { Burning Pits }\end{array}$ & $\begin{array}{l}\text { Late } 1940 \text { s-1980; } \\
\text { occasional emergency disposal } \\
\text { of white phosphorus }\end{array}$ & $\begin{array}{l}\text { OB/OD of white phosphorus, plasticized } \\
\text { white phosphorus, other chemicals. } \\
\text { Potential for disposal of } \mathrm{CN}^{\mathrm{a}} \text { and } \\
\text { trichloroethylene. }\end{array}$ \\
\hline $\begin{array}{l}\text { Riot Control } \\
\text { Burning Pit Area }\end{array}$ & $\begin{array}{l}\text { Late } 1940 \text { s to early } 1970 \mathrm{~s} \\
\text { riot control agent disposal, } \\
1960 \text { s to early } 1970 \text { s }\end{array}$ & $\begin{array}{l}\mathrm{OB} \text { of chemicals, chemical-filled } \\
\left.\text { munitions, riot control agents (CS, }{ }^{\mathrm{b}} \mathrm{CN}\right) \text {. }\end{array}$ \\
\hline $\begin{array}{l}\text { Robins Point } \\
\text { Demolition Ground }\end{array}$ & Late 1970s-present & $\begin{array}{l}\text { OD of explosive materials, sensitive and } \\
\text { unstable chemicals. }\end{array}$ \\
\hline $\begin{array}{l}\text { South Beach } \\
\text { Demolition Ground }\end{array}$ & Late $1950 \mathrm{~s}-1970 \mathrm{~s}$ & OD of HE. \\
\hline $\begin{array}{l}\text { Prototype Building } \\
\text { Area }\end{array}$ & During World War II & $\begin{array}{l}\text { Stored wastes and HE munitions. } \\
\text { Possible storage of solid wastes in } \\
\text { building or nearby. Building used to test } \\
\text { bombing effects. Periodically used for } \\
\text { storage since World War II. }\end{array}$ \\
\hline $\begin{array}{l}\text { Robins Point Tower } \\
\text { Site }\end{array}$ & Late $1950 \mathrm{~s}-1960 \mathrm{~s}$ & $\begin{array}{l}\text { Potential test burn of radioactively } \\
\text { contaminated wood. }\end{array}$ \\
\hline $\begin{array}{l}\text { South Beach } \\
\text { Trench }\end{array}$ & Late $1950 \mathrm{~s}$ & Unknown. \\
\hline
\end{tabular}

a Chloroacetophenone.

b o-Chlorobenzylidene malononitrile.

Sources: Adapted from Nemeth (1989); EPA and U.S. Department of the Army (1990). 
Procedures for open burning in J-Field pits involved placing 3-4 $\mathrm{ft}$ of wood dunnage in a pit, placing the materials to be burned on top of the dunnage, adding fuel oil, and igniting it. Scrap metal items were removed and reburned in the same manner in a reburn pit. Large metal items were recovered and disposed of as scrap.

Decontamination procedures included the use of a chlorinating agent known as "decontaminating agent, noncorrosive" (DANC). DANC is an organic $N$-chloroamide compound in solution with 1,1,2,2-tetrachloroethane (TCLEA) that was used to decontaminate mustard, Lewisite, and VX. It typically contained 90-95\% (by weight) TCLEA. If recovered scrap materials were decontaminated with DANC in the pit before being removed, the oxidizing agent would degrade. The most significant impact from this procedure would have been the introduction of TCLEA into the environment. Available information indicates that the use of DANC at J-Field was widespread and common (Nemeth 1989).

Disposal of radioactive waste is known to have occurred at J-Field. The TBP area was used for disposal of small amounts of radioactively labeled chemicals. In addition, test burns of contaminated wood wastes, including wood contaminated with radium and strontium-90, may have been conducted at the RPTS (Nemeth 1989).

J-Field has had only limited use since 1980. However, the RPDG and the WPP AOCs are still occasionally used for the destruction of explosives-related materials (Nemeth 1989).

\subsection{OVERVIEW OF THE RIFS PROCESS UNDER CERCLA}

The EPA has developed procedural and documentation requirements for cleanup of hazardous waste sites under CERCLA, as amended by the Superfund Amendments and Reauthorization Act (SARA). The general approach that incorporates these requirements is termed the remedial investigation/feasibility study (RI/FS) process (Figure 1.4). The RI/FS process consists of three primary components:

- The remedial investigation, which presents information on the environmental setting at a site and the nature and extent of contamination;

- The baseline risk assessment, which addresses the environmental fate and transport of contaminants and assesses potential impacts to human health and the environment associated with exposures under current and possible future conditions; and

- The feasibility study, which develops, screens, and evaluates technologies and alternatives for site remediation and identifies potential cleanup criteria. 


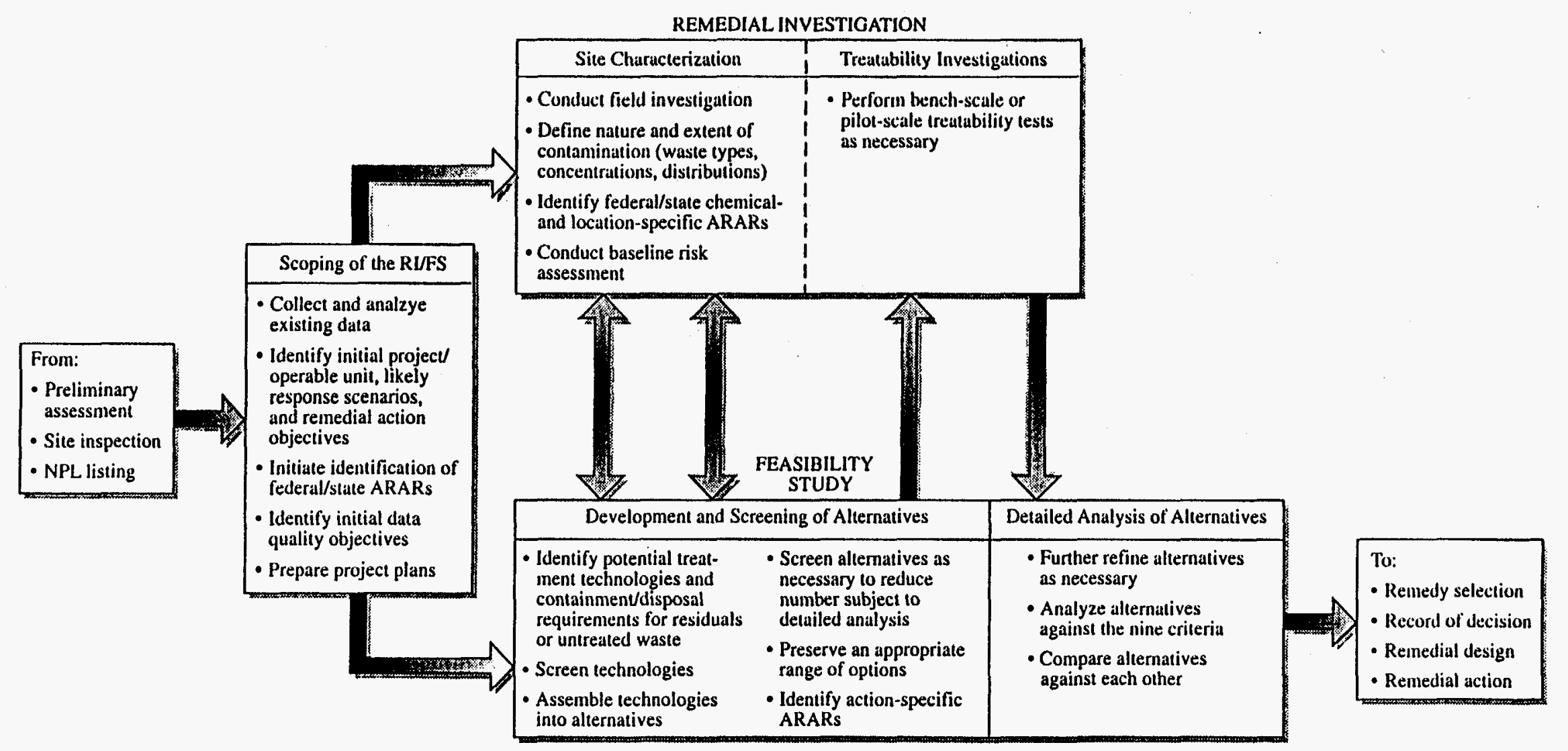

FIGURE 1.4 The Phased RI/FS Process (EPA 1988) 
Table 1.2 lists the key J-Field RI/FS documents that have been prepared to date. All documents have been prepared in accordance with the requirements of both CERCLA and the codified National Contingency Plan (NCP) (EPA 1990). The guidance established by EPA for conducting an RIFS at Superfund sites has also been followed (EPA 1988, 1989a,b).

\subsection{PURPOSE OF THE FEASIBLITY STUDY WORK PLAN}

The purpose of the FS is to gather sufficient information to develop and evaluate alternative remedial actions to address contamination at J-Field in compliance with the NCP, CERCLA, and SARA. This FS Work Plan summarizes existing environmental data for each AOC and outlines the tasks to be performed to evaluate and select remedial technologies. The tasks to be performed will include (1) developing remedial action objectives and identifying response actions to meet these objectives; (2) identifying and screening remedial action technologies on the basis of effectiveness, implementability, and cost; (3) assembling technologies into comprehensive alternatives for J-Field; (4) evaluating, in detail, each alternative against the nine EPA evaluation criteria and comparing the alternatives to identify their respective strengths and weaknesses; and (5) selecting the preferred alternative for each operable unit.

\subsection{REPORT ORGANIZATION}

Section 1 of this FS work plan presents background information and summarizes the purpose and scope of the FS within the context of the RI/FS process. Section 2 summarizes the site background, environmental setting, and previous and ongoing investigations conducted at $\mathrm{J}$-Field. Also included is an overview of available information about the nature and extent of contamination at each $\mathrm{AOC}$, the types of waste present, and the potential pathways of contaminant migration. The environmental setting includes site topography, soils and geology, surface water, groundwater, climate, ecology, and land use/demography. Other site aspects discussed in Section 2 include applicable or relevant and appropriate requirements (ARARs) and other measures to be considered (called "to be considereds," or TBCs), environmental media of concern, contaminants of potential concern, the conceptual site model, preliminary remediation goals, and preliminary identification of operable units.

Section 3 describes the activities for each of the eight main FS tasks. A draft outline of the FS report is presented in Section 4, along with a summary of the contents of each report section. All references cited in this report are listed in Section 5 . Section 6 presents a list of preparers of this document. Appendix A provides tables summarizing preliminary identification of ARARs and TBCs for J-Field. Appendix B discusses potential areas of concern (PAOCs) at J-Field. 
TABLE 1.2 Key J-Field RI/FS Project Documents

\begin{tabular}{|c|c|c|}
\hline Document & Author & Date \\
\hline $\begin{array}{l}\text { Feasibility Study Work Plan for Remedial Action at } \\
\text { J-Field, Aberdeen Proving Ground, Maryland (this } \\
\text { document) }\end{array}$ & Argonne National Laboratory & May 1995 \\
\hline $\begin{array}{l}\text { Draft Focused Feasibility Study Report for the TBP } \\
\text { Area at J-Field, Aberdeen Proving Ground, Maryland }\end{array}$ & Argonne National Laboratory & September 1994 \\
\hline $\begin{array}{l}\text { Remedial Investigation Work Plan for J-Field, } \\
\text { Aberdeen Proving Ground, Maryland }\end{array}$ & Argonne National Laboratory & March 1995 \\
\hline $\begin{array}{l}\text { Remedial Investigation Sampling and Analysis Plan } \\
\text { for J-Field, Aberdeen Proving Ground, Maryland, } \\
\text { Volume 1: Field Sampling Plan }\end{array}$ & Argonne National Laboratory & March 1995 \\
\hline $\begin{array}{l}\text { Remedial Investigation Sampling and Analysis Plan } \\
\text { for J-Field, Aberdeen Proving Ground, Maryland, } \\
\text { Volume 2: Quality Assurance Project Plan }\end{array}$ & Argonne National Laboratory & March 1995 \\
\hline $\begin{array}{l}\text { Work Plan for Focused Feasibility Study of the Toxic } \\
\text { Burning Pits Area at J-Field, Aberdeen Proving } \\
\text { Ground, Maryland }\end{array}$ & Argonne National Laboratory & March 1995 \\
\hline $\begin{array}{l}\text { Risk and Biological Impact Assessment at U.S. Army } \\
\text { Aberdeen Proving Ground, Maryland, Volume 1: } \\
\text { Technical Plan (Final) }\end{array}$ & ICF-Kaiser Engineers & March 1993 \\
\hline $\begin{array}{l}\text { Work Plan for Conducting an Ecological Risk } \\
\text { Assessment at J-Field, Aberdeen Proving Ground, } \\
\text { Maryland }\end{array}$ & Argonne National Laboratory & March 1995 \\
\hline $\begin{array}{l}\text { Baseline Risk Assessment for Eight Selected Study } \\
\text { Areas at Aberdeen Proving Ground, Maryland (Draft) }\end{array}$ & ICF-Kaiser Engineers & January 1991 \\
\hline
\end{tabular}


$1 \cdot 12$ 


\section{SITE BACKGROUND}

\subsection{ENVIRONMENTAL SETTING}

\subsubsection{Surface Features}

J-Field is nearly flat, with a maximum relief of about $10 \mathrm{ft}$. The ground surface slopes gently toward marshy areas or toward Chesapeake Bay and on-site surface water. In some places, wave erosion has formed short, steep cliffs (2-10 ft high) along the shore (Hughes 1993).

Surface water occurs in demolition craters, in marsh areas, and in a few open ponds within the marshes. Between December and May water collects in wooded areas where drainage is poor because the low-permeability soils slow the rate of infiltration. Figure 2.1 shows the overall topography of the site.

\subsubsection{Climate}

The climate in the area of APG is temperate and moderately humid and is moderated by the presence of Chesapeake Bay. The average annual precipitation of $45 \mathrm{in}$. is distributed relatively uniformly during the year. The average annual temperature is about $54^{\circ} \mathrm{F}$ (Nemeth 1989; Hughes 1993).

\subsubsection{Geology and Soils}

The stratigraphy of J-Field consists of Quaternary (Talbot) sediments underlain by Cretaceous (Potomac Group) sediments. The Quaternary sediments constitute a fluvial, estuarine, and marginal marine unit of sand, gravel, and silty clay. The Cretaceous sediments are a sand and clay unit of fluvial origin.

The Quaternary sediments can be divided into three units. The surface unit consists of interbedded sand and clay about 30-40 ft thick; the middle unit is silty, sandy clay and organic matter about 36-107 ft thick; and the base unit is gravelly sand and clay about 13-50 $\mathrm{ft}$ thick. The Cretaceous sediments consist of interbedded layers of fine-grained sand and massive clay. The top of this layer is at a depth of 110-160 ft. Metamorphic bedrock underlies the sediments at depths ranging from 200 to $900 \mathrm{ft}$.

\subsubsection{Surface Water}

The southern and eastern shores of J-Field are covered by an extensive marsh system (Figure 2.2). The marshes may be flooded during storms and very high tides but are 
$76^{\circ} 18^{\prime}$

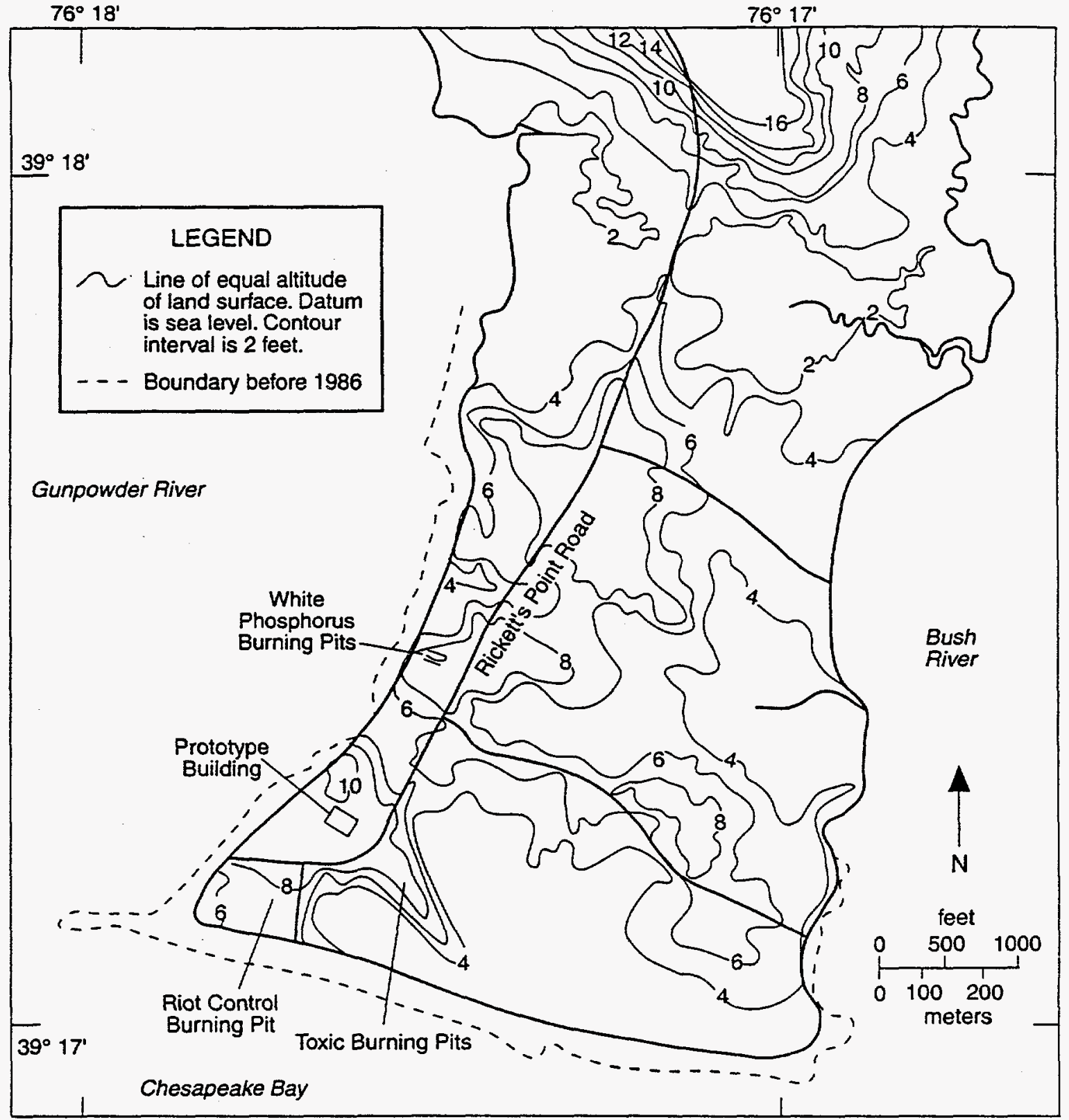

FIGURE 2.1 Topography of the J-Field Area (Source: Adapted from Hughes 1993) 


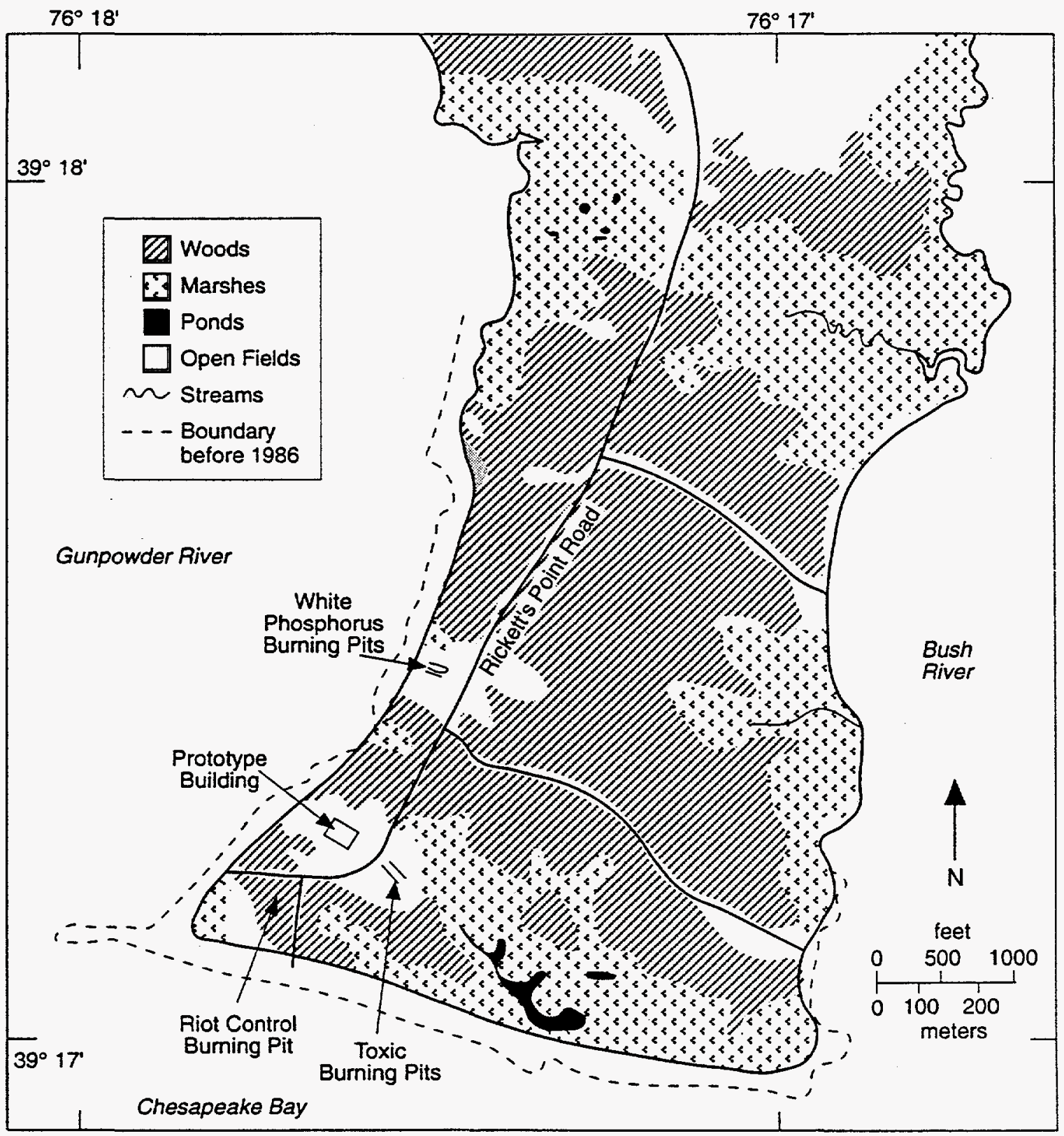

FIGURE 2.2 Locations of Woods, Marshes, Ponds, Open Fields, and Streams at J-Field (Source: Adapted from Hughes 1993) 
not affected by normal tides of 1-2 ft. The water level in the marshes is generally about $2 \mathrm{ft}$ above high tide in Chesapeake Bay. The disposal pits at J-Field originally drained into these marshes or into the Gunpowder and Bush rivers. During the 1970s, drainage from the disposal pits was blocked. Currently, surface water can be 1-2 $\mathrm{ft}$ deep in the TBP and the WPP during the wet season, generally March to June (Hughes 1993). Several ponds and streams are located within the marshy areas of J-Field (Figure 2.2). The largest pond, which is about $5 \mathrm{ft}$ deep, is southeast of the TBP. Two streams on the eastern side of J-Field are the only on-site streams and do not carry much runoff except during storms.

\subsubsection{Groundwater}

Four major hydrologic units have been identified beneath J-Field - the surficial aquifer (in the overlying Talbot layer), the leaky confining unit (in the middle layer), the confined aquifer (in the bottom Talbot unit), and the Potomac Group aquifer. Groundwater flow in these units is described below on the basis of current knowledge of the aquifers. Groundwater is currently being modeled in these units. The model results are not yet available, but will be presented in the RI report with other results of the RI field investigation.

\subsubsection{Surficial Aquifer}

The surficial aquifer consists of interbedded sand and clay and corresponds to the surface unit of the Quaternary (Talbot) sediment; it ranges from 25 to $40 \mathrm{ft}$ thick, with elevations following the surface topography. The steepest hydraulic gradients were found near the TBP and WPP. Because the closest pumping of this aquifer is about $4 \mathrm{mi}$ to the west, the major influences on the flow system are recharge, evapotranspiration, and tidal fluctuations. Recharge is mainly through rainfall, and the system discharges into the marshes and Chesapeake Bay. Some recharge from Chesapeake Bay may occur during droughts (Hughes 1993). Figure 2.3 shows the direction of groundwater flow in the surficial aquifer.

A general downward gradient that occurs between the water table and the leaky confining layer indicates that the leaky confining unit is recharged primarily by the surficial aquifer. During the summer, the direction of vertical flow is reversed at some locations. Groundwater under the marsh and the rivers, which are discharge areas, probably leaks upward from the leaky confining aquifer into the surficial aquifer.

\subsubsection{Leaky Confining Unit}

The leaky confining unit consists of silty, sandy clay and organic matter and corresponds to the middle unit of the Quaternary (Talbot) sediments. Vertical leakage from 


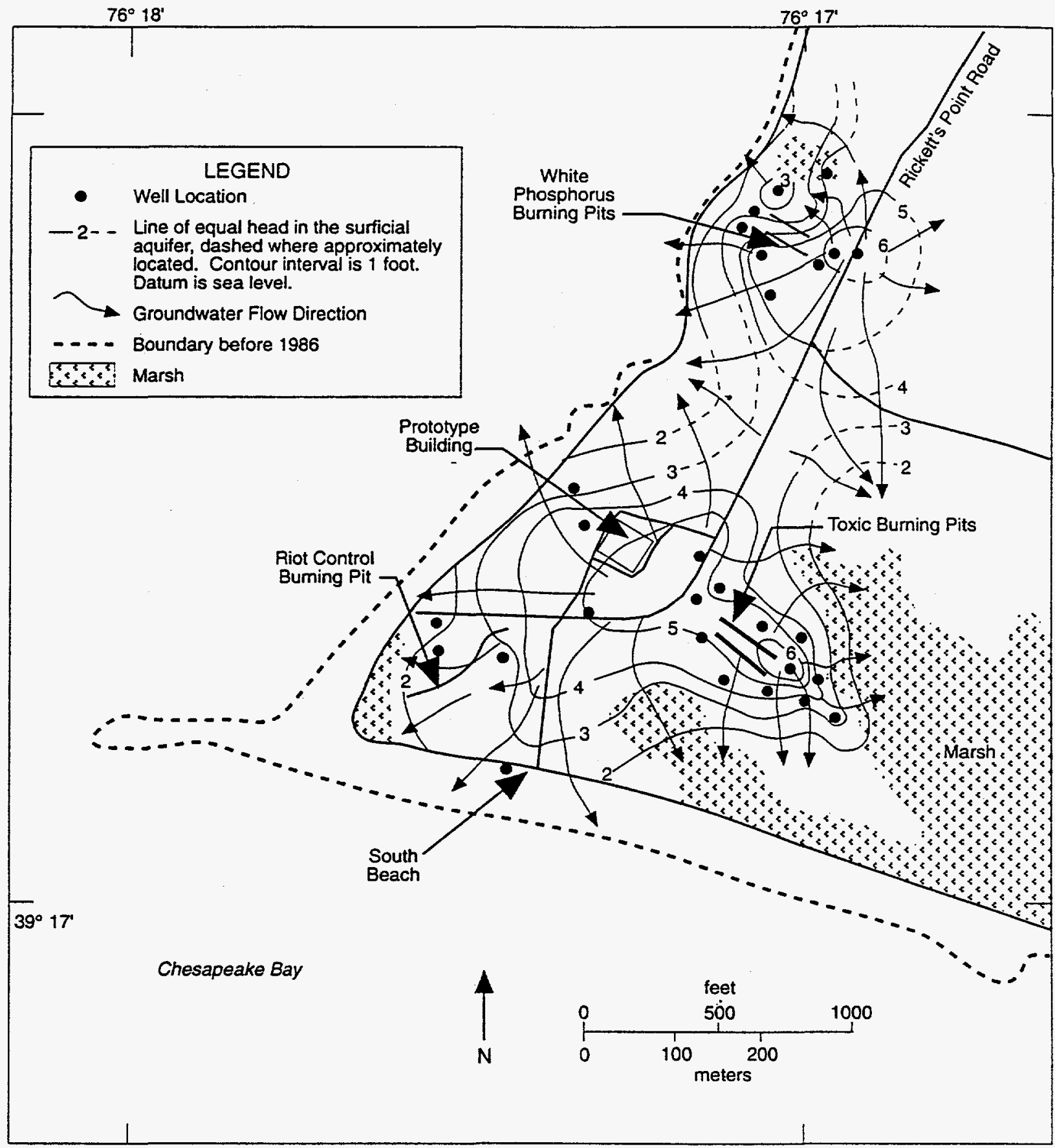

FIGURE 2.3 Groundwater Flow in the Surficial Aquifer, November 1989 (Source: Adapted from Hughes 1993) 
the leaky confining unit to the underlying confined aquifer occurs at all sites beneath J-Field but is probably quite limited offshore. The direction of vertical flow may be reversed in some offshore areas (Hughes 1993).

Lateral flow in the leaky confining unit is generally the same as that of the surficial aquifer. In the western part of the site, the unit is $40 \mathrm{ft}$ thick, with a surface elevation $25 \mathrm{ft}$ below mean sea level (MSL). In the eastern portion of the site, the unit is $107 \mathrm{ft}$ thick and has a surface elevation of $35 \mathrm{ft}$ below MSL. Hydraulic conductivities range from less than 0.01 to $0.20 \mathrm{ft} / \mathrm{d}$, with a median value of $0.05 \mathrm{ft} / \mathrm{d}$ (Hughes 1993).

\subsubsection{Confined Aquifer}

The confined aquifer consists of gravelly sand and clay and corresponds to the base unit of the Quaternary (Talbot) sediments. In the western part of J-Field, the top of the confined aquifer is $60 \mathrm{ft}$ below MSL, and the unit is $50 \mathrm{ft}$ thick. In the southeast, this aquifer dips to a surface elevation of $142 \mathrm{ft}$ below MSL and thins to $15 \mathrm{ft}$ thick. Lateral flow directions are similar to those in the water table; however, the hydraulic head and lateral gradients are very small. Groundwater flows away from the TBP toward the marshes and Chesapeake Bay, and wells show evidence of a tidal influence. Seasonal variations in the flow direction of the confined aquifer occur for short periods during the summer (Hughes 1993).

\subsubsection{Potomac Group Aquifer}

The Potomac Group aquifer consists of interbedded, fine-grained sand and massive clay. This aquifer corresponds to the Cretaceous (Potomac Group) sediments of fluvial origin. Surface elevations of the Potomac Group aquifer range from $105 \mathrm{ft}$ below MSL in the eastern part of J-Field to $157 \mathrm{ft}$ below MSL in the western part. The thickness of the aquifer is, in general, uncertain but may be up to $800 \mathrm{ft}$. The sediments are underlain by metamorphic bedrock. Insufficient data are available to determine lateral or vertical flow directions or the effects of the seasons and tides on the Potomac Group aquifer (Hughes 1993).

\subsubsection{Ecology}

Gunpowder Neck Peninsula consists primarily of open fields (mowed and unmowed grass), bare ground, and second-growth woods (dominated by maple, oaks, and sweetgum). J-Field supports extensive areas of these second-growth woods and freshwater wetlands (dominated by common reed). A large wetland at the southern end of J-Field (Figure 2.2) supports extensive areas of reed and includes a large area of open water. All wetlands at J-Field are separated from the Chesapeake Bay by beach ridges and thus are not directly influenced by tidal fluctuations except through changes in groundwater levels. A few areas of bare ground are located on the western and eastern sides of J-Field, particularly in the vicinity of disposal pits. Additional freshwater tidal and nontidal wetlands occur along the 
periphery of the Gunpowder Neck Peninsula, outside of J-Field. The peninsula is surrounded by freshwater tidal estuaries - Chesapeake Bay to the south, Gunpowder River to the west, and Bush River to the east.

Both the TBP and the WPP AOCs are in open areas cleared of natural vegetation. The area immediately around each pit consists of mowed grass with weeds typical of disturbed habitats and old fields. The TBP are west of a large wetland at the southern end of J-Field. Some of the burned material from these pits has, over time, been pushed into the wetland. The WPP are very close to the Gunpowder River. In 1986, a berm was constructed to prevent waste material from these pits from entering the river. Such material is now diverted into a wetland approximately $100 \mathrm{~m}$ north of the pits. The RCP has not been used since the early 1970s; therefore, it is presently overgrown with shrubs and reeds. It is likely that runoff from the pit enters an adjacent wetland and the Gunpowder River.

The biota at J-Field have not been surveyed in detail; however, common species are likely to include those typical of other areas of the APG. Mammals likely to be common at J-Field include the muskrat, raccoon, white-tailed deer, short-tailed shrew, and white-footed mouse. Common birds could include great blue heron and spotted sandpiper. Because of its status as a federal endangered species, the bald eagle (known to occur at J-Field) is of ecological and regulatory interest. Composition of the fish communities in the J-Field wetlands has not been determined. Common species in the surrounding estuary include alewife, American shad, Atlantic menhaden, channel catfish, and white perch.

\subsection{BACKGROUND OF J-FIELD AREAS OF CONCERN}

The following sections summarize the past disposal operations conducted at each AOC at J-Field. General descriptions of the hydrology and soils in the vicinity of J-Field are also included. PAOCs are addressed in Appendix B.

\subsubsection{Toxic Burning Pits AOC}

The TBP AOC is located on about 9 acres in the southern portion of J-Field (Figure 1.3). Disposal operations at the TBP area began in the 1940s and have continued until the present. The pits were used most extensively between the late 1940s and the 1960s. Items disposed of included chemical agents, bulk chemical wastes, drummed chemical wastes, $\mathrm{HE}$ (by OB/OD), nerve agents, incapacitating agents (also known as riot control agents), chlorinated solvents, and blister agents (Nemeth 1989).

Information from interviews, sampling, and magnetic surveys indicates that five disposal pits were used at the TBP area. The two existing (or main) burning pits (each covering about $4,500 \mathrm{ft}^{2}$ ) were the pits most actively used for the disposal of various chemical agents and explosives. Three other burning pits, now covered, were used to dispose of VX, dichlorodiethyl sulfide (mustard), and the primary components of liquid smoke - titanium tetrachloride (FM) and sulfur trioxide/chlorosulfonic acid (FS). 
The VX pit and mustard pit are about 100 and $150 \mathrm{ft}$ long, respectively. The liquid smoke disposal pit is fairly small, covering an area of about $24 \mathrm{ft}^{2}$. Liquid smoke was probably disposed of by placing it on the ground and allowing it to vaporize into the atmosphere. HE munitions were also disposed of by detonation in an area along the southeastern edge of the TBP area (Nemeth 1989).

Storage and handling areas have been identified (in aerial photographs) at the upper end of both the VX burning pit and the mustard burning pit. In addition, a square pit approximately $4 \mathrm{ft}$ by $4 \mathrm{ft}$ and $3 \mathrm{ft}$ deep has been identified at the current tree line south of the main burning pits. These storage and handling areas and the pit could be additional sources of contamination in the TBP AOC.

The TBP area is bounded to the northeast by marsh and to the south and southeast by woods and marsh (Nemeth 1989). Because the elevation of the ground surface is highest in the northwestern portion of the TBP area, surface water probably drains toward the southsoutheast into the marsh area. The direction of groundwater flow in the surficial aquifer is probably also toward the marsh. Soils are brownish-yellow silty fine sand at the surface, grading to bluish-gray silty fine sand below a depth of $14 \mathrm{ft}$ (Princeton Aqua Science 1984).

\subsubsection{White Phosphorus Burning Pits AOC}

The WPP AOC is located near the Gunpowder River in the western portion of J-Field (Figure 1.3). The area contains two pits that were used for disposal (by detonation and burning) of white phosphorus (WP), plasticized white phosphorus (PWP), munitions filled with WP, and materials contaminated with WP. After materials were burned and reburned in the pits, debris and soil were pushed out. Some of the materials disposed of at this site probably contained other types of waste in addition to WP. The types and quantities of these other wastes are unknown, although personal interviews indicate that riot control agents may have been disposed of here (Nemeth 1989).

The WPP area has been used as a disposal site since the late 1940s or early 1950 s. Aerial photographs show that in 1951, disposal operations were conducted in the southeastern portion of what is currently the open disposal area. The two existing pits were constructed sometime between 1951 and 1957 (Nemeth 1989).

During the late 1950s, the pits were extended to the Gunpowder River. Pushout from the pits was pushed into the river. In 1986, a ditch was excavated to drain water from the pits. The ditch from the northern pit extends north toward a bermed depression that was constructed to hold the water. The ditch associated with the southern pit ends at what is assumed to be a pushout area. During wet weather, water collects in the pits and the bermed depression, even though surface runoff does not enter the pits (Nemeth 1989; Sonntag 1991). As previously noted, the WPP is considered an active emergency disposal facility. As a result, the existing pits and areas potentially affected by emergency disposal operations have been excluded from the RI/FS and are deferred pending the relocation of emergency disposal operations. However, aerial photograph interpretation indicates that two 
suspect burning areas may have existed northwest and southwest of the WPP and that a storage area may have existed southeast of the WPP. These areas could represent sources of contamination and are not likely affected by current operations. As a result, these areas will be addressed in this FS.

Surface water drainage from the WPP area flowed west into Gunpowder River. The direction of groundwater flow in the surficial aquifer is also probably toward Gunpowder River to the west (Nemeth 1989). Soils are brownish-yellow silty fine sand at the surface, grading to bluish-grey silty fine sand below a depth of $14 \mathrm{ft}$ (Princeton Aqua Science 1984).

\subsubsection{Riot Control Burning Pit AOC}

The RCP AOC is located in a heavily wooded area in the southwestern portion of J-Field (Figure 1.3). Except for a small area in the northeastern part of the site, the area is overgrown with vegetation. About $30 \mathrm{ft}$ of an access road has been eroded, and the presence of several fallen trees about $10 \mathrm{ft}$ offshore indicates that this area is rapidly being eroded by wave action.

Disposal operations in the pit began in the late 1940s and continued until operations at the site ceased in the early 1970s. The area immediately east of the access road to the South Beach was probably part of the site and may have been used for burning operations during the 1950s. A trench was excavated in the area sometime between 1957 and 1960 and was later extended southwest to the Gunpowder River to provide drainage from the pit. Between 1960 and the early 1970s, the trench was used for burning riot control agents, munitions filled with riot control agents, and material contaminated with these agents (Nemeth 1989). The main agent disposed of was the tear agent o-chlorobenzylidene malononitrile (CS); some chloroacetophenone (CN) was also disposed of there (Sonntag 1991).

Surface water drainage from the RCP area flows toward the southwest into a small marsh area and the Gunpowder River. The direction of groundwater flow in the surficial aquifer is probably toward the marsh and Gunpowder River to the west-southwest. Shallow soils are predominantly clayey sandy silt (Nemeth 1989).

\subsubsection{Prototype Building AOC}

The PB AOC is located in the southwestern portion of J-Field, northwest of the TBP area and north of the RCP area (Figure 1.3). The building, constructed during World War II, is an open-sided, three-level reinforced concrete structure. It was originally used for testing the effectiveness of bombs. Since World War II, the PB and the areas to the west and north have been intermittently used for temporary storage of solid waste (Nemeth 1989). Two suspect burning areas have also been identified - one northeast and one west of the $\mathrm{PB}$ - on the basis of a review of archival information. 
The area around the PB is fairly flat; surface water drains primarily west toward a marsh area (Nemeth 1989) but may also flow north-northwest toward the Gunpowder River. The direction of groundwater flow in the surficial aquifer is probably toward Chesapeake Bay. The shallow soils are predominantly silty, clayey sand with greater amounts of clay and silt near the surface (Nemeth 1989).

\subsubsection{South Beach Demolition Ground AOC}

The SBDG AOC was located along the southern beach of J-Field (Figure 1.3). The area was used as a demolition site for HE munitions during the 1960s and 1970s, and possibly during the 1950s (Nemeth 1989). Munitions were detonated either on the surface or under several feet of soil. It is reported that remnants of munitions detonated in this area are currently visible about $100 \mathrm{ft}$ offshore during low tide. At high tide, most of the demolition ground area is 1-2 ft below water. A few demolition craters, which are assumedly remnants of the SBDG operations, are visible just inland from the shoreline and east of the end of Rickett's Point Road.

Surface water from the remnants of the SBDG most likely drains south toward Chesapeake Bay. The direction of groundwater flow in the surficial aquifer is probably toward the bay as well. The nature of the shallow soils in the SBDG is undocumented; however, they are most likely composed of clayey sandy silt, similar to the SBT area.

\subsubsection{South Beach Trench AOC}

The SBT AOC is located near the southern beach of J-Field, southeast of the RCP area (Figure 1.3). The trench, about $75 \mathrm{ft}$ long and $12 \mathrm{ft}$ wide, was excavated between 1957 and 1960. It may have been a borrow pit for nearby demolition activities. Aerial photographs from the 1960s reveal a road leading into and out of the SBT. No information has been found regarding past chemical or hazardous material disposal in this area; however, chemical analyses of soil samples collected from the trench during the RFA showed low levels of chlordane and naphthalene (Nemeth 1989).

Surface water drainage from the SBT is primarily west toward a marsh area (Nemeth 1989), but surface water may also flow south toward Chesapeake Bay. Groundwater in the surficial aquifer probably flows toward Chesapeake Bay. Shallow soils are predominantly clayey sandy silt (Nemeth 1989).

\subsubsection{Robins Point Demolition Ground AOC}

The RPDG AOC is in the eastern portion of J-Field close to the Bush River (Figure 1.3). The site was first used during the late 1970s for the destruction of HE and HE-filled munitions. The site was also reportedly used during the 1980s for destruction of small amounts of sensitive and unstable chemicals by detonation with explosives (Nemeth 1989). 
The original site, now inactive and considered an AOC for the purposes of the RIFS activities, was a small clearing near the edge of the adjacent marsh. In 1985, the clearing was enlarged, and a berm was built on the western edge of the clearing. Later demolition activities occurred in an area west of the berm; the berm prevented surface runoff from entering the marsh (Nemeth 1989). The area west of the berm has remained active and continues to be used for disposal operations.

Before 1985, surface water drainage from the RPDG flowed directly into the adjacent marsh to the east. The berm constructed in 1985 now prevents runoff from directly entering the marsh. However, water that ponds west of the berm seeps through the berm to the inactive portion of the RPDG. Groundwater in the surficial aquifer probably flows to the east toward the marsh. Shallow soils in the RPDG consist predominantly of clayey silt (Nemeth 1989).

\subsubsection{Robins Point Tower Site AOC}

The RPTS AOC is located near Robins Point at the southeastern tip of the Gunpowder Peninsula (Figure 1.3). The wooden observation tower was built between 1957 and 1960. The road connecting Robins Point with Rickett's Point Road has existed since about 1917, when APG became an army installation. However, aerial photographs suggest that the area was not used until the 1950s. The Robins Point area was used for launching and observing rockets (Nemeth 1989).

Around 1959, the Robins Point area may have been used for at least one test burn of wood contaminated with radioactive material (including radium and strontium). According to Nemeth (1989), the test burn was to be conducted in a trench ( $20 \mathrm{ft}$ long, $5 \mathrm{ft}$ wide, and $5 \mathrm{ft}$ deep), with not more than $500 \mathrm{lb}$ of material to be burned in small increments. A 1959 U.S. Army Environmental Hygiene Agency (USAEHA) report recommended that the routine burning of radioactively contaminated materials be conducted in a closed incinerator; correspondence in the USAEHA project file indicates that this recommendation was accepted (Nemeth 1989). The possibility remains, however, that a test burn of radioactively contaminated wood did occur at either the RPDG or the RPTS. Records do not indicate which site was used. However, it is likely that the RPTS was used because the site of the demolition ground was wooded and not yet in use in 1959. In addition, aerial photographs from the 1960s show no roads or open areas at the site of the RPDG.

Surface water from the RPTS probably flows east toward Bush River and south toward the adjacent marsh. Groundwater in the surficial aquifer probably also flows toward Bush River and the marsh. The shallow soils are predominantly sand, with sandy clayey silt near the surface (Nemeth 1989). 


\subsubsection{Other J-Field Sites}

Pursuant to the requests of the Maryland Department of the Environment (MDE), investigative activities have been expanded beyond the eight specified AOCs to include all of J-Field. As a result, a protocol was developed to identify other suspect areas, referred to as PAOCs, on the basis of a review of archival information and walkover surveys. The process used to identify the PAOCs and the sampling activities proposed for the PAOCs are described in Appendix B.

\subsection{PRELIMINARY EVALUATION OF J-FIELD AREAS OF CONCERN}

Several investigations have been conducted at J-Field to characterize contamination from past operations, install monitoring wells, and characterize the estuarine sediments around the peninsula. Table 2.1 provides a chronological summary of these studies. An overview of the results of these studies is presented in the following sections. These sections present data for J-Field that were collected through January 1993. All data corrected during the RI will be presented in technical updates and the RI report.

\subsubsection{Toxic Burning Pits}

\subsubsection{Types of Waste Present}

The TBP were used to dispose of HE-filled munitions, nerve agents, mustard agents, chemical warfare agents (CWAs), decontaminating agents, liquid smoke, chlorinated solvents, and radioactive chemicals. In addition, fuel was used to ignite materials placed in the pits.

\subsubsection{Types of Contaminants Present}

A hydrological assessment of J-Field was carried out in two phases by the USGS. Phase I was conducted from 1987 to 1992 to select locations for establishing monitoring wells at the TBP and WPP areas. It was assumed that the pits and the open burning grounds around them were the primary sources of contamination in the area. The goal of Phase II, conducted in 1992, was to determine the extent of contamination in the area of the TBP, sample the RCP area, and determine if contaminated groundwater was moving into Chesapeake Bay (Hughes 1993). The following subsections discuss the findings relative to the nature and extent of contamination in the TBP area.

\section{Soil Gas}

During Phase I of the hydrological assessment, the USGS sampled 37 locations around the TBP for soil-gas concentrations of trichloroethylene (TRCLE), tetrachloroethylene 
TABLE 2.1 Summary of Previous Investigations at J-Field

\begin{tabular}{|c|c|c|c|}
\hline Field Investigation & Investigator & Date & Objective/Activity \\
\hline $\begin{array}{l}\text { Environmental } \\
\text { Contamination Survey }\end{array}$ & USATHAMA & $1977-1978$ & $\begin{array}{l}\text { Conducted to determine if contamination from past } \\
\text { operations was migrating off-post. Eleven monitoring wells } \\
\text { (TH1-11) were installed in the surficial aquifer }-10 \text { near the } \\
\text { TBP and WPP and } 1 \text { near the Robins Point Tower. Ground- } \\
\text { water samples were collected and analyzed. }\end{array}$ \\
\hline Munitions Disposal Study & $\begin{array}{l}\text { Princeton Aqua } \\
\text { Science }\end{array}$ & 1983 & $\begin{array}{l}\text { Installed nine monitoring wells (P1-9) in the surficial } \\
\text { aquifer - five near the TBP and four near the WPP. } \\
\text { Composite soil samples were collected during drilling of wells. } \\
\text { Soil samples were also collected from the pits in the TBP and } \\
\text { WPP areas. }\end{array}$ \\
\hline $\begin{array}{l}\text { RCRA Facility } \\
\text { Investigation }\end{array}$ & USAEHA & 1986 & $\begin{array}{l}\text { Sampled groundwater from TH and P series wells. Soil } \\
\text { samples also collected in and around the pits in the TBP, } \\
\text { WPP, and RCP areas and near the Prototype Building. A } \\
\text { field radiation survey was also performed. }\end{array}$ \\
\hline $\begin{array}{l}\text { Hydrological Assessment, } \\
\text { Phase I }\end{array}$ & USGS & 1987-1992 & $\begin{array}{l}\text { Drilled exploratory boreholes, collected soil samples, and ran } \\
\text { geophysical logs. Installed } 12 \text { well clusters (JF1-12), each } \\
\text { consisting of } 3 \text { wells screened in the upper portions of the } \\
\text { confined aquifer, the confining unit, and surficial aquifer. } \\
\text { Wells were sampled on a monthly (1987) and quarterly } \\
\text { basis (1989-1992); water-level measurements also taken. } \\
\text { Conducted slug tests. Currently using MODFLOW model to } \\
\text { simulate contaminant pathways in groundwater. A total of } \\
21 \text { surface samples also collected from Gunpowder River and } \\
\text { Chesapeake Bay. Soil and soil-gas samples collected in TBP } \\
\text { and WPP areas. }\end{array}$ \\
\hline
\end{tabular}


TABLE 2.1 (Cont.)

\begin{tabular}{|c|c|c|c|}
\hline Field Investigation & Investigator & Date & Objective/Activity \\
\hline $\begin{array}{l}\text { Characterization and } \\
\text { Interim Remediation }\end{array}$ & $\begin{array}{l}\text { Roy F. Weston, } \\
\text { Inc. }\end{array}$ & 1992 & $\begin{array}{l}\text { Activities included topographic survey of J-Field area; survey } \\
\text { of UXO }{ }^{\mathrm{a}} \text { in each burning pit and along shoreline of WPP and } \\
\text { RCP; construction of access roads; placement of riprap and } \\
\text { gabion structures along WPP and RCP shoreline; removal } \\
\text { and staging of surface material and debris from burning pit } \\
\text { areas; sampling and staging drums from the Prototype } \\
\text { Building; sampling and analysis of soil from the pits and } \\
\text { pushout areas; installation of flood control berms in the pit } \\
\text { areas, where needed; and collection of surface and subsurface } \\
\text { soil samples. }\end{array}$ \\
\hline $\begin{array}{l}\text { Hydrological Assessment- } \\
\text { Phase II }\end{array}$ & USGS & 1992 & $\begin{array}{l}\text { Continued sampling of groundwater, measuring water levels } \\
\text { in all monitoring wells, and slug testing. Four new wells } \\
\text { installed. Collected surface water samples from marsh areas } \\
\text { and estuaries surrounding J-Field, based on thermal imagery } \\
\text { studies conducted by the USGS. }\end{array}$ \\
\hline Sediment Sampling Study & EPA & 1992 & $\begin{array}{l}\text { Conducted a study to characterize the estuarine sediments } \\
\text { around the Gunpowder Neck Peninsula. }\end{array}$ \\
\hline
\end{tabular}

a UXO = unexploded ordnance. 
(TCLEE), alkanes, combined hydrocarbons, and simple aromatics. The relative contours for all contaminants except the alkanes show a broad band of contamination that extends across the eastern end of the pits from the marsh on the north to the marsh on the south (Figure 2.4). The alkanes appear to be limited to the area south of the TBP, and the data suggest a plume of contamination moving into the marsh at the southern edge (Figure 2.5) (Hughes 1993).

Additional soil-gas samples were collected during Phase II from wooded and marshy areas north and south of the TBP and from 15 locations along Chesapeake Bay. Samples were analyzed for combined dichloroethylenes (DCEs) and trichloroethanes (TCEs), combined TRCLEs and TCLEEs, phthalates, and heavy aromatic hydrocarbons (Hughes 1993).

Relative values and contours for concentrations of combined DCE and TCE and of combined TRCLE and TCLEE show a similar distribution, with elevated contamination to the southeast of the TBP. Figure 2.6 shows contours for combined TRCLE and TCLEE. The DCE plus TCE contamination south of the pits is somewhat more extensive, with elevated values extending to the shore of Chesapeake Bay. The concentration contours, when combined with contours from Phase I analyses, suggest that plumes of contaminated groundwater are moving downgradient under the marshes both on the northern and southern sides of the TBP. This hypothesis is supported by the relative contours for heavy aromatics (Figure 2.7), which show locations with more extensive contamination, including along the shore. The data also suggest that contaminated groundwater may be moving beneath, and possibly discharging into, the bay, or that contaminated surface water from the marshes may be moving into shore sediments (Hughes 1993).

\section{Soil}

In 1983, soil samples were collected during the installation of monitoring wells at the TBP. Four composite samples were collected at depth intervals of $5 \mathrm{ft}$. The samples were analyzed for metals, cyanide, phenols, total phosphorus, volatile organic compounds (VOCs), pesticides, polychlorinated biphenyls (PCBs), and herbicides. Some of the results are listed in Table 2.2. The data showed elevated concentrations of lead, zinc, nitrate, and petroleum hydrocarbons in each of the samples. It should be noted that the background samples also contained somewhat elevated concentrations of petroleum hydrocarbons.

During the 1986 RFA (Nemeth 1989), surface soil samples were collected from 20 locations in the TBP and the debris pushout area (Figure 2.8). All of the samples were analyzed for metals, extractable metals, and explosives-related compounds. The results, as summarized in Table 2.3, show that the surface soil in and around the TBP contain elevated levels of metals, especially lead (up to $2.6 \%$ in the pushout area [location 12]); mercury (up to $10.8 \mathrm{mg} / \mathrm{kg}$ in one of the pits [location 8]); and cadmium (16.6 mg/kg at location 20). Samples from locations 7 and 12 exceeded the RCRA extraction procedure (EP) limit of $5.0 \mathrm{mg} / \mathrm{L}$ for lead (40 CFR 261). 


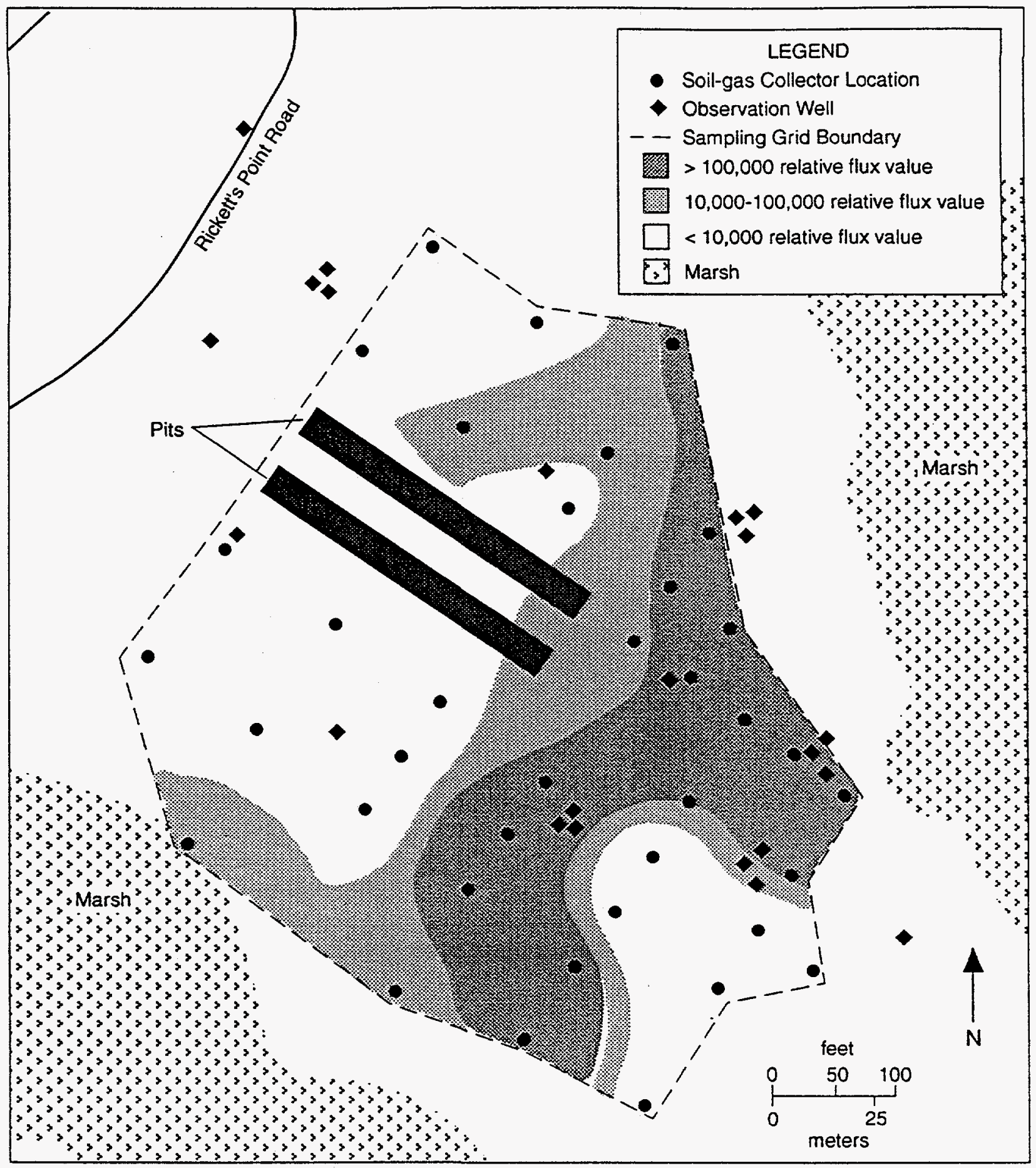

FIGURE 2.4 Relative Contours for All Soil-Gas Parameters (except alkanes) at the Toxic Burning Pits Area (Source: Adapted from Hughes 1993) 


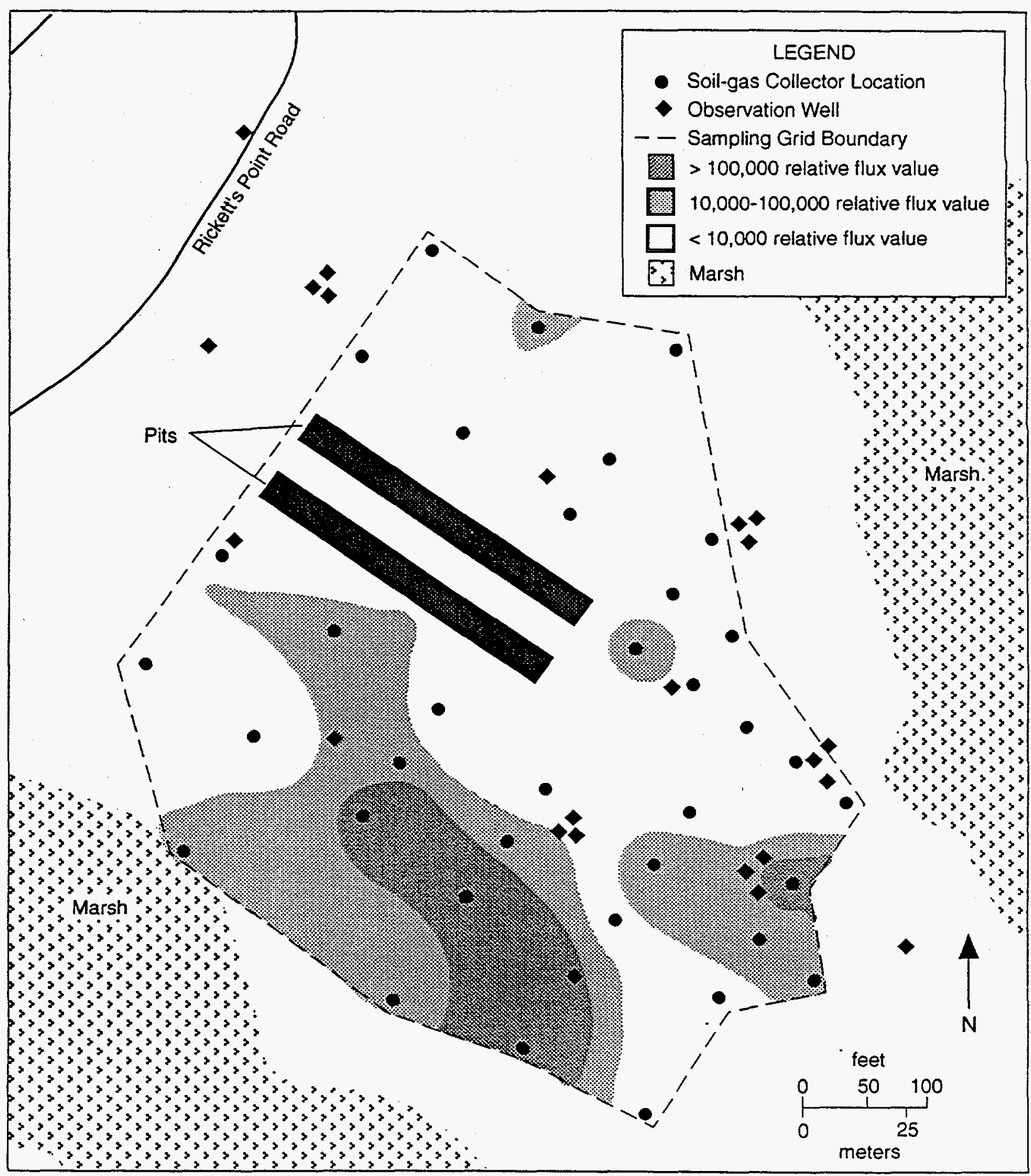

FIGURE 2.5 Relative Contours for Alkanes in Soil Gas from the Toxic Burning Pits Area (Source: Adapted from Hughes 1993) 


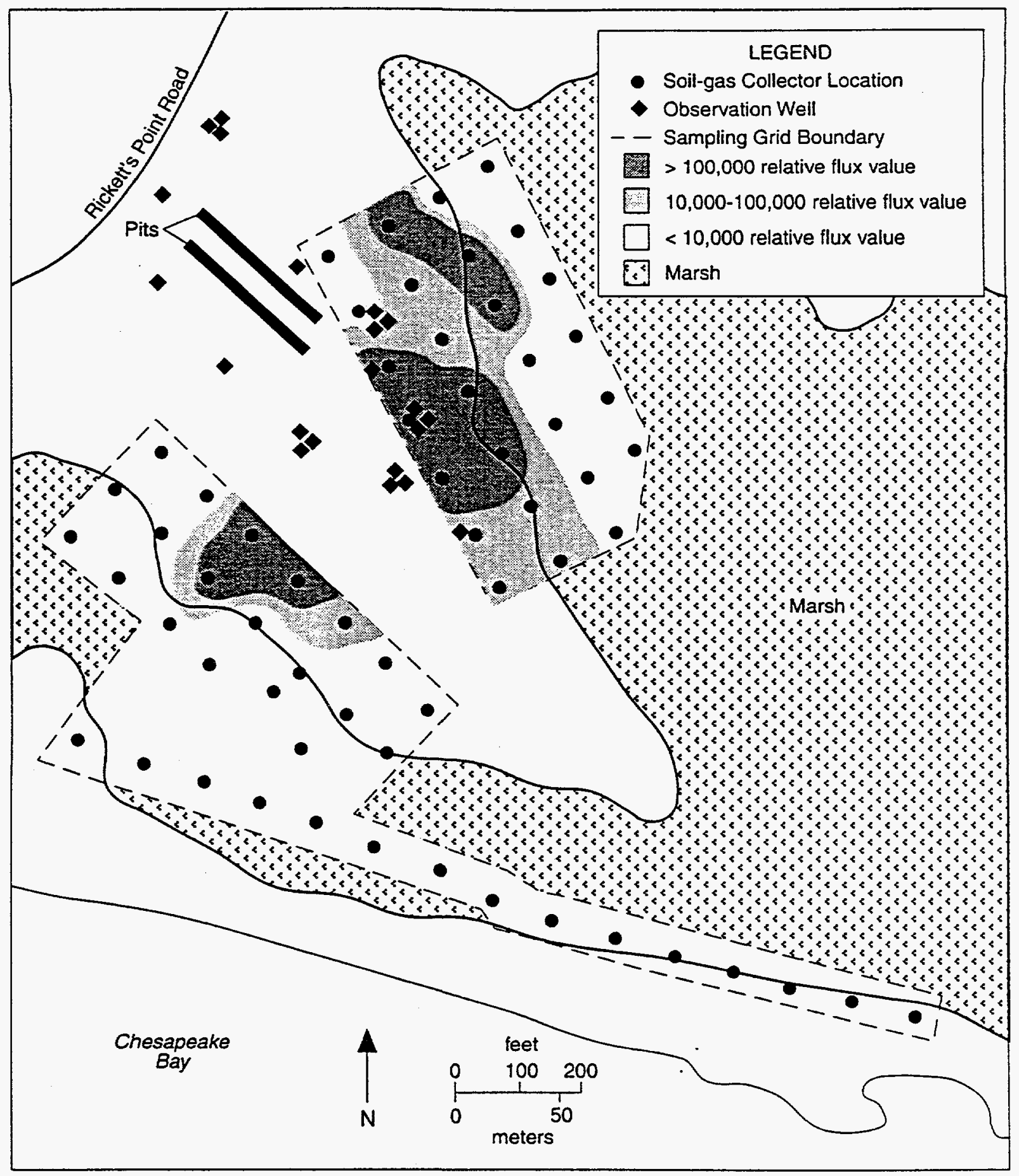

FIGURE 2.6 Relative Contours for Combined TRCLE and TCLEE at the Toxic Burning Pits Area (Source: Adapted from Hughes 1993) 


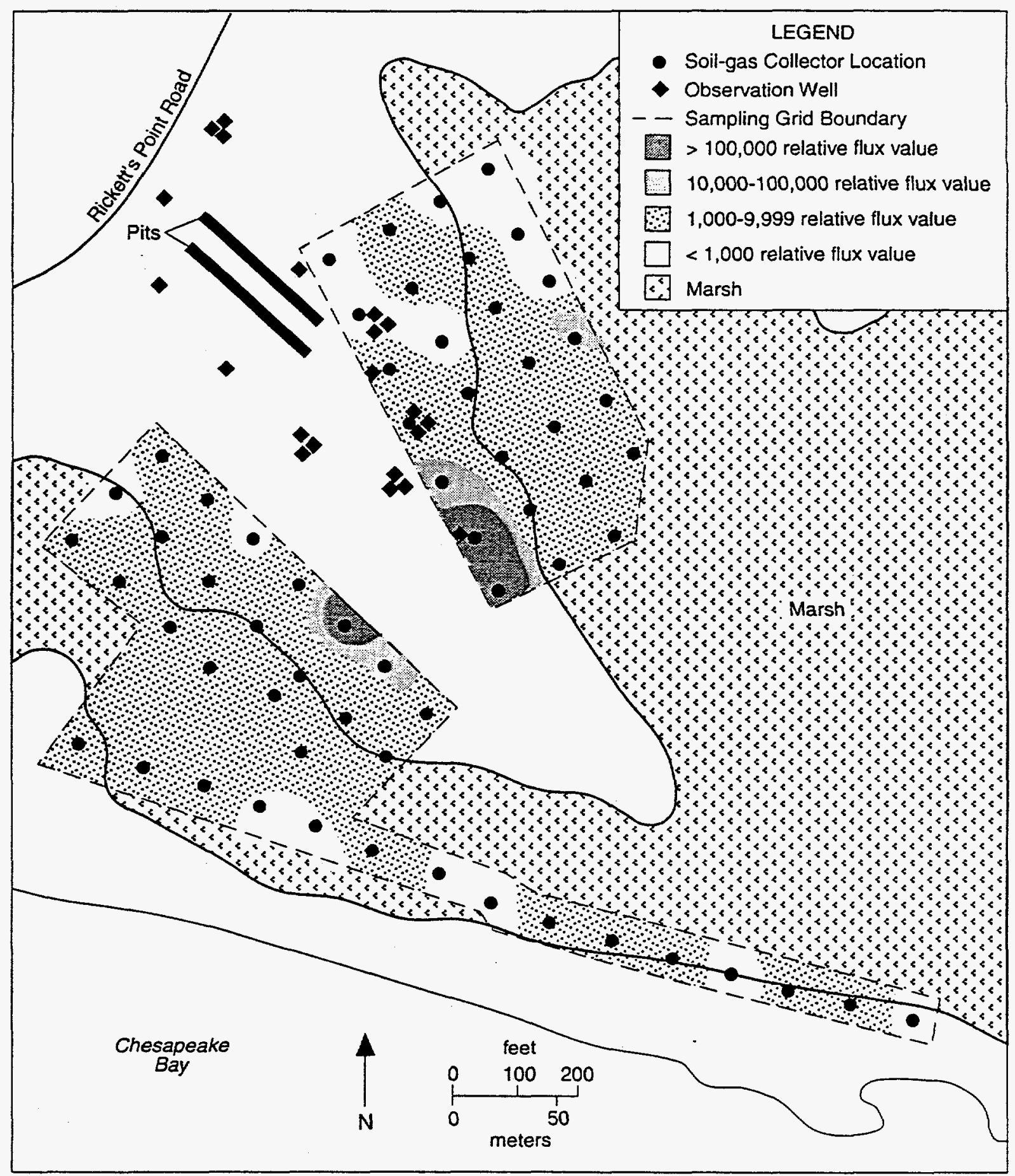

FIGURE 2.7 Relative Contours for Heavy Aromatics in Soil Gas from the Toxic Burning Pits Area (Source: Adapted from Hughes 1993) 
TABLE 2.2 Analytical Results for Analysis of Soil Samples from the Toxic Burning Pits AOC Main Burning Pits, January 1983

\begin{tabular}{|c|c|c|c|}
\hline \multirow[b]{2}{*}{ Parameter $^{\mathrm{a}}$} & \multicolumn{3}{|c|}{$\begin{array}{l}\text { Parameter Concentrations } \\
\text { (mg/kg except as noted) }\end{array}$} \\
\hline & $\begin{array}{l}\text { Back- } \\
\text { ground }^{b}\end{array}$ & Pit $1^{\mathrm{c}}$ & Pit $2^{\mathrm{c}}$ \\
\hline Arsenic & $<0.481$ & 3.56 & $<0.53$ \\
\hline Barium & 110 & 247 & 257 \\
\hline Cadmium & 0.84 & 4.46 & 2.19 \\
\hline Chromium & 74.70 & 413 & 192 \\
\hline Iron & 6,000 & 18,900 & 17,000 \\
\hline Lead & 76.90 & 717 & 281 \\
\hline Manganese & 153 & 169 & 206 \\
\hline Mercury & 0.034 & 0.080 & 0.008 \\
\hline Potassium & 857 & 1,450 & 1,650 \\
\hline Zinc & 250 & 1,510 & 810 \\
\hline pH (standard units) & 6.30 & 8.50 & 8.80 \\
\hline Nitrate & 295 & 316 & 249 \\
\hline Total phosphorus & 9.00 & $<0.50$ & $<0.25$ \\
\hline Cyanide & $<0.50$ & $<0.50$ & $<0.50$ \\
\hline $\begin{array}{l}\text { Petroleum } \\
\text { hydrocarbons }\end{array}$ & 113 & 800 & 850 \\
\hline Phenols & 0.37 & $<0.13$ & 0.31 \\
\hline Toluene ( $\mu \mathrm{g} / \mathrm{kg})$ & $<20.00$ & 32.00 & 28.00 \\
\hline Ethylbenzene $(\mu \mathrm{g} / \mathrm{kg})$ & 20.00 & $<20.00$ & $<20.00$ \\
\hline
\end{tabular}

a Table lists all parameters detected at least once.

b Locations of background samples not given.

c Based on available information, it is inferred that Pit 1 is the northern main burning pit and Pit 2 is the southern main burning pit.

Source: Adapted from Princeton Aqua Science (1984). 


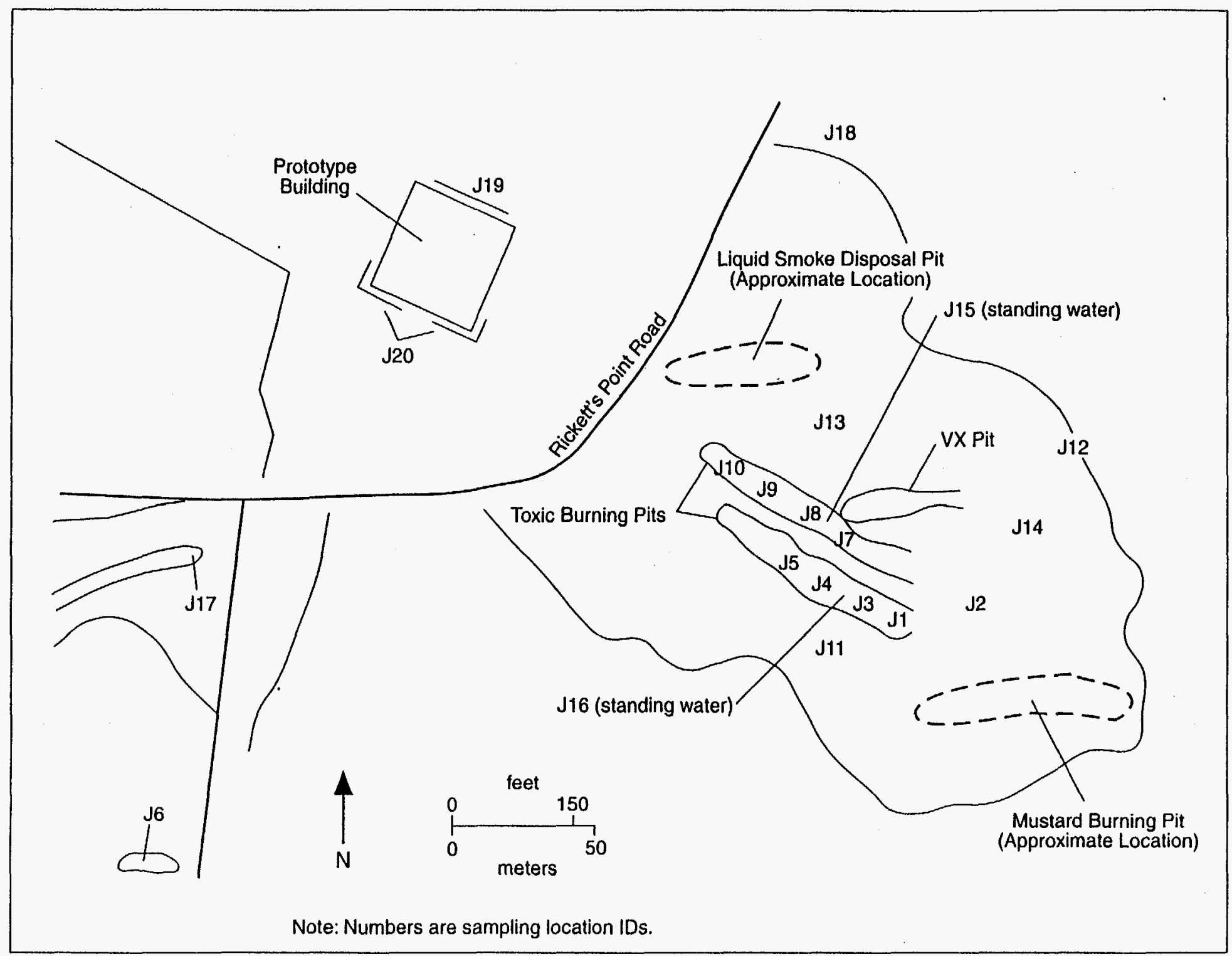

FIGURE 2.8 Locations in the Toxic Burning Pits Area where Surface Soil and Surface Water Samples Were Collected during the 1986 RCRA Facility Assessment (Source: Adapted from Nemeth 1989) 
TABLE 2.3 Analytical Results for Analysis of Soil Samples J1-J20 from the Toxic Burning Pits, 1986

\begin{tabular}{|c|c|c|c|c|c|c|c|c|c|}
\hline Parameter $^{\mathbf{a}}$ & J1 & $\mathrm{J} 2^{\mathrm{b}}$ & J3 & $\mathrm{J} 4$ & J5 & J6 & J7 & J8 & J9 \\
\hline \multicolumn{10}{|c|}{ Total Metals (mg/kg) } \\
\hline Arsenic & 54.8 & 25.2 & 21.5 & 40.5 & 18.5 & 9.7 & 47.3 & 25.7 & 43.9 \\
\hline Barium & 592 & 277 & 313 & 90.5 & 134 & $<60$ & 488 & 172 & 296 \\
\hline Cadmium & 8.13 & 4.57 & 2.52 & 4.88 & 1.58 & 2.20 & 17.3 & 8.64 & 6.10 \\
\hline Chromium & 75.5 & 54.4 & 45.9 & 95.9 & 70.8 & 10.7 & 73.3 & 76.0 & 53.3 \\
\hline Lead & 472 & 548 & 378 & 85.3 & 60.3 & 38.5 & 2,998 & 720 & 1,369 \\
\hline Mercury & 0.78 & 0.87 & 0.46 & 0.15 & 0.22 & 0.17 & 2.16 & 10.8 & 7.29 \\
\hline Silver & 14.0 & $<5.0$ & $<5.0$ & 12.1 & $<5.0$ & $<5.00$ & 15.2 & 7.01 & $<5.0$ \\
\hline \multicolumn{10}{|c|}{ Extractable Metals (mg/L) } \\
\hline Cadmium & $<0.10$ & $<0.10$ & $<0.10$ & $<0.10$ & $<0.10$ & $<0.10$ & 0.228 & $<0.10$ & $<0.10$ \\
\hline Lead & $<0.50$ & $<0.50$ & $<0.50$ & $<0.50$ & $<0.50$ & $<0.50$ & 5.23 & $<0.50$ & $<0.50$ \\
\hline \multirow[t]{2}{*}{ Silver } & $<0.50$ & $<0.50$ & $<0.50$ & $<0.50$ & $<0.50$ & $<0.50$ & $<0.50$ & $<0.50$ & $<0.50$ \\
\hline & J10 & J11 & $\mathrm{J} 12$ & J13 & J14 & J17 & J18 & J19 & $\mathrm{J} 20$ \\
\hline \multicolumn{10}{|c|}{ Total Metals (mg/kg) } \\
\hline Arsenic & 32.2 & 12.6 & 24.1 & 8.26 & 28.7 & 15.9 & 6.5 & 9.74 & 12.3 \\
\hline Barium & 208 & 101 & 855 & 107 & 256 & $<60$ & 81.4 & $<60$ & $<60$ \\
\hline Cadmium & 4.75 & 0.27 & 3.57 & 1.01 & 1.47 & 5.02 & $<0.20$ & 5.38 & 16.6 \\
\hline Chromium & 58.0 & 12.1 & 80.1 & 19.2 & 30.4 & 63.9 & 6.65 & 15.4 & 13.5 \\
\hline Lead & 4,101 & 15.8 & 26,040 & 41.8 & 1,522 & 203 & 12.1 & 140 & 1,622 \\
\hline Mercury & 6.10 & 0.11 & 0.77 & 0.11 & 0.59 & 0.20 & $<0.10$ & 0.28 & 3.40 \\
\hline Silver & $<5.0$ & $<5.0$ & $<5.0$ & $<5.0$ & $<5.0$ & 8.64 & $<5.0$ & $<5.0$ & $<5.0$ \\
\hline \multicolumn{10}{|c|}{ Extractable Metals (mg/L) } \\
\hline Cadmium & $<0.10$ & $<0.10$ & $<0.10$ & $<0.10$ & $<0.10$ & $<0.10$ & $<0.10$ & $<0.10$ & 0.112 \\
\hline Lead & $<0.50$ & $<0.50$ & 31.2 & $<0.50$ & $<0.50$ & $<0.50$ & $<0.50$ & $<0.50$ & $<0.50$ \\
\hline Silver & $<0.50$ & $<0.50$ & $<0.50$ & $<0.50$ & 0.154 & $<0.50$ & $<0.50$ & $<0.50$ & $<0.50$ \\
\hline
\end{tabular}

a Includes parameters that were detected in at least one soil sample.

b VOCs were measured in sample $\mathrm{J} 2$ only; $1,000 \mu \mathrm{g} / \mathrm{kg}$ TRCLE and traces of other VOCs were found.

Source: Nemeth (1989). 
Composite samples from locations 1 and 2 contained 13,000 $\mu \mathrm{g} / \mathrm{kg}$ heptachlor epoxide and lower concentrations of other pesticides. Aroclor 1248 (a PCB) was detected at a concentration of $230,000 \mu \mathrm{g} / \mathrm{kg}$. Composites from locations 3 through 5,7 through 10,19 , and 20 (near the PB) also contained pesticides - 1,000 $\mu \mathrm{g} / \mathrm{kg}$ each dichlorodiphenyldichloroethane (DDD), dichlorodiphenyldichloroethylene (DDE), and dichlorodiphenyltrichloroethane (DDT) (in locations 19 and 20 only); and $3,700 \mu g / k g$ PCBs (locations 3 through 5 only). Hughes (1993) states that detection of pesticides in samples containing PCBs may represent false positives. PCBs reportedly were used as heat-transfer fluids at the Edgewood Area and disposed of at J-Field (Nemeth 1989). Trace concentrations of organic compounds were also detected in samples: TRCLE (at 1,000 $\mu \mathrm{g} / \mathrm{kg}$ ) and traces of other VOCs in the sample from location 2 , the only sample analyzed for VOCs.

Soil samples were collected by the USGS from depths of approximately $1 \mathrm{ft}$ below land surface at 36 sites in J-Field, including the TBP area (Figure 2.9). The samples were analyzed for indicator parameters, metals, VOCs, semivolatile compounds, and explosives (Hughes 1992). The results of these analyses, except for explosives, are presented in Table 2.4. Soil samples showed some metals contamination, especially at locations 39 and 30 , north of the Mustard Pit. Traces of organic compounds were also detected in some samples.

Soil samples were also collected in the TBP area by Weston in October 1992 (Figure 2.10). The samples were collected at depths of 2, 4, and $6 \mathrm{ft}$ in the pits; and at depths of $3 \mathrm{in}$. and $1 \mathrm{ft}$ in the marshes and pushout areas. Tables 2.5 and 2.6 summarize the analytic results for parameters detected in some of these samples.

The highest concentrations of organic compounds were found in the area of the Mustard Pit: TCLEA, up to $3,270,000 \mu \mathrm{g} / \mathrm{kg}$ at $6 \mathrm{ft} ; 1,1,2$-trichloroethane (112TCE), up to $8,500 \mu \mathrm{g} / \mathrm{kg}$ at $6 \mathrm{ft}$; TCLEE, up to $25,700 \mu \mathrm{g} / \mathrm{kg}$ at $6 \mathrm{ft}$; and TRCLE, up to $263,000 \mu \mathrm{g} / \mathrm{kg}$ at $6 \mathrm{ft}$. Organic compounds, including TCLEA, 112TCE, acetone, methylene chloride, and TRCLE, were detected in the main burning pits (see Table 2.6). High levels of PCBs were detected in the southern main pit (up to $143,000 \mu \mathrm{g} / \mathrm{kg}$ at $2 \mathrm{ft}$ ), the mustard pit (up to $178 \mu \mathrm{g} / \mathrm{kg}$ at $6 \mathrm{ft}$ ), the southern marsh (up to $3,200 \mu \mathrm{g} / \mathrm{kg}$ at $1 \mathrm{ft}$ ), and the pushout area northwest of the main pits (up to $3,800 \mu \mathrm{g} / \mathrm{kg}$ at $1 \mathrm{ft}$ ). The highest concentrations of lead were found in the southern main pit $(340 \mathrm{mg} / \mathrm{kg}$ at $2 \mathrm{ft}$ ), the mustard pit (121 $\mathrm{mg} / \mathrm{kg}$ at $6 \mathrm{ft}$ ), the southern marsh - $(542 \mathrm{mg} / \mathrm{kg}$ at $1 \mathrm{ft})$, the marsh east of the main pits $(79,800 \mathrm{mg} / \mathrm{kg}$ at $3 \mathrm{in.})$, and the pushout area northwest of the main pits $(1,180 \mathrm{mg} / \mathrm{kg}$ at $3 \mathrm{in}$.$) .$

\section{Surface Water}

Surface water samples (J15 and J16) were collected from the TBP area as part of the 1986 RFA (Nemeth 1989). Sampling locations are shown in Figure 2.8. Samples were analyzed for metals, explosives-related compounds, inorganic compounds, gross alpha, gross beta, radium-226, radium-228, VOCs, semivolatile compounds, and PCBs. The results are summarized in Table 2.7 for locations $\mathrm{J} 15$ and $\mathrm{J} 16$. 


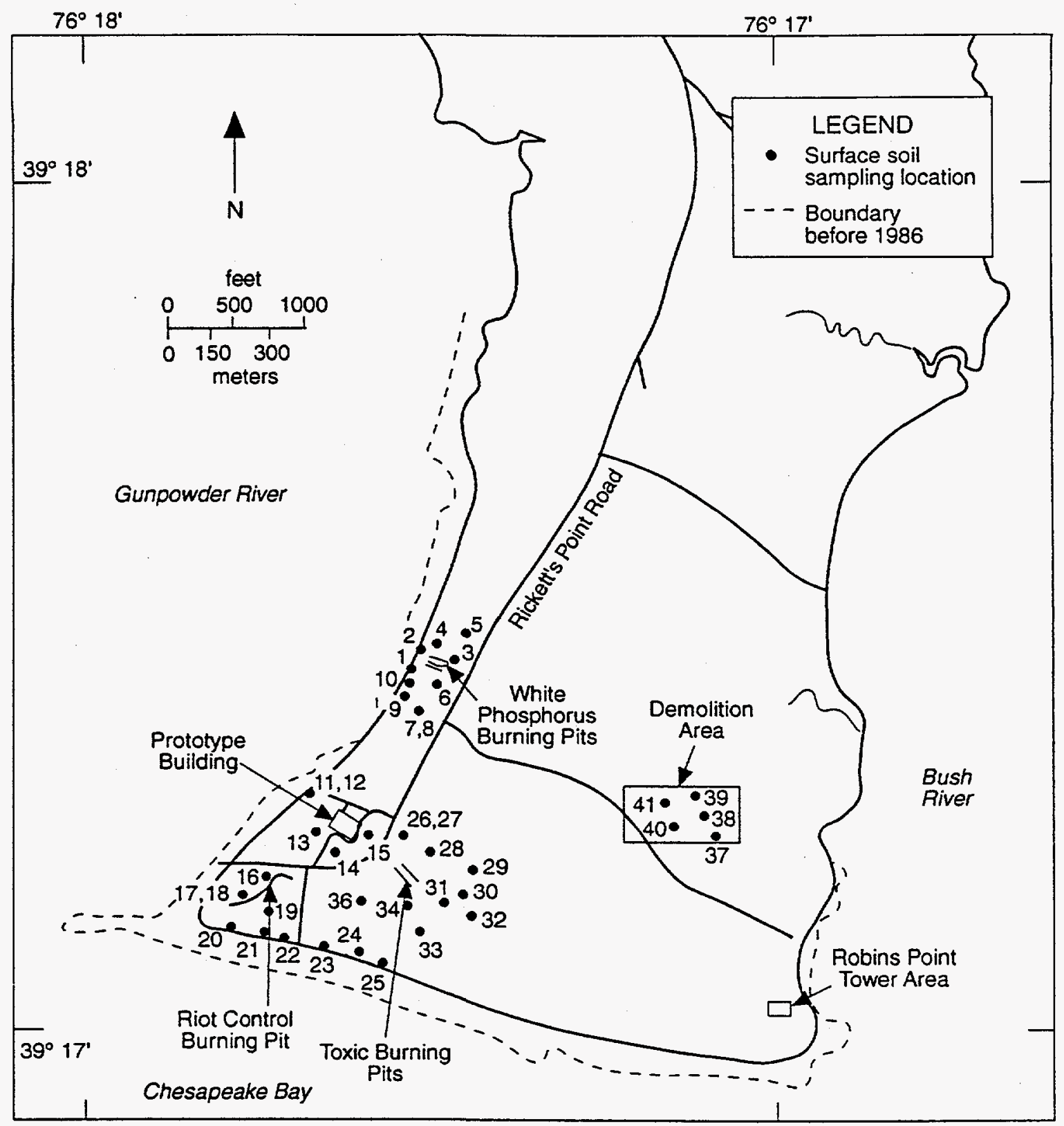

FIGURE 2.9 Locations where Soil Samples Were Collected by the USGS in 1991 (Source: Adapted from Hughes 1992) 
TABLE 2.4 Analytical Results for Analysis of Soil Samples from the Toxic Burning Pits Area, April 1991

\begin{tabular}{|c|c|c|c|c|c|c|c|c|c|c|c|c|c|}
\hline \multirow[b]{2}{*}{ Parameter } & \multicolumn{13}{|c|}{ Concentration by Soil Sample Location ${ }^{\mathbf{b}}$} \\
\hline & 23 & 24 & 25 & 26 & 27 & 28 & 29 & 30 & 31 & 32 & 33 & 34 & 36 \\
\hline \multicolumn{14}{|l|}{ Metals (mg/kg) } \\
\hline Arsenic & 3.7 & 3.2 & ND & 4.5 & 4.2 & 7.8 & 49 & 21 & 2.6 & 3.3 & 3.5 & 6.6 & 3.2 \\
\hline Cadmium & ND & ND & ND & ND & ND & 2.4 & 16 & ND & ND & ND & ND & ND & ND \\
\hline Chromium & 14 & 11 & 6.6 & 16 & 15 & 37 & 121 & 46 & 12 & 13 & 13 & 17 & 17 \\
\hline Copper & 21 & 50 & 10 & 22 & 19 & 233 & 786 & 48 & 4.2 & 11 & 15 & 40 & 17 \\
\hline Lead & 17 & 40 & 14 & 41 & 38 & 662 & 87,100 & 952 & 15 & 17 & 29 & 42 & 19 \\
\hline Antimony & ND & ND & ND & ND & ND & ND & 1,120 & ND & $\mathrm{ND}$ & ND & ND & ND & ND \\
\hline Zinc & ND & ND & 20 & 96 & 157 & ND & 7,960 & ND & 25 & ND & ND & ND & ND \\
\hline \multicolumn{14}{|c|}{ Volatile Organic Compounds ( $\mu \mathrm{g} / \mathrm{kg}$ ) } \\
\hline Acetone & 5.89 & 13.9 & 6.73 & 15.8 & 6.75 & 9.80 & 15.7 & 4.88 & 2.24 & ND & 21.0 & ND & ND \\
\hline cis-1,2-Dichloroethylene & NA & NA & NA & NA & NA & 2.4 & NA & 2.40 & NA & NA & NA & NA & NA \\
\hline Trichloroethylene & ND & ND & ND & ND & ND & 1.12 & ND & ND & ND & ND & ND & ND & ND \\
\hline \multirow{2}{*}{\multicolumn{14}{|c|}{ Semivolatile Organic Compounds ( $\mu \mathrm{g} / \mathrm{kg})$}} \\
\hline Butylbenzl phthalate & ND & 598 & & & 720 & & 580 & & & & & & \\
\hline Benzoic acid & 353 & 7,000 & 1,500 & ND & ND & ND & 420 & 420 & ND & ND & 2,100 & ND & ND \\
\hline \multicolumn{14}{|l|}{ Other $(\mathrm{mg} / \mathrm{kg})$} \\
\hline Total Kjeldahl nitrogen & 1,040 & 2,340 & 695 & 249 & 247 & 637 & 605 & 488 & 627 & 1,030 & 1,730 & 639 & 552 \\
\hline Total organic carbon & 958 & 2,590 & 1,630 & 1,190 & 1,720 & 1,590 & 1,630 & 1,190 & 1,390 & 871 & 1,810 & 752 & 1,010 \\
\hline Total organic halogen & ND & ND & 157 & 20 & 48 & 37 & 34 & ND & ND & ND & $\mathrm{ND}$ & ND & ND \\
\hline
\end{tabular}




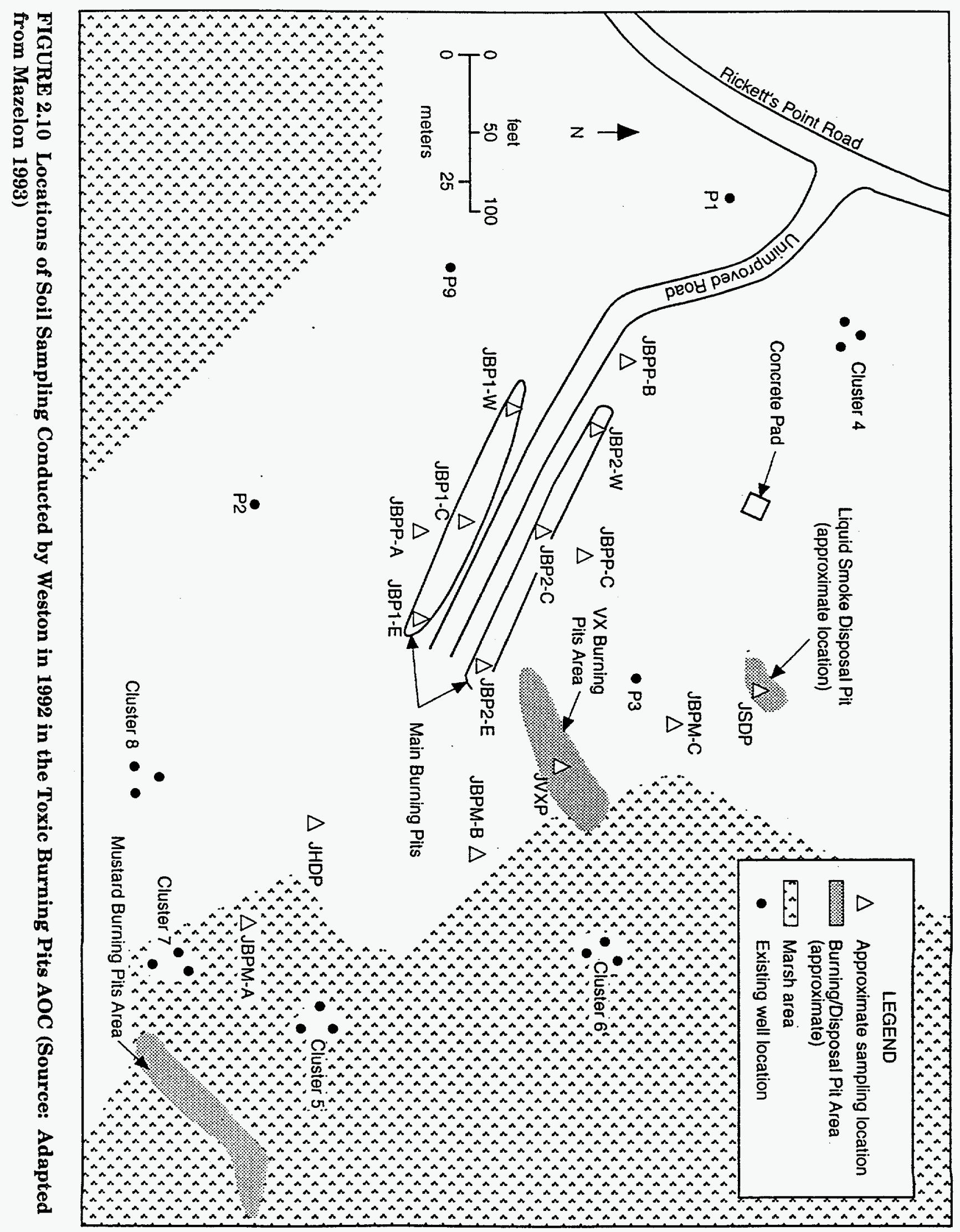


TABLE 2.5 Analytical Results for Target Compound List Analytes in Selected Soil Samples from the Toxic Burning Pits, $1992^{\mathrm{a}}$

\begin{tabular}{|c|c|c|c|c|c|c|c|c|}
\hline \multirow[b]{2}{*}{$\mathrm{TCL}^{\mathrm{b}}$ Analyte } & \multicolumn{8}{|c|}{ Concentrations $(\mu \mathrm{g} / \mathrm{kg})$ by Soil Sample Location } \\
\hline & $\mathrm{JBP} 1-\mathrm{E}(2)^{\mathrm{c}}$ & JBP1-E(4*) & JBP2-E(2) & JBP2-E(4') & $\operatorname{JVXP}\left(4^{\prime}\right)$ & $\operatorname{JVXP}\left(6^{\prime}\right)$ & $\operatorname{JSDP}\left(4^{\prime}\right)$ & $\mathrm{JSDP}\left(6^{\prime}\right)$ \\
\hline \multicolumn{9}{|l|}{ Volatile Organic Compounds } \\
\hline 1,1,2,2-Tetrachloroethane & 6.74 & $N^{d}$ & ND & ND & 167 & 39 & 15,200 & 25.6 \\
\hline 1,1,2-Trichloroethane & ND & ND & ND & ND & ND & ND & 80.5 & ND \\
\hline 1,1-Dichloroethane & ND & ND & ND & ND & ND & ND & ND & ND \\
\hline 1,1-Dichloroethylene & ND & ND & ND & ND & ND & ND & ND & ND \\
\hline 1,2-Dichloroethane & $\mathrm{ND}$ & ND & ND & ND & ND & ND & ND & ND \\
\hline Acetone & 16.4 & 33 & 44.7 & 116 & ND & ND & 344 & ND \\
\hline Benzene & ND & ND & ND & ND & ND & ND & ND & ND \\
\hline Carbon tetrachloride & ND & ND & ND & ND & ND & ND & ND & ND \\
\hline Chloroform & ND & $\mathrm{ND}$ & ND & ND & ND & ND & ND & ND \\
\hline Methylene chloride & ND & 6.23 & ND & 6.30 & 7.03 & 8.25 & 44.0 & 12.4 \\
\hline Tetrachloroethylene & ND & ND & ND & ND & ND & ND & ND & ND \\
\hline Toluene & ND & ND & ND & ND & ND & ND & ND & ND \\
\hline trans-1,2-Dichloroethylene & ND & ND & ND & ND & ND & ND & 78.0 & ND \\
\hline Trichloroethylene & 28.1 & ND & ND & ND & ND & 15.8 & 345 & ND \\
\hline Vinyl chloride & ND & ND & ND & ND & ND & ND & ND & ND \\
\hline Xylenes & 12.4 & ND & ND & ND & ND & ND & ND & ND \\
\hline \multicolumn{9}{|c|}{ Semivolatile Organic Compounds } \\
\hline 2-Methylnaphthalene & 471 & ND & ND & ND & ND & ND & ND & ND \\
\hline Hexachloroethane & ND & ND & ND & ND & ND & ND & ND & ND \\
\hline Pyrene & 580 & ND & ND & ND & ND & ND & ND & ND \\
\hline \multicolumn{9}{|l|}{ PCBs } \\
\hline Aroclor 1248 & 143,000 & 1,180 & ND & ND & ND & ND & ND & ND \\
\hline Aroclor 1254 & ND & ND & 224 & ND & ND & ND & ND & ND \\
\hline
\end{tabular}


TABLE 2.5 (Cont.)

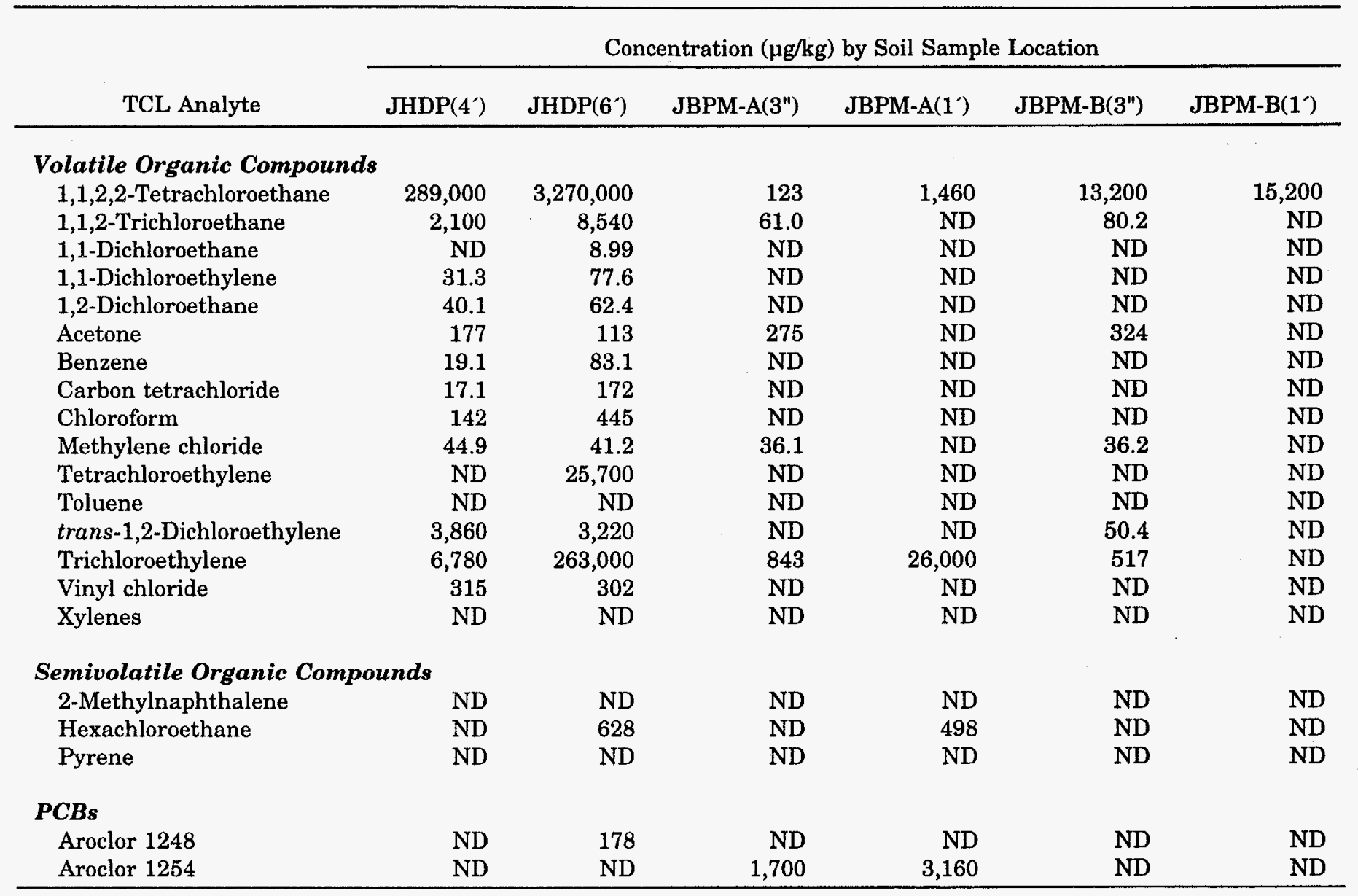

a Only detected analytes are reported; for samples with duplicate analyses, the higher value is reported.

b TCL $=$ Target Compound List.

c Sample depth shown in parentheses.

d $N D=$ not detected. 
TABLE 2.6 Analytical Results for Target Analyte List Analytes in Selected Soil Samples from the Toxic Burning Pits, 1992 $^{\mathrm{a}}$

\begin{tabular}{|c|c|c|c|c|c|c|c|c|c|c|c|}
\hline \multirow[b]{2}{*}{$\mathrm{TAL}^{\mathrm{b}}$ Analyte } & \multicolumn{11}{|c|}{ Concentration (mg/kg) by Soil Sample Location } \\
\hline & \multicolumn{2}{|c|}{ JBP1-E $\left(2^{\prime}\right)^{\mathrm{c}}$} & \multicolumn{2}{|c|}{ JBP1-E(4) } & \multicolumn{2}{|c|}{ JBP2-E(2') } & \multicolumn{2}{|c|}{ JBP2-E(4') } & $\operatorname{JVXP}\left(4^{\prime}\right)$ & \multirow{2}{*}{$\frac{\operatorname{JVXP}\left(6^{\prime}\right)}{N D}$} & \multirow{2}{*}{$\frac{\operatorname{JSDP}\left(4^{\prime}\right)}{\mathrm{ND}}$} \\
\hline Antimony & \multicolumn{3}{|c|}{5.08} & \multicolumn{2}{|l|}{$\mathrm{ND}^{\mathrm{d}}$} & \multicolumn{2}{|l|}{ ND } & ND & ND & & \\
\hline Arsenic & \multirow{2}{*}{\multicolumn{2}{|c|}{5.02}} & \multicolumn{2}{|r|}{4.18} & \multicolumn{2}{|r|}{3.50} & & 2.33 & 1.19 & ND & 1.38 \\
\hline Beryllium & & & \multicolumn{2}{|r|}{0.453} & \multicolumn{2}{|r|}{0.228} & & 0.380 & ND & ND & $\mathrm{ND}$ \\
\hline Cadmium & \multicolumn{2}{|r|}{3.21} & \multicolumn{2}{|r|}{ ND } & \multicolumn{2}{|r|}{ ND } & & ND & ND & ND & ND \\
\hline Chromium & \multicolumn{2}{|r|}{36.6} & \multicolumn{2}{|r|}{18.2} & \multicolumn{2}{|r|}{14.2} & & 12.7 & 5.33 & 3.15 & 4.09 \\
\hline Cobalt & \multicolumn{2}{|r|}{5.64} & \multicolumn{2}{|r|}{$\mathrm{ND}$} & \multicolumn{2}{|r|}{ ND } & & ND & ND & ND & ND \\
\hline Copper & & 248 & & 10.1 & & 6.85 & & 10.1 & ND & ND & ND \\
\hline Lead & & 340 & & 10.5 & & 15.9 & & 96.3 & 10.5 & 2.6 & 3.37 \\
\hline Zinc & & 1,220 & & 123 & & 94.4 & & 76.5 & 33.8 & 13.1 & 13.5 \\
\hline & & & & Concer & ntrati & $\mathrm{n}(\mathrm{mg} / \mathrm{k}$ & g) by $S$ & oil Sam & ole Location & & \\
\hline TAL Analyte & $\operatorname{JSDP}\left(6^{\prime}\right)$ & JHI & $P\left(4^{\prime}\right)$ & JHDP & $P\left(6^{\prime}\right)$ & JBPM & $A\left(3^{\prime \prime}\right)$ & JBPl & A-A $\left(1^{\prime}\right)$ & JBPM-B(3") & JBPM-B(1) \\
\hline Antimony & ND & & ND & & ND & & ND & & ND & 13.7 & ND \\
\hline Arsenic & ND & & 3.94 & & 6.29 & & 4.80 & & 22.5 & 7.49 & 3.58 \\
\hline Beryllium & ND & & 0.457 & & 0.408 & & 0.434 & & 0.263 & 0.339 & 0.398 \\
\hline Cadmium & ND & & ND & & 7.23 & & 2.95 & & 6.05 & 5.94 & ND \\
\hline Chromium & 5.54 & & 11.9 & & 44.1 & & 37.8 & & 67.9 & 53.4 & 15.6 \\
\hline Cobalt & ND & & ND & & ND & & ND & & ND & 6.41 & ND \\
\hline Copper & ND & & ND & & 123 & & 305 & & 392 & 521 & 4.77 \\
\hline Lead & 8.22 & & 10.5 & & 121 & & 145 & & 542 & 79,800 & 11.2 \\
\hline Zinc & 12.8 & & 25.1 & & 296 & & 690 & & 678 & 1,000 & 46.9 \\
\hline
\end{tabular}

a Only detected analytes are reported; for samples with duplicate analyses, the higher value is reported.

b $\mathrm{TAL}=$ Target Analyte List.

c Sample depth shown in parentheses.

d $\mathrm{ND}=$ not detected.

Source: Mazelon (1993). 
TABLE 2.7 Analytical Results for Surface

Water Samples from the Toxic Burning

Pits Area, 1986

\begin{tabular}{lrr}
\hline & \multicolumn{2}{c}{ Location } \\
\cline { 2 - 3 } \multicolumn{1}{c}{ Parameter $^{\mathrm{a}}$} & $\mathrm{J} 15$ & $\mathrm{~J} 16$ \\
\hline & & \\
Dissolved Metals $(\boldsymbol{\mu g} / \mathrm{L})$ & $<1.0$ & 2.0 \\
Cadmium & 40 & 104 \\
Lead & 0.60 & $<0.20$ \\
Mercury & & \\
& & \\
Inorganic Compounds $(\boldsymbol{\mu g} / \mathrm{L})$ & \\
Nitrate and nitrite as N & $<30$ & 60 \\
Sulfate & 12,000 & 16,000 \\
Chloride & 3,000 & 4,000 \\
Total dissolved solids & $\mathrm{NA}$ & 34,000 \\
& & \\
Radioactivity (pCi/L) & & \\
Gross alpha & $<0.8$ & 7.0 \\
Gross beta & 5.7 & 15 \\
Radium-226 & $\mathrm{NA}$ & 0.50 \\
Radium-228 & $\mathrm{NA}$ & 1.4 \\
\hline
\end{tabular}

a Includes parameters that were detected in one or more samples. No detection limits given for VOCs, semivolatile compounds, and PCBs.

b $\mathrm{NA}=$ Not analyzed.

Source: Nemeth (1989).

The surface water contained some lead contamination. The lead concentration at location 16 was above the primary drinking water standard $(50 \mu \mathrm{g} / \mathrm{L})$. The gross alpha radionuclide was also slightly elevated at location 16 . The radioactivity measurements were consistent with results from a field radiation survey of the TBP for materials emitting beta and gamma radioactivity. No radiation above background levels was detected (Nemeth 1989).

The USGS collected nearshore surface water samples from the Gunpowder River (9 locations) and the Chesapeake Bay (11 locations) at low tide. One sample was collected onshore in a drainage ditch. Sampling locations are shown in Figure 2.11. Filtered and unfiltered samples were analyzed for water quality parameters, metals, and a few organic compounds. Nitrate concentrations in samples from locations 3, 7, and 13 ranged from 280 to $400 \mu \mathrm{g} / \mathrm{L}$. The metals data showed the presence of lead (from not detected $[\mathrm{ND}]^{1}$ to

1 The detection limits for analyses were not reported. 


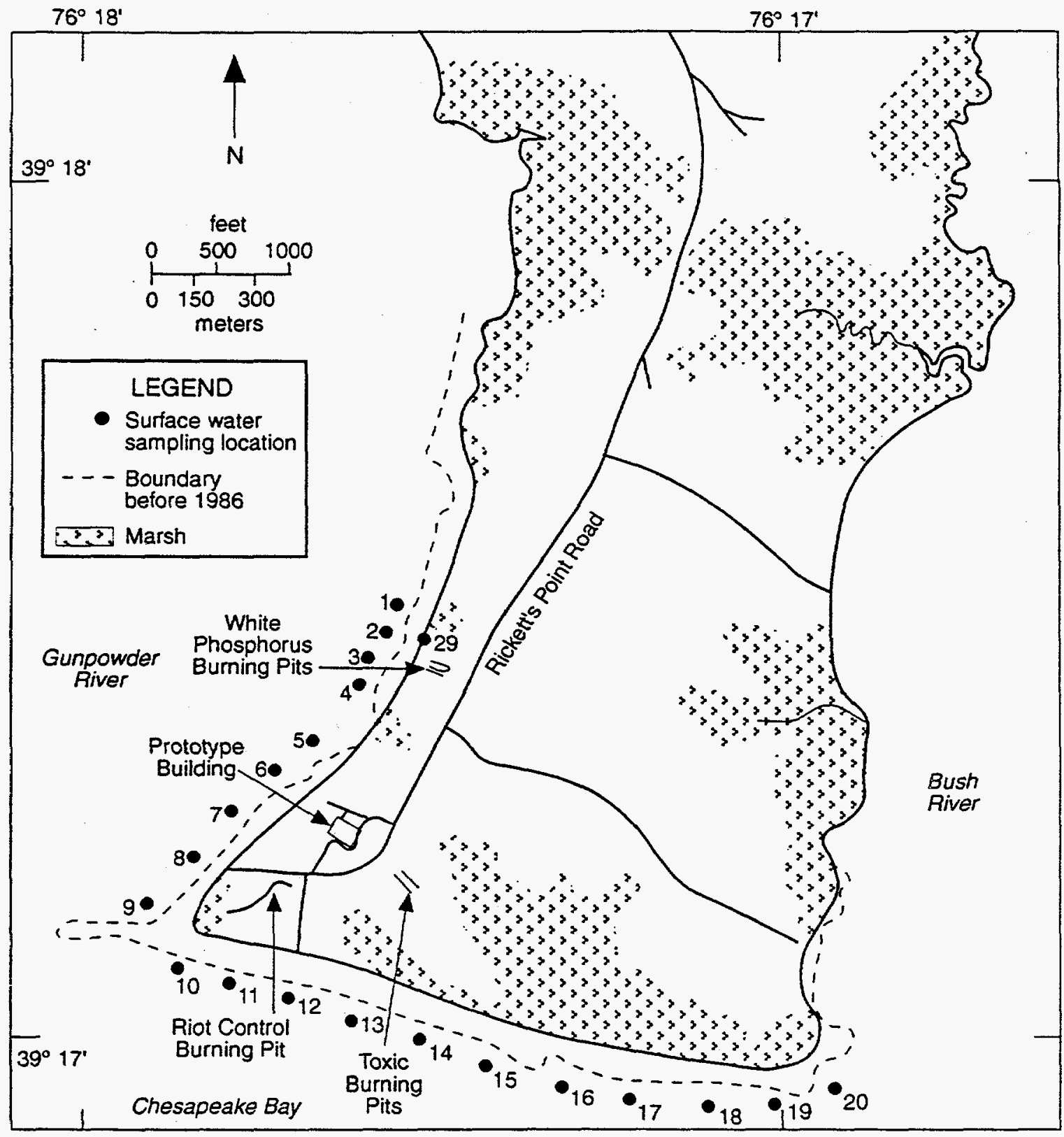

FIGURE 2.11 Locations of Surface Water Samples Collected at J-Field in 1988 (Source: Adapted from USGS 1991) 
$28 \mu \mathrm{g} / \mathrm{L})$ and zinc $(50-133 \mu \mathrm{g} / \mathrm{L})$ at locations 1 through 4 . Lead and zinc concentrations at the other locations ranged from ND to 2.68 and $48 \mu \mathrm{g} / \mathrm{L}$, respectively. Mercury and nickel concentrations were slightly elevated at location 1 ( 0.54 and $33.7 \mu \mathrm{g} / \mathrm{L}$, respectively). No evidence was found of elevated concentrations of arsenic, barium, or chromium. Comparison of results from filtered and unfiltered samples showed that the elevated metals concentrations may be associated with the suspended solids in the samples (Hughes 1993).

Acetone, toluene, phenol, total organic carbon (TOC), and total organic halogen (TOX) were analyzed in the filtered and unfiltered samples from nine locations. Phenol (ND to $51.9 \mu \mathrm{g} / \mathrm{L})$, TOC $(4,000-7,000 \mu \mathrm{g} / \mathrm{L})$, and TOX $(21.6-30.4 \mu \mathrm{g} / \mathrm{L})$ were detected in the unfiltered samples only. The presence of acetone in some of the samples may represent laboratory contamination. Toluene $(3.05 \mu \mathrm{g} / \mathrm{L})$ was found at location 1 (Hughes 1993).

The data for the nearshore surface water have shown essentially no contamination. Contaminants appear to be associated with the suspended solids, suggesting that the nearshore sediments may be contaminated.

In August 1992, the EPA emergency response team (ERT) collected nearshore surface water and sediment samples at 17 locations around the peninsula - in the Gunpowder and Bush rivers and in Chesapeake Bay (Figure 2.12). Filtered surface water samples were analyzed for VOCs, base neutral and acid extractable organic compounds (BNA), Target Analyte List (TAL) metals, pesticides, PCBs, and inorganic parameters (sulfate, total Kjeldahl nitrogen [TKN], total phosphorus, and cyanide). The data showed that beryllium, lead, and mercury were below their respective detection limits of $6,000,6,000$, and $200 \mu \mathrm{g} / \mathrm{L}$. Zinc concentrations ranged from $11,000 \mu \mathrm{g} / \mathrm{L}$ at locations 3,4 , and 16 to $96,000 \mu \mathrm{g} / \mathrm{L}$ at location 6 . Nickel concentrations ranged from $28,000 \mu \mathrm{g} / \mathrm{L}$ at most locations to $38,000 \mu \mathrm{g} / \mathrm{L}$ at location 9 . No cyanide, VOCs, pesticides, or PCBs were detected.

Sediment samples, collected at the same locations as the surface water, were analyzed for CWAs and CWA degradation products, explosives, VOCs, BNA, TAL metals, pesticides, PCBs, and other parameters (TOC, sulfate, total phosphorus, TKN, and percent solids). The results indicate that there is essentially no contamination in sediments at these locations, although lead was detected at concentrations ranging from $2 \mathrm{mg} / \mathrm{L}$ at location 11 to $22 \mathrm{mg} / \mathrm{L}$ at location 17 . Arsenic and cadmium were also detected: arsenic at concentrations ranging from 1 to $6 \mathrm{mg} / \mathrm{L}$ (at location 6) and cadmium at concentrations ranging from $<0.5$ to $3 \mathrm{mg} / \mathrm{L}$ (at location 8 ). The detection limit for beryllium was fairly high, ranging from 0.5 to $2.6 \mathrm{mg} / \mathrm{L}$. The only VOC detected was acetone, up to $101 \mu \mathrm{g} / \mathrm{kg}$ at location 7.

\section{Groundwater}

Eleven groundwater monitoring wells (TH series) were installed in J-Field during the 1977 environmental survey. Locations of these wells are shown in Figure 2.13. Only one well (TH4) was installed in the area of the TBP. Well depths ranged from 20 to $25 \mathrm{ft}$. The 


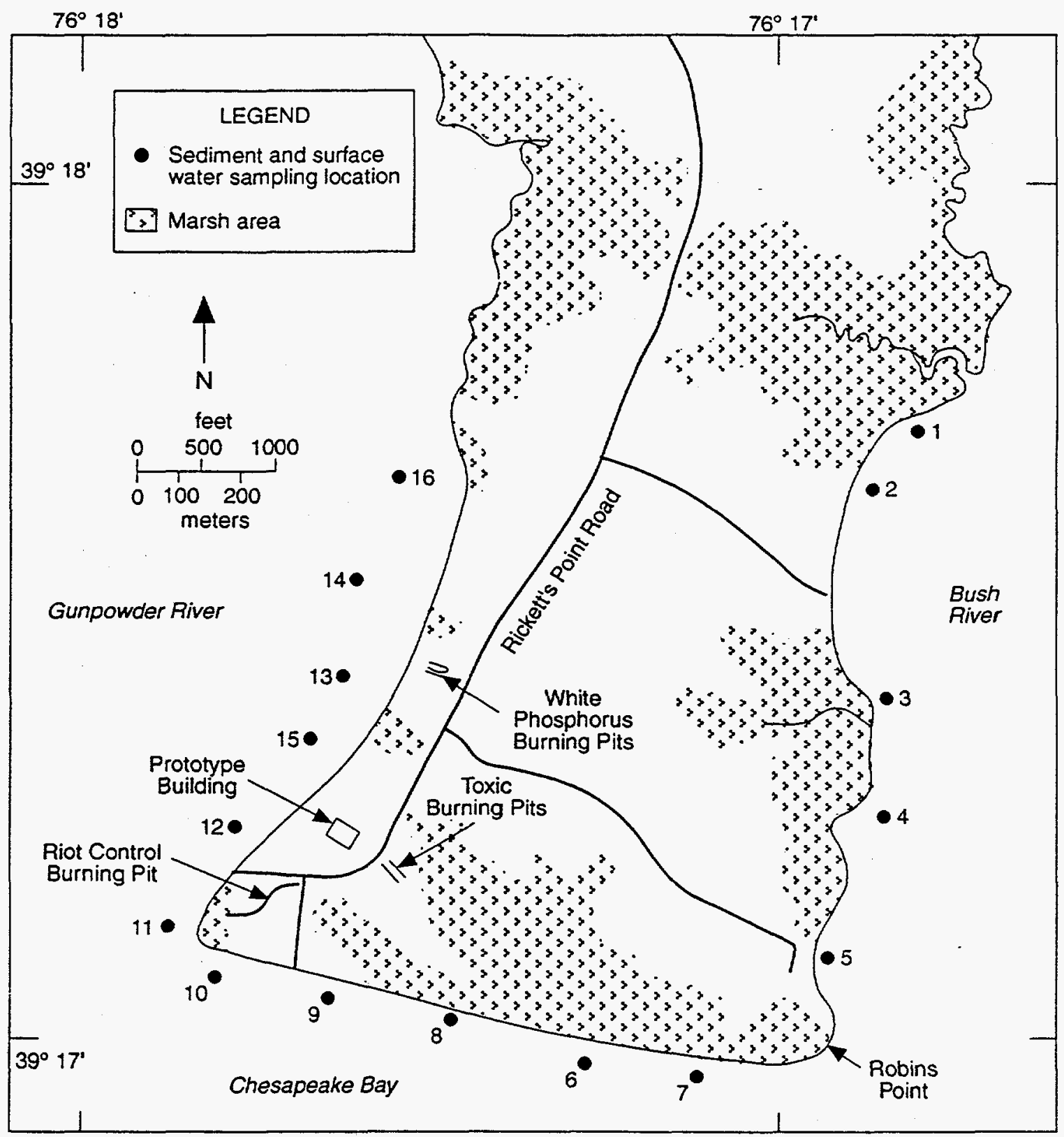

FIGURE 2.12 Locations of Surface Water and Sediment Samples Collected at J-Field in 1992 (Source: EPA 1992a) 


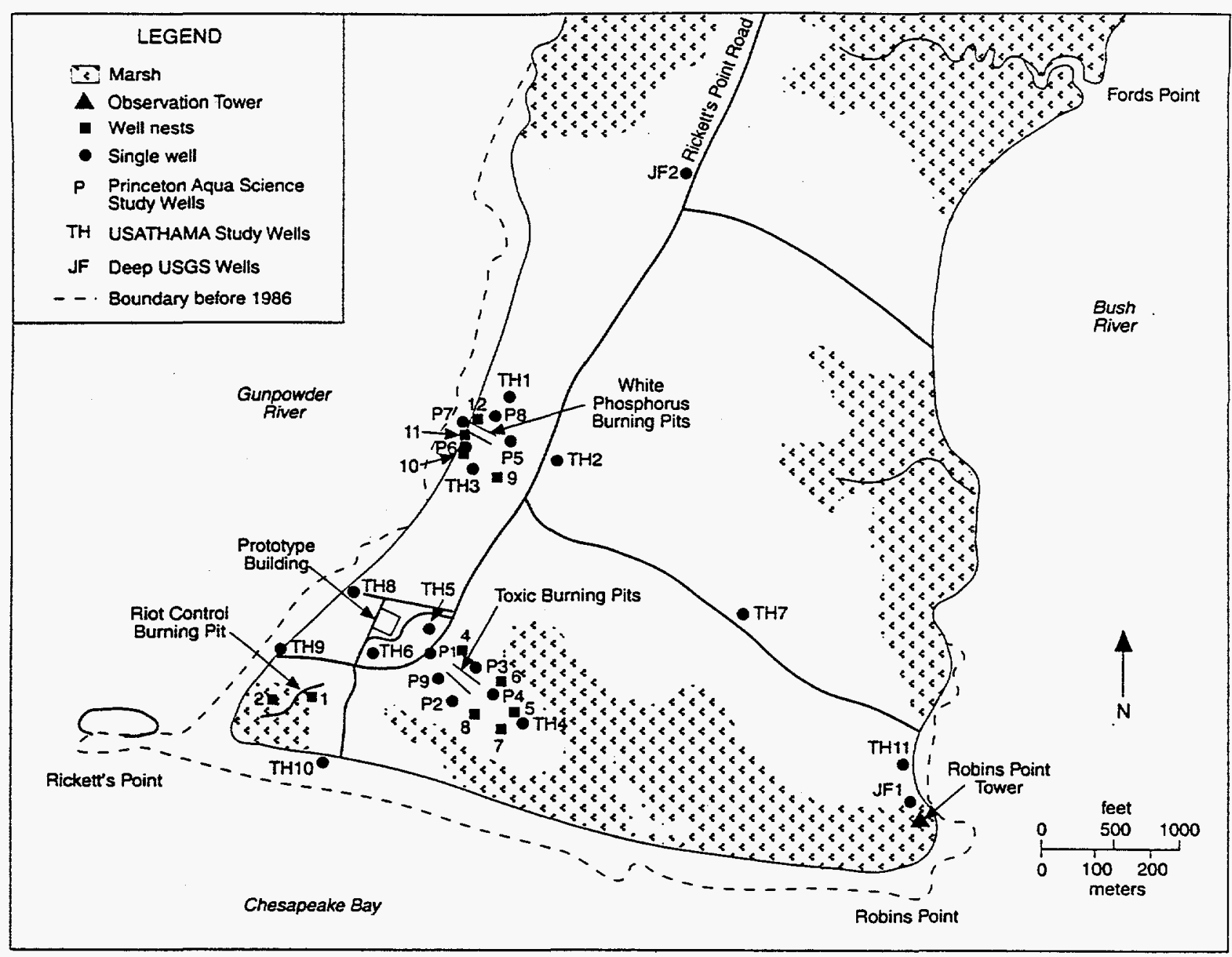

FIGURE 2.13 Locations of All Wells Installed at J-Field (Source: Adapted from Hughes 1993)

wells were screened in the surficial aquifer with 25-ft-long screens (Sonntag 1991). Samples collected from the wells in 1977 were analyzed for metals, inorganic chemicals, white phosphorus, mustard degradation products, cholinesterase inhibitors, semivolatile compounds, and VOCs. Organic contaminants (up to $200,000 \mu \mathrm{g} / \mathrm{L}$ ) were found in all of the wells (no data were given for $\mathrm{TH} 7$ ).

Five additional wells were installed around the TBP as part of a munitions disposal study (Figure 2.13, P series) (Princeton Aqua Science 1984). The wells were screened in the surficial aquifer from depths of $17-20 \mathrm{ft}$ with 15-ft-long screens (Sonntag 1991). Water samples collected from the wells in 1983 were analyzed for metals, nitrate, TOX, TOC, radioactivity, pesticides, herbicides, and secondary drinking water parameters. Two of the five wells (P4 and P5) contained elevated concentrations of the gross beta radionuclide (140 and $12 \mathrm{pCi} / \mathrm{L}$, respectively). Two wells (P3 and $\mathrm{P} 4$ ) contained TOX (6.6 and $7.1 \mathrm{mg} / \mathrm{L}$, 
respectively). Two wells (P2 and P5) contained elevated concentrations of nitrates (12 and $10 \mathrm{mg} / \mathrm{L}$, respectively).

The P-series wells were sampled again in 1986 as part of the Edgewood Area RFA (Nemeth 1989). The samples were analyzed for metals, explosives-related compounds, inorganic compounds, radioactivity, thiodiglycol, VOCs, semivolatile compounds, and PCBs. The results are summarized in Table 2.8. Elevated concentrations of VOCs were found in only two wells (P3 and P4), near the area exhibiting soil-gas contamination. The compounds found include trans-1,2-dichloroethylene (trans-12DCE), up to 8,500 $\mu / \mathrm{L}$ in well P4; TRCLE, up to $6,700 \mu \mathrm{g} / \mathrm{L}$ in well P4; vinyl chloride, up to $550 \mu \mathrm{g} / \mathrm{L}$ in well P3; and TCLEE, up to $420 \mu \mathrm{g} / \mathrm{L}$ in well P3. The data also indicate that the elevated gross beta activity detected in well P3 was due to naturally occurring potassium-40; however, it is not clear why potassium concentrations were so much higher in this well than in the others.

Thirty-eight additional monitoring wells were installed by the USGS in 1988 and 1989 (Sonntag 1991; Hughes 1993). Two of these wells, JF1 and JF2, were installed and screened in the Potomac Group. The 36 other wells were placed in nests of 3 at 12 different locations (Figure 2.13). Well nests JF3-JF8 were placed in the TBP area. The nested wells were screened in the confined aquifer, the leaky confining unit, and the surficial aquifer. The naming convention for the well nests involves a combination of letters and numbers. The letters with numbers (i.e., JF1-JF12) indicate the location. This location indicator code is then coupled with the numbers 1,2 , or 3 to indicate the strata being monitored. The confined aquifer is designated by the number 1 , the leaky confining unit by the number 2 , and the surficial aquifer by the number 3 .

During 1990 , samples from 55 of the 58 existing wells at J-Field were analyzed for metals, inorganic compounds, VOCs, and semivolatile organic compounds. Several of the wells were also analyzed for organosulfur, explosives, and radioactive contaminants. Wells were selected for specific contaminant analyses on the basis of the nature of disposal activities that had occurred nearby (USGS 1991).

Table 2.9 summarizes the analytical results indicating the presence of metals and other inorganic compounds. Concentrations of lead $(124 \mu \mathrm{g} / \mathrm{L})$ in well P9 and arsenic $(60 \mu \mathrm{g} / \mathrm{L})$ in well JF83 exceed maximum contaminant levels (MCLs). Both of these wells are downgradient from the TBP. Potassium concentrations ranged from not detected to $140 \mu \mathrm{g} / \mathrm{L}$. Except for one measurement at well P3, the elevated concentrations of potassium (above $50 \mu \mathrm{g} / \mathrm{L}$ ) occurred in the leaky confining unit or the confined aquifer. Movement of sea water into the groundwater may not be a source of potassium because wells with elevated potassium do not have elevated chloride concentrations.

The analytical results (summarized in Table 2.10) show that the TBP are contaminated with VOCs, and a contaminant plume in the groundwater extends downgradient to the southeast. This condition is reflected in the elevated concentrations of 112TCE, 1,2-dichloroethylene (12DCE), TCLEA, TCLEE, and TRCLE in well nests JF5, JF7, and JF8. The concentrations are highest in the surficial aquifer - up to $7,150 \mu \mathrm{g} / \mathrm{L} 12 \mathrm{DCE}$ in wells 
TABLE 2.8 Analytical Results for Groundwater from the P-Series Monitoring Wells, 1986

Concentration by Well

\begin{tabular}{|c|c|c|c|c|c|}
\hline Parameter $^{\mathrm{a}}$ & $\mathrm{P} 1$ & $\mathrm{P} 2$ & P3 & $\mathrm{P} 4$ & P9 \\
\hline \multicolumn{6}{|c|}{ Dissolved Metals (ug/L) } \\
\hline Arsenic & $<10$ & $<10$ & 24 & $<10$ & $<10$ \\
\hline Cadmium & $<1$ & $<1$ & $<1$ & 3 & $<1$ \\
\hline Lead & $<5$ & $<5$ & $<5$ & 90 & $<5$ \\
\hline Selenium & $<5$ & 9 & 54 & 26 & $<5$ \\
\hline Potassium & 1,040 & 733 & 113,000 & 1,380 & 782 \\
\hline \multicolumn{6}{|c|}{ Inorganic Compounds ( $\mu g / L)$} \\
\hline Nitrate/nitrite as $\mathrm{N}$ & 490 & 12,000 & $<50$ & $<50$ & 8,000 \\
\hline Sulfate & 54,000 & 105,000 & 362,000 & 93,000 & 94,000 \\
\hline Chloride & 4,800 & 23,000 & 304,000 & 866,000 & 24,000 \\
\hline Total phosphate as $\mathrm{P}$ & $\mathrm{NA}^{\mathrm{b}}$ & NA & NA & NA & NA \\
\hline Total dissolved solids & 125,000 & 328,000 & $1,403,000$ & $1,087,000$ & 262,000 \\
\hline \multicolumn{6}{|l|}{ Radioactivity (pCi/L) } \\
\hline Gross beta & 1.3 & 2.5 & 100 & $<4.8$ & 1.4 \\
\hline Potassium-40 & NA & NA & 120 & NA & NA \\
\hline Radium-226 & NA & NA & 0.43 & NA & NA \\
\hline \multicolumn{6}{|c|}{ Volatile Organic Compounds ( $\mu g / L)$} \\
\hline Benzene & $\mathrm{ND}^{\mathrm{c}}$ & ND & 6.0 & ND & ND \\
\hline Chlorobenzene & ND & ND & 980 & ND & ND \\
\hline Ethyl benzene & ND & ND & 3.0 & ND & ND \\
\hline Toluene & ND & ND & 5.0 & ND & ND \\
\hline Chloroform & ND & ND & 7.0 & 3.0 & ND \\
\hline Carbon tetrachloride & ND & 5.0 & ND & ND & ND \\
\hline $112 \mathrm{TCE}$ & ND & $\mathrm{ND}$ & 7.0 & 130 & $\mathrm{ND}$ \\
\hline TCLEA & ND & ND & ND & 200 & 5.0 \\
\hline Vinyl chloride & ND & ND & 550 & 48 & ND \\
\hline trans-12DCE & ND & ND & 2,220 & 8,500 & ND \\
\hline TRCLE & ND & ND & 980 & 6,700 & 5.0 \\
\hline TCLEE & ND & ND & 420 & ND & ND \\
\hline
\end{tabular}

a Includes all parameters that were detected at least once. Metals analyzed but not detected: barium $(<300 \mu \mathrm{g} / \mathrm{L})$, chromium $(<10 \mu \mathrm{g} / \mathrm{L})$, mercury $(<0.2 \mu \mathrm{g} / \mathrm{L})$, and silver $(<25 \mu \mathrm{g} / \mathrm{L})$.

b NA = not analyzed.

c $\mathrm{ND}=$ not detected.

Source: Nemeth (1989). 
TABLE 2.9 Analytical Results for Selected Inorganic Compounds, TOC, and Metals in Groundwater from the Toxic Burning Pits, 1990

\begin{tabular}{lccccccccc}
\hline Well & $\begin{array}{c}\text { Chloride } \\
(\mathrm{mg} / \mathrm{L})\end{array}$ & $\begin{array}{c}\text { Potassium } \\
(\mathrm{mg} / \mathrm{L})\end{array}$ & $\begin{array}{c}\text { TOC } \\
(\mathrm{mg} / \mathrm{L})\end{array}$ & $\begin{array}{c}\text { Arsenic } \\
(\mu \mathrm{g} / \mathrm{L})\end{array}$ & $\begin{array}{c}\text { Cyanide } \\
(\mu \mathrm{L} / \mathrm{L})\end{array}$ & $\begin{array}{c}\text { Lead } \\
(\mu \mathrm{g} / \mathrm{L})\end{array}$ & $\begin{array}{c}\text { Nickel } \\
(\mu \mathrm{g} / \mathrm{L})\end{array}$ & $\begin{array}{c}\text { Selenium } \\
(\mu \mathrm{g} / \mathrm{L})\end{array}$ & $\begin{array}{c}\text { Zinc } \\
(\mu \mathrm{g} / \mathrm{L})\end{array}$ \\
\hline P2 & $<100$ & $<50$ & $<10$ & $\mathrm{ND}$ & $\mathrm{ND}$ & $\mathrm{ND}$ & $\mathrm{ND}$ & 3.8 & ND \\
P3 & $<100$ & 61.8 & 25 & 30.2 & ND & ND & 61.9 & ND & ND \\
P4 & 390 & $<50$ & $<10$ & ND & ND & ND & ND & ND & 292 \\
P9 & $<100$ & $<50$ & $<10$ & ND & ND & 124 & ND & ND & ND \\
TH4 & $<100$ & $<50$ & $<10$ & ND & ND & ND & ND & 2.35 & ND \\
JF51 & $<100$ & 140 & $<10$ & ND & 13.9 & ND & ND & ND & ND \\
JF52 & $<100$ & $<50$ & $<10$ & ND & ND & ND & ND & ND & ND \\
JF53 & $<100$ & $<50$ & $<10$ & ND & ND & ND & 440 & ND & ND \\
JF61 & $<100$ & 98 & 160 & 8.03 & ND & ND & ND & ND & ND \\
JF62 & $<100$ & $<50$ & 10 & ND & ND & ND & ND & ND & ND \\
JF63 & 180 & $<50$ & 50 & 4.11 & ND & ND & ND & ND & ND \\
JF71 & $<100$ & 79 & $<10$ & 3.32 & ND & ND & ND & ND & ND \\
JF72 & $<100$ & $<50$ & 180 & ND & ND & ND & ND & 3.21 & ND \\
JF73 & $<100$ & $<50$ & $<10$ & 5.52 & ND & ND & ND & ND & ND \\
JF81 & 130 & $<50$ & $<10$ & ND & ND & ND & ND & ND & ND \\
JF82 & $<100$ & 74.7 & 100 & 20.4 & 88 & ND & ND & ND & ND \\
JF83 & 120 & $<50$ & $<10$ & 60 & ND & ND & ND & 6.18 & ND \\
\hline
\end{tabular}

a $\mathrm{ND}=$ not detected.

Source: USGS (1991). 
TABLE 2.10 Analytical Results for Selected VOCs in Groundwater from the Toxic Burning Pits Area, 1990

\begin{tabular}{|c|c|c|c|c|c|c|c|c|c|}
\hline \multirow[b]{2}{*}{ Well $^{\mathrm{a}}$} & \multicolumn{9}{|c|}{ VOC $^{b}$ Concentrations ( $\mu \mathrm{g} / \mathrm{L}$ ) } \\
\hline & $112 \mathrm{TCE}$ & 11DCE & $12 \mathrm{DCE}$ & $\mathrm{C} 2 \mathrm{H} 3 \mathrm{CL}$ & C6H6 & CHCL3 & TCLEA & TCLEE & TRCLE \\
\hline P2 & 4.02 & $\mathrm{ND}^{\mathrm{c}}$ & 10.2 & ND & ND & ND & 101 & ND & 440 \\
\hline TH4 & ND & ND & ND & ND & ND & ND & 3.73 & ND & ND \\
\hline JF53 & 110 & 8.04 & 850 & 132 & ND & ND & 3,500 & ND & 820 \\
\hline JF52 & 10 & ND & 420 & ND & ND & 2.2 & 34.3 & ND & 52 \\
\hline JF51 & ND & 3.79 & 430 & ND & ND & ND & ND & ND & 520 \\
\hline JF63 & ND & ND & 7.33 & ND & ND & 7.6 & ND & 17.6 & 600 \\
\hline JF62 & ND & ND & ND & ND & ND & ND & ND & ND & 2.7 \\
\hline JF61 & ND & ND & ND & ND & ND & ND & ND & ND & 1.8 \\
\hline JF73 & 67.3 & 6.81 & 7,150 & ND & ND & 2.9 & 340 & ND & 1,800 \\
\hline JF72 & ND & ND & 32.6 & ND & ND & 1.9 & ND & ND & 4.5 \\
\hline JF71 & ND & ND & ND & ND & ND & 24 & ND & ND & 7.3 \\
\hline JF83 & 7,100 & 19 & 7,150 & 56.3 & 4.88 & 50 & 250 & 1,000 & 4,900 \\
\hline JF82 & ND & 30.1 & 210 & ND & ND & 5.6 & ND & 47.2 & 1,400 \\
\hline JF81 & 7,100 & ND & 34.6 & ND & ND & ND & 290 & ND & 230 \\
\hline
\end{tabular}

a TBP wells not listed contained no VOCs, or traces of 111TCE, C2H5CL, CCL4, CH3CL, and C6H5CL. No data for wells P1, P3, P4, JF43, JF41.

b Installation Restoration Data Management System (IRDMS) acronyms are used for VOCs: 112TCE = 1,1,2-trichloroethane; 11DCE = 1,1-dichloroethylene; 12DCE = 1,2-dichloroethylene; C2H3CL = vinyl chloride; C6H6 = benzene; CHCL3 = chloroform; TCLEA = 1,1,2,2-tetrachloroethane; TCLEE = tetrachloroethylene; and TRCLE = trichloroethylene.

c $\mathrm{ND}=$ not detected.

Source: USGS (1991). 
JF73 and JF83. The data also show that some contamination extends down into the leaky confining unit and the confined aquifer $(1,400 \mu \mathrm{g} / \mathrm{L}$ TRCLE in the leaky confining unit [JF82] and 7,100 $\mu \mathrm{g} / \mathrm{L}$ 112TCE in the confined aquifer [JF81]). Because the well screens monitoring the confined aquifer are at depths of $70 \mathrm{ft}$ or more (well JF81 is screened at a depth of 120-123 ft), VOC contamination extends more than $100 \mathrm{ft}$ deep.

Because TRCLE was detected most often, the TRCLE data were used to create a contour map of contamination in the surficial aquifer (Figure 2.14). Those contours show that a plume of contaminated groundwater extends south of the TBP area to the shore and, possibly, into the bay. Additional data on VOC concentrations in the groundwater at locations farther south and closer to the shore are needed to determine if the plume in the surficial aquifer extends into the bay.

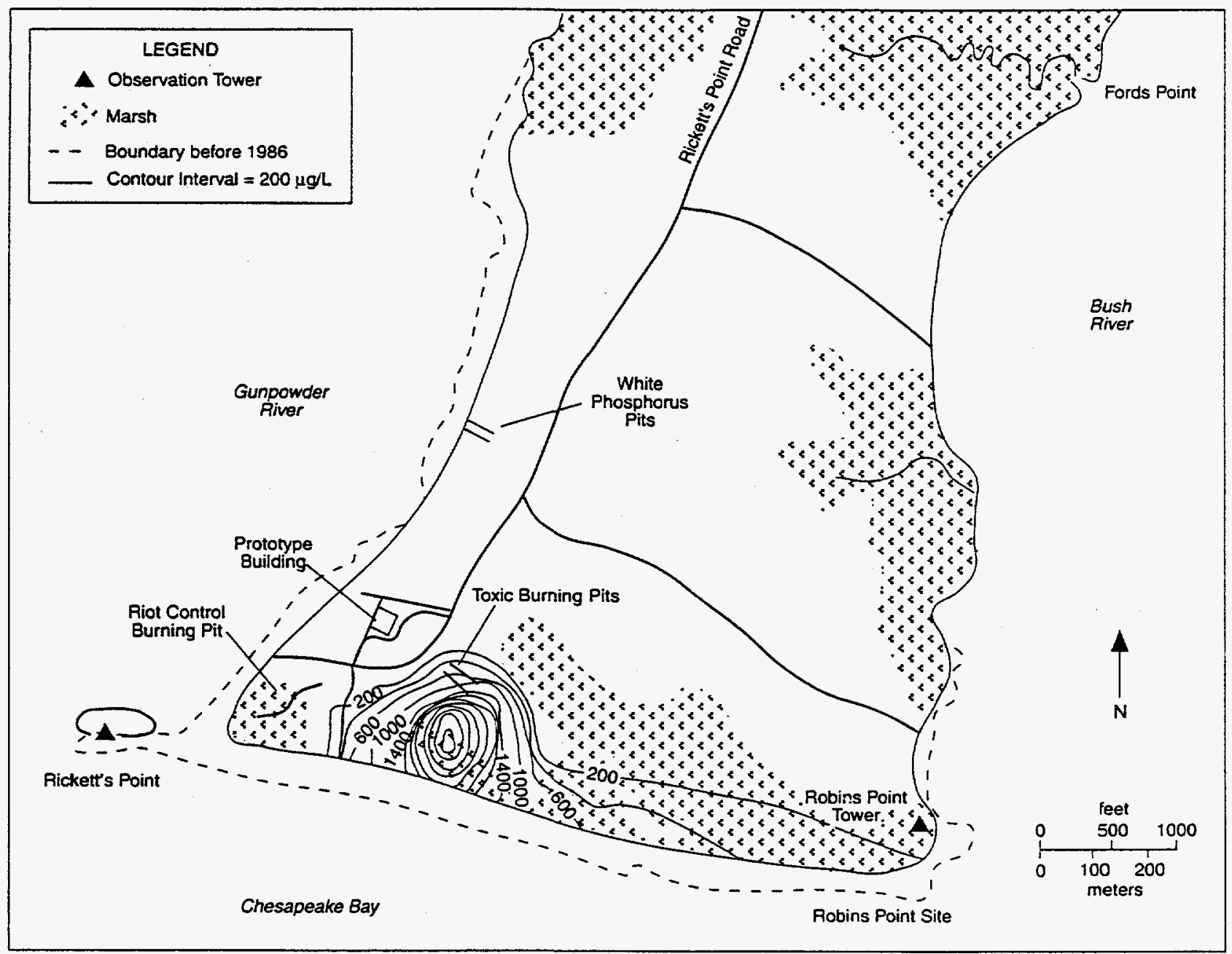

FIGURE 2.14 Contours of TRCLE Concentrations $(\mu \mathrm{g} / \mathrm{L}$ ) in the Surficial Aquifer (contour interval $=200 \mathrm{\mu g} / \mathrm{L}$ ) (Source: Adapted from Hughes 1993) 
Data for the single wells screened in the Potomac Group sediments (JF1 and JF2) indicate low concentrations of VOC contamination in the deeper strata. Well JF1 contained $2.25 \mu \mathrm{g} / \mathrm{L}$ 1,1,1-trichloroethane (111TCE) at a depth of $185-190 \mathrm{ft}$; well JF2 contained $6.7 \mu \mathrm{g} / \mathrm{L}$ TRCLE at 208-213 ft. These values are questionable because one of the two blanks associated with the sampling event contained detectable concentrations of TCLEA, TCLEE, and TRCLE.

Groundwater samples from a few wells were analyzed for explosives and organosulfur compounds. Results are summarized in Table 2.11. The data indicate some contamination with organosulfur compounds (including degradation products of mustard) in the surficial aquifer downgradient from the TBP. The maximum concentration was $140 \mu \mathrm{g} / \mathrm{L}$ 1,4-dithiane in well P3 just north of the western end of the TBP. No organosulfur

TABLE 2.11 Analytical Results for Organosulfur and Explosives-Related Compounds in Groundwater from the Toxic Burning Pits Area, 1990

\begin{tabular}{|c|c|c|c|c|c|}
\hline \multirow[b]{2}{*}{ Well } & \multicolumn{5}{|c|}{ Concentrations of Organosulfur Compounds ( $\mu \mathrm{g} / \mathrm{L}$ ) } \\
\hline & $\begin{array}{l}\text { 4-Chlorophenyl- } \\
\text { methsulfoxide }\end{array}$ & $\begin{array}{l}\text { 4-Chlorophenyl- } \\
\text { sulfone }\end{array}$ & 1,4-Dithiane & 1,4-Oxithiane & Thiodiglycol \\
\hline P3 & $\mathrm{ND}^{\mathrm{a}}$ & ND & 140 & ND & $N A^{b}$ \\
\hline P4 & ND & ND & 8.28 & ND & NA \\
\hline JF53 & ND & ND & 2.11 & $\mathrm{ND}$ & ND \\
\hline JF63 & ND & ND & 8.21 & 8.24 & 21 \\
\hline \multirow[t]{3}{*}{ JF83 } & ND & 20.5 & ND & ND & NA \\
\hline & \multicolumn{5}{|c|}{ Concentrations of Explosives-Related Compounds ( $\mu \mathrm{g} / \mathrm{L}$ ) } \\
\hline & $\mathrm{DNT}^{\mathrm{c}}$ & $\begin{array}{c}\text { Nitro- } \\
\text { benzene }\end{array}$ & $\begin{array}{l}\text { Nitro- } \\
\text { cellulose }\end{array}$ & PETN $^{d}$ & $\mathrm{RDX}^{\mathrm{e}}$ \\
\hline P9 & ND & ND & 226 & $\mathrm{ND}$ & 0.496 \\
\hline JF43 & ND & ND & 21.3 & ND & ND \\
\hline JF51 & ND & 0.0889 & ND & ND & ND \\
\hline JF63 & ND & ND & ND & 15.9 & ND \\
\hline JF73 & ND & ND & ND & ND & 1.18 \\
\hline
\end{tabular}

a $\mathrm{ND}=$ not detected.

b NA = no data available.

c DNT = dinitrotoluene.

d PETN = penta-erythritol tetranitrate.

e $\mathrm{RDX}=$ hexahydro-1,3,5-trinitro-1,3,4-triazine.

Source: USGS (1991). 
contamination was found in the middle or lower aquifers. Explosives-related compounds were also found in low concentrations (up to $226 \mu \mathrm{g} / \mathrm{L}$ nitrocellulose) in the water table and the lower aquifer. Because nitrocellulose is not soluble in water, this value is either lab error or due to suspended solids in the groundwater sample.

Concentrations of the radioactive species uranium, thorium-230, cesium-137, and strontium-90 were measured in monitoring wells P1, P3, P4, JF53, JF52, JF51, JF63, and JF73. Elevated concentrations of cesium-137 (up to $172 \mathrm{pCi} / \mathrm{L}$ ) and strontium-90 (up to $128 \mathrm{pCi} / \mathrm{L}$ ), measured as beta radiation, were found in wells P3, JF51, and JF73 (USGS 1991). If these values are confirmed by additional measurements, they would indicate the presence of radioactive contaminants.

In 1992, the USGS analyzed groundwater collected from wells in the TBP area (Figure 2.13) for VOCs (Table 2.12). The data indicate that VOCs are present in the three aquifers underlying J-Field (surficial unit, confining unit, and confined unit); that concentrations of TRCLE, TCLEE, TCLEA, chloroform (CHCL3), 12DCE, and 112TCE have increased significantly since 1990 (see also Table 2.10); and that concentrations of 1,1-dichloroethylene (11DCE) have not been detected.

TABLE 2.12 Analytical Results for Selected VOCs in Groundwater Samples from the Toxic Burning Pits Area, 1992

\begin{tabular}{lrrrrrr}
\hline & \multicolumn{7}{c}{ VOC Concentrations $(\mu \mathrm{g} / \mathrm{L})$} \\
\cline { 2 - 7 } Well $^{\mathrm{a}}$ & 112TCE & 12DCE & C2H3CL $^{\mathrm{b}}$ & TCLEA & TCLEE & TRCLE \\
\hline & & & & & \\
P3 & ND $^{\mathrm{c}}$ & 980 & 600 & ND & 3,400 & 570 \\
P4 & 65 & 3,300 & ND & ND & ND & 3,600 \\
P9 & ND & ND & 10 & ND & ND & ND \\
JF53 & 290 & 10,000 & 95 & 4,900 & ND & 4,200 \\
JF52 & 1 & 140 & ND & 1 & ND & 3 \\
JF51 & ND & 210 & ND & ND & ND & 97 \\
JF63 & ND & 120 & ND & 75 & 130 & 4,400 \\
JF62 & ND & 4 & ND & ND & ND & 13 \\
JF61 & ND & 2 & ND & ND & 2 & 10 \\
JF73 & 90 & 920 & ND & 9,000 & 280 & 5,100 \\
JF71 & ND & ND & ND & 2 & ND & 3 \\
JF83 & 2,000 & 12,000 & ND & 260,000 & 3,600 & 41,000 \\
JF82 & ND & 190 & ND & ND & ND & 1,800 \\
JF81 & ND & 22 & ND & 5 & 3 & 220 \\
\hline
\end{tabular}

a TBP wells not listed contained no VOCs. No data were obtained for wells P1, P2, JF43, 42, 41, and JF72.

b $\mathrm{C} 2 \mathrm{H} 3 \mathrm{CL}=$ vinyl chloride.

c $\mathrm{ND}=$ not detected.

Source: USGS (1992). 
The highest VOC concentrations were found in well clusters JF5, 6, 7, and 8 in all three aquifers. The greatest increases in concentrations were found in JF83, which monitors the surficial aquifer south of the main burning pits - TRCLE increased from 4,900 $\mu \mathrm{g} / \mathrm{L}$ in 1990 to $41,000 \mu \mathrm{g} / \mathrm{L}$ in 1992 , TCLEE increased from $1,000 \mu \mathrm{g} / \mathrm{L}$ to $3,600 \mu \mathrm{g} / \mathrm{L}$, TCLEA increased from $250 \mu \mathrm{g} / \mathrm{L}$ to $260,000 \mu \mathrm{g} / \mathrm{L}$, and $12 \mathrm{DCE}$ increased from $7,150 \mu \mathrm{g} / \mathrm{L}$ to $12,000 \mu \mathrm{g} / \mathrm{L}$. Concentrations of $112 \mathrm{TCE}$ decreased from $7,100 \mu \mathrm{g} / \mathrm{L}$ in 1990 to $2,000 \mu \mathrm{g} / \mathrm{L}$ in 1992 (USGS 1992).

\subsubsection{Potential Pathways of Contaminant Migration}

Existing data indicate that the main pathway of contaminant migration at the TBP $A O C$ is movement through the vadose zone down into the groundwater and then transport by groundwater.

Contaminants are apparently moving from their source, down into the groundwater, and then downgradient into the marshes by surficial aquifer discharge or into the estuaries by groundwater upwelling, or to locations even farther downgradient.

The direction of groundwater movement in the Talbot aquifers appears to be away from the TBP AOC toward the low-lying marshes and under the Gunpowder and Bush rivers. However, the lateral gradients in the lower aquifers are quite small (USGS 1991). The vertical movement of groundwater appears to be down through the aquifers; however, offshore there may be upward flow from each of the three Talbot aquifers into the Gunpowder and Bush rivers. Movement in the surficial and confined aquifers is affected by the tides (USGS 1991).

Surface water and associated sediment transport may play some role in contaminant migration in that surface runoff, particularly after intense storms, may carry dissolved and suspended contaminants from the contaminated areas into the marshes and estuaries. Surface water percolating through and leaching contaminated soils may be a major pathway by which contaminants, especially metals and VOCs, move down into the groundwater. Any contaminants that may have been present in the past in sufficient quantities to exist as free liquid in the soil would be expected to migrate down, independent of the presence of water.

Because of the generally humid conditions in the J-Field study area, wind transport of contaminated soil in areas with a good vegetative cover is expected to be minor. Diffusion of contaminated soil gas into the atmosphere and direct volatilization of contaminants from the soil are also expected to be minor release mechanisms. However, because portions of the TBP AOC are unvegetated or are sparsely covered with stressed vegetation, the air pathway may be significant and will be investigated. 


\subsubsection{White Phosphorus Burning Pits}

\subsubsection{Types of Waste Present}

The WPP area was used for the disposal of WP, PWP, and other related chemicals. It is also possible that riot control agents such as CN and TRCLE were disposed of in the WPP (Nemeth 1989).

\subsubsection{Types of Contaminants Present}

The first phase of the USGS hydrological assessment was conducted to select locations for monitoring wells at the TBP and WPP. It was assumed that the pits and the open burning grounds around them are the primary sources of contamination. The following subsections discuss the findings relative to the nature and extent of contamination in the WPP area.

\section{Soil Gas}

During Phase I of the hydrological assessment, the USGS sampled 35 locations around the WPP for soil-gas concentrations of TRCLE, TCLEE, combined hydrocarbons, and simple aromatics. The highest relative flux values of contamination were found north of the pits and to the west along the shore of Gunpowder River. Isolated areas of contamination were found to the south. The relative flux contours for TCLEE, shown in Figure 2.15, are similar to those for the other measured contaminants. However, the simple aromatics contamination north of the pits is more extensive than is shown in Figure 2.15 (Hughes 1993).

\section{Soil}

In 1983, soil samples were collected from each of the four monitor well boreholes at the WPP (Figure 2.16). For each borehole, one sample was obtained as a composite of samples collected over 5 -ft intervals. The samples were analyzed for metals, cyanide, phenols, total phosphorus, VOCs, pesticides, PCBs, and herbicides.

The only significant contamination found was lead, at $1,360 \mathrm{mg} / \mathrm{kg}$ in the sample from borehole JBP-4. Arsenic (10 mg/kg), barium (208 mg/kg), and possibly cadmium $(1.33 \mathrm{mg} / \mathrm{kg}$ ) were found in the same sample. No VOCs were found in any of the samples at a detection limit of $5 \mu \mathrm{g} / \mathrm{kg}$. Cyanide was not found at a detection limit of $20 \mu \mathrm{g} / \mathrm{kg}$. Samples from the other boreholes showed essentially no contamination (Princeton Aqua Science 1984). One composite sample was collected from each of the two main pits in the WPP AOC. The samples from the pits, along with background samples, were analyzed for several chemical parameters (Table 2.13). The results show significant levels of lead (up to $2,960 \mathrm{mg} / \mathrm{kg}$ ) and 


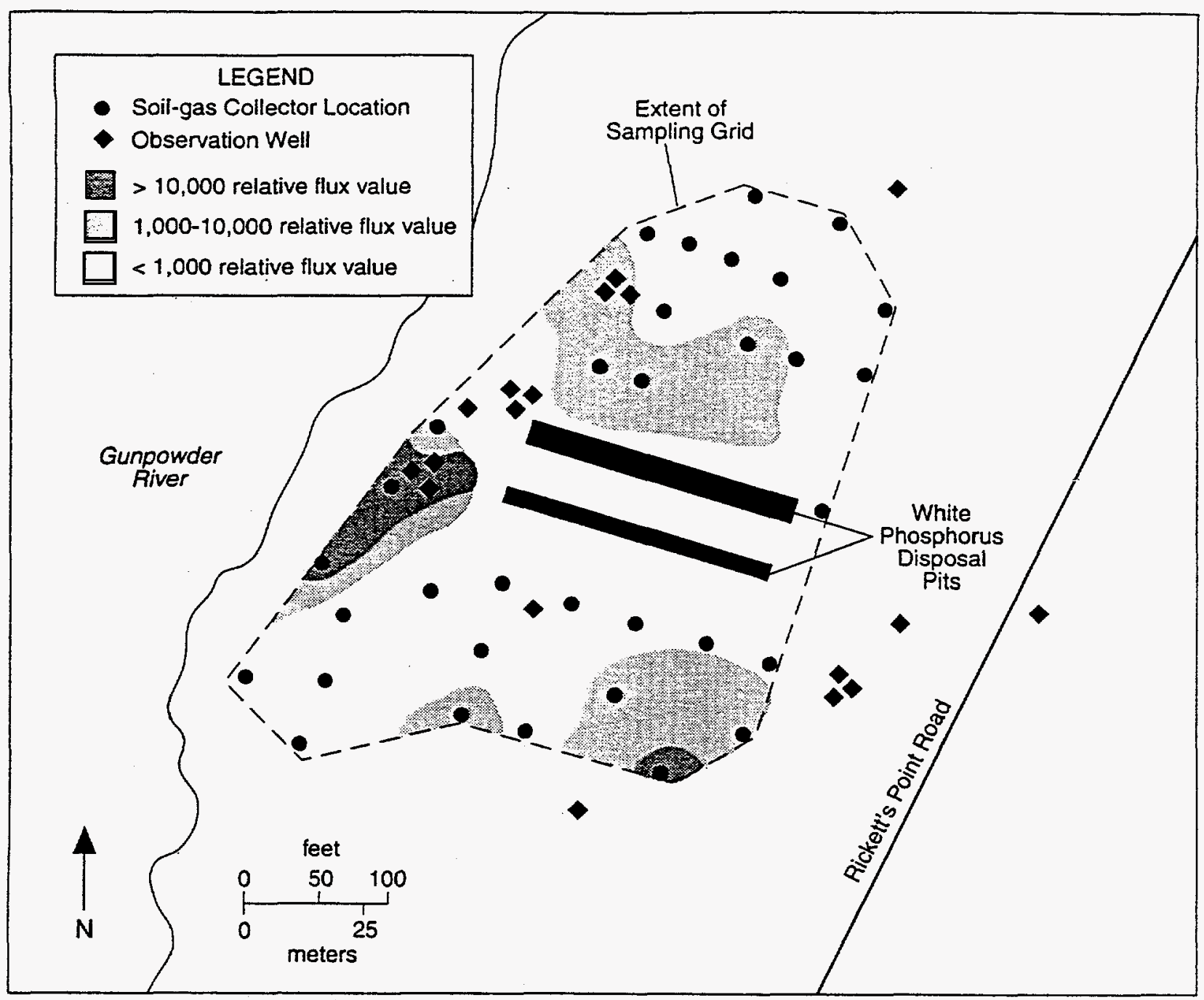

FIGURE 2.15 Relative Flux Contours for TCLEE at the White Phosphorus Pits (Source: Adapted from Hughes 1993)

zinc (up to $2,720 \mathrm{mg} / \mathrm{kg}$ ) in each sample. High concentrations of petroleum hydrocarbons (up to $5,800 \mathrm{mg} / \mathrm{kg}$ ) were also detected. The elevated levels of petroleum hydrocarbons in the background samples $(62 \mathrm{mg} / \mathrm{kg}$ ) indicate that these samples were collected at contaminated locations. Elevated levels of phosphorus (up to $1,573 \mathrm{mg} / \mathrm{kg}$ ) were also detected in the WPP samples.

As part of the 1986 RFA (Nemeth 1989), surface soil samples were collected at two locations (31 and 32) in and around the WPP. Figure 2.17 shows the sampling locations. The samples were analyzed for metals, extractable metals, and explosives-related compounds. The results, as summarized in Table 2.14, show that the surface soil in and around the WPP contained elevated levels of metals, especially lead (up to $255 \mathrm{mg} / \mathrm{kg}$ ), chromium (up to $28.9 \mathrm{mg} / \mathrm{kg}$ ), cadmium (up to $2.40 \mathrm{mg} / \mathrm{kg}$ ), and barium (up to $149 \mathrm{mg} / \mathrm{kg}$ ). Neither of the two samples exceeded the RCRA EP limits for metals. 


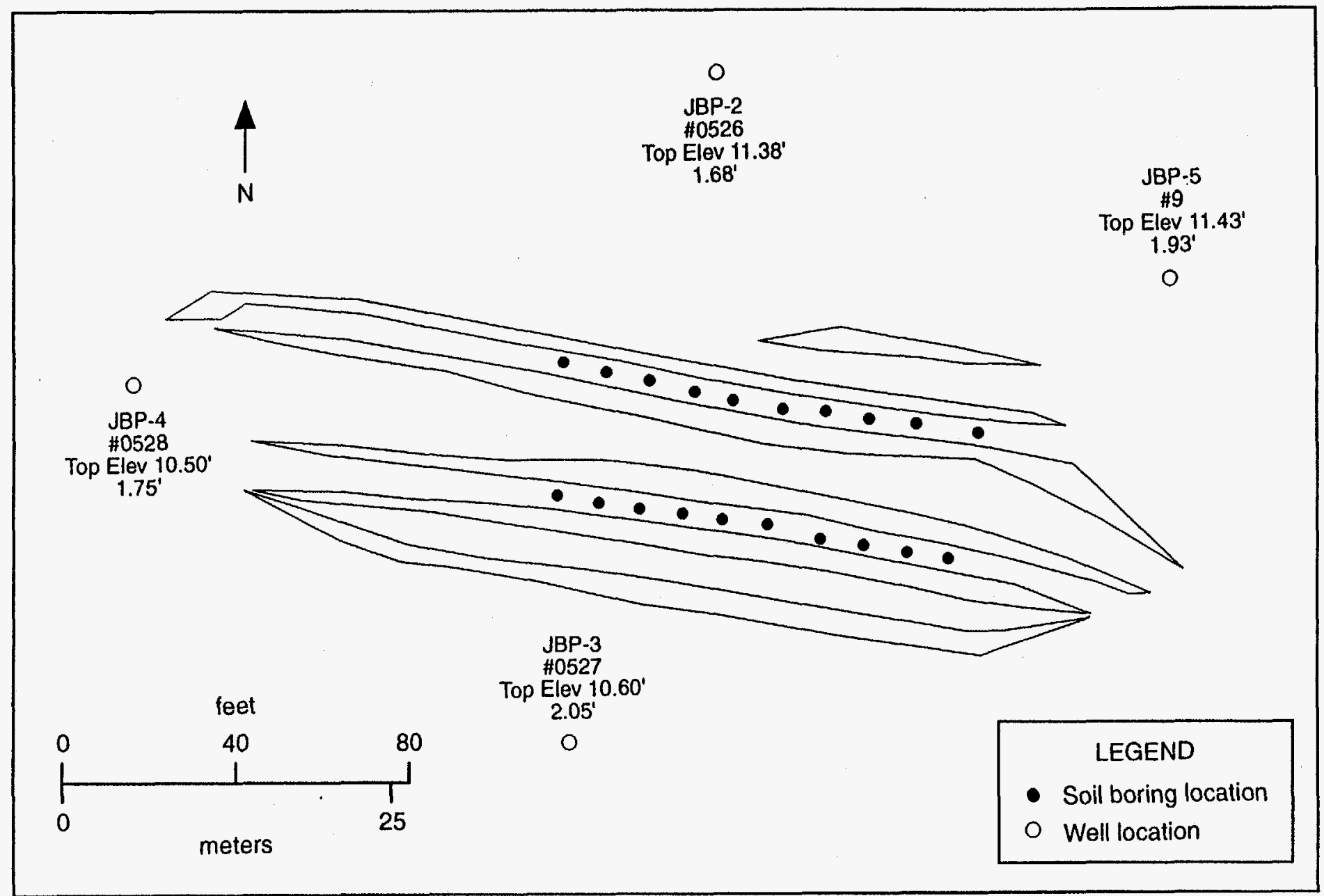

FIGURE 2.16 Locations of Soil Borings at the White Phosphorus Pits (Source: Adapted from Princeton Aqua Science 1984) 
TABLE 2.13 Concentrations of Chemical Parameters in Soil from the White Phosphorus Pits at J-Field

\begin{tabular}{|c|c|c|c|}
\hline \multirow[b]{2}{*}{ Parameter $^{\mathbf{a}}$} & \multicolumn{3}{|c|}{ Concentration $^{\mathrm{b}}$ ( $\mathrm{mg} / \mathrm{kg}$, unless noted) } \\
\hline & Background $^{c}$ & Pit $1^{d}$ & Pit $2^{\mathrm{d}}$ \\
\hline Arsenic & 1.46 & 2.93 & 0.915 \\
\hline Barium & 247 & 939 & 525 \\
\hline Cadmium & 0.519 & 6.70 & 2.74 \\
\hline Chromium & 34.3 & 203 & 183 \\
\hline Iron & 14,800 & 18,100 & 17,900 \\
\hline Lead & 889 & 2,960 & 1,310 \\
\hline Manganese & 267 & 260 & 197 \\
\hline Mercury & 0.042 & 0.037 & 0.065 \\
\hline Potassium & 2,420 & 2,260 & 2,520 \\
\hline Zinc & 45.4 & 2,530 & 2,720 \\
\hline $\mathrm{pH}$ (standard units) & 6.9 & 7.7 & 6.8 \\
\hline Nitrate & 202 & 498 & 136 \\
\hline Total phosphorus & 26 & 220 & 1,573 \\
\hline Cyanide & $<0.5$ & $<0.5$ & 0.77 \\
\hline Petroleum hydrocarbons & 62 & 2,260 & 5,800 \\
\hline Phenols & $<0.130$ & $<0.134$ & 0.636 \\
\hline \multicolumn{4}{|l|}{ Aromatics } \\
\hline Toluene $(\mu \mathrm{g} / \mathrm{kg})$ & 45.8 & 75.6 & 27.4 \\
\hline Ethylbenzene $(\mu \mathrm{g} / \mathrm{kg})$ & $<20$ & $<20$ & 51.6 \\
\hline
\end{tabular}

a Table lists parameters detected in at least one sample.

Parameters measured but not detected are other aromatics ( $<20 \mu \mathrm{g} / \mathrm{kg})$, VOCs $(<10 \mu \mathrm{g} / \mathrm{kg})$, herbicides $(<10 \mu \mathrm{g} / \mathrm{kg})$, pesticides $(<20 \mu \mathrm{g} / \mathrm{kg})$, and PCBs $(<10,000 \mu \mathrm{g} / \mathrm{kg})$.

b Results are based on composite soil samples taken in January 1983.

c Locations of background samples not given.

d Based on available information, it is inferred that Pit 1 is the northern pit and Pit 2 is the southern pit.

Source: Adapted from Princeton Aqua Science (1984). 


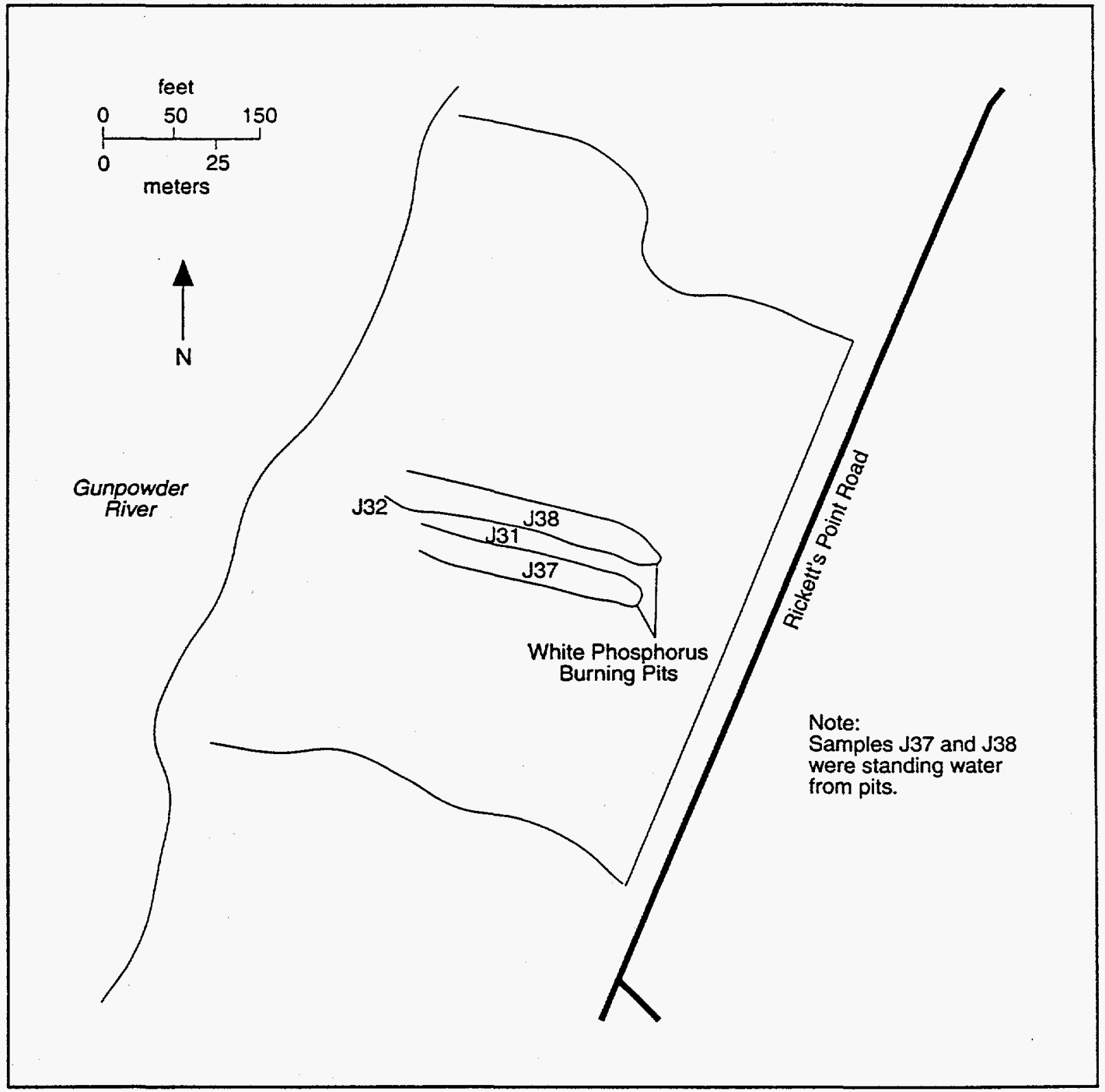

FIGURE 2.17 Locations of Surface Soil (J31 and J32) and Surface Water Samples (J37 and J38) in the White Phosphorus Pits Area (Source: Adapted from Hughes 1993) 
The USGS collected soil samples (at approximately 1-ft depths) from 36 sites in J-Field, including the WPP area (Figure 2.15). The samples were analyzed for indicator parameters, metals, VOCs, semivolatile compounds, and explosives (Hughes 1992). The results are presented in Table 2.15. Levels of metals were fairly low, except that at location 1 (just east of the pits), the concentration of zinc was $942 \mathrm{mg} / \mathrm{kg}$. No VOCs were detected.

Soil samples were also collected in the WPP area by Weston in October 1992. Samples were collected at depths of 2 and $4 \mathrm{ft}$ in the pits and at depths of $3 \mathrm{in}$. and $1 \mathrm{ft}$ in the marshes and pushout areas. Table 2.16 summarizes the analytic results for parameters detected in some of these samples.
TABLE 2.14 Analytical Results for Soil Samples J31 and J32 from the White Phosphorus Pits, 1986

\begin{tabular}{|c|c|c|}
\hline Parameter $^{\mathbf{a}}$ & J31 & J32 \\
\hline \multicolumn{3}{|c|}{ Total Metals (mg/kg) } \\
\hline Arsenic & 14.1 & 12.3 \\
\hline Barium & 141 & 149 \\
\hline Cadmium & 2.46 & 2.40 \\
\hline Chromium & 28.9 & 18.1 \\
\hline Lead & 255 & 184 \\
\hline Mercury & $<0.10$ & 0.14 \\
\hline Silver & $<1.00$ & $<5.00$ \\
\hline \multicolumn{3}{|c|}{ Extractable Metals (mg/L) } \\
\hline Barium & $<10.0$ & $<10.0$ \\
\hline Cadmium & $<0.10$ & $<0.10$ \\
\hline Chromium & $<0.50$ & $<0.50$ \\
\hline Lead & $<0.50$ & $<0.50$ \\
\hline
\end{tabular}

Source: Nemeth (1989)

\section{Surface Water}

Surface water samples (J37 and J38) were collected from the WPP area as part of the 1986 RFA (Nemeth 1989). Sampling locations are shown in Figure 2.17. Samples were analyzed for metals, explosives-related compounds, inorganic compounds, gross alpha and beta, VOCs, BNAs, pesticides, and PCBs. The results are summarized in Table 2.17 for locations J37 and J38.

The surface water contained some lead contamination. Sulfate and total dissolved solids (TDS) were slightly elevated in the WPP surface water, and gross alpha was also slightly elevated. None of the values for the other radioactive parameters was indicative of contamination.

Surface water samples were collected by the USGS at low tide close to the J-Field shore in the Gunpowder River (four locations near the WPP). One sample was collected onshore in a drainage ditch. Locations are shown in Figure 2.11. Both filtered and unfiltered samples were analyzed for water quality parameters, metals, and a few organic compounds. A sample taken at location $3 \mathrm{had}$ nitrate concentrations of $380 \mathrm{\mu g} / \mathrm{L}$. The metals data showed low concentrations of lead (ND to $28 \mu \mathrm{g} / \mathrm{L}$ ) and zinc (50 to $133 \mu \mathrm{g} / \mathrm{L}$ ) at locations 1 to 4 . Mercury and nickel concentrations were slightly elevated at location $1(0.54$ and $33.7 \mu \mathrm{g} / \mathrm{L}$, respectively). No evidence was found of arsenic, barium, or chromium contamination. Comparison of data for filtered and unfiltered samples indicates that the slightly elevated metals concentrations may be associated with the suspended solids in the samples. This conclusion is based on the lower concentrations of metals in filtered samples for the few locations where both filtered and unfiltered data were obtained (Hughes 1993). 
TABLE 2.15 Analytical Results for Soil Samples from the White Phosphorus Pits Area, April 1991

\begin{tabular}{|c|c|c|c|c|c|c|c|c|c|c|}
\hline \multirow[b]{2}{*}{ Parameter } & \multicolumn{10}{|c|}{ Concentrations by Soil Sample Location } \\
\hline & 1 & 2 & 3 & 4 & 5 & 6 & 7 & 8 & 9 & 10 \\
\hline \multicolumn{11}{|l|}{ Metals (mg/kg) } \\
\hline Arsenic & 4.2 & 2.7 & 2.8 & 2.3 & $\mathrm{ND}^{\mathrm{a}}$ & ND & ND & ND & 2.9 & 2.9 \\
\hline Cadmium & ND & ND & ND & ND & ND & ND & ND & ND & ND & ND \\
\hline Chromium & 16 & 12 & 12 & 8.9 & 9.6 & 8.8 & 11 & 9.7 & 13 & 11 \\
\hline Copper & 42 & 3.8 & 20 & 3.6 & 5.0 & 4.7 & 11 & 6.1 & 6.3 & 9.9 \\
\hline Lead & ND & 25 & 41 & 5.3 & 19 & 18 & 15 & 18 & 15 & 17 \\
\hline Antimony & ND & ND & ND & ND & ND & ND & ND & ND & ND & ND \\
\hline Zinc & 942 & ND & ND & 18 & ND & ND & ND & ND & ND & 26 \\
\hline \multicolumn{11}{|c|}{ Volatile Organic Compounds ( $\mu \mathrm{g} / \mathrm{kg})$} \\
\hline Acetone & ND & ND & ND & ND & ND & ND & ND & ND & ND & ND \\
\hline Trichloroethylene & ND & ND & ND & ND & ND & ND & ND & ND & ND & ND \\
\hline \multicolumn{11}{|c|}{ Semivolatile Organic Compounds ( $\mu \mathrm{g} / \mathrm{kg}$ ) } \\
\hline Butylbenzyl phthalate & ND & ND & ND & ND & ND & ND & ND & ND & ND & ND \\
\hline Benzoic acid & ND & ND & ND & ND & ND & ND & ND & ND & ND & ND \\
\hline Di-n-butyl phthalate & 4,830 & ND & ND & ND & ND & ND & ND & ND & ND & ND \\
\hline
\end{tabular}


TABLE 2.16 Analytical Results for TCL and TAL Analytes in Selected Soil Samples from the White Phosphorus Pits, 1992 $^{\mathrm{a}}$

\begin{tabular}{|c|c|c|c|c|c|c|}
\hline \multirow[b]{2}{*}{ Parameter } & \multicolumn{6}{|c|}{ Concentrations by Soil Sample Location } \\
\hline & JWP1-E $\left(2^{\prime}\right)^{b}$ & JWP1-E(4') & JWP2-E(2') & JWP2-E $\left(4^{\prime}\right)$ & JWPM-A(3") & JWPM-A(1') \\
\hline \multicolumn{7}{|c|}{ Volatile Organic Compounds ( $\mu \mathrm{g} / \mathrm{kg})$} \\
\hline Methylene chloride & $\mathrm{ND}^{\mathrm{c}}$ & ND & 9.53 & 15.2 & 13.4 & ND \\
\hline Acetone & 494 & 156 & 165 & 38.9 & 185 & 21.5 \\
\hline Toluene & ND & ND & ND & ND & ND & ND \\
\hline Xylenes & ND & 16.6 & ND & ND & 11.2 & 9.17 \\
\hline \multicolumn{7}{|l|}{ PCBs ( $\mu g / k g)$} \\
\hline Aroclor 1254 & ND & ND & ND & ND & ND & ND \\
\hline Aroclor 1260 & ND & ND & ND & ND & ND & ND \\
\hline \multicolumn{7}{|l|}{ TAL Analytes (mg/kg) } \\
\hline Antimony & ND & ND & ND & ND & 5.92 & ND \\
\hline Arsenic & 3.22 & 2.24 & 2.82 & ND & 4.20 & 2.46 \\
\hline Beryllium & 0.279 & 0.796 & 0.520 & ND & 0.318 & 0.335 \\
\hline Cadmium & ND & 0.626 & ND & $\mathrm{ND}$ & 2.02 & ND \\
\hline Chromium & 11.6 & 12.8 & 16.7 & 4.93 & 15.8 & 7.53 \\
\hline Cobalt & $\mathrm{ND}$ & ND & ND & ND & ND & $\mathrm{ND}$ \\
\hline Copper & 10.5 & 8.63 & 8.40 & ND & 59.4 & 11.0 \\
\hline Lead & 8.37 & 8.87 & 6.46 & 4.89 & 209 & 44.3 \\
\hline Zinc & 24.0 & 62.5 & 13.0 & 19.7 & 284 & 37.9 \\
\hline Nickel & ND & 13.7 & ND & 6.18 & ND & ND \\
\hline
\end{tabular}




\begin{tabular}{|c|c|c|c|c|c|c|}
\hline \multirow[b]{2}{*}{ Parameter } & \multicolumn{6}{|c|}{ Concentrations by Soil Sample Location } \\
\hline & JWPM-C(3") & JWPM-C(1') & JWPP-A(3") & JWPP-A(1) & JWPP-C(3") & JWPP-C(1') \\
\hline \multicolumn{7}{|c|}{ 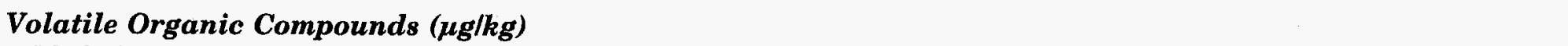 } \\
\hline Methylene chloride & 10.8 & 5.83 & 17.0 & 7.51 & 9.29 & 8.35 \\
\hline Acetone & 16.1 & 45.0 & ND & 252 & ND & 178 \\
\hline Toluene & 7.42 & ND & ND & ND & ND & 6.54 \\
\hline Xylenes & 18.4 & ND & ND & ND & ND & 11.8 \\
\hline \multicolumn{7}{|l|}{ PCBs ( $\mu g / k g)$} \\
\hline Aroclor 1254 & ND & ND & ND & ND & 323 & ND \\
\hline Aroclor 1260 & 215 & ND & ND & ND & ND & ND \\
\hline \multicolumn{7}{|l|}{ TAL Analytes (mg/kg) } \\
\hline Antimony & ND & ND & ND & ND & 10.2 & ND \\
\hline Arsenic & 4.00 & 1.96 & 4.48 & 2.60 & 3.29 & 3.55 \\
\hline Beryllium & 0.239 & 0.182 & 0.254 & 0.218 & 0.267 & 0.308 \\
\hline Cadmium & 2.11 & ND & ND & ND & 1.62 & 0.576 \\
\hline Chromium & 20.8 & 8.37 & 12.4 & 10.6 & 21.9 & 9.83 \\
\hline Cobalt & ND & ND & ND & ND & ND & ND \\
\hline Copper & 111 & ND & 10.4 & ND & 109 & 19.8 \\
\hline Lead & 556 & 7.29 & 23.2 & 25.0 & 235 & 156 \\
\hline Zinc & 15.2 & 7.57 & 109 & 34.9 & 651 & 257 \\
\hline Nickel & 1,080 & 24.6 & 8.27 & 8.18 & 9.65 & 9.47 \\
\hline
\end{tabular}

a Only detected analytes are reported; for samples with duplicate analyses, the higher value is reported.

b Sample depth shown in parentheses.

c $\mathrm{ND}=$ not detected.

Source: Mazelon (1993). 
TABLE 2.17 Analytical Results for Surface Water Samples from the White Phosphorus Pits Area, 1986

\begin{tabular}{|c|c|c|}
\hline \multirow[b]{2}{*}{ Parameter } & \multicolumn{2}{|c|}{ Location } \\
\hline & J37 & J38 \\
\hline \multicolumn{3}{|l|}{ Dissolved Metals ( $\mu g / L)$} \\
\hline Cadmium & $<1.0$ & 3.0 \\
\hline Lead & 6.0 & 44 \\
\hline Mercury & $<0.20$ & $<0.20$ \\
\hline \multicolumn{3}{|c|}{ Inorganic Compounds ( $\mu g / L)$} \\
\hline Nitrate and nitrite as $\mathrm{N}$ & $<30$ & 200 \\
\hline Sulfate & 160,000 & 15,000 \\
\hline Chloride & 5,000 & 3,000 \\
\hline Total dissolved solids & 388,000 & 114,000 \\
\hline \multicolumn{3}{|l|}{ Radioactivity (pCi/L) } \\
\hline Gross alpha & 2.8 & 4.2 \\
\hline Gross beta & 8.0 & 8.7 \\
\hline
\end{tabular}

Source: Nemeth (1989).

A few organic constituents (acetone, toluene, phenol, TOC, and TOX) were measured in samples from two locations. TOC and TOX were detected in the unfiltered samples only (4,000 and $21.6 \mu \mathrm{g} / \mathrm{L}$, respectively). Toluene was found only at location $1(3.05 \mu \mathrm{g} / \mathrm{L})$ (Hughes 1993).

In general, the nearshore surface water samples collected to date show little contamination. What contamination there is appears to be associated with the suspended solids. This suggests that the nearshore sediments may be contaminated. Additional data are needed to evaluate this situation. No data are available on concentrations of pollutants in surface water or sediments in the marshes on J-Field.

\section{Groundwater}

Three monitoring wells (designated TH) were installed at the WPP in 1977 (Figure 2.13) as part of an environmental contamination survey conducted by USATHAMA (Nemeth 1989). The depth of the wells ranged from 20 to $25 \mathrm{ft}$. The wells were screened in the surficial aquifer (Sonntag 1991). Water samples collected from the wells in 1977 were analyzed for metals, indicator chemicals, WP, mustard degradation products, cholinesterase inhibitors, BNAs, and VOCs.

Low levels of organic contamination were found in all wells. A mustard degradation product, 1,3-dithiane, was found at a concentration of $6 \mu \mathrm{g} / \mathrm{L}$ in well TH1 near the WPP. 
Aliphatic and aromatic organic compounds were found at levels up to $200 \mu \mathrm{g} / \mathrm{L}$ in most well samples. Organic compounds introduced by the well construction procedure or possible sample contamination were found at higher concentrations (e.g., tetrahydrofuran up to $8,000 \mu \mathrm{g} / \mathrm{L})$.

Four additional wells were installed around the WPP (wells P5-P8 in Figure 2.13) as part of a munitions disposal study (Princeton Aqua Science 1984). The wells were 17-20 ft deep and were screened with 15-ft-long screens in the surficial aquifer (Sonntag 1991). Samples collected from the wells in 1983 were analyzed for metals, nitrate, TOX, TOC, radioactivity, some pesticides and herbicides, and secondary drinking water contaminants. Analyses indicated no major concentrations of metals, pesticides, or herbicides.

Samples collected from these four wells in 1986 as part of an RFA (Nemeth 1989) were analyzed for metals, explosives-related compounds, indicator parameters, radioactivity, thiodiglycol, VOCs, BNAs, pesticides, and PCBs. Sulfate, TDS, and TRCLE were the only parameters that showed any elevated concentrations.

Twelve additional monitoring wells were installed at the WPP in late 1988 and 1989 by the USGS (Sonntag 1991; Hughes 1993). The wells were installed as three-well nests at four different locations (Figure 2.13). At each site, the three wells were screened in the confined aquifer, the leaky confined unit, and the surficial aquifer of the Talbot Formation. The groundwater samples collected from the nested wells were analyzed for metals, other inorganic parameters, VOCs, and semivolatile organic compounds. Some analyses were performed for organosulfur, explosives-related, and radioactive compounds. Wells were selected for these analyses on the basis of their proximity to potential disposal areas for these materials (USGS 1991).

Potassium concentrations detected in the samples varied considerably, with most ranging from ND to $10 \mu \mathrm{g} / \mathrm{L}$. All of the elevated values (above $50 \mu \mathrm{g} / \mathrm{L}$ ) occurred in the leaky confined unit or the confined aquifer. Movement of sea water into the groundwater does not appear to be the source of the potassium, because wells with elevated potassium concentrations did not have elevated chloride concentrations.

Low levels of VOC contamination were detected in the WPP. Only one well, P8, showed contamination by TRCLE $(40 \mu \mathrm{g} / \mathrm{L})$. Some contamination by other VOCs was detected in wells P7 and JF10-2. (Acetone is excluded because of the possibility that its presence is a result of laboratory quality control $[\mathrm{QC}]$ procedures.)

\subsubsection{Potential Pathways of Contaminant Migration}

Existing data indicate that the main pathway of contaminant migration at the WPP $\mathrm{AOC}$ is movement through the vadose zone down into the groundwater and then transport by the groundwater. 
The direction of groundwater movement in the Talbot aquifers appears to be away from the WPP AOC toward the Gunpowder River. However, the lateral gradients in the lower aquifers are quite small (USGS 1991). The vertical movement of groundwater appears to be down through the aquifers; however, offshore there may be upward flow from each of the three Talbot aquifers into the Gunpowder and Bush rivers. Movement in the surficial and confined aquifers is affected by the tides (USGS 1991).

Surface water and associated sediment transport may play some role in contaminant migration in that surface runoff, particularly after intense storms, may carry dissolved and suspended contaminants from the contaminated areas into the marshes and estuaries. Lateral contaminant migration by surface water is expected to be minor (Sonntag 1991). However, in the past, the surface water pathway may have been more significant because the pits were operated to allow drainage to flow to the Gunpowder River (Weston 1992). Surface water percolating through and leaching contaminated soils may be a major pathway by which contaminants, especially metals and VOCs, move down into the groundwater. Any contaminants that may have been present in the past in sufficient amounts to exist as free liquid in the soil would be expected to migrate downward, independent of the presence of water.

Because of the generally humid conditions in the J-Field study area, wind transport of contaminated soil in areas with a good vegetative cover is expected to be minor. Diffusion of contaminated soil gas into the atmosphere and direct volatilization of contaminants from the soil are also expected to be minor release mechanisms. However, because portions of the WPP AOC are unvegetated or are sparsely covered with stressed vegetation, and because at least part of the WPP AOC is expected to be used for OB/OD, the air pathway may be significant and will be investigated.

\subsubsection{Riot Control Burning Pit}

\subsubsection{Types of Waste Present}

The RCP area was used for burning of riot control agents and disposing of munitions filled with riot control agents and of materials contaminated with these chemicals. The primary riot control chemicals disposed of in the burning pit were tear agents (CS and possibly $\mathrm{CN}$ ) and items contaminated with those agents.

\subsubsection{Types of Contaminants Present}

\section{Soil Gas}

Soil-gas sampling and analysis were conducted during Phase I of the USGS hydrological assessment. Soil-gas samples collected from 12 locations on a 100 -ft grid around the RCP were analyzed for TRCLE, TCLEE, alkanes, combined hydrocarbons, and simple 
aromatics. Relative flux values indicated contamination by chlorinated solvents at areas north and south of the pits. Contamination by phthalates and heavy aromatic compounds appeared to be more extensive, with phthalates showing elevated contamination along Rickett's Point Road and at one location south of the pit. The highest measured flux value for aromatic compounds was at a location south of the pit. Figure 2.18 shows the relative flux contours for heavy aromatics at the pit.

\section{Soil}

A soil sample was collected immediately northeast of the disposal trench during the 1986 RFA (Nemeth 1989). That sample contained a significant amount of ash and other residue from burning operations; analysis showed slightly elevated levels of total cadmium, chromium, lead, and silver, and very low levels of polyaromatic hydrocarbons (PAHs).

Soil samples were collected by the USGS at 36 sites at J-Field, including the RCP area (locations 16 through 20 in Figure 2.9). The samples were collected at 1 -ft depths and were analyzed for indicator parameters, metals, VOCs, semivolatile compounds, and explosives-related compounds (Hughes 1992). The results of the analyses are presented in Table 2.18. Soil samples showed some metals contamination, especially at locations 16,17 , and 18 north of the pit, where lead concentrations ranged from 34 to $68 \mathrm{mg} / \mathrm{kg}$. Zinc was found at $158 \mathrm{mg} / \mathrm{kg}$ at location 16. Organic compounds (acetone, butylbenzyl phthalate, and benzoic acid) were also detected in some samples.

Soil samples were also collected in the RCP area by Weston in October 1992 (Figure 2.19). The samples were collected at 3-in., 2-ft, and 4-ft depths in the pit and at 3-in. and 1- $\mathrm{ft}$ depths in the marshes and pushout areas. Tables 2.19 and 2.20 summarize the analytic results for parameters detected in some of these samples. The data indicate that several areas are contaminated with metals, mainly at the surface (within 3 in. to $2 \mathrm{ft}$ ). The highest concentrations of lead were found in the center of the RCP (up to $339 \mathrm{mg} / \mathrm{kg}$ at $3 \mathrm{in}$.). Lead concentrations ranged from 31 to $90 \mathrm{mg} / \mathrm{kg}$ at the ends of the pit, in the marshes, and in the pushout areas. Other metals detected include beryllium, up to $0.451 \mathrm{mg} / \mathrm{kg}$ in the marsh east of the RCP; chromium, up to $106 \mathrm{mg} / \mathrm{kg}$ at the eastern end of the RCP; copper, up to $742 \mathrm{mg} / \mathrm{kg}$ at the eastern end of the RCP; and zinc, up to $742 \mathrm{mg} / \mathrm{kg}$ in the center of the RCP. Organic compounds were also detected, including benzoic acid, chlorobenzene, di-nbutyl phthalate, acetone, methylene chloride, styrene, toluene, xylene, and pesticides. PCBs were not detected.

\section{Surface Water}

Surface water samples were collected by the USGS at low tide close to the shore near the RCP area (locations 7-12 in Figure 2.11). Both filtered and unfiltered samples were analyzed for major water quality parameters, metals, and a few organic compounds. Nitrate concentrations from location 7 ranged from 200 to $400 \mu \mathrm{g} / \mathrm{L}$. Phenol, TOC, and TOX were 


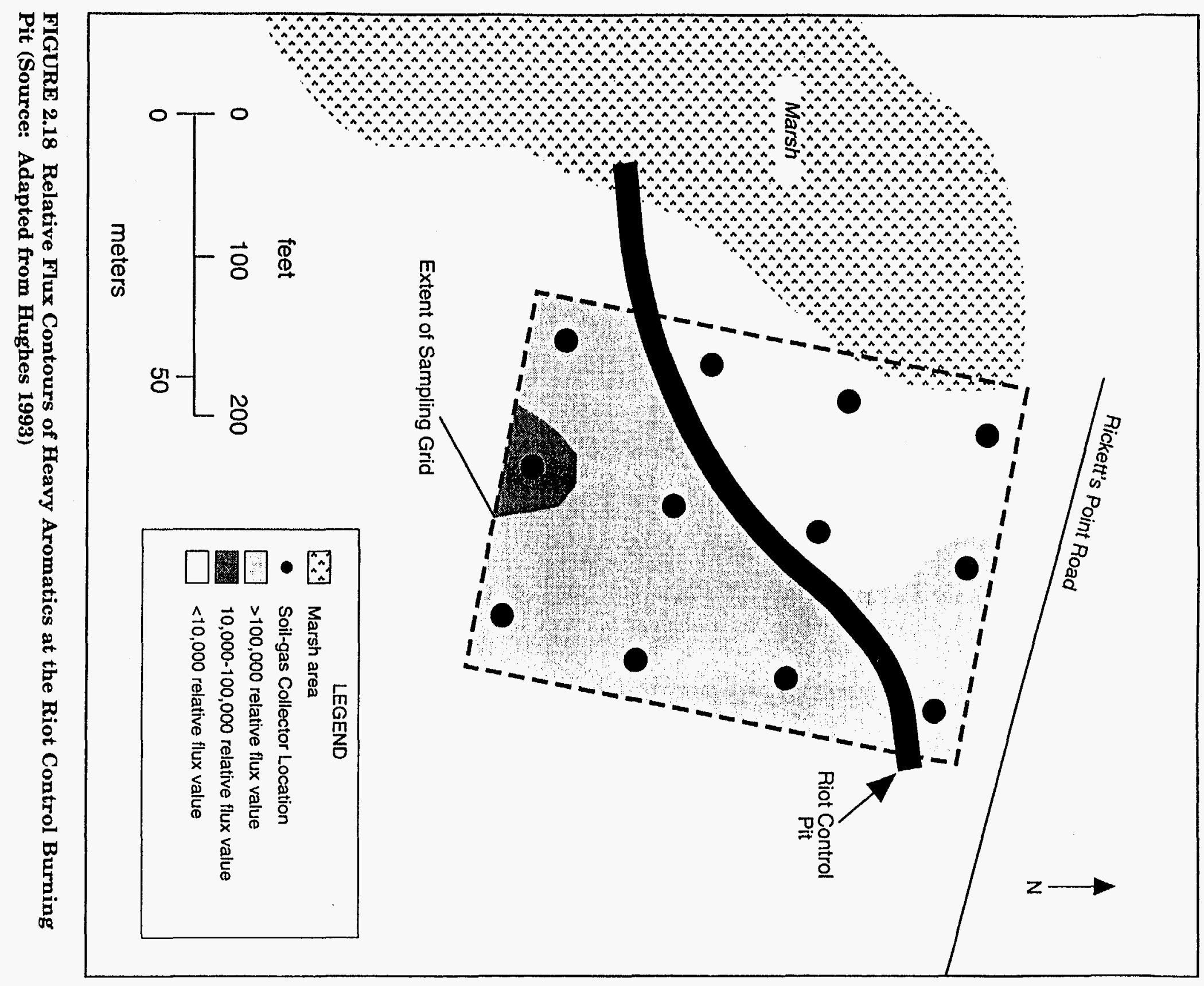


TABLE 2.18 Analytical Results for Soil Samples from the Riot Control Burning Pit Area, April 1991

\begin{tabular}{|c|c|c|c|c|c|c|c|}
\hline \multirow[b]{2}{*}{ Parameter } & \multicolumn{7}{|c|}{ Concentration by Soil Sample Location } \\
\hline & 16 & 17 & 18 & 19 & 20 & 21 & 22 \\
\hline \multicolumn{8}{|l|}{ Metals (mg/kg) } \\
\hline Arsenic & 4.4 & 3.8 & 3.4 & 2.9 & 3.7 & 3.3 & $\mathrm{ND}^{\mathrm{a}}$ \\
\hline Cadmium & ND & ND & ND & ND & ND & ND & ND \\
\hline Chromium & 11 & 8.6 & 8.7 & 7.5 & 11 & 8.8 & 7.4 \\
\hline Copper & 9.5 & 10 & 9.5 & 5.4 & 7.0 & 7.2 & 15 \\
\hline Lead & 68 & 41 & 34 & 2.1 & 41 & 1.7 & 22 \\
\hline Antimony & ND & ND & ND & ND & ND & ND & ND \\
\hline Zinc & 158 & $\mathrm{ND}$ & ND & ND & ND & ND & ND \\
\hline \multicolumn{8}{|c|}{ Volatile Organic Compounds ( $\mu \mathrm{g} / \mathrm{kg}$ ) } \\
\hline Acetone & 7.27 & 29.6 & 9.01 & 6.47 & 10.2 & 9.51 & 2.45 \\
\hline Trichloroethylene & $\mathrm{ND}$ & ND & $\mathrm{ND}$ & ND & $\mathrm{ND}$ & ND & ND \\
\hline \multicolumn{8}{|c|}{ Semivolatile Organic Compounds ( $\mu \mathrm{g} / \mathrm{kg}$ ) } \\
\hline Butylbenzl phthalate & ND & ND & 528 & ND & ND & ND & 3,700 \\
\hline Benzoic acid & 3,400 & 12,000 & ND & 1,800 & 949 & 654 & 3,700 \\
\hline
\end{tabular}

also detected in the unfiltered sample from location 7 (51.9, 7,000, and $20 \mu \mathrm{g} / \mathrm{L}$, respectively). As described in Section 2.3.1.2, the USGS and the EPA ERT sampled surface water and sediment from areas offshore of the RCP.

In general, the nearshore surface water quality data from the samples collected to date show essentially no contamination. What contamination there is appears to be associated with the suspended solids. This finding suggests that the nearshore sediments may be contaminated.

\section{Groundwater}

Two monitoring wells (TH9 and TH10 in Figure 2.13) were installed near the RCP area as part of the 1977 environmental contamination survey (Nemeth 1989). The depth of the wells ranged from 20 to $25 \mathrm{ft}$. The wells were screened in the surficial aquifer (Sonntag 1991). Water samples collected from the wells in 1977 were analyzed for metals, indicator chemicals, WP, mustard degradation products, cholinesterase inhibitors, BNAs, and VOCs. Only very low levels of organic contamination were detected. Because of the erosion of the shoreline west of the RCP, well TH9 was abandoned, and the shoreline was stabilized with gabion baskets and riprap. 


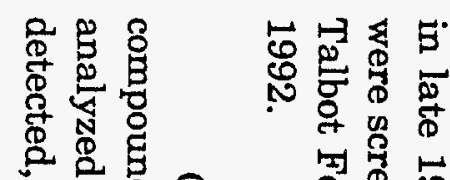

氮的

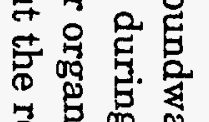

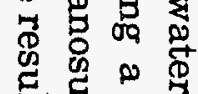

究要

安员

胥

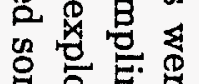

范

\& 8

㝵离范

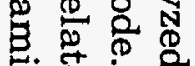

吕

范

प्ष 要

它电

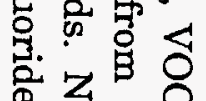

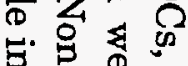

ర大

吉鸟点

造

○葛员

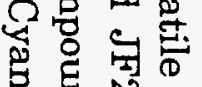

范

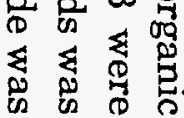

武客

3.

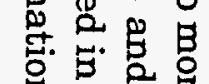

它

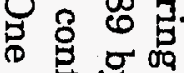

马 G

总客苛

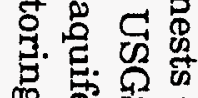

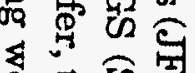

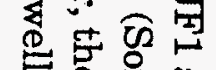

¿

鸟要出

氙

\&

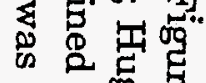

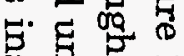

密界 N

菏

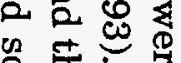

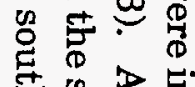

点蛋蛋

옹

居通

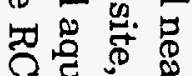

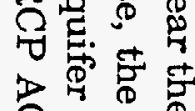

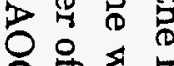

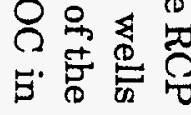

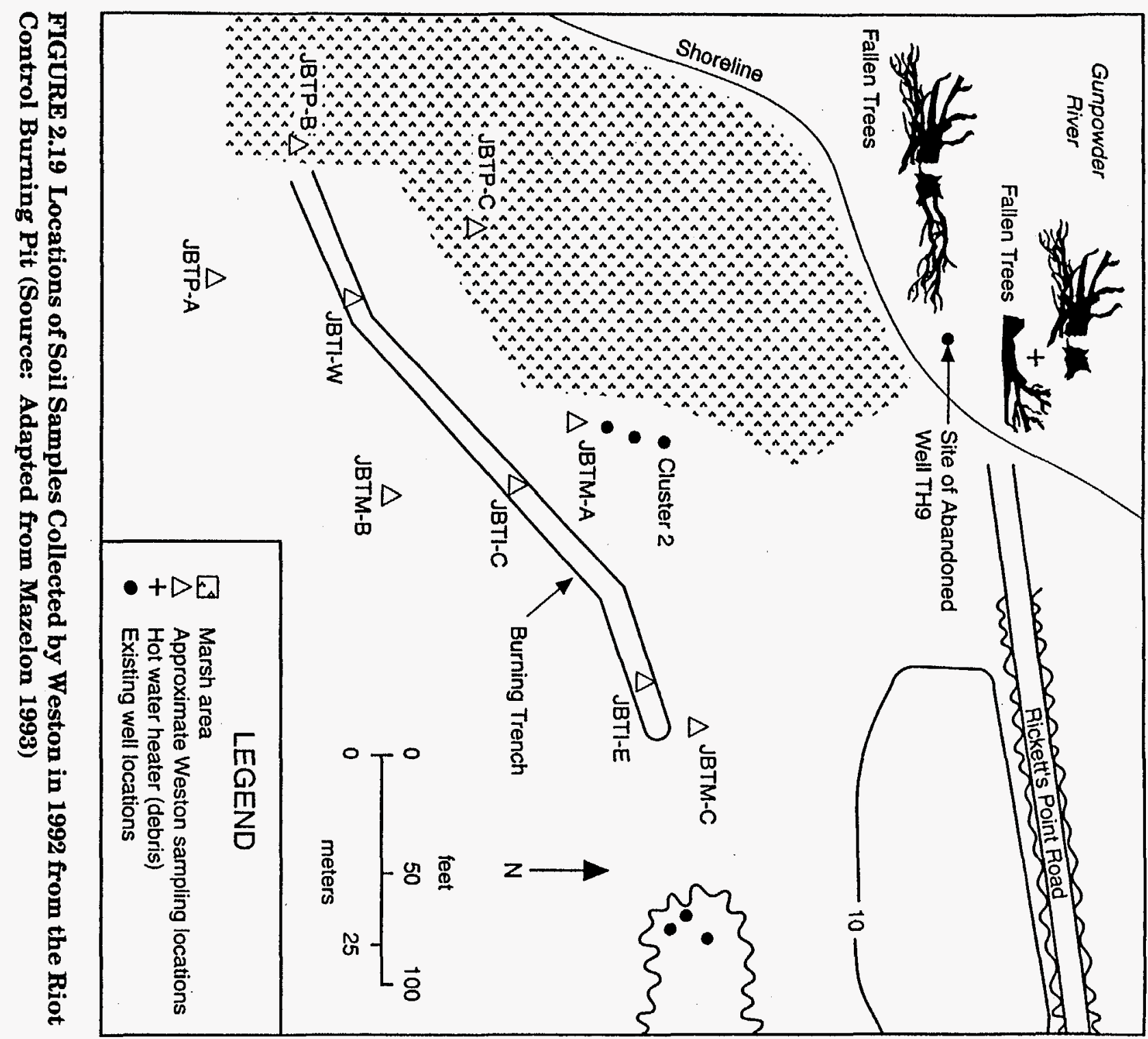

ஸ் 
TABLE 2.19 Analytical Results for TCL Analytes in Selected Soil Samples from the Riot Control Burning Pit Area, 1992

\begin{tabular}{|c|c|c|c|c|c|c|}
\hline \multirow[b]{2}{*}{ TCL Analyte } & \multicolumn{6}{|c|}{ Concentrations ( $\mathrm{gg} / \mathrm{kg}$ ) by Soil Sample Location } \\
\hline & $\mathrm{JBT} 1-\mathrm{E}\left(3^{\prime \prime}\right)^{\mathrm{b}}$ & $\mathrm{JB} \mathrm{B}^{\prime} 1-\mathrm{E}\left(\mathbf{2}^{\prime}\right)$ & JBT1-E(4) & JBP1-W(3") & JBT1-W(2) & JBT1-W(4') \\
\hline \multicolumn{7}{|l|}{ Volatile Organic Compounds } \\
\hline Acetone & 61.8 & 46.2 & 191 & 236 & 82.2 & 18.5 \\
\hline Benzene & $\mathrm{ND}^{\mathrm{c}}$ & ND & ND & ND & ND & ND \\
\hline Carbon disulfide & ND & ND & ND & ND & ND & ND \\
\hline Chloroform & $\mathrm{ND}$ & ND & ND & ND & ND & ND \\
\hline Chloroethane & ND & ND & ND & ND & ND & ND \\
\hline Chloromethane & 10.3 & 7.7 & 5.22 & 13.2 & 17.6 & 6.75 \\
\hline Styrene & ND & ND & ND & ND & ND & ND \\
\hline Toluene & $\mathrm{ND}$ & ND & ND & ND & ND & ND \\
\hline Xylenes & ND & ND & ND & ND & ND & ND \\
\hline \multicolumn{7}{|c|}{ Semivolatile Organic Compounds } \\
\hline 2-Methylnaphthalene & 52 & ND & ND & ND & ND & $\mathrm{ND}$ \\
\hline Benzoic acid & ND & ND & ND & 183 & 79.2 & 47.8 \\
\hline bis-(2-Chloromethyl) ether & ND & ND & ND & ND & ND & $\mathrm{ND}$ \\
\hline bis-(2-Ethylhexyl) phthalate & ND & ND & ND & ND & ND & ND \\
\hline Di-n-butyl phthalate & ND & ND & ND & 217 & 111 & 54.1 \\
\hline Fluoranthene & ND & ND & ND & ND & ND & ND \\
\hline Hexachlobenzene & ND & ND & ND & ND & ND & ND \\
\hline Pyrene & ND & ND & ND & ND & ND & ND \\
\hline \multicolumn{7}{|l|}{ Pesticides } \\
\hline $4,4^{\circ}$ DDD & ND & ND & ND & ND & ND & ND \\
\hline $4,4^{\prime} \mathrm{DDE}$ & 2.22 & ND & ND & 10.6 & ND & ND \\
\hline $4,4^{\circ} \mathrm{DDT}$ & ND & ND & $\mathrm{ND}$ & ND & ND & ND \\
\hline \multicolumn{7}{|l|}{$P C B s$} \\
\hline Aroclor 1248 & ND & ND & ND & ND & ND & ND \\
\hline Aroclor 1254 & ND & ND & ND & ND & ND & ND \\
\hline
\end{tabular}


TABLE 2.19 (Cont.)

Concentrations $(\mu \mathrm{g} / \mathrm{kg})$ by Soil Sample Location

\begin{tabular}{|c|c|c|c|c|c|c|c|c|}
\hline \multirow[b]{2}{*}{ TCL Analyte } & \\
\hline & JBTM-A $\left(3^{\prime \prime}\right)$ & JBTM-A(1') & JBTM-C(3") & JBTM-C(1') & JBTP-A(3") & JBTP-A(1') & JBTP-C(3") & JBTP-C(1) \\
\hline \multicolumn{9}{|l|}{ Volatile Organic Compounds } \\
\hline Acetone & 171 & 55.4 & 169 & 91 & 70.4 & 74.3 & ND & ND \\
\hline Benzene & ND & ND & ND & 2.46 & ND & ND & ND & ND \\
\hline Carbon disulfide & ND & ND & ND & ND & 4.89 & ND & ND & ND \\
\hline Chloroform & ND & ND & ND & $\mathrm{ND}$ & ND & ND & 20.3 & ND \\
\hline Chloroethane & 12.2 & 2.72 & ND & ND & $\mathrm{ND}$ & ND & ND & $\mathrm{ND}$ \\
\hline Chloromethane & 10.2 & 5.75 & 5.87 & 9.75 & 12.2 & 5.69 & 5.69 & 3.26 \\
\hline Styrene & 8.57 & $\mathrm{ND}$ & ND & $\mathrm{ND}$ & ND & 18 & ND & ND \\
\hline Toluene & 42.3 & 16.2 & 7.9 & 1.77 & ND & 1.44 & ND & ND \\
\hline Xylenes & 159 & 77.2 & ND & ND & ND & ND & ND & ND \\
\hline \multicolumn{9}{|c|}{ Semivolatile Organic Compounds } \\
\hline 2-Methylnaphthalene & ND & ND & ND & ND & ND & ND & $\mathrm{ND}$ & ND \\
\hline Benzoic acid & 4,380 & 100 & ND & 63.6 & 840 & 336 & ND & 106 \\
\hline bis-(2-Chloromethyl) ether & 438 & ND & ND & ND & 64.5 & ND & 54 & ND \\
\hline bis-(2-Ethylhexyl) phthalate & ND & ND & ND & ND & ND & 41.5 & ND & ND \\
\hline Di-n-butyl phthalate & 126 & 53.5 & ND & ND & ND & $\mathrm{ND}$ & ND & 188 \\
\hline Fluoranthene & ND & ND & ND & ND & ND & ND & ND & ND \\
\hline Hexachlobenzene & ND & ND & ND & ND & ND & ND & ND & ND \\
\hline Pyrene & ND & ND & ND & ND & ND & ND & ND & ND \\
\hline \multicolumn{9}{|l|}{ Pesticides } \\
\hline 4,4` DDD & ND & ND & ND & $\mathrm{ND}$ & ND & ND & ND & ND \\
\hline $4,4^{\prime} \mathrm{DDE}$ & 32.9 & ND & ND & 1.79 & 10.1 & ND & 4.69 & ND \\
\hline $4,4^{\prime} \mathrm{DDT}$ & 8.28 & ND & ND & ND & $\mathrm{ND}$ & ND & ND & ND \\
\hline \multicolumn{9}{|l|}{ PCBs } \\
\hline Aroclor 1248 & ND & ND & ND & ND & ND & ND & ND & ND \\
\hline Aroclor 1254 & ND & ND & ND & ND & ND & ND & ND & ND \\
\hline
\end{tabular}

a Only detected analytes are reported; for samples with duplicate analyses, the higher value is reported.

b Sample depth shown in parentheses.

c $\mathrm{ND}=$ not detected. 
TABLE 2.20 Analytical Results for TAL Analytes in Selected Soil Samples from the Riot Control Burning Pit Area, 1992 ${ }^{\text {a }}$

\begin{tabular}{|c|c|c|c|c|c|c|c|}
\hline \multirow{2}{*}{$\begin{array}{c}\text { TAL } \\
\text { Analyte }\end{array}$} & \multicolumn{7}{|c|}{ Concentration (mg/kg) by Soil Sample Location } \\
\hline & JBT1-E(3") & JBT1-E(2) & JBT1-E(4') & JBT1-W(3") & JBT1-W(2) & JBT1-W(4') & JBTM-A(3") \\
\hline Antimony & $\mathrm{ND}^{\mathrm{c}}$ & 5.31 & ND & ND & ND & ND & $\mathrm{ND}$ \\
\hline Arsenic & 4.96 & 4.27 & ND & ND & 2.94 & 1.84 & 2.77 \\
\hline Beryllium & 0.374 & 0.343 & ND & 0.355 & 0.362 & 0.278 & 0.555 \\
\hline Cadmium & 5.24 & 2.73 & ND & 0.907 & 0.690 & ND & 0.994 \\
\hline Chromium & 106 & 40 & 11.9 & 11.3 & 17.3 & 16.6 & 14.2 \\
\hline Cobalt & ND & ND & ND & ND & $\mathrm{ND}$ & ND & ND \\
\hline Copper & 742 & 262 & 116 & 23.2 & ND & 9.79 & 12.3 \\
\hline Lead & 1.14 & 49.2 & 10.9 & 60.5 & 8.98 & 8.92 & 57.1 \\
\hline Zinc & 281 & 139 & .45 .6 & 119 & 17.2 & 14.6 & 46.6 \\
\hline Nickel & 40.2 & 23.2 & 9.89 & ND & 9.08 & 8.01 & 12.6 \\
\hline
\end{tabular}

Concentration $(\mathrm{mg} / \mathrm{kg})$ by Soil Sample Location

\begin{tabular}{|c|c|c|c|c|c|c|c|}
\hline Analyte & JBTM-A(1') & JBTM-C(3") & JBTM-C(1) & JBTP-A(3") & JBTP-A(1') & JBTP-C(3") & JBTP-C(1') \\
\hline Antimony & $N^{c}$ & ND & ND & ND & ND & ND & ND \\
\hline Arsenic & ND & 1.87 & 1.72 & ND & 2.18 & 2.28 & 1.81 \\
\hline Beryllium & 0.337 & 0.451 & 0.279 & 0.418 & 0.328 & ND & 0.745 \\
\hline Cadmium & 0.586 & 0.898 & 0.696 & 1.7 & 0.601 & ND & ND \\
\hline Chromium & 8.06 & 12.1 & 11.1 & 12.6 & 14.2 & 14.1 & 24.3 \\
\hline Cobalt & ND & ND & ND & ND & ND & ND & ND \\
\hline Copper & ND & 9.01 & ND & 8.98 & ND & 11.3 & 9.41 \\
\hline Lead & 5.97 & 52.2 & 7.61 & 33.2 & 7.23 & 41.8 & 9.13 \\
\hline Zinc & 5.02 & 58.9 & 6.77 & 22.2 & 11.3 & 39.4 & 36.3 \\
\hline Nickel & ND & 8.27 & 7.16 & 17.5 & ND & ND & 11.2 \\
\hline
\end{tabular}

a Only detected analytes are reported; for samples with duplicate analyses, the higher value is reported.

b Sample depth shown in parentheses.

c $\mathrm{ND}=$ not detected. 
found in well JF22 at a concentration of $65.6 \mu \mathrm{g} / \mathrm{L}$. The VOC measurements for well JF13 showed the presence of benzene $(1,500 \mu \mathrm{g} / \mathrm{L})$ and methylisobutylketone $(640 \mu \mathrm{g} / \mathrm{L})$. Benzene was also detected at $800 \mu \mathrm{g} / \mathrm{L}$ in well JF13 during a 1992 sampling episode. No volatile organic compounds were detected in the newly installed well (143) (USGS 1992).

\subsubsection{Potential Pathways of Contaminant Migration}

Existing data indicate that the main pathway of contaminant migration at the RCP $A O C$ is movement through the vadose zone down into the groundwater and then transport by groundwater.

The direction of groundwater movement in the Talbot aquifers appears to be away from the RCP AOC toward the Gunpowder River and Chesapeake Bay. However, the lateral gradients in the lower aquifers are quite small (USGS 1991). Vertical movement of groundwater appears to be down through the aquifers. Offshore, there may be upward flow from each of the three Talbot aquifers into the Gunpowder and Bush rivers. Movement in the surface and confined aquifers is affected by the tides (USGS 1991).

Surface water and associated sediment transport may play some role in contaminant migration in that surface runoff, particularly after intense storms, may carry dissolved and suspended contaminants from the contaminated areas into the river and bay. Lateral contaminant migration by surface water is expected to be minor (Sonntag 1991). However, surface water percolating through and leaching contaminated soils may be a major pathway by which contaminants, especially metals and VOCs, move down into the groundwater. Any contaminants that may have been present in the past in sufficient amounts to exist as free liquid in the soil would be expected to migrate down, independent of the presence of water.

Because of the generally humid conditions in the J-Field study area, wind transport of contaminated soil in areas with a good vegetative cover is expected to be minor. Diffusion of contaminated soil gas into the atmosphere and direct volatilization of contaminants from the soil are also expected to be release mechanisms.

\subsubsection{South Beach Trench}

\subsubsection{Types of Waste Present}

No information is available concerning chemical or hazardous material disposal in the SBT. It is possible that the trench was originally used as a borrow pit to obtain soil for the demolition work on the South Beach of J-Field (Nemeth 1989). A review of aerial photographs reveals the presence of an additional trench, which is now filled in but visible, about $40 \mathrm{ft}$ west of current SBT. In the photographs, the western trench is oriented east-west and is about $300 \mathrm{ft}$ in length. Small drums are scattered in the woods near the western trench (U.S. Army 1965). 


\subsubsection{Types of Contaminants Present}

\section{Soil Gas}

Soil-gas samples have not been collected from this area.

\section{Soil}

Analysis of a single soil sample collected in the SBT area as part of an environmental survey in 1983 (Nemeth 1989) showed a low level of chlordane (53 $\mu \mathrm{g} / \mathrm{kg}$ ) and tentatively identified several other organic compounds. Two soil samples were collected by the USGS in the SBT area (locations 21 and 22 in Figure 2.9). The samples were collected at 1-ft depths and analyzed for indicator parameters, metals, VOCs, semivolatile compounds, and explosives-related compounds (Hughes 1992). The results indicate that metals are present in low concentrations: lead, ranging from 2 to $22 \mathrm{mg} / \mathrm{kg}$; copper, from 7 to $15 \mathrm{mg} / \mathrm{kg}$; and chromium, from 7 to $9 \mathrm{mg} / \mathrm{kg}$. Acetone was the only organic compound detected (ranging from 10 to $25 \mathrm{mg} / \mathrm{kg}$ ).

\section{Surface Water}

Surface water samples have not been collected at the SBT.

\section{Groundwater}

A monitoring well (TH10 in Figure 2.13) was installed south of the trench during the 1977 environmental survey (Nemeth 1989). Water collected from this well was analyzed for extractable organic compounds; analyses showed the presence of hydrocarbons, dimethylnaphthalene, and N,N-dimethylformamide. This well was also sampled as part of the RFA, with analysis for VOCs, BNAs, pesticides, and PCBs. No contaminants were detected in the water at that time (Nemeth 1989).

The USGS sampled well TH10 in 1991 as part of the hydrological assessment, Phase I. The water was analyzed for metals, water quality parameters, major ions, VOCs, and explosives-related compounds. No contamination was detected. Samples collected in 1992 from wells JF1 and JF2 were analyzed for VOCs. Benzene concentrations ranged from 110 to $800 \mu \mathrm{g} / \mathrm{L}$ in the surficial aquifer. Low levels of acetone were also detected.

\subsubsection{Potential Pathways of Contaminant Migration}

The main pathway of contaminant migration at the South Beach Trench is believed to be movement through the vadose zone into the groundwater and then transport by the groundwater. 
The direction of groundwater movement in the Talbot aquifers appears to be away from the trench area toward the bay. However, the lateral gradients in the lower aquifers are quite small (USGS 1991). The vertical movement of groundwater appears to be down through the aquifers; however, offshore there may be upward flow from each of the three Talbot aquifers into the Gunpowder and Bush rivers. Movement in the surficial and confined aquifers is affected by the tides (USGS 1991).

Surface water and associated sediment transport may play some role in contaminant migration in that surface runoff, particularly after intense storms, may carry dissolved and suspended contaminants from contaminated soil down into the bay. Lateral contaminant migration by surface water is expected to be minor (Sonntag 1991). However, surface water percolating through and leaching contaminated soils may be a major pathway by which contaminants, especially metals and VOCs, move down into the groundwater. Any contaminants that may have been present in the past in sufficient amounts to exist as free liquid in the soil would be expected to migrate down independent of the presence of water.

Because of the generally humid conditions and the presence of a vegetative cover over the South Beach Trench, wind transport of contaminated soil is expected to be minor. Diffusion of contaminated soil gas into the atmosphere and direct volatilization of contaminants from the soil are also expected to be minor.

\subsubsection{South Beach Demolition Ground}

\subsubsection{Types of Waste Present}

The SBDG was used as a demolition site for HE during the 1960s and 1970s. Items were detonated either at the ground surface or buried several feet deep. Because of the high rates of erosion at J-Field, the SBDG is now offshore in the Chesapeake Bay (Hughes 1993). Its presence is marked only by the abundant fragments of munitions and pieces of metal that can be observed at low tide.

\subsubsection{Types of Contaminants Present}

\section{Soil Gas and Soil}

Soil-gas and soil sampling and analysis were not conducted because the area is now offshore.

\section{Surface Water}

Surface water samples were collected by the USGS in 1991 at low tide close to the SBDG shore (locations 12 and 13 in Figure 2.11). Both filtered and unfiltered samples were 
analyzed for major water quality parameters, metals, and a few organic compounds. Phenol, TOC, and TOX were detected in the unfiltered sample from location $13(9.6,4,000$, and $30.4 \mu \mathrm{g} / \mathrm{L}$, respectively).

As described in Section 2.3.1.2, the USGS and EPA ERT sampled surface water and sediment from the location of the SBDG. In general, the nearshore surface water data from the samples collected to date show essentially no contamination. What contamination that does exist appears to be associated with the suspended solids. This suggests that the nearshore sediments may be contaminated. Additional data are needed to evaluate the nearshore sediments.

\section{Groundwater}

Groundwater sampling and analysis were not performed because the area is now offshore and no wells are present in the immediate area.

\subsubsection{Potential Pathways of Contaminant Migration}

The main pathway of contaminant migration at the SBDG is expected to be by surface water, including wave action and tidal action. This conclusion is valid only for metals, because organic compounds most likely would have degraded in the bay. Because this area is currently under water, wind transport of contaminants is expected to be an insignificant migration pathway.

\subsubsection{Prototype Building}

\subsubsection{Types of Waste Present}

The PB area was believed to be used primarily for the storage of solid waste when disposal operations were active at J-Field. In addition, a review of aerial photographs suggests that there was a burning area about $200 \mathrm{ft}$ west of the PB and near the edge of the existing tree line. The southern boundary of the area is marked by piles of soil, while its northern edge is marked by tall reeds and shallow ponded water. A rusted drum and scrap metal have been found on the ground surface (U.S. Army 1965). Another suspect burning area is located northeast of the PB. No records were kept of the types or quantities of material stored or potentially burned at the PB. 


\subsubsection{Types of Contaminants Present}

\section{Soil Gas}

Soil-gas sampling and analysis were not performed in this area.

\section{Soil}

As part of the 1986 RFA (Nemeth 1989), surface soil samples collected at several locations near the PB (Figure 2.8) were analyzed for metals, extractable metals, and explosives-related compounds. Composites of samples from different locations were analyzed for BNAs, pesticides, and PCBs.

Cadmium and lead were detected at concentrations of 16.6 and $1,622 \mathrm{mg} / \mathrm{kg}$ (respectively) near the southern side of the PB. Organic compounds were also present in the soil samples, but below measurable levels. A composite sample taken near the PB contained low concentrations of pesticides, including $1.0 \mathrm{mg} / \mathrm{kg}$ each of DDD, DDE, and DDT.

Soil samples were collected by the USGS in 1991 at 36 sites in J-Field, including the PB (locations 11 through 15 in Figure 2.9). The samples were collected at 1-ft depths and analyzed for indicator parameters, metals, VOCs, semivolatile compounds, and explosivesrelated compounds (Hughes 1992). The analyses showed that metals contamination is present at the site, especially at location 15, where lead was detected at $93.3 \mathrm{mg} / \mathrm{kg}$, chromium at $18.8 \mathrm{~m} / \mathrm{kg}$, copper at $47.5 \mathrm{mg} / \mathrm{kg}$, and zinc at $158 \mathrm{mg} / \mathrm{kg}$. Limited analyses for organic compounds were also conducted; no significant contamination was found.

\section{Surface Water}

As noted in Section 2.3.1.2, the USGS and EPA ERT sampled surface water and sediment offshore from the PB.

\section{Groundwater}

Three monitoring wells were installed in the area of the PB (wells TH5, TH6, and TH8 in Figure 2.13). Analysis of a water sample collected from TH5 during an environmental survey (Nemeth 1989) showed only compounds related to well construction. Minor amounts of hydrocarbons were detected in groundwater from TH8. The compounds 111TCE and dimethyl disulfide were detected in well TH6 (on the southern side of the PB).

An additional monitoring well nest, JF3, was installed near the PB by the USGS (Sonntag 1991; Hughes 1993). The well nest consists of three wells, screened in the confined aquifer, the leaky confined unit, and the surficial aquifer of the Talbot Formation (Figure 2.13). Groundwater samples were analyzed for metals, water quality parameters, 
VOCs, and semivolatile organic compounds. The results of VOC measurements on samples from well TH8 showed that benzene $(6.43 \mu \mathrm{g} / \mathrm{L})$ and methylisobutylketone $(120 \mu \mathrm{g} / \mathrm{L})$ contamination is present. However, no VOCs were detected in well TH8 or in wells JF3-1, JF3-2, and JF3-3 during a 1992 sampling episode (USGS 1992).

\subsubsection{Potential Pathways of Contaminant Migration}

The main pathway of contaminant migration at the PB is believed to be movement through the vadose zone into the groundwater and then transport by the groundwater.

The direction of groundwater movement in the Talbot aquifers appears to be away from the PB toward the Gunpowder River. However, the lateral gradients in the lower aquifers are quite small (USGS 1991). The vertical movement of groundwater appears to be down through the aquifers; however, offshore there may be upward flow from each of the three Talbot aquifers and into the Gunpowder and Bush rivers. Movement in the surface and confined aquifers is affected by the tides (USGS 1991).

Surface water and associated sediment transport may play some role in contaminant migration in that surface runoff, particularly after intense storms, may also carry dissolved and suspended contaminants from the soil toward the river. Lateral contaminant migration by surface water is expected to be minor (Sonntag 1991). However, surface water percolating through and leaching contaminated soils may be a major pathway by which contaminants, especially metals and VOCs, move down into the groundwater. Any contaminants that may have been present in the past in sufficient amounts to exist as free liquid in the soil would be expected to migrate down, independent of the presence of water.

Because of the generally humid conditions in the J-Field study area, wind transport of contaminated soil in areas with a good vegetative cover is expected to be a minor migration pathway. Diffusion of contaminated soil gas into the atmosphere and direct volatilization of contaminants from the soil are also expected to be minor. However, because portions of the PB area are unvegetated or are sparsely covered with stressed vegetation, and because at least part of the area is expected to be used for open burning, the air pathway may be significant.

\subsubsection{Robins Point Tower Site}

\subsubsection{Types of Waste Present}

Robins Point was a launch and observation site for rocket testing programs conducted in the J-Field area. No information has been uncovered to indicate that solid or hazardous waste was generated or handled at this site. However, Nemeth (1989) found records indicating that radioactive contaminated wood may have been burned at this site. 


\subsubsection{Types of Contaminants Present}

\section{Soil Gas}

Soil-gas sampling and analysis were not conducted in this area.

\section{Soil}

Field inspection of this site found no visual evidence of soil contamination. Because no information exists that waste was ever handled in this area, soil sampling and analysis were not conducted. No radiation above normal background levels was detected in a field radiation survey conducted during February 1988 (Nemeth 1989).

\section{Surface Water}

As noted in Section 2.3.1.2, the USGS and the EPA ERT sampled surface water and sediment offshore from the RPTS.

\section{Groundwater .}

Groundwater samples from monitoring well TH11 (Figure 2.13) were analyzed for extractable organic compounds. Results indicated very low levels of triethylchlorobenzene and TCLEE. As part of the 1986 RFA, the well was resampled for VOCs, BNAs, pesticides, and PCBs. No contaminants were detected.

An additional monitoring well (JF1) was installed near the tower by the USGS as part of their hydrological assessment (Sonntag 1991; Hughes 1993). The well is screened in the Potomac Group (Figure 2.13). Groundwater samples were analyzed for metals, water quality parameters, VOCs, and semivolatile organic compounds. Data for well JF1 showed low levels of VOC contamination $(2.25 \mu \mathrm{g} / \mathrm{L} 111 \mathrm{TCE}$ at a depth of 185-190 ft). However, this finding must be taken as provisional, because one of the two quality control water blanks also showed contamination with TCLEA, TCLEE, and TRCLE (USGS 1992). For the sake of comparison, an upgradient well (JF2) of similar depth, located at the J-Field gate entrance also had detectable concentrations of TRCLE during the same sampling episode. Acetone and 1,1-dichloroethane were detected at concentration of 4 and $1 \mu \mathrm{g} / \mathrm{L}$, respectively in a 1992 sampling event (USGS 1992).

\subsubsection{Potential Pathways of Contaminant Migration}

No information is available to verify that solid or hazardous waste was generated or handled at this site. A test burn of radioactive contaminated wood may have occurred at the 
site; however, the limited sampling conducted to date indicates that this area is not a source of contamination. Thus there are no potential pathways for contaminant migration.

\subsubsection{Robins Point Demolition Ground}

\subsubsection{Types of Waste Present}

The inactive portion of the RPDG was used primarily for demolition of explosive materials. Small amounts of sensitive and unstable chemicals were occasionally destroyed at the area. A portion of the RPDG is still used for emergency disposal operations.

\subsubsection{Types of Contaminants Present}

\section{Soil Gas}

Soil-gas sampling and analysis were not conducted in this area.

\section{Soil}

Surface soil collected during the 1986 RFA was analyzed for metals, explosivesrelated compounds, and organic compounds. The analyses did not detect any contamination in the RPDG (Nemeth 1989).

Soil samples were collected by the USGS at 36 sites at J-Field, including the RPDG (locations 37 through 41 in Figure 2.9). The samples, collected at 1-ft depths, were analyzed for indicator parameters, metals, VOCs, semivolatile organic compounds, and explosives (Hughes 1992). The results indicated the presence of metals in low concentrations, including lead, up to $20.3 \mathrm{mg} / \mathrm{kg}$ at location 38 ; chromium, up to $16.3 \mathrm{mg} / \mathrm{kg}$ at location 37 ; copper, up to $75.5 \mathrm{mg} / \mathrm{kg}$ at location 37 ; and zinc, up to $22.8 \mathrm{mg} / \mathrm{kg}$ at location 39 . Limited analyses for organic compounds were also conducted; no significant contamination was found.

\section{Surface Water}

Laboratory analyses of standing water conducted during the 1986 RFA did not detect any contamination by metals, explosives, or organic compounds (Nemeth 1989).

\section{Groundwater}

Two monitoring wells were installed in the active portion of the RPDG in 1992 and will be sampled as a part of the RI. However, groundwater contamination is not expected 
given the short period of time the site was used, the nature of the operations, and the absence of soil and surface water contamination.

\subsubsection{Potential Pathways of Contaminant Migration}

Given the nature of the operations at the site and the absence of soil and surface water contamination, it is doubtful that any contamination still exists at this site. However, surface water that ponds west of a berm separating the active from the inactive portion of the RPDG seeps through the berm and discharges into the inactive portion of the site. As a result, surface water may play some role in contaminant migration in that surface runoff may carry dissolved and suspended contaminants from the active portion of the site into the inactive portion.

\subsection{OTHER RELEVANT SITE ASPECTS}

\subsubsection{Preliminary Identification of ARARs and TBC Information}

Section 121 of CERCLA requires that remediation actions must attain standards, requirements criteria, or limitations that are "legally applicable or relevant and appropriate" requirements (ARARs) under the site-specific scenario for any hazardous substance that will remain on-site after remediation. Section 121 of CERCLA further specifies that state standards can be considered as potential ARARs when they are promulgated standards that are more stringent than federal standards, providing the state standards have been identified by the state in a timely matter during the RI/FS process.

The distinction between "applicable" and "relevant and appropriate" requirements is made clear in the revised National Contingency Plan (NCP) contained in 40 CFR Part 300. In general, the term "applicable requirements" pertains to substantive requirements that relate specifically to a hazardous substance, remedial action, location, or other "circumstance" found at a CERCLA site. Such substantive requirements could include cleanup standards, criteria, or limits promulgated under state or federal statutes. "Relevant and appropriate requirements" are substantive requirements that may not be directly applicable to a specific CERCLA site scenario but are deemed to address problems or situations sufficiently similar to such a scenario encountered at the CERCLA site that their use is well suited to the particular site.

Potential requirements for a proposed CERCLA remedial action can also be referred to as "to be considereds" (TBCs). The TBC category consists of standards or guidelines that have been published but not promulgated and that may have significance for all or part of the action. Potential TBC requirements are typically considered only if no promulgated requirements exist that are either applicable or relevant and appropriate.

Although it may be premature to establish specific ARARs and TBCs for J-Field because additional information must be gathered about the site, the early identification of 
ARARs and TBCs can aid the planning process by allowing investigators to make decisions regarding which remedial alternatives will likely be sufficiently protective and cost effective. The lists of preliminary and potential ARARs presented in Tables A.1 through A.4 constitute sets of requirements that can be expanded, reduced, and/or refined as additional information is gathered about the site. The ARARs presented in these tables have been separated into (1) Maryland state regulations and TBCs and (2) federal regulations and TBCs for J-Field. The federal ARARs have been further subdivided into contaminant-specific, location-specific, and action-specific ARARs.

\subsubsection{Contaminant-Specific ARARs}

Contaminant-specific ARARS are methodologies, or health- or risk-based numerical thresholds, that can be applied to site-specific conditions at a CERCLA site to establish standards. Contaminant-specific ARARs establish the allowable amount or concentration of a hazardous substance that may exist or be released to the ambient environment. The list of chemical constituents included in the tables in Appendix A is somewhat speculative because the investigative effort may not have identified all constituents present at the site.

Chemical warfare agents and the residue from their treatment are considered acutelisted hazardous wastes under Maryland hazardous waste management regulations and are listed as Class I Toxic Air Pollutants under Maryland regulations. As such, these regulations are included in Appendix A as potential ARARs. However, there are no CWA treatment standards for land disposal or specific numerical limits on CWA in media.

Because whatever standards or criteria the U.S. Army may have developed to regulate $\mathrm{OB} / \mathrm{OD}$ activities have not been promulgated, such standards or criteria have not been included in Appendix A. However, ANL will rely on CWA-related standards or criteria developed by the U.S. Army, the host installation, and associated tenant activities throughout the investigation and remediation of the site. Such CWA-related standards or criteria will be evaluated for inclusion as TBC information.

\subsubsection{Location-Specific ARARs}

Location-specific ARARs relate to limitations placed on the concentrations of hazardous substance or performance standards established for particular locations. Relevant locations could include threatened or endangered species habitats or other sensitive ecosystems or habitats, wetlands, floodplains, or historic or archaeological sites.

\subsubsection{Action-Specific ARARs}

Action-specific ARARs are technology- or performance-based standards that relate to actions associated with remediation of the site. 


\subsubsection{Preliminary Remediation Goals}

Preliminary remediation goals (PRGs) can be developed for the operable units at $\mathrm{J}$-Field on the basis of the existing information. These goals, which are in essence preliminary cleanup levels, require information on the environmental media of concern, the chemicals of concern, and the probable land use for each operable unit at J-Field (EPA 1991a).

\subsubsection{Environmental Media of Concern and Potential Concern}

It is useful to distinguish environmental media that are of concern and of potential concern. A medium is of concern if existing analytical data are sufficient to show that the medium is contaminated. A medium is of potential concern if the existing sampling data for the medium are insufficient to show contamination, but sampling data for other media or the site history indicate a potential for contamination. The status of the environmental media for the eight J-Field sites is summarized in Table 2.21. Details are provided in the following subsections.

\section{Toxic Burning Pits}

Existing analytical data indicate that soil and groundwater are environmental media of concern at the TBP AOC. Surface water and sediments in the adjacent marshes are media of potential concern. No existing analytical data show that these media are contaminated, but the possibility of surface runoff into the marshes to the east and south, pushout of burned soil and debris into the marshes, and general J-Field history indicate a potential for concern. The elevated soil-gas contamination in the area and the possible existence of contaminated fugitive dust indicate that the atmosphere may also be a medium of potential concern (ANL 1993, 1994).

\section{White Phosphorus Burning Pits}

Soil and groundwater are also media of concern at the WPP AOC. In addition, offshore sediments are of potential concern. This conclusion is based on the shore erosion occurring in the area (Weston 1992) and the observed elevated concentrations of metals and TOX in unfiltered water samples only (USGS 1991). Any surface water in the area is also a medium of potential concern. However, there are no marshes nearby, so marsh sediments and water are not media of potential concern. The atmosphere is a medium of potential concern because of the possibility of contaminated windborne fugitive dust originating at the site, elevated soil-gas contamination, and the reported odor of the chemical agent $\mathrm{CN}$ in the area (Nemeth 1989; Weston 1992). 
TABLE 2.21 Environmental Media of Concern or Potential Concern at the J-Field Sites

\begin{tabular}{|c|c|c|c|c|c|c|}
\hline \multirow[b]{2}{*}{ Site } & \multicolumn{6}{|c|}{ Concern $(\mathrm{Y})$ or Potential Concern $(\mathrm{P})^{\mathrm{a}}$} \\
\hline & Soil & $\begin{array}{c}\text { Marsh } \\
\text { Sediment }\end{array}$ & $\begin{array}{l}\text { Offshore } \\
\text { Sediment }\end{array}$ & $\begin{array}{c}\text { Surface } \\
\text { Water }\end{array}$ & $\begin{array}{c}\text { Ground- } \\
\text { water }\end{array}$ & $\begin{array}{l}\text { Atmo- } \\
\text { sphere }\end{array}$ \\
\hline Toxic Burning Pits (TBP) & $\mathrm{Y}$ & $\mathbf{P}$ & - & $\mathbf{P}$ & $\mathrm{Y}$ & $\mathbf{P}$ \\
\hline $\begin{array}{l}\text { White Phosphorus Burning } \\
\text { Pits (WPP) }\end{array}$ & $\mathrm{Y}$ & - & $\mathrm{P}$ & $\mathbf{P}$ & $\mathrm{Y}$ & $\mathrm{P}$ \\
\hline $\begin{array}{l}\text { Riot Control Burning Pit } \\
\text { (RCP) }\end{array}$ & $\mathbf{P}$ & $\mathbf{P}$ & $\mathrm{P}$ & $\mathrm{P}$ & $\mathrm{Y}$ & $\mathbf{P}$ \\
\hline Prototype Building (PB) & $\mathrm{Y}$ & - & - & $\mathbf{P}$ & $\mathbf{P}$ & $\mathrm{P}$ \\
\hline South Beach Trench (SBT) & $\mathbf{P}$ & - & - & - & - & - \\
\hline $\begin{array}{l}\text { South Beach Demolition } \\
\text { Ground (SBDG) }\end{array}$ & - & - & $\mathbf{P}$ & $\mathrm{P}$ & $P$ & - \\
\hline $\begin{array}{l}\text { Robins Point Demolition } \\
\text { Ground (RPDG) }\end{array}$ & $\mathbf{P}$ & $\mathrm{P}$ & - & $\mathrm{P}$ & $\mathrm{P}$ & $\mathrm{P}$ \\
\hline $\begin{array}{l}\text { Robins Point Tower Site } \\
\text { (RPTS) }\end{array}$ & $\mathbf{P}$ & - & - & - & $\mathbf{P}$ & - \\
\hline
\end{tabular}

a A hyphen indicates that the medium is not of concern/potential concern.

\section{Riot Control Burning Pit}

Existing data indicate that groundwater is the only medium of concern at the RCP AOC. Soils, surface water, and sediments, both in the nearby marsh and offshore, are media of potential concern, as is the atmosphere. The potential concern for soils and the atmosphere stems from the elevated soil-gas contamination, possible contaminated fugitive dust, and site history (ANL 1994). The potential concern for sediments is based on the shore erosion in the area (Weston 1992), the potential for surface runoff, and the site history.

\section{Prototype Building}

Soil is the only medium of concern at the PB AOC. Groundwater and any surface water at the site are media of potential concern. The potential concern for groundwater is based on possible leaching of soils at the site and the proximity of the site to areas with contaminated groundwater. The potential concern for the atmosphere is based on the possibility of windborne contaminated dust leaving the PB site. 


\section{South Beach Trench}

No media of concern have been identified at the SBT AOC. The presence of a few munitions fragments in the trench, the lack of any disposal history, and the low level of chlordane $(0.053 \mathrm{ppm})$ in a soil sample taken at the site (Nemeth 1989; Sonntag 1991) indicate that soil is the only medium of potential concern.

\section{South Beach Demolition Ground}

No media of concern have been identified at the SBDG AOC. Groundwater, offshore sediments, and water are media of potential concern. This potential concern is based on the past use of the site for HE munitions disposal in holes and the extensive erosion that has placed the site offshore in Chesapeake Bay covered with sand (Nemeth 1989; Sonntag 1991).

\section{Robins Point Demolition Ground}

No media of concern have been identified at the RPDG AOC. The site history indicates that soils and possibly surface water, sediments, and groundwater in and under the nearby marsh are media of potential concern. (The absence of explosives or metals in the few soil samples collected from the site [Nemeth 1989] is believed to be an insufficient reason to exclude soils and other media as of potential concern.) The atmosphere is also a medium of potential concern because of the possible occurrence of windborne contaminated fugitive dust.

\section{Robins Point Tower Site}

No media of concern have been identified at the RPTS AOC. Soil and groundwater are the only media of potential concern. This categorization is based on the lack of information regarding the use of the site for material disposal. The site was used as an observation and launch site for rocket testing. A test burn of material, mainly wood contaminated with radioactivity, was planned for the site in 1959 but may not have occurred (Nemeth 1989).

\subsubsection{Contaminants of Potential Concern}

At each J-Field site, contaminants of potential concern are those that have been detected in samples at concentrations significantly above background, or that could reasonably be expected (on the basis of site history or use) to be present in significant quantities. Tables 2.22 and 2.23 summarize the contaminants of potential concern identified for the J-Field sites. Each table is divided into two sections. The first section lists contaminants of potential concern based on sampling data for each environmental medium; the second section gives contaminants of potential concern based on site history and use. Entries in the second section are not associated with specific environmental media because 
TABLE 2.22 Preliminary Identification of Contaminants of Potential Concern for the Toxic Burning Pits at J-Field

Based on Analytical Data ${ }^{a}$

\begin{tabular}{|c|c|c|c|}
\hline Soil Gas & Soil & Groundwater & \\
\hline $\begin{array}{l}\text { Trichloroethylene } \\
\text { Tetrachloroethylene } \\
\text { Dichloroethylene } \\
\text { Trichloroethanes } \\
\text { Alkanes } \\
\text { Phthalates } \\
\text { Heavy aromatics }\end{array}$ & $\begin{array}{l}\text { Arsenic } \\
\text { Cadmium } \\
\text { Chromium (?) } \\
\text { Lead } \\
\text { Mercury } \\
\text { Zinc } \\
\text { Trichloroethylene } \\
\text { Petroleum hydrocarbons } \\
\text { PCBs } \\
\text { Heptachlor epoxide } \\
\text { Other VOCs } \\
\text { Other pesticides }\end{array}$ & $\begin{array}{l}\text { Arsenic } \\
\text { Nickel (?) } \\
\text { Lead } \\
\text { Selenium } \\
\text { Zinc } \\
\text { Nitrate } \\
\text { Cyanide } \\
\text { Sulfate } \\
\text { PETN } \\
\text { Nitrocellulose } \\
\text { RDX } \\
\text { Nitrobenzene } \\
\text { Cesium-137 } \\
\text { Strontium-90 } \\
\text { Benzene } \\
\text { Chlorobenzene }\end{array}$ & $\begin{array}{l}\text { Ethyl benzene } \\
\text { Toluene } \\
\text { Chloroform } \\
\text { Carbon tetrachloride } \\
\text { 1,1,2-Trichloroethane } \\
\text { 1,1,2,2,-Tetrachloroethane } \\
\text { Vinyl chloride } \\
\text { 1,1-Dichloroethylene } \\
\text { trans-1,2-Dichloroethylene } \\
\text { Trichloroethylene } \\
\text { Tetrachloroethylene } \\
\text { Sulfone } \\
\text { 1,4-Dithiane } \\
\text { 1,4-Oxithiane } \\
\text { Thiodiglycol }\end{array}$ \\
\hline
\end{tabular}

Based on Site History

\begin{tabular}{ll} 
CWAs & Degradation products of CWAs \\
VX & HE munitions \\
Mustard & Explosives-related compounds \\
G-agents & Chlorinated solvents \\
Incapacitating agents (CS, CN) & Smoke munitions (FS, FM) \\
\hline
\end{tabular}

a A question mark indicates status uncertain.

b G-agents are the nerve agents GA (o-ethyl- $N, N$-dimethylphosphoramidacyanidate [tabun]), GB (isopropyl methylphosphonofluoridate [sarin], GD (pinacolyl methylphosphonofluoridate [soman]), and GF (cyclohexylmethylphosphonofluoridate). 
TABLE 2.23 Preliminary Identification of Contaminants of Potential Concern at the White Phosphorus Burning Pits and Other J-Field Sites ${ }^{\mathfrak{a}}$

Part I: White Phosphorus Burning Pits

Based on Analytical Data

Soil Gas

Trichloroethylene

Tetrachloroethylene

Simple aromatics

Other hydrocarbons
Soil

Barium

Chromium

Lead

Zinc

Nitrate

Petroleum hydrocarbons

Aromatics (?)

Cyanide

\section{Groundwater}

Nitrate

Cyanide

Dinitrotoluene

Nitrocellulose

RDX

1,3-Dithiane

Thiodiglycol

4-Chlorophenyl

methylsulfoxide

Trichloroethylene

Based on Site History

White phosphorus

Other chemicals (small amounts)

White phosphorus munitions

Part II: Other Sites ${ }^{b}$

Based on Analytical Data

Soil Gas

Heavy aromatics (RCP)

Phthalates (RCP)

DCE or TCE and TRCLE or

TCLEE (RCP)
Soil

Lead (RCP, PB)

Cadmium (PB)

Chromium ? (RCP)

DDD, DDE, DDT (PB)

Chlordane (SBT)

\section{Groundwater}

Zine ? (SBT, RPTS)

Cyanide (RCP, RPDG)

Benzene (RCP, PB)

Methyl isobutyl

ketone (RCP, PB)

Trichloroethane (RPTS)

Based on Site History

$\mathrm{CS}, \mathrm{CN}, \mathrm{DM}$, riot control

agents (RCP)

HE munitions (PB, SBDG)
HE, sensitive chemicals, CK ?, radium

and strontium-90 ? (RPDG, RPTS)

a A question mark indicates status uncertain.

b Codes in parentheses indicate sites involved: RCP = Riot Control Burning Pit, PB = Prototype Building, SBT $=$ South Beach Trench, RPTS = Robins Point Tower Site, RPDG = Robins Point Demolition Ground, SBDG = South Beach Demolition Ground. 
they are not based on sampling data. Surface water data are not included in the tables because relatively few contaminants were found. Where contaminants have been found in surface water, the contaminants of potential concern are the subset of volatile organics listed under the "groundwater" heading in Tables 2.22 and 2.23.

The information in the tables can be combined with a conceptual model for each site to determine the potential contaminants of concern for each environmental medium. For example, each contaminant listed in the soil-gas column would be expected, on the basis of site geohydrology, to be a contaminant of potential concern both for soil and groundwater. The table entries are discussed by site in the following sections.

\section{Toxic Burning Pits}

Analytical data show the presence of many contaminants of potential concern in the TBP AOC. Extensive plumes of soil gas contaminated with chlorinated solvents, aromatics, alkanes, and other organic materials that apparently originated from one or more of the various pits at the TBP have been detected. Soil samples show high concentrations (up to 2.6\%) of lead and lower concentrations of other metals. Low concentrations of VOCs (including TRCLE) were found, as were PCBs and some pesticides. However, it is reported that the pesticide measurements may represent "false positives" (Nemeth 1989). The trace amounts of BNAs detected in the soil do not justify listing them as contaminants of potential concern.

Analyses of standing water samples from the TBP AOC show lead and possibly mercury as contaminants of potential concern. Groundwater data show that many VOCs are present at sufficiently high concentrations to be contaminants of potential concern. Several of them, such as 12DCE, TRCLE, and vinyl chloride, are present at concentrations well above the federal MCL values. Metals, such as lead and arsenic, and nitrate are also present at concentrations above federal MCLs. Cyanide is also present. Mustard degradation products (up to $21 \mu \mathrm{g} / \mathrm{L}$ thiodiglycol) and explosives (up to $213 \mu \mathrm{g} / \mathrm{L}$ nitrocellulose) have been found in some of the wells near the pits. The radioactive species cesium-137 and strontium-90 are listed as contaminants of potential concern because elevated concentrations (up to $172 \mathrm{pCi} / \mathrm{L}$ ) were found in three wells (P3, JF51, and JF73) (USGS 1991).

The site history indicates the potential presence of additional contaminants for which sufficient analytical data are not available. These contaminants include CWAs, such as VX, G-agents, mustard, and incapacitating and smoke agents, as well as CWA degradation products (Tables 2.22 and 2.23). Although most of the CWAs at J-Field are expected to be degraded by now, they are included as contaminants of potential concern because of their extreme toxicity and their possible presence in UXO. 


\section{White Phosphorus Burning Pits}

Soil-gas data for the WPP AOC show the presence of some VOCs (such as TRCLE and TCLEE) and some aromatics. Soil data show the presence of metals, with lead concentrations up to $2,960 \mathrm{ppm}$. Other contaminants of potential concern found at the WPP include petroleum hydrocarbons, nitrate, cyanide, and possibly aromatic hydrocarbons. Total phosphorus was found to be elevated, and because the analytical data do not include the form of the measured phosphorus, the possibility that an appreciable fraction is present as WP must be considered. Lead and possibly sulfate are considered surface water contaminants of potential concern on the basis of analytical data for samples of standing water collected from the pits.

Groundwater data show that nitrate, cyanide, some explosives-related compounds, some mustard degradation products, and TRCLE are contaminants of potential concern. Existing data do not indicate the presence of PCBs or pesticides in the groundwater.

The site history indicates that WP munitions and other forms of WP may have been disposed of at the WPP AOC; therefore, WP is a contaminant of potential concern. WP may be present either in pure form or as PWP.

\section{Riot Control Burning Pit}

Because of soil-gas analysis results, heavy aromatics, phthalates, and some chlorinated solvents (DCE or TCE and TRCLE or TCLEE) are considered contaminants of concern at the RCP. Soil data show that lead and possibly chromium are contaminants of

potential concern. Insufficient data exist regarding organic materials as contaminants of potential concern in soil at the site.

Groundwater data indicate that cyanide, benzene, and methyl isobutyl ketone (MIBK) are contaminants of potential concern. Insufficient data exist to determine if volatile compounds and other organic compounds, including CWAs and CWA degradation products, are contaminants of potential concern.

The site history indicates that riot control agents such as adamsite (DM), chloroacetophenone (CN), and especially o-chlorobenzylidene malononitrile (CS) are contaminants of potential concern.

\section{Prototype Building}

Passive soil-gas studies indicate minor organic contamination in discrete areas east of the PB AOC. Soil data indicate that lead, cadmium, and pesticides (and their breakdown products, such as DDD, DDE, and DDT) are also contaminants of potential concern. Benzene and MIBK are contaminants of potential concern in groundwater. The site history suggests that explosives and contaminants in unspecified wastes, including the contents of the four drums presently on the site (Weston 1992), may be contaminants of potential concern. 


\section{South Beach Trench}

No data exist on soil-gas contamination at the SBT AOC. On the basis of one surface soil sample, chlordane is a contaminant of potential concern. Sampling data from one monitoring well ( $\mathrm{TH} 10$ ) indicate that zinc may be a contaminant of potential concern in the groundwater. Insufficient data are available to determine if other organic compounds or metals are contaminants of potential concern in either the soil or groundwater at the site.

Information on the site history and use is lacking. The presence of a few munitions fragments on the site (Nemeth 1989) is insufficient to suggest contaminants of potential concern.

\section{South Beach Demolition Ground}

Existing environmental data are insufficient to indicate the presence of any contaminants of potential concern at the SBDG AOC. In any case, most of the site is currently offshore and covered with sand. The site history of $\mathrm{HE}$ munitions demolition indicates that metals and explosives may be contaminants of potential concern.

\section{Robins Point Demolition Ground}

Existing environmental media (surface soil and surface water) sampling data do not support the listing of any contaminants of potential concern for the RPDG AOC; however, the site history indicates that explosives and possibly cyanide may be contaminants of potential concern. An item filled with cyanogen chloride (CK) was reportedly destroyed at the site, and cyanide is a degradation product of $\mathrm{CK}$.

\section{Robins Point Tower Site}

No sampling data exist on which to base the listing of contaminants of potential concern for soil gas or soil for the RPTS AOC. Groundwater data from two wells (TH11 and JF1) indicate that zinc and 111TCE may be contaminants of potential concern. Site history and use indicate it is possible that rocket fuel components and the radioactive species radium and strontium-90 may be contaminants of potential concern. The radioactive species could be present if the once-planned test burn of radioactively contaminated wood was actually conducted at the site.

\section{Other J-Field Sites}

Currently there are no chemical data to identify contaminants of potential concern at the PAOCs. 


\subsubsection{Present and Probable Future Land Use}

Current use of J-Field is limited to one $\mathrm{OB}$ area and two $\mathrm{OD}$ areas. These areas are operating under RCRA interim status. One area, a pan located about $50 \mathrm{~m}$ west of the PB is planned to be used to burn small amounts of propellants or explosives. One OD area is the RPDG, used to detonate munitions. The other area, near the WPP, is used for emergency detonation of items containing white phosphorus (WP).

It is currently anticipated that $O B / O D$ activities will continue at the three areas now in use. The levels of activities were reported in January 1991 to be one or two emergency disposal operations per year at the WPP AOC and about 100 days of operations per year at the RPDG AOC (ICF-Kaiser Engineers 1991). In addition, it is possible that non-RCRApermitted flashing of small quantities of explosives will be conducted at J-Field. These activities may include flashing of small amounts of explosives left in opened and cleaned shell casings. These actions are needed to certify that the casings are " $5 \mathrm{X}$ " clean. No CWAs will be disposed of at J-Field (Benioff 1992).

Hunting and trapping are not allowed at J-Field. Seasonal hunting of migratory birds is permitted along the entire shore of J-Field (Wrobel 1994). Areas of the Gunpowder River and Chesapeake Bay near J-Field are used for fishing from boats (ICF-Kaiser Engineers 1991). Access to the shore is prohibited.

The FS will evaluate the final remedial alternative selection for both restricted and unrestricted land use scenarios.

\subsubsection{Conceptual Site Model}

A conceptual site model that links sources and release mechanisms to receptors through various pathways and exposure routes for J-Field is presented in Figure 2.20. The model has been prepared on the basis of our current understanding of the contamination scenario at J-Field. It is based on the risk and biological impact assessment technical plan prepared by ICF-Kaiser Engineers (1993) and on existing data.

At this early stage of investigation, the proposed model shown in Figure 2.20 is applicable to each of the AOCs at J-Field. As additional data are gathered, it may be necessary to modify the model.

In the conceptual site model, the main sources of contamination are considered to be the eight AOCs. The primary release mechanisms associated with these AOCs are considered to be related to the primary waste-handling activities conducted at J-Field (i.e., $\mathrm{OB} / \mathrm{OD}$ ). Precipitation falling on the $\mathrm{OB} / \mathrm{OD}$ areas and other contaminated areas would cause the infiltration/percolation of contaminants. In addition, because operating procedures could have involved the addition of assorted fuels to facilitate $\mathrm{OB}$, infiltration and percolation of these fuels are also considered primary release mechanisms. 


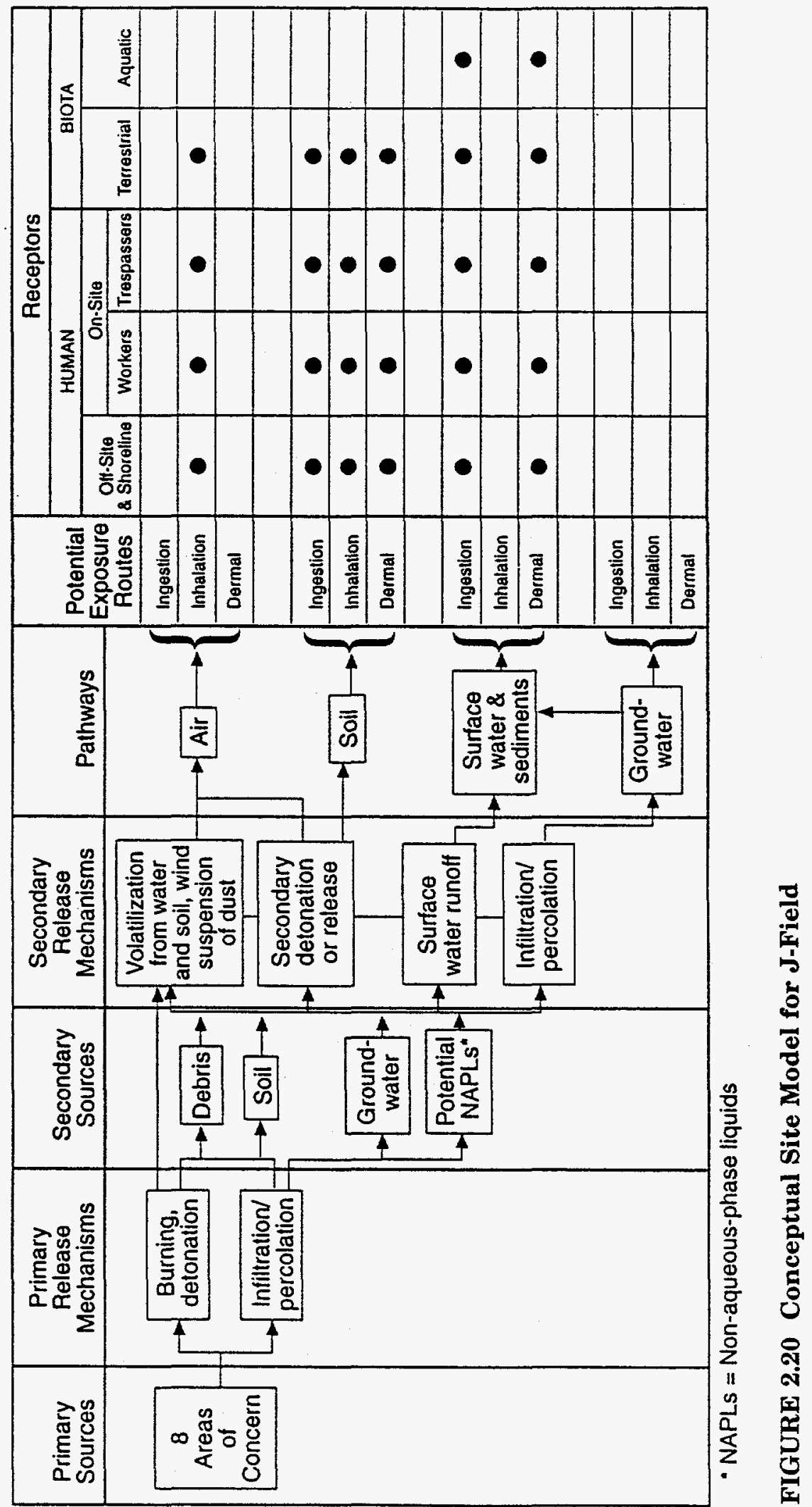


Because of the potential for soils at each AOC to have become contaminated through the primary release mechanisms, soil is considered one of the more significant secondary sources of contamination. Groundwater is also considered a significant secondary source of contamination because of the potential for contamination from infiltration and percolation. In addition, because of the nature of OB/OD activities, significant amounts of debris (such as exploded or unexploded ordnance) could exist within each AOC. Such debris could also represent a significant secondary source of contamination for the secondary release mechanisms.

Several processes have been identified as secondary release mechanisms in the exposure mode. Because of the potential existence of areas of contaminated soil and debris, an associated potential exists for the release of contaminants as dust and as volatilization products of contaminants into the air pathway from debris, soil, and/or groundwater. The discharge of groundwater into surface water bodies such as marshes and streams and into Chesapeake Bay, as suggested by thermal imagery studies, is a potentially significant release mechanism for groundwater into media with exposure routes to receptors.

Because of the possible existence of UXO, some potential exists for contaminants to be released to the soil or air pathways as a result of "secondary" detonations. Infiltration and percolation are also considered significant secondary release mechanisms because they can cause contaminants in soil and debris to migrate to groundwater or to surface water and sediments. Surface runoff can also be a significant mechanism for the release of contaminants to surface water, sediments, and to areas of previously uncontaminated soil.

Analysis of potential impacts to human receptors at J-Field is based on the current limited human activity. Robins Point is currently the main active site for demolition of munitions. Fishing and crabbing from boats occur just offshore, even though they are not permitted along the J-Field shoreline. Trapping and hunting occur at nearby I-Field, and hunting of migratory birds is approved for the area along the J-Field shoreline.

The conceptual site model (Figure 2.20) accounts for these activities by separating the human receptors into on-site (workers and trespassers) and off-site (hunters and fishermen) categories. Potential exposures of these receptors and of terrestrial and aquatic biota through different pathways and exposure routes are indicated in the figure by solid black dots.

No potential exposures are indicated for groundwater because no direct routes are likely. Groundwater is not used downgradient of J-Field; the nearest pumping well is about 4 mi distant across the Gunpowder River (Hughes 1993). The potential is minimal for dermal exposure of workers to groundwater while withdrawing samples from monitoring wells. Indirect exposure routes for groundwater by upwelling into Chesapeake Bay or discharge to marshes and streams are indicated in Figure 2.20 by a pathway arrow from groundwater to surface water and sediments. 


\subsubsection{Preliminary Remediation Goals}

PRGs for each environmental medium of concern and each site at J-Field are, in essence, preliminary estimates of cleanup levels that should be attained by conducting remedial actions. For surface water and groundwater, PRGs can be chosen to be based on ARARs. Commonly used ARARs consist of federal MCLs, nonzero maximum contaminant level goals (MCLGs), state water quality standards (SWQSs), and federal water quality criteria (FWQC). The choice among these values depends on the ultimate receptor, the availability of the chosen ARAR for the contaminant of concern, and similar factors. For example, for water that is a current or potential source of drinking water, FWQC may have to be used for those parameters for which no MCL, nonzero MCLG, or SWQS are available (EPA 1991b). For pathways for which aquatic life in the marshes or estuaries is the ultimate receptor, freshwater or marine criteria can be used as cleanup levels.

Surface water and groundwater ARARs applicable to the J-Field contaminants of potential concern, except CWA and CWA degradation products, are summarized in Table 2.24. Some available data for CWA and CWA degradation products are provided in Table 2.25 As the tables show, very few water pathways criteria are available for many explosives-related compounds, CWA, and CWA degradation products. Atmospheric criteria for CWA, given in Table 2.25, can be used for atmospheric pathways for workers, which were selected for baseline risk assessment by ICF-Kaiser Engineers (1991).

Chemical-specific ARARs for soils, which are needed to establish cleanup levels, are generally not available (EPA 1991b). The water quality criteria and other standards can be used to develop soil cleanup levels. However, this procedure requires model calculations for each exposure pathway considered. For groundwater pathways to the marshes or estuaries, the model evaluates the contaminant moving down through the vadose zone, entering and mixing with the groundwater, being transported to the point of discharge, and mixing with marsh or estuary water at the discharge point. For each step, a transfer or dilution factor is determined by the model. Use of these model calculations gives soil cleanup levels as concentrations that will result in water concentrations at or below the selected criteria for the site, exposure pathway, and chemical parameter considered. Similar types of transfer factors or dilutions are needed for the surface water and air pathways.

The information currently available for J-Field is not sufficient to carry out model calculations to estimate soil cleanup levels. In addition, very little information is available on which to base an estimate of the significance of the different exposure pathways. Such is especially the case for CWA, for which very little data are available. Therefore, the use of even very simplified model equations requiring estimates for transfer and dilution factors as inputs would result in such crude estimates as to be potentially misleading and useless. For these reasons, preliminary estimates will not be given here of the soil cleanup levels for contaminants of concern for each of the sites at J-Field. It is expected that the collection of additional data will enable such estimates to be made. 
TABLE 2.24 Federal Water Quality Criteria, Standards, and Guidelines for Contaminants of Potential Concern at J-Field ${ }^{\text {a }}$

\begin{tabular}{|c|c|c|c|c|c|c|c|c|c|}
\hline \multirow[b]{5}{*}{ Parameter } & \multirow[b]{5}{*}{ MCL } & \multicolumn{8}{|c|}{ Concentrations ( $\mu \mathrm{g} / \mathrm{L}$, except as noted) } \\
\hline & & \multicolumn{4}{|c|}{ Human Health } & & & & \\
\hline & & \multicolumn{2}{|c|}{ Water Ingestion } & \multicolumn{2}{|c|}{ Fish Ingestion } & \multicolumn{4}{|c|}{ Aquatic Life } \\
\hline & & \multirow{2}{*}{$\begin{array}{l}\text { Threshold } \\
\text { Toxicity } \\
\text { Protection }\end{array}$} & \multirow{2}{*}{$\begin{array}{c}10^{-6} \\
\text { Cancer } \\
\text { Risk }\end{array}$} & \multirow{2}{*}{$\begin{array}{l}\text { Threshold } \\
\text { Toxicity } \\
\text { Protection }\end{array}$} & \multirow{2}{*}{$\begin{array}{c}10^{-6} \\
\text { Cancer } \\
\text { Risk }\end{array}$} & \multicolumn{2}{|c|}{ Freshwater } & \multicolumn{2}{|c|}{ Marine } \\
\hline & & & & & & Acute & Chronic & Acute & Chronic \\
\hline \multicolumn{10}{|c|}{ Metals and Inorganic Compounds } \\
\hline Arsenic & 50 & $-b$ & 0.025 & - & 0.0175 & $\begin{array}{l}850(\mathrm{~V})^{\mathrm{c}} \\
360(\mathrm{III})\end{array}$ & $\begin{array}{l}48(\mathrm{~V})^{\mathrm{c}} \\
190(\mathrm{III})\end{array}$ & $\begin{array}{l}2,319(\mathrm{~V})^{\mathrm{c}} \\
69(\mathrm{III})\end{array}$ & $\begin{array}{l}13(\mathrm{~V})^{\mathrm{c}} \\
36(\mathrm{III})\end{array}$ \\
\hline Barium & 1,000 & - & - & - & - & - & - & - & - \\
\hline Cadmium & 10 & 10 & - & - & - & $3.9^{\mathrm{d}}$ & $1.1^{\mathrm{d}}$ & 43 & 9.3 \\
\hline Chromium & 50 & $\begin{array}{l}50(\mathrm{VI}) \\
179,000(\text { III })\end{array}$ & - & $\overline{3.4} \times 10^{6}(\mathrm{III})$ & - & $\begin{array}{l}16 \text { (VI) } \\
1,700\left(\text { IIII }^{d}\right. \\
210 \text { (III) }^{d}\end{array}$ & $11(\mathrm{VI})$ & $\begin{array}{l}1,100 \text { (VI) } \\
10,300 \text { (III) }^{\mathrm{c}}\end{array}$ & $50(\mathrm{VI})$ \\
\hline Lead & 50 & 50 & - & 50 & - & $82^{\mathrm{d}}$ & $3.2^{\mathrm{d}}$ & 140 & 5.6 \\
\hline Mercury & 2 & 10 & - & 0.146 & - & 2.4 & 0.012 & 2.1 & 0.025 \\
\hline Nickel & - & 15.4 & - & 100 & - & $1,800^{d}$ & $96^{\mathrm{d}}$ & 140 & 7.1 \\
\hline Selenium & 10 & 10 & - & - & - & 260 & 35 & 410 & 54 \\
\hline Zinc & $5,000^{e}$ & 5,000 & - & - & - & $320^{\mathrm{d}}$ & 47 & 170 & 58 \\
\hline Cyanide & 200 & 200 & - & - & - & 22 & 5.2 & 1 & 1 \\
\hline Nitrate (as N) & 10,000 & - & - & - & - & - & - & - & - \\
\hline Sulfate & $250,000^{\mathrm{e}}$ & - & - & - & - & - & - & - & - \\
\hline \multicolumn{10}{|c|}{ Volatile Organic Compounds } \\
\hline Carbon tetrachloride & 5 & - & 0.42 & - & 6.94 & $35,200^{\mathrm{c}}$ & - & $50,000^{c}$ & - \\
\hline Chloroform & 100 & - & 0.19 & - & 15.7 & $28,900^{\mathrm{c}}$ & $1,240^{\mathrm{c}}$ & - & - \\
\hline Ethyl benzene & 700 & 2,400 & - & 3,280 & - & $32,000^{c}$ & - & $430^{c}$ & - \\
\hline 1,1-Dichloroethylene & 7 & - & 0.033 & - & 1.85 & $11,600^{\mathrm{c}}$ & - & $224,000^{\mathrm{c}}$ & - \\
\hline
\end{tabular}




\begin{tabular}{|c|c|c|c|c|c|c|c|c|c|}
\hline \multirow[b]{5}{*}{ Parameter } & \multirow[b]{5}{*}{ MCL } & \multicolumn{8}{|c|}{ Concentrations $(\mu \mathrm{g} / \mathrm{L}$, except as noted) } \\
\hline & & \multicolumn{4}{|c|}{ Human Health } & & & & \\
\hline & & \multicolumn{2}{|c|}{ Water Ingestion } & \multicolumn{2}{|c|}{ Fish Ingestion } & \multicolumn{4}{|c|}{ Aquatic Life } \\
\hline & & \multirow{2}{*}{$\begin{array}{l}\text { Threshold } \\
\text { Toxicity } \\
\text { Protection }\end{array}$} & \multirow{2}{*}{$\begin{array}{c}10^{-6} \\
\text { Cancer } \\
\text { Risk }\end{array}$} & \multirow{2}{*}{$\begin{array}{l}\text { Threshold } \\
\text { Toxicity } \\
\text { Protection }\end{array}$} & \multirow{2}{*}{$\begin{array}{c}10^{-6} \\
\text { Cancer } \\
\text { Risk }\end{array}$} & \multicolumn{2}{|c|}{ Freshwater } & \multicolumn{2}{|c|}{ Marine } \\
\hline & & & & & & Acute & Chronic & Acute & Chronic \\
\hline \multicolumn{10}{|c|}{ Volatile Organic Compounds (Cont.) } \\
\hline 1,1-Dichloroethylene & 7 & - & 0.033 & - & 1.85 & $11,600^{\mathfrak{c}}$ & - & $224,000^{\mathrm{c}}$ & - \\
\hline Toluene & 1,000 & 15,000 & - & 424,000 & - & $17,500^{\mathrm{c}}$ & - & $6,300^{\mathrm{c}}$ & $5,000^{\mathrm{c}}$ \\
\hline Methylisobutylketone & - & - & - & - & - & - & - & - & - \\
\hline 112TCE & 5 & - & 0.60 & - & 41.8 & - & $9,400^{c}$ & - & - \\
\hline 12DCE & $\begin{array}{l}70(\text { cis }) \\
100(\text { trans })\end{array}$ & - & - & - & - & 11,600 & - & 224,000 & - \\
\hline Vinyl chloride & 2 & - & 2 & - & 525 & - & - & - & - \\
\hline TRCLE & 5 & - & 2.8 & - & 80.7 & $45,000^{c}$ & $21,900^{c}$ & 2,000 & - \\
\hline TCLEA & - & - & 0.17 & - & 10.7 & - & $2,400^{c}$ & $9,020^{C}$ & - \\
\hline TCLEE & 5 & - & 0.88 & - & 8.85 & $5,280^{\mathrm{c}}$ & $840^{c}$ & $10,000^{c}$ & $450^{\mathrm{c}}$ \\
\hline Benzene & 5 & - & 0.67 & - & 40 & $5,300^{\mathrm{c}}$ & - & $5,100^{c}$ & $700^{c}$ \\
\hline Monochlorobenzene & 100 & 488 & - & - & - & $250^{\mathrm{c}}$ & $50^{\mathrm{c}}$ & $160^{c}$ & $129^{c}$ \\
\hline \multicolumn{10}{|c|}{ Semivolatile Organic Compounds } \\
\hline PAHs & - & - & 0.0031 & - & 0.031 & - & - & $300^{\mathrm{c}}$ & - \\
\hline Phthalates & - & - & - & - & - & $940^{c}$ & $3^{\mathbf{c}}$ & 2,944 & $3.4^{\mathrm{c}}$ \\
\hline $\begin{array}{l}\text { Petroleum } \\
\text { hydrocarbons }\end{array}$ & - & - & - & - & - & - & - & - & - \\
\hline \multicolumn{10}{|l|}{ Pesticides, PCBs } \\
\hline Chlordane & 2 & - & 0.022 & - & 0.00048 & 2.4 & 0.0043 & 0.09 & 0.004 \\
\hline Heptachlor & 0.4 & - & 0.011 & - & 0.00029 & 0.528 & 0.003 & 0.053 & 0.0036 \\
\hline Heptachlorepoxide & 0.2 & - & - & - & 0.00029 & - & - & - & - \\
\hline DDD & - & - & - & - & - & - & - & - & - \\
\hline DDE & - & - & - & - & - & $1,050^{\mathrm{c}}$ & - & $14^{\mathrm{c}}$ & - \\
\hline DDT & - & - & 0.0012 & - & 0.000024 & 1.1 & 0.001 & 0.13 & 0.001 \\
\hline PCBs & 0.5 & - & 0.013 & - & 0.000079 & 2.0 & 0.014 & 10 & 0.03 \\
\hline
\end{tabular}


TABLE 2.24 (Cont.)

\begin{tabular}{|c|c|c|c|c|c|c|c|c|c|}
\hline \multirow[b]{5}{*}{ Parameter } & \multicolumn{9}{|c|}{ Concentrations ( $\mu \mathrm{g} / \mathrm{L}$, except as noted) } \\
\hline & \multirow[b]{4}{*}{ MCL } & \multicolumn{4}{|c|}{ Human Health } & & & & \\
\hline & & \multicolumn{2}{|c|}{ Water Ingestion } & \multicolumn{2}{|c|}{ Fish Ingestion } & \multicolumn{4}{|c|}{ Aquatic Life } \\
\hline & & \multirow{2}{*}{$\begin{array}{l}\text { Threshold } \\
\text { Toxicity } \\
\text { Protection }\end{array}$} & \multirow{2}{*}{$\begin{array}{c}10^{-6} \\
\text { Cancer } \\
\text { Risk }\end{array}$} & \multirow{2}{*}{$\begin{array}{l}\text { Threshold } \\
\text { Toxicity } \\
\text { Protection }\end{array}$} & \multirow{2}{*}{$\begin{array}{c}10^{-6} \\
\text { Cancer } \\
\text { Risk }\end{array}$} & \multicolumn{2}{|c|}{ Freshwater } & \multicolumn{2}{|c|}{ Marine } \\
\hline & & & & & & Acute & Chronic & Acute & Chronic \\
\hline \multicolumn{10}{|c|}{ Explosives-Related Compounds } \\
\hline 2,4-Dinitrotoluene & - & - & $0.05^{\mathrm{f}}$ & - & 9.1 & $330^{c, g}$ & $230^{\mathrm{c}, \mathrm{g}}$ & $590^{c, g}$ & $370^{c, g}$ \\
\hline 2,6-Dinitrotoluene & - & - & $0.05^{\mathrm{f}}$ & - & - & - & - & - & - \\
\hline TNT & - & $2^{f}$ & - & - & - & - & - & - & - \\
\hline HMX & & $400^{f}$ & - & - & - & - & - & - & - \\
\hline $\operatorname{RDX}$ & - & $2^{\mathrm{f}}$ & - & - & - & - & - & - & - \\
\hline 1,3,5-Trinitrobenzene & - & - & - & - & - & - & - & - & - \\
\hline 1,3-Dinitrobenzene & - & $1^{\mathrm{f}}$ & - & - & - & - & - & - & - \\
\hline Nitrobenzene & - & 19,800 & - & - & - & $27,000^{\mathrm{c}}$ & - & $6,680^{\mathrm{c}}$ & - \\
\hline Nitroglycerin & & $5^{f}$ & - & - & - & - & - & - & - \\
\hline Nitrocellulose & - & Nontoxic & - & - & - & - & - & - & - \\
\hline $\begin{array}{l}\text { Pentaerythritol- } \\
\text { tetranitrate }\end{array}$ & - & - & - & - & - & - & - & - & - \\
\hline Tetrazene & - & - & - & - & - & - & - & - & - \\
\hline $\begin{array}{l}\text { 2,4,6-Trintrobenz- } \\
\text { aldehyde }\end{array}$ & - & - & - & - & - & - & - & - & - \\
\hline Tetryl & - & - & - & - & - & - & - & - & - \\
\hline $\begin{array}{l}\text { 2,4,6-Trinitrophenyl } \\
\text { methylnitramine }\end{array}$ & - & - & - & - & - & - & - & - & - \\
\hline \multicolumn{10}{|l|}{ other ${ }^{h}$} \\
\hline Thiodiglycol & - & - & - & - & - & $8.2 \times 10^{7}, \mathrm{i}$ & - & $6.8 \times 10^{5}, \mathrm{i}$ & - \\
\hline VX & - & - & - & - & - & $0.3^{\mathrm{i}}$ & - & $0.3^{\mathrm{i}}$ & - \\
\hline 1,4-Dithiane & - & - & - & - & - & $1.2 \times 10^{5}$ & - & $26,500^{\mathrm{i}}$ & - \\
\hline White phosphorus & - & $0.1^{\mathrm{f}}$ & - & - & - & - & - & - & - \\
\hline $\begin{array}{l}\text { Diisopropyl methyl- } \\
\text { phosphonate }\end{array}$ & - & $600^{f}$ & - & - & - & - & - & - & - \\
\hline
\end{tabular}

See footnotes on next page. 


\section{TABLE 2.24 (Cont.)}

a In the body of the table, roman numerals in parentheses represent the valence state of the element.

b $\quad$ A "-" = value not available.

c Insufficient data to develop criteria. Value given is lowest observed effect level.

d Hardness-dependent criteria; value is for $100 \mathrm{mg} / \mathrm{L}$.

e Secondary MCL.

$f$ Lifetime health advisory for adults or $10^{-6}$ cancer risk (EPA 1992c).

g Reported value is for dinitrotoluene, isomer unspecified.

h Only those CWAs and degradation products are listed for which water quality data are available.

i $96 \mathrm{H}-\mathrm{LC}_{50}$ values $-50 \%$ of organisms will die in $96 \mathrm{~h}$ (ICF-Kaiser Engineers 1994).

Source: EPA (1986) unless otherwise specified. 
TABLE 2.25 Atmospheric Criteria for Chemical Warfare Agents that Are Contaminants of Potential Concern at J-Field

\begin{tabular}{|c|c|c|}
\hline \multirow[b]{2}{*}{ Chemical Warfare Agent } & \multicolumn{2}{|c|}{ Recommended Exposure Limit ${ }^{\mathrm{a}}\left(\mathrm{mg} / \mathrm{m}^{3}\right)$} \\
\hline & $\begin{array}{c}\text { Time-Weighted } \\
\text { Average }\end{array}$ & $\begin{array}{l}\text { Immediately } \\
\text { Dangerous to Life } \\
\text { and Health }\end{array}$ \\
\hline \multicolumn{3}{|l|}{ Lethal Chemical Agents } \\
\hline $\begin{array}{l}\text { Tabun (GA) } \\
\text { Sarin (GB) } \\
\text { Soman (GD) } \\
\text { VX } \\
\text { Mustard (H, HD, HT) } \\
\text { Lewisite (L) }\end{array}$ & $\begin{array}{r}-^{\mathrm{b}} \\
0.0001 \\
0.00003 \\
0.00001 \\
0.003 \\
0.0001^{\mathrm{c}}\end{array}$ & $\begin{array}{r}0 . \overline{2} \\
-\overline{4} \\
0.4 \\
0.5 \\
-\end{array}$ \\
\hline \multicolumn{3}{|l|}{ Incapacitating Agents } \\
\hline $\begin{array}{l}\text { Adamsite (DM) } \\
\text { Chloroacetophenone (CN) } \\
\text { o-Chlorobenzylidene malonitrile (CS) } \\
\text { 3-Quinuclidinyl benzilate (BZ) }\end{array}$ & $\begin{array}{r}- \\
- \\
0.004\end{array}$ & $\begin{array}{l}- \\
- \\
-\end{array}$ \\
\hline \multicolumn{3}{|l|}{ Blood Agents } \\
\hline Cyanogen chloride (CK) & - & - \\
\hline \multicolumn{3}{|l|}{ Smoke/Incendiary Agents } \\
\hline $\begin{array}{l}\text { Titanium tetrachloride (FM) } \\
\text { Sulfur trioxide-chlorosulfonic } \\
\text { acid (FS) }\end{array}$ & - & - \\
\hline White phosphorus (WP) & 0.1 & 200 \\
\hline
\end{tabular}

a As recommended by the Surgeon General for the work place.

b $\mathrm{A}$ "-" = not applicable.

c Value is a ceiling.

Source: Weston (1992). 


\subsubsection{Preliminary Identification of Operable Units}

Operable units are portions of an overall response action that eliminate or mitigate a release, threat of release, or an exposure pathway. An operable unit may be implemented as a final remediation for a defined portion of a site or as an interim action before the RI/FS is completed, as in the case of the soil and groundwater at the TBP (to be documented in the J-Field Focused Feasibility Study [FFS] Report). Those operable units implemented as interim actions are generally followed by long-term remediation.

Operable units are usually defined on the basis of the locations of "hot spots" (locations of significantly elevated contaminant concentrations), the site geology, the chemical and physical nature of contamination, and the extent and location of threats to human health and the environment. At J-Field, the following preliminary operable units have been identified:

- Implementing Toxic Burning Pits Interim Remedial Action - the FFS for the TBP AOC will address soil contamination in the two main pits and associated pushout area (but will not include the marsh) and groundwater in the surficial aquifer in the general TBP AOC vicinity;

- Remediating soil contamination at all OB/OD pits and pushout areas;

- Remediating soil contamination at the PB;

- Remediating soil contamination at PAOCs;

- Remediating sediment and surface water contamination in the marshes;

- Remediating groundwater contamination in the surficial aquifer; and

- Remediating groundwater contamination in the confined aquifer.

The necessity of remediating the areas mentioned here will be evaluated during the FS once the baseline risk assessment and the RI are complete. The FS will evaluate remediation alternatives to address the contamination at those areas considered to warrant remedial action. 


\section{FEASIBILITY STUDY TASKS}

In general, the FS process can be separated into two phases: (1) development and screening of alternatives; and (2) detailed analysis of alternatives. Alternatives will be developed concurrently with the RI site characterization activities. This process is iterative, with the results of the RI aiding in the development of alternatives and screening of technologies and the range of alternatives guiding subsequent site characterization and treatability studies.

The FS will consist of eight tasks:

- Task 1: Development of Remedial Action Objectives and General Response Actions,

- Task 2: Identification of Remedial Action Technologies and Assembly of Alternatives,

- Task 3: Screening of Remedial Action Alternatives,

- Task 4: Performance of Treatability Studies,

- Task 5: Detailed Analysis of Alternatives,

- Task 6: Cost Analysis,

- Task 7: Selection of Preferred Alternative, and

- Task 8: FS Report Preparation.

Each of these tasks is described in the following sections.

\subsection{TASK 1: DEVELOPMENT OF REMEDIAL ACTION OBJECTTVES AND GENERAL RESPONSE ACTIONS}

\subsubsection{Development of Remedial Action Objectives}

Remedial action objectives to address contaminants of concern, potential exposure pathways, and remediation goals for this FS have been developed for J-Field on the basis of available information. These objectives consist of specific goals for protecting human health and the environment and are as follows:

- To protect human health and the environment by developing response actions that mitigate chemical contamination in various media at J-Field; 
- To minimize contaminant migration to off-site areas;

- To institute solutions for contaminated media that permanently or significantly reduce their toxicity, mobility, or volume;

- To implement actions in a manner that ensures compliance with ARARs; and

- To implement actions in a manner that ensures minimum impact to human health and the environment.

\subsubsection{Development of General Response Actions}

General response actions (e.g., no action, treatment, containment, removal) have been developed to meet the objectives specified in Section 3.1.1. Currently available information indicates that the main source of contamination at J-Field is soil that has been contaminated by disposal activities. Table 3.1 lists response actions and associated remedial technologies and process options to address sources of contamination in soil at J-Field. Because some simultaneous remediation of groundwater and surface water may be required, response action categories and associated technologies for these media have also been identified (Tables 3.2 and 3.3). Remediation of the soil and groundwater will be approached by development of limited remedial alternatives that will allow for quick action on the basis of limited design information, with larger-scale actions to follow.

Existing data will be used to identify site conditions that may limit or promote the use of certain response actions. Table 3.4 lists site characteristics that will be evaluated during this process. Response actions that are precluded by site characteristics or identified as not applicable on the basis of increased understanding of site conditions will be eliminated from further consideration. This process will include identification of waste characteristics that limit the effectiveness or applicability of certain technologies. Such waste characteristics include the following:

- Contaminant concentration,

- Toxicity of contaminant,

- Radiological characteristics,

- Chemical composition and characteristics,

- Persistence of contaminant,

- Mixture of contaminants, and

- Presence of UXO or CWAs. 
TABLE 3.1 General Response Actions and Technology Types for Soil and Sediment

General Response Action/

Potential Technology Type

Potential Process Option

Remediation Goal

\section{No Action}

Not applicable

\section{Institutional Control}

Access restrictions

Use restrictions

Monitoring

\section{Containment}

Surface controls/diversions

Capping

Lateral barriers

Bottom sealing

\section{Removal}

Excavation

Dredging
Not applicable

Fences and guards

Legal titles and deeds

Soil samplers, surface water samplers, groundwater wells

Graded contours, swales, berms, soil stabilization

Clay cap, riprap, asphalt or concrete, synthetic membrane material, or combination

Slurry wall, grout curtain, sheet piling, cryobarriers

Grout layer injection, block displacement, cryobarriers

Backhoe, bulldozer, scraper and front end loader, dragline, power shovel, clamshell, rotary drilling, trenching, hand excavation

Cutting head, clamshell, dragline
No-action alternative is included to provide a baseline for comparison with other alternatives.

Limit potential human exposure to all contaminants.

Limit potential human exposure to all contaminants.

Provide data for assessing potential for exposure.

Limit contaminant migration from contaminated area and minimize potential human and ecological exposure from contaminant migration.

Limit contaminant migration from contaminated area and minimize potential human and ecological exposure from contaminant migration.

Limit contaminant mobility and mitigate potential exposure from contaminant migration.

Limit contaminant mobility and mitigate potential exposure from contaminant migration.

Eliminate potential exposure by removing contaminated source material from the environment (material must be further managed).

Eliminate potential exposure by removing contaminated source material from the environment (material must be further managed). 
TABLE 3.1 (Cont.)

General Response Action

Potential Technology Type

\section{Removal (Cont.)}

Pumping (wet sediments or

slurried soil)

\section{In Situ Treatment}

Physical/Chemical

Dewatering/drying

Vapor extraction

Liquid extraction

Chemical transformation

Solidification/Stabilization

Thermal

Thermal extraction
Centrifugal, reciprocating, and positive

displacement pumps

Solar evaporation, gravity drainage trenches

Soil vapor extraction, air stripping, soil venting, air sparging, vacuum extraction

Aqueous soil flushing, surfactant flushing, hydraulic fracturing to enhance fluid and vapor flow in subsurface

Hydrolysis, oxidation/reduction reactions, neutralization, precipitation, electrokinetics, electrochemical reduction and immobilization, photochemical

Lime-based and Portland cement-based pozzolanic reaction, silicates, sorbents, chemical immobilization

Thermally enhanced vapor extraction, steam/hot water injection, steam/hot air extraction, radio frequency heating, electrical resistance heating, soil heating
Eliminate potential exposures by removing contaminated source material from the environment (material must be further managed).

Limit contaminant mobility, reduce volume of contaminated materials, and transfer contaminants from liquid to solid or gas phase.

Removal of volatile organic contaminants from soil and sediment by transfer of contaminants to gaseous phase.

Enhance mobility of contaminants in aqueous phase to facilitate contaminant removal.

Reduce contaminant toxicity and/or mobility by transformation of contaminants to nonmobile or nontoxic forms.

Reduce contaminant mobility by fixation of primarily inorganic contaminants into stable solid matrix (soil or sediment volume typically increases)

Removal of volatile and semivolatile organic contaminants by mass transfer to the gaseous medium and reduction in contaminated soil volume. 
TABLE 3.1 (Cont.)

General Response Action/

Potential Technology Type

\section{In Situ Treatment (Cont.)}

Thermal (Cont.)

Thermal destruction

Vitrification

\section{Biological}

Passive

Active

\section{Ex Situ Treatment \\ Physical/Chemical \\ Dewatering/drying}

Particle separation

Volume reduction

Vapor extraction
Potential Process Option

Remediation Goal
Reduction of toxicity, mobility, and volume of contaminated soil or sediment; destruction of organic contaminants; and fixation of inorganic contaminants in vitrified soil. Total volume of contaminated material is typically reduced.

Aerobic and anaerobic: surface impoundments such as stabilization pits, lagoons, wetlands, vegetation-enhanced biodegradation,

biodegradation cells

Aerobic and anaerobic: injection and extraction well systems with pumping

Filtration, centrifugation, sedimentation, expression, drying bed, evaporation, electrokinetics

Screening, classification, gravity concentration and separation, magnetic separation, flotation, electrostatic separation, sediment washing

Crushers, shredders, pulverizers, tumbling and hammer mills, compaction

Low-temperature fluidized bed, soil venting
Reduction of contaminant toxicity and mobility through degradation of organic contaminants and reduction in contaminated soil or sediment volume.

Reduction of contaminant toxicity and mobility through degradation of organic contaminants and reduction in contaminated soil or sediment volume.

Limit contaminant mobility by removal of liquid phase, reduce volume of contaminated materials, and transfer contaminants from liquid to solid or gas phase.

Reduce volume of contaminated soil or sediment by removal of fraction that contains majority of contamination (used as pretreatment step before application of other treatment technologies).

Reduce contaminated soil or sediment volume (used as pretreatment step before application of other treatment technologies).

Removal of volatile organic contaminants from soil and sediment by transfer of contaminants to gas phase. 
TABLE 3.1 (Cont.)

General Response Action/

Potential Technology Type

Ex Situ Treatment (Cont.)

Physical/Chemical (Cont.)

Liquid extraction

Chemical transformation

Stabilization/solidification

Thermal

Thermal extraction

Thermal destruction

\section{Biological \\ Composting}

Land application
Soil washing, solvent extraction, selective extraction, acid leaching, heap leach mining

Dechlorination, dehalogenation, hydrolysis, oxidation and reduction, neutralization, precipitation, dissolution, electrokinetics, chemical binding, chelation, photochemical

Pozzolanic processes, thermoplastic encapsulation, silicate and adsorbent binding, chemical immobilization

Low- and high-temperature stripping, thermal vacuum desorption, vacuum pyrolysis, anaerobic thermal processor

Incineration (slagging, fluidized bed, rotary kiln, infrared, multiple hearth), vitrification, pyrolysis, molten salt oxidation, supercritical water oxidation, cyclone furnace, hightemperature thermal processor, entrained bed gasification, gas phase reduction, plasma torch furnace, circulating bed combustor, flash smelting, catalytic extraction

Open and static windrows and reactor vessels

Land farming
Enhance mobility of contaminants in aqueous phase to facilitate contaminant removal.

Reduce contaminant toxicity and/or mobility by transformation of contaminants to nonmobile or nontoxic forms.

Reduce contaminant mobility by fixation of primarily inorganic contaminants into stable solid matrix (soil or sediment volume typically increases).

Removal of volatile and semivolatile organic contaminants by mass transfer to the gaseous medium and reduction in contaminated soil volume.

Reduction of toxicity, mobility, and volume of contaminated soil or sediment; destruction of organic contaminants; and transfer of inorganic contaminants to reduced volume of treatment residual (ash, slag, glass) for further management. Total volume of contaminated material is reduced.

Reduction of contaminant toxicity and mobility through degradation of organic contaminants and reduction in contaminated soil or sediment volume.

Reduction of contaminant toxicity and mobility through degradation of organic contaminants and reduction in contaminated soil or sediment volume. 


\section{TABLE 3.1 (Cont.)}

\begin{tabular}{|c|c|c|}
\hline $\begin{array}{l}\text { General Response Action/ } \\
\text { Potential Technology Type }\end{array}$ & Potential Process Option & Remediation Goal \\
\hline \multicolumn{3}{|l|}{$\begin{array}{l}\text { Ex Situ Treatment (Cont.) } \\
\text { Biological (Cont.) }\end{array}$} \\
\hline Reactor & $\begin{array}{l}\text { Aerobic and anaerobic processes } \\
\text { Suspended growth: continuous and plug flow, } \\
\text { activated sludge }\end{array}$ & $\begin{array}{l}\text { Reduction of contaminant toxicity and mobility through } \\
\text { degradation of organic contaminants and reduction in } \\
\text { contaminated soil or sediment volume. }\end{array}$ \\
\hline & $\begin{array}{l}\text { Attached growth: biological contactor, trickling } \\
\text { filter, fixed-film fluidized bed }\end{array}$ & \\
\hline Disposal & $\begin{array}{l}\text { Engineered disposal facility, vault disposal, } \\
\text { landfill using synthetic and earth-based } \\
\text { materials }\end{array}$ & $\begin{array}{l}\text { Limit contaminant mobility by containment in permanent } \\
\text { disposal cells engineered to minimize contaminant } \\
\text { migration and to mitigate potential exposures from } \\
\text { contaminant migration or direct contact. }\end{array}$ \\
\hline
\end{tabular}


TABLE 3.2 General Response Actions and Technology Types for Groundwater

General Response Action/ Potential Technology Type

\section{No Action}

Not applicable

\section{Institutional Control}

Access restrictions

Use restrictions

Monitoring

\section{Containment}

Lateral barriers

Bottom sealing

Migration control

Surface controls/diversions

Capping

\section{Removal}

Interception

Remediation Goal

Not applicable

Fences and other barriers at wells or groundwater discharge points

Legal titles and deeds, drilling restrictions

Groundwater wells, surface water samplers

Slurry wall, grout curtain, sheet piling, cryobarriers, deep soil mixing, angled barriers

Grout layer injection, block displacement, cryobarriers, angled barriers

Pumping (injection and extraction wells), sorbent barriers, gravel layer drain and vapor vent

Graded contours, swales, berms, soil stabilization

Clay cap, riprap, asphalt or concrete, synthetic membrane material, or combination

Subsurface drains, interceptor/recovery trenches
No-action alternative is included to provide a baseline for comparison with other alternatives.

Limit potential human exposure to all contaminants.

Limit potential human exposure to all contaminants.

Provide data for assessing potential for exposure.

Limit contaminant mobility and mitigate potential exposure from contaminant migration.

Limit contaminant mobility and mitigate potential exposure from contaminant migration.

Limit migration of contaminated groundwater plume.

Limit contaminant migration from contaminated area(s) to groundwater.

Limit contaminant migration from contaminated area(s) to groundwater.

Eliminate potential exposures by removing contaminated groundwater from the environment (collected water must be further managed). 
TABLE 3.2 (Cont.)

General Response Action/ Potential Technology Type

\section{Removal (Cont.)}

Well extraction

\section{In Situ Treatment}

Physical/Chemical

Vapor extraction

Liquid extraction

Chemical transformation

Contact reaction system

\section{Thermal}

Thermal extraction

Potential Process Option

Remediation Goal

Recovery wells, wellpoints, suction wells, deep wells

Air stripping, air sparging, vacuum extraction, in-well aeration, dual phase extraction

Aqueous flushing, surfactant flushing, hydraulic fracturing to enhance fluid and vapor flow in subsurface, dual-phase extraction, free-product recovery.

Chemical injection to promote hydrolysis, oxidation/reduction reactions,

neutralization, precipitation, and

immobilization; electrokinetics,

electrochemical reduction

Trenches with in situ treatment systems, permeable treatment beds, funnel and gate treatment systems (in situ reactor cells powdered metal, granular activated carbon, resins)

Thermally enhanced vapor extraction, steam/hot air extraction, vacuum extraction, electrical resistance heating, dynamic underground stripping
Eliminate potential exposures by removing contaminated groundwater from the environment (collected water must be further managed)

Limit contaminant mobility, reduce volume of contaminated groundwater, and transfer volatile organic contaminants from liquid to gas phase.

Enhance mobility of contaminants in groundwater to facilitate contaminant removal.

Reduce contaminant toxicity and/or mobility by transformation of contaminants to nonmobile or nontoxic forms.

Reduce contaminant toxicity and/or mobility downgradient of groundwater flow by transformation of contaminants to nonmobile or nontoxic forms.

Removal of volatile and semivolatile organic contaminants by mass transfer to the gaseous medium and reduction in contaminated groundwater volume. 
TABLE 3.2 (Cont.)

General Response Action/

Potential Technology Type

\section{In Situ Treatment (Cont.) \\ Biological}

Passive

Active

\section{Ex Situ Treatment}

Physical/Chemical

Suspended solids removal

\section{Contaminant extraction}

\section{Vapor extraction}

Liquid-liquid extraction

Chemical transformation
Aerobic and anaerobic: in situ microbial filters, biodegradation cells as part of a contact reaction system, natural attenuation

Aerobic and anaerobic: nutrient and microbial injection with extraction well systems and pumping

Filtration, centrifugation, flocculation, freeze crystallization, sedimentation

Adsorption, osmosis, reverse osmosis, ultrafiltration, electrolysis, electrodialysis, ion exchange, membrane microfiltration, polymer adsorption

\section{Air stripping, evaporation}

Solvent extraction, selective extraction

Dechlorination, dehalogenation, hydrolysis, oxidation and reduction, neutralization, precipitation, coprecipitation, dissolution, electrokinetics, chemical binding, chelation, photochemical transformation, X-ray radiation, ultraviolet oxidation
Reduction of contaminant toxicity and mobility through degradation of organic contaminants and reduction in contaminated groundwater volume.

Reduction of contaminant toxicity and mobility through degradation of organic contaminants and reduction in contaminated groundwater volume.

Limit contaminant mobility by removal of contaminated solids, reduce volume of contaminated water, and transfer contaminants from liquid to solid phase.

Remove contaminants from water by transfer of contaminants to solid phase.

Removal of volatile organic contaminants from water by transfer of contaminants to gaseous phase.

Enhance mobility of contaminants in water to facilitate contaminant removal.

Reduce contaminant toxicity and/or mobility by transformation of contaminants to nonmobile or nontoxic forms. 
TABLE 3.2 (Cont.)

General Response Action/

Potential Technology Type

Ex Situ Treatment (Cont.)

Thermal

Thermal extraction

Thermal destruction

Biological

Reactor

Land application

Disposal

Potential Process Option

Remediation Goal

Removal of volatile and semivolatile organic contaminants by mass transfer to the gaseous medium and reduction in contaminated water volume.

distillation

Liquid-injection incineration, molten salt oxidation, supercritical water oxidation, wet air oxidation, photocatalytic oxidation (ultraviolet or natural light), thermal gas phase reduction

Aerobic and anaerobic processes

Suspended growth: continuous and plug flow, activated sludge, biomass beads

Attached growth: biological contactor, trickling filter, fixed-film fluidized bed

Land farming, spray irrigation, overland flow, constructed wetlands

Reinjection or discharge to land, surface water, or a water treatment facility
Reduction of toxicity, mobility, and volume of contaminated aqueous waste; destruction of organic contaminants; and transfer of inorganic contaminants to reduced volume of treatment residual for further management (total volume of contaminated water is reduced).

Reduction of contaminant toxicity and mobility through degradation of organic contaminants and reduction in contaminated water volume.

Reduction of contaminant toxicity and mobility through degradation of organic contaminants and reduction in contaminated water volume.

Disposal used in conjunction with treatment, which limits contaminant toxicity, mobility, and volume and mitigates potential exposure and contaminant migration by removal of contaminated groundwater from the environment. 
TABLE 3.3 General Response Actions and Technology Types for Surface Water

\begin{tabular}{|c|c|c|}
\hline $\begin{array}{l}\text { General Response Action/ } \\
\text { Potential Technology Type }\end{array}$ & Potential Process Option & Remediation Goal \\
\hline \multicolumn{3}{|l|}{ No Action } \\
\hline Not applicable & Not applicable & $\begin{array}{l}\text { No-action alternative is included to provide a baseline for } \\
\text { comparison with other alternatives. }\end{array}$ \\
\hline \multicolumn{3}{|l|}{ Institutional Control } \\
\hline Access restrictions & $\begin{array}{l}\text { Fences and other barriers at surface water } \\
\text { bodies or discharge points }\end{array}$ & Limit potential human exposure to all contaminants. \\
\hline Use restrictions & Legal titles and deeds & Limit potential human exposure to all contaminants. \\
\hline Monitoring & $\begin{array}{l}\text { Surface water samplers, sediment sampling, } \\
\text { groundwater wells }\end{array}$ & Provide data for assessing potential for exposure. \\
\hline \multicolumn{3}{|l|}{ Containment } \\
\hline Surface controls/diversions & Dikes, graded contours, swales, berms & $\begin{array}{l}\text { Limit contaminant migration from contaminated surface } \\
\text { water to soil, groundwater, or other surface water bodies. }\end{array}$ \\
\hline Lateral barriers & $\begin{array}{l}\text { Slurry wall, grout curtain, sheet piling, } \\
\text { cryobarriers, deep soil mixing, angled } \\
\text { barriers }\end{array}$ & $\begin{array}{l}\text { Limit contaminant mobility and mitigate potential } \\
\text { exposures from contaminant migration. }\end{array}$ \\
\hline Bottom sealing & $\begin{array}{l}\text { Grout layer injection, block displacement, } \\
\text { cryobarriers, angled barriers }\end{array}$ & $\begin{array}{l}\text { Limit contaminant mobility and mitigate potential } \\
\text { exposures from contaminant migration. }\end{array}$ \\
\hline \multicolumn{3}{|l|}{ Removal } \\
\hline Interception & $\begin{array}{l}\text { Drains, interceptor/recovery trenches, } \\
\text { skimming and sinker collection }\end{array}$ & $\begin{array}{l}\text { Eliminate potential exposures by removing contaminated } \\
\text { surface water from the environment (collected water must } \\
\text { be further managed). }\end{array}$ \\
\hline Pumping & $\begin{array}{l}\text { Centrifugal, reciprocating, and positive } \\
\text { displacement pumps }\end{array}$ & $\begin{array}{l}\text { Eliminate potential exposures by removing contaminated } \\
\text { surface water from the environment (collected water must } \\
\text { be further managed). }\end{array}$ \\
\hline
\end{tabular}




\section{TABLE 3.3 (Cont.)}

General Response Action/

Potential Technology Type

\section{In Situ Treatment}

Physical/Chemical

Nonthermal extraction

Chemical transformation

Thermal

Thermal extraction

Biological

Passive

Active

\section{Ex Situ Treatment}

Physical/Chemical

Suspended solids removal
Photolysis, filtration, clarification, flotation, flocculation, ultraviolet radiation,

sedimentation, free-product recovery

Chemical injection to promote hydrolysis, oxidation/reduction reactions,

neutralization, precipitation, chelation,

dechlorination, adsorption, and

immobilization; electrokinetics,

electrochemical reduction

Solar evaporation, enhanced solar evaporation

Aerobic and anaerobic: wetland systems, natural attenuation

Aerobic and anaerobic: nutrient and microbial injection with mixing systems and pumping

Filtration, centrifugation, flocculation, freeze crystallization, sedimentation
Limit contaminant mobility, reduce volume of contaminated surface water, and transfer contaminants from liquid to solid or gas phase.

Reduce contaminant toxicity and/or mobility by transformation of contaminants to nonmobile or nontoxic forms.

Removal of volatile and semivolatile organic contaminants by mass transfer to the gaseous medium and reduction in contaminated surface water volume.

Reduction of contaminant toxicity and mobility through degradation of organic contaminants and reduction in contaminated surface water volume.

Reduction of contaminant toxicity and mobility through degradation of organic contaminants and reduction in contaminated surface water volume.

Limit contaminant mobility by removal of contaminated solids, reduce volume of contaminated water, and transfer contaminants from liquid to solid phase. 


\section{TABLE 3.3 (Cont.)}

General Response Action/

Potential Technology Type

\section{Ex Situ Treatment (Cont.)}

Physical/Chemical (Cont.)

Contaminant extraction

Vapor extraction

Liquid-liquid extraction

Chemical transformation

Thermal

Thermal extraction

Thermal destruction
- Adsorption, osmosis, reverse osmosis, ultrafiltration, electrolysis, electrodialysis, ion exchange, membrane microfiltration, polymer adsorption

Air stripping, evaporation

Solvent extraction, selective extraction

Dechlorination, dehalogenation, hydrolysis, oxidation and reduction, neutralization, precipitation, coprecipitation, dissolution, electrokinetics, chemical binding, chelation photochemical transformation, X-ray radiation, ultraviolet oxidation, immobilization

Low- and high-temperature stripping, distillation

Liquid-injection incineration, molten salt oxidation, supercritical water oxidation, wet air oxidation, photocatalytic oxidation (ultraviolet or natural light), thermal gas phase reduction
Remove contaminants from water by transfer of contaminants to solid phase.

Removal of volatile organic contaminants from water by transfer of contaminants to gas phase.

Enhance mobility of contaminants in water to facilitate contaminant removal.

Reduce contaminant toxicity and/or mobility by

transformation of contaminants to nonmobile or nontoxic forms.

Removal of volatile and semivolatile organic contaminants by mass transfer to the gaseous medium and reduction in contaminated water volume.

Reduction of toxicity, mobility, and volume of contaminated aqueous waste; destruction of organic contaminants; and transfer of inorganic contaminants to reduced volume of treatment residual for further management (total volume of contaminated water is reduced). 


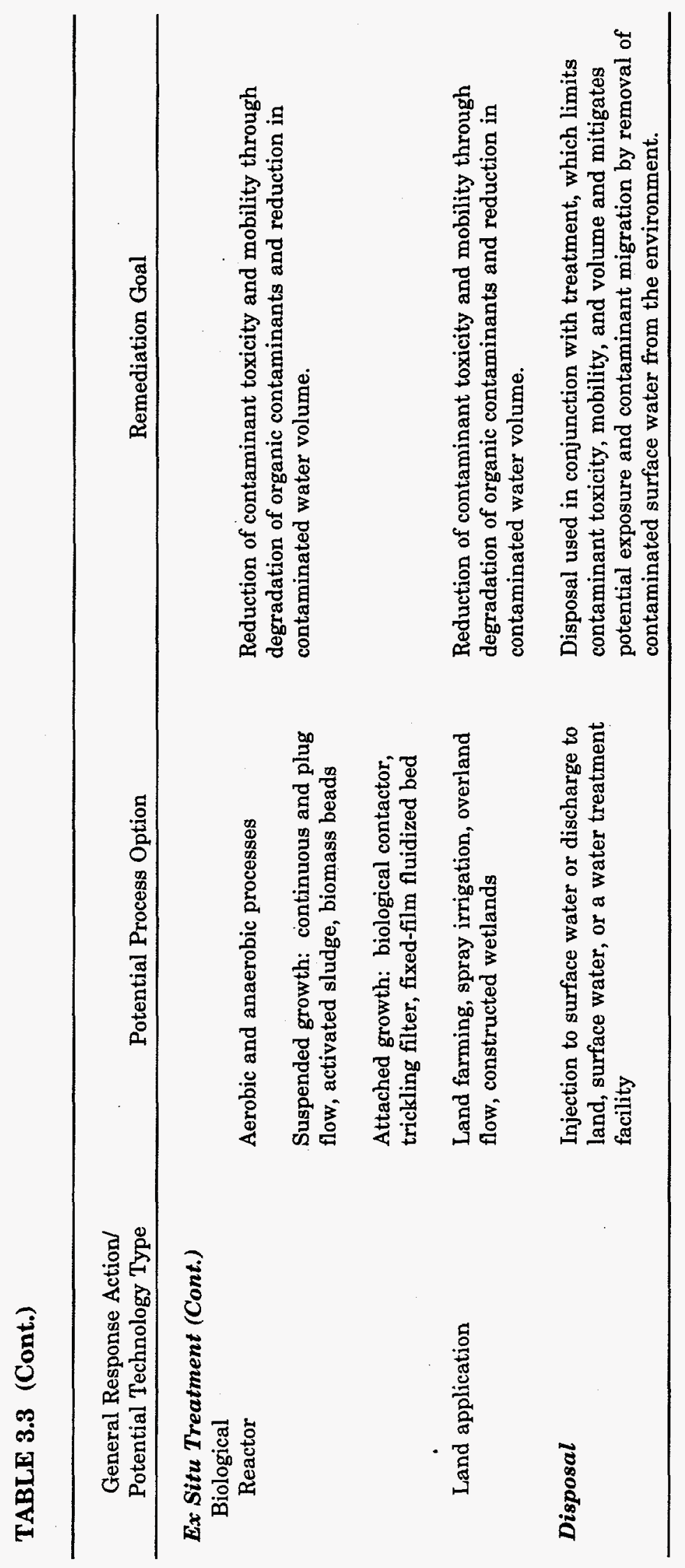


TABLE 3.4 Site Characteristics That May Affect Response Actions

- Volumes or areas of waste

- Site configuration

- Past disposal methods

- Climate

- Soil type

- Presence of surface water

- Existing land uses
- Depth to bedrock

- Depth to confining layers

- Direction and rate of groundwater flow

- Depth to groundwater

- Receptors

- Ecological factors

\subsection{TASK 2: IDENTIFICATION OF REMEDIAL ACTION TECHNOLOGIES AND ASSEMBLY OF ALTERNATIVES}

The CERCLA/SARA program permits remedial actions to be staged through multiple operable units, defined as discreet actions that comprise incremental steps toward the final remedy. The information developed in Task 1 (Section 3.1) will be used to assemble technologies ${ }^{1}$ into alternatives to remediate all identified operable units through removal and/or treatment of the sources of contamination.

Operable units include interim actions (e.g., pumping and treating groundwater to retard plume migration) that must be followed by subsequent actions to fully address the scope of the problem (e.g., a final groundwater operable unit that defines the remediation goals and restoration time frame for the site). This approach may be taken because of the need to respond to a pressing problem that will worsen if unaddressed, or because of an opportunity to undertake a limited action that will achieve significant risk reduction quickly. The concept of dividing remedial actions into operable units incorporates consideration of the interrelationship of site problems and recognizes the need or desire to initiate actions quickly when appropriate. Where the problems are reasonably separable, this phased response, implemented through operable units, promotes a more rapid reduction of risk.

As mandated by SARA, three principal categories of alternatives are to be considered: (1) containment with treatment, (2) containment without treatment, and (3) no action. The first category will include alternatives that encompass a range of options in which treatment is used to reduce the toxicity, mobility, or volume of wastes, but that vary in the degree to which long-term management of residuals or untreated waste is required.

1 For this work plan, the term treatment technologies refers to general categories, such as thermal destruction or chemical treatment. The term process options refers to specific processes within a technology, for example, the technology of thermal destruction includes incinerators, and process options within this technology deal with specific incinerator types (rotary kiln, fluidized bed, etc.). 
The second category will include one or more alternatives that incorporate containment with little or no treatment. The no-action alternative may include some site monitoring, but alternatives incorporating administrative or access controls (e.g., deed restrictions, site fencing) will be presented as limited action alternatives.

The universe of potentially applicable technology types and process options will be reduced in an initial screening through evaluation of technical feasibility (also referred to as implementability), effectiveness, and relative cost. The criteria for this initial screening will be applied only to technologies and the general response actions they are intended to satisfy, not to the site as a whole. Evaluation of technical feasibility will focus primarily on whether the technologies and process options will meet remedial action objectives.

Cost considerations will be limited to relative capital costs and operating and maintenance (O\&M) costs. Costs will be estimated on the basis of engineering judgment, with each option evaluated as high, medium, or low cost relative to other options in the same technology. During this phase, only costs associated with different general technology types will be considered.

Evaluation of technology effectiveness will include comparison of technology types and the potential effectiveness of process options to (1) handle the estimated areas or volumes of waste and meet remediation goals, (2) mitigate potential impacts to human health and the environment during construction and implementation, and (3) perform reliably with respect to the contaminants and conditions at the site. Additional site data may have to be collected for some media to adequately evaluate effectiveness.

\subsection{TASK 3: SCREENING OF REMEDIAL ACTION ALTERNATIVES}

Information developed in Tasks 1 and 2 will be screened to limit the number of alternatives evaluated during more detailed phases of the FS. This screening process will include refinement of the initial alternatives on the basis of any new information that becomes available, the baseline risk assessment (including the ecological risk assessment), and other site investigations. In this more in-depth phase, each alternative will be evaluated with respect to feasibility, effectiveness, and cost. Alternatives will also be evaluated to ensure that they will protect human health and the environment relative to potential pathways of concern and areas of the site being addressed as separate operable units. If practicable, the range of treatment and containment technologies initially developed will be preserved; however, if alternatives within a portion of this range are not feasible, they will be eliminated.

Evaluation of the feasibility (implementability) of alternatives will consider both technical and administrative feasibility. The evaluation of technical feasibility will address the ability to construct, reliably operate, meet technology-specific regulations, and effectively monitor components into the future. Evaluation of administrative feasibility will consider the ability to comply with the substantive requirements of any permits issued; availability 
of treatment, storage, and disposal services; and the requirements for, and availability of, specific equipment and technical specialists.

In terms of effectiveness, each alternative will be evaluated for its ability to (1) protect human health and the environment; (2) reduce toxicity, mobility, or volume (i.e., to effect changes in one or more characteristics of the hazardous substance that, as a result of treatment, decrease the inherent threats or associated risks); and (3) perform reliably with respect to the contaminants and conditions at the site. These elements will be evaluated for the construction and implementation periods (short-term effectiveness) and for the period after the remedial action is complete (long-term effectiveness).

Although cost factors are not as important as other criteria for selection of alternatives under CERCLA, they will be considered whenever the cost of an alternative far exceeds (by at least an order of magnitude) that of other alternatives without a demonstrated and equivalent difference in protectiveness, implementability, and reliability. Cost estimates will be developed for use in screening activities to the extent that comparisons of alternatives are possible. The estimates will be based on standard cost-estimating data, including cost curves, generic unit costs, vendor information, conventional cost-estimating guides, and estimates derived for similar sites (modified for site-specific information).

\subsection{TASK 4: PERFORMANCE OF TREATABILITY STUDIES}

Treatability studies will be performed, as appropriate, to collect additional data on technologies identified during the alternative development process and to determine the applicability of specific remedial technologies to site conditions and problems. The sufficiency of existing data to evaluate alternatives will be assessed to determine the need for treatability studies. Where possible, additional data needs will be identified through an expanded literature search with the following objectives:

- Determine whether the performances of the technologies under consideration have been sufficiently documented on similar wastes;

- Obtain information on relative costs, applicability, removal efficiencies, O\&M requirements, and implementability of the technologies; and

- Determine the testing requirements for conducting bench or pilot studies.

The decision to conduct treatability studies will ultimately be made by weighing the cost and time required to complete an investigation against the potential value of the information in resolving uncertainties associated with the selection of an alternative. Should treatability studies be required, a testing plan will be developed to identify the types of studies and their goals, the level of effort needed, and a schedule for completion. The datamanagement guidelines will be submitted to the Directorate of Safety, Health, and Environment at APG for review and approval and subsequent submittal to the EPA. 
During the testing, all management and quality control review activities will be implemented to ensure the quality of the data. Upon completion of the testing, the results will be evaluated to assess the technologies with respect to the goals identified in the test plan. A report summarizing the testing program and its results will be presented in the final FS Report.

\subsection{TASK 5: DETAILED ANALYSIS OF ALTERNATIVES}

\subsubsection{Subtask 5.1: Detailed Development of Remaining Alternatives}

The detailed development of the alternatives remaining after the screening described above will provide the information needed to complete the final evaluation and selection of the preferred alternative. Examples of development information include the following:

- The components of treatment and disposal technologies will be described to provide an understanding of the features and functions of the technologies.

- Special engineering considerations required to implement an alternative will be identified (e.g., treatability studies for in-situ treatment, benchscale testing for containment options, or pilot treatment facilities for on-site treatment).

- Proposed methods and costs, associated physical and legal issues, and compliance with ARARs will be discussed.

- Operation, maintenance, and monitoring requirements will be addressed (e.g., frequency, complexity, cost, and availability of labor and materials necessary for effective operations of the technologies).

- Alternatives involving off-site disposal that may impose special requirements for implementation will be addressed. The disposal needs and transportation plans, such as zoning clearances, local permits, and appropriate actions to comply with state and federal regulations, will be identified.

- Safety requirements for implementation of alternatives will address both off-site and on-site issues. Factors relative to the health and safety of site personnel, nearby populations, and the environment will be identified for both short-term and long-term operational periods. 


\subsubsection{Subtask 5.2: Evaluation of Alternatives against Regulatory Criteria}

Nine evaluation criteria, some of which are related to human health evaluation and risk, have been developed under the CERCLA program to address statutory requirements, as well as additional technical and policy considerations that have proven to be important to the process of selecting among remedial alternatives. The criteria are (1) overall protectiveness; (2) compliance with ARARs; (3) long-term effectiveness and permanence; (4) reduction of mobility, toxicity, or volume through treatment; (5) short-term effectiveness; (6) implementability; (7) cost; (8) state acceptance; and (9) community acceptance. These evaluation criteria will be use to conduct a detailed analysis and to select an appropriate remedial action for each operable unit. The results of the evaluation will be arrayed so that alternatives can be compared and key trade-offs identified.

The first two criteria - overall protectiveness and compliance with ARARs - are considered threshold determinations and must be met before a remedy can be selected. Evaluation of the overall protectiveness of an alternative will focus on how well it will achieve protection over time and reduce site risks and how it will become part of the sitewide remedy.

To satisfy the relevant NCP remedy-selection criteria, an assessment of the overall protectiveness and attainment of ARARs will be developed for each alternative. That assessment will be intended to determine how well the risks posed by each pathway associated with the operable unit are eliminated, reduced, or controlled through treatment, engineered controls, or institutional controls. A detailed analysis of the environmental effects will not be conducted if those effects are not within the scope of the alternative under consideration. Factors that will be considered include (1) effects on environmentally sensitive areas, (2) compliance with regulations, (3) short- and long-term effects, and (4) irreversible commitment of resources. Any known or potential environmental problems previously identified that are not addressed by the remedial alternative will be clearly described.

The evaluation of overall protectiveness criteria will address the effects (both longand short-term) of each alternative under consideration. Each alternative will be assessed with regard to how well it mitigates long-term exposure to any residual contamination and protects human health, both during and after completion of the remedial action. The assessment will describe the levels and characteristics of contaminants, potential exposure routes, and potentially affected populations. In general, the evaluation of each alternative will consider both the expected adverse effects and the beneficial effects, such as changes in the release of contaminants, resultant environmental conditions, improvements in the resources, and improvements in the biological environment.

The level of detail in this evaluation will depend on the degree of actual or potential damage to the environment providing the impetus for response. The level of detail must be adequate to compare the expected environmental benefits of different alternatives and to determine the effects of construction and operation. Because remedial activities may themselves have a wide range of environmental effects, findings will be presented in such a 
way as to permit comparison of the environmental effects of the different alternatives on specific resources (e.g., hydrological, geological, biological, land use).

The associated mitigative measures to be implemented will be analyzed for any alternative that appears to have significant inevitable or irreversible environmental effects. The analysis will take into consideration the technology to be used, the associated cost, and the mitigating effects.

To determine if an alternative satisfies ARAR criteria, the effects of federal, state, and local requirements, regulations, and other institutional considerations relative to the design, operation, and timing of each alternative will be evaluated. These results will be presented as part of the noncost criteria analysis in the final report. All ARARs and other standards to be considered will be identified.

The next five criteria are primary balancing criteria: long-term effectiveness and permanence; reduction of mobility, toxicity, or volume through the use of treatment; shortterm effectiveness; implementability; and cost. Risk will be an important factor in the analysis of effectiveness and permanence. The analysis will evaluate the residual risk at the site after response objectives have been met. The primary focus will be on effectiveness of the controls to manage risk posed by treatment residuals or any untreated wastes that may remain. The evaluation will also consider the potential impacts on human health and the environment if the remedy fails.

The last two criteria - state acceptance and community acceptance - are considered modifying criteria and do not include risk information. These criteria will be evaluated after public comments are received on the RI/FS reports and the proposed plan. The acceptance criteria will be addressed once a final decision is made and the record of decision (ROD) is being prepared.

The FS will satisfy the statutory requirements for the remedial actions that will be addressed in the ROD. Those provisions require that the remedial actions:

- Be protective of human health and the environment;

- Attain ARARs or provide grounds for invoking a waiver;

- Be cost-effective;

- Utilize permanent solutions and alternative treatment technologies, or resource recovery technologies, to the maximum extent practicable; and

- Satisfy the preference for treatment that reduces toxicity, mobility, or volume as a principal element (or provide an explanation as to why it does not).

Analyses of individual alternatives will include (1) a technical description that outlines the waste management strategy involved and identifies the key ARARs associated 
with each alternative and (2) a discussion that profiles the performance of the alternative with respect to each of the evaluation criteria. After the individual analyses are complete, the alternatives will be compared and contrasted relative to each of the evaluation criteria.

\subsection{TASK 6: COST ANALYSIS}

The cost analysis for each alternative and its component technologies will include consideration of site-specific factors identified from available information and determined during development of the alternative. Common sources for these cost estimates include vendors, estimates for similar projects, and standard costing guidance documents. This evaluation will include the following factors: cost estimation (estimation of capital costs and O\&M costs); present-worth analysis (calculation of annual costs and present worth on the basis of estimated costs); and summary of the costs of alternatives (summary of cost data, including total costs and distribution of costs over time).

\subsubsection{Subtask 6.1: Capital Costs}

Capital costs consist of direct (construction) and indirect (nonconstruction and overhead) costs. Direct costs include expenditures for equipment, labor, and installation materials. Capital costs that must be increased in future years as part of the remedial action alternatives will be identified and noted for the year in which they will occur. Indirect costs include expenditures for engineering, financial, and other services that are not part of actual installation activities but that are required to complete the installation of the technologies constituting the alternative. The following are examples of direct and indirect capital costs:

- Construction - materials, labor, and equipment;

- Equipment - remedial action and service equipment;

- Land and site development - purchase of land and preparation of the site;

- Buildings and services - utility connections, process and nonprocess buildings, purchased services;

- Disposal - transporting and disposing of wastes;

- Engineering - administration, construction supervision, design, treatability testing;

- License and permits - administrative costs to obtain building and operating permits;

- Start-up - activities to ensure that the systems are operational; and 
- Contingency fund - funds for unforeseen circumstances (e.g., weather, unexpected levels of contamination).

\subsubsection{Subtask 6.2: Operating and Maintenance Costs}

Operating and maintenance costs are postconstruction expenditures necessary to ensure the continued effectiveness of a remedial action. Typical O\&M costs include the following:

- Labor - wages, salaries, training, and overhead;

- Maintenance materials and labor - routine maintenance and equipment replacement;

- Auxiliary materials and energy - chemicals, electricity, water, sewer, fuel;

- Purchased services - sampling, laboratory;

- Insurance, taxes, and licenses - accident and liability insurance, real estate taxes, technology license fees; and

- Periodic site reviews - required at least every five years as long as wastes are present.

\subsubsection{Subtask 6.3: Present-Worth Analysis}

Present-worth analysis will be used to evaluate expenditures that occur over different time periods by discounting all future costs to the present. A discount rate of $3 \%$ before taxes and after inflation will be assumed in the present-worth analysis. This rate represents the average rate of return on private investment. Costs in each planning year will be estimated in constant dollars, representing the general purchasing power at the time of construction. The period of performance will not exceed 30 years for the purpose of detailed feasibility analysis.

\subsubsection{Subtask 6.4: Sensitivity Analysis}

After the present-worth analysis of each alternative is completed, sensitivity analyses will be used to evaluate each cost for the effects of variations in assumptions. This analysis will assess how variations in specific assumptions about the design, implementation, operation, discount rate, and effective life of an alternative can affect its estimated cost. The sensitivity analysis will be used to optimize the design of an alternative, particularly when design parameters are interdependent (e.g., treatment plant capacity for contaminated groundwater and the length of the period of performance). 


\subsubsection{Subtask 6.5: Cost Analysis Summary}

Data developed in the cost estimation and present-worth analysis will be used in a summary table to describe the alternative. To provide a common basis for comparison of costs, the following elements will be included in the summary: (1) total capital cost, (2) total cost of implementation, (3) present-worth costs, and (4) cash flow over the life of the alternative (including $O \& M$ costs and identification of future capital costs).

\subsection{TASK 7: SELECTION OF PREFERRED ALTERNATIVE}

To provide a basis for selection of a preferred alternative, the analysis of the alternatives will discuss the individual criteria assessment and include a comparative analysis to evaluate the relative performance of each alternative.

The individual alternative assessments will provide data on technology components, quantities of hazardous materials handled, time required for implementation, process sizing, implementation requirements, and assumptions. The significant ARARs for each alternative will be integrated into the discussion. A summary table will highlight the assessment of each alternative with respect to the nine evaluation criteria. The relative performances of the alternatives will be compared for each evaluation criterion. That analysis will include a discussion of the strengths and weaknesses of the alternatives (with respect to each criterion) and how reasonable variations of key uncertainties could change the expectations of relative performances. Substantive differences among alternatives will be identified.

The technology assessments and risk management judgments will be used to rank the alternatives and identify those alternatives projected to attain or exceed the requirements of the evaluation criteria. The comparative advantages and disadvantages of each alternative will be presented.

\subsection{TASK 8: REPORT PREPARATION}

An FS report will be prepared to document project activities carried out during implementation of the FS process for J-Field. The report will include an overview of the site background information and the compliance process and will summarize cleanup criteria derived from the baseline risk assessment. For each task, the report will outline the criteria used to perform the task and the rationale for the conclusions reached. Details of the FS report and other reporting requirements are discussed in Section 4 . 


\section{REPORT PREPARATION}

\subsection{DRAFT FEASIBILITY STUDY REPORT}

A draft FS report will be prepared by ANL to document all FS activities. Table 4.1 presents the general outline of the report; minor modifications may be made as appropriate. The contents of the report are discussed in the following sections. The current schedule for the preparation and submittal of all FS reports is provided in Appendix D of the RI Work Plan.

\subsubsection{Section 1: Introduction}

Section 1 will discuss the purpose and scope of the FS and the FS report. It will also provide an overview of the environmental compliance process for the project and describe the report organization.

\subsubsection{Section 2: Site Background}

Section 2 will present the site background relevant to the analysis of remedial action alternatives and management of the site, including (1) a brief description of the operational history and environmental setting of J-Field; (2) a summary of contamination, emphasizing key information from the RI report; (3) an overview of all environmental activities conducted at J-Field to date; and (4) a brief discussion of human health and environmental impacts that might occur in the absence of remedial action, using data from the baseline risk assessment (which includes an ecological risk assessment).

\subsubsection{Section 3: Remedial Action Objectives}

Section 3 will identify (1) the objectives of the remedial action at J-Field; (2) environmental standards, identified as ARARs; (3) the process for developing cleanup criteria; and (4) cleanup criteria for all contaminated media being remediated.

\subsubsection{Section 4: Identification and Screening of Technologies}

Section 4 will identify and screen potential response technologies for managing $J$ - Field and the criteria used for the evaluation.

\subsubsection{Section 5: Development and Screening of Preliminary Alternatives}

Section 5 will document the development and screening of preliminary alternatives and the criteria used for combining sets of technologies into alternatives. It will present the 
TABLE 4.1 Generalized Outline of FS Report

1 Introduction

1.1 Background

1.2 Purpose and Scope

1.3 Overview of the Environmental Compliance Process

1.4 Report Organization

2 Site Background

2.1 Site History

2.2 Site Description

2.2.1 Topography

2.2.2 Soils and Geology

2.2.3 Surface Water

2.2.4 Groundwater

2.2.5 Climate and Meteorology

2.2.6 Ecology

2.2.7 Land Use and Demography

2.3 Nature and Extent of Contamination

2.4 Environmental Activities at J-Field

2.4.1 Remedial Investigation

2.4.2 Baseline Risk Assessment

2.4.3 Interim Action at the Toxic Burning Pits

2.5 Summary of Site Risks

2.5.1 Human Health Risk Assessment

2.5.2 Ecological Risk Assessment

3 Remedial Action Objectives

3.1 Overall Remedial Action Objectives

3.2 Environmental Standards and Guidelines

3.3 General Process for Developing Cleanup Criteria

3.4 Cleanup Criteria

4 Identification and Screening of Technologies

4.1 Criteria for Identifying and Screening Technologies

4.2 Technology Identification and Screening

4.3 Potentially Applicable Technologies

5 Development and Screening of Preliminary Alternatives

5.1 Criteria for Developing Preliminary Alternatives

5.2 Identification of Preliminary Alternatives

5.3 Criteria for Screening Alternatives

5.4 Screening of Preliminary Alternatives

5.5 Screening Summary and Identification of Final Alternatives 
TABLE 4.1 (Cont.)

6 Detailed Analysis of Alternatives

6.1 Alternative 1

6.1.1 Overall Protection of Human Health and the

Environment

6.1.2 Compliance with ARARs

6.1.3 Long-Term Effectiveness

6.1.4 Reduction of Toxicity, Mobility, or Volume through

Treatment

6.1.5 Short-Term Effectiveness

6.1.6 Implementability

6.1.7 Cost

7 Comparative Analysis of Alternatives

7.1 Threshold Criteria

7.1.1 Overall Protection of Human Health and the Environment

7.1.2 Compliance with ARARs

7.2 Primary Balancing Criteria

7.2.1 Long-Term Effectiveness and Permanence

7.2.2 Reduction of Toxicity, Mobility, or Volume through

Treatment

7.2.3 Short-Term Effectiveness

7.2.4 Implementability

7.2.5 Cost

7.3 Comparative Summary

8 References

9 Agencies Contacted

objective of the alternative (e.g., source control or mitigation of contaminant migration), identify key features, describe each alternative, and summarize the evaluation of the alternative. This section will also include (1) associated control, treatment, and disposal requirements; (2) special engineering, safety, and other features that affect the feasibility of

the alternative; (3) operation, maintenance, and monitoring requirements; and (4) aspects of the contamination that the alternative will address.

\subsubsection{Section 6: Detailed Analysis of Alternatives}

Section 6 will present a detailed analysis of each alternative relative to the nine EPA evaluation criteria. The discussion of protectiveness and compliance with ARARs will focus on how well each alternative achieves protection over time and reduces risks identified for each operable unit. The technical discussion will focus on the effectiveness, implementability, and cost of each alternative. The discussion of modifying factors will present regulatory and community acceptance issues for each alternative and will address impacts of those issues on the selection of an alternative. The cost analysis will summarize the estimated costs for 
each alternative, review the main cost items, and discuss other important considerations in the cost analysis. The cost analysis will also include (1) costing methodology; (2) capital costs; (3) operation and maintenance costs; (4) present-worth analysis; (5) phasing of the work and its impact on cost, as appropriate; and (6) distribution of costs over time.

\subsubsection{Section 7: Comparative Analysis of Alternatives}

Section 7 will present a comparative analysis of the alternatives, describing the relative strengths and weaknesses of the alternatives with respect to each of the nine evaluation criteria. The effects of variations in key uncertainties on the relative performance of the alternatives will also be discussed. A preferred alternative will be selected and described in detail.

Tables and figures will be used to summarize important features of the alternatives. The advantages and disadvantages of each alternative will be listed for comparison. The preferred alternative and the rationale for its selection will be presented at the end of the section. The discussion will include, as appropriate, (1) a review of what will and will not be accomplished by implementation of the preferred alternative; (2) special engineering considerations and studies required during the final design stage; (3) operating, maintenance, and monitoring requirements; (4) off-site disposal requirements and transportation plans; (5) safety requirements for implementation; and (6) integration of the alternative into the site-wide remedy.

\subsection{OTHER REPORTS AND COMMUNICATIONS}

\subsubsection{Monthly Progress Reports}

Monthly reports will be submitted to the Directorate of Safety, Health, and Environment in part to obtain input and agreement on the technologies considered. The reports will contain information about the following items:

- Status of work and the progress to date,

- Percentage of work completed and the status of the schedule,

- Problems encountered and the corrective actions taken,

- The activities in progress,

- The activities planned for the next reporting period,

- Changes in key project personnel, 
- Budget information, and

- Projection of expenditures needed to complete the project.

These frequent communications will streamline the FS process and promote cost savings by providing technical reviewers with opportunities to comment early in the decisionmaking process - before a commitment is made to conduct in-depth study. Through these comments, the screening decisions, assembly of technologies into alternatives, and identification of data deficiencies will be developed with a broader scope of information.

\subsubsection{Responsiveness Summary}

The draft FS Report will be revised to incorporate comments received from the sponsor, the public, and regulatory agencies. A responsiveness summary will present the comments received and the actions taken to address the comments. 
4-6 


\section{REFERENCES}

ANL — see Argonne National Laboratory.

Argonne National Laboratory, 1993, EMFLUX Soil-Gas Investigations of J-Field Toxic Burning Pit and Prototype Building Areas, Aberdeen Proving Ground, Technical Update TU-1/ANL/APG/J-F/RI, Argonne, Ill., Oct.

Argonne National Laboratory, 1994, EMFLUX Soil-Gas Investigation of J-Field Toxic Burning Pits and Riot Control Pit Areas, Aberdeen Proving Ground, Technical Update TU-9/ANL/APG/J-F/RI, Argonne, Ill., May.

Benioff, P., 1992, memo to file, Argonne National Laboratory, Argonne, Ill., June 2.

Benioff, P., et al., 1995a, Remedial Investigation Work Plan for J-Field, Aberdeen Proving Ground, Maryland, ANL/EAD/TM-40, Argonne National Laboratory, Argonne, Ill., March.

Benioff, P., et al., 1995b, Remedial Investigation Sampling and Analysis Plan for J-Field, Aberdeen Proving Ground, Maryland, Volume 1: Field Sampling Plan, ANL/EAD/TM-38, Vol. 1, Argonne National Laboratory, Argonne, Ill., March.

Biang, C., et al., 1995, Work Plan for Focused Feasibility Study of the Toxic Burning Pits Area at J-Field, Aberdeen Proving Ground, Maryland, ANL/EAD/TM-39, Argonne National Laboratory, Argonne, Ill., March.

COE - see U.S. Army Corps of Engineers.

EPA - see U.S. Environmental Protection Agency.

Hlohowskyj, I., et al., 1995, Work Plan for Conducting an Ecological Risk Assessment at J-Field, Aberdeen Proving Ground, Maryland, ANL/EAD/TM-45, Argonne National Laboratory, Argonne, Ill., March.

Hughes, W.B., 1992, Letter with attachment from Hughes (U.S. Geological Survey, Towson, Md.) to J. Wrobel (U.S. Army, Aberdeen Proving Ground, Md.), June 19.

Hughes, W.B., 1993, Hydrogeology and Soil-Gas at J-Field, Aberdeen Proving Ground, Maryland, U.S. Geological Survey, Water Resources Investigations Report 92-4087, prepared in cooperation with the U.S. Army, Aberdeen Proving Ground Support Activity, Environmental Management Division, Towson, Md.

ICF-Kaiser Engineers, 1991, Baseline Risk Assessment for Eight Selected Study Areas at Aberdeen Proving Ground, Task Order 11, Jan.

ICF-Kaiser Engineers, 1993, Risk and Biological Impact Assessment at U.S. Army Aberdeen Proving Ground, Maryland, Technical Plan, Task Order 4, Vol. 1, March. 
ICF-Kaiser Engineers, 1994, Comparison of Chemical Concentrations of Selected Sites at J-Field with Risk-Based Concentrations, draft report, submitted to U.S. Army Environmental Center, Aberdeen Proving Ground Installation Restoration Risk Assessment Support, Feb.

Mazelon, M., 1993, Letter from Mazelon (Chief Engineer, Roy F. Weston, Inc., Aberdeen Proving Ground, Md.) to R. Rizzieri (U.S. Army Corps of Engineers, Aberdeen Proving Ground, Md.), Feb. 26.

Nemeth, G., 1989, RCRA Facility Assessment, Edgewood Area, Aberdeen Proving Ground, $M D, 39-26-0490-90$, U.S. Army Environmental Hygiene Agency, Waste Disposal Engineering Division, Aberdeen Proving Ground, Md., Nov.

Prasad, S., et al., 1995, Remedial Investigation Sampling and Analysis Plan for J-Field, Aberdeen Proving Ground, Maryland, Volume 2: Quality Assurance Project Plan, ANL/EAD/TM-38, Vol. 2, Argonne National Laboratory, Argonne, Ill., March.

Princeton Aqua Science, 1984, Munitions Disposal Study, prepared for Department of the Army, Directorate of Engineering and Housing, Environmental Management Office, Aberdeen Proving Ground, Md.

Sonntag, W., 1991, Sampling and Analysis Plan for the Investigation of Ground-Water Contamination at J-Field, Aberdeen Proving Ground, Maryland, draft report, U.S. Geological Survey, Reston, Va.

U.S. Army, 1965, aerial photograph of Edgewood Area, roll no. G\&O 85047, frame nos. 8-1 to 8-2 and 9-1 to 9-4, Environmental Hygiene Agency, Aberdeen Proving Ground, Md.

U.S. Army Corps of Engineers, 1923, "Gunpowder Neck, Maryland, Grid Zone A," Terrain Map 26547531/46, War Department, U.S. Army, Washington, D.C.

U.S. Environmental Protection Agency, 1986, Quality Criteria for Water 1986, EPA 440/5-86/001, Office of Water Regulation and Standards, U.S. Environmental Protection Agency, Washington, D.C., May.

U.S. Environmental Protection Agency, 1988, Guidance for Conducting Remedial Investigations and Feasibility Studies under CERCLA, Interim Final, EPA/540/G-89/004, Office of Emergency and Remedial Response, Washington, D.C., Oct.

U.S. Environmental Protection Agency, 1989a, Risk Assessment Guidance for Superfund (Part A) Volume II: Environmental Evaluation Manual, Interim Final, EPA/540/1-89/001A (OSWER Directive 9285.7-01), Office of Emergency and Remedial Response, Washington, D.C., March.

U.S. Environmental Protection Agency, 1989b, Risk Assessment Guidance for Superfund, Volume I: Human Health Evaluation Manual (Part A), Interim Final, EPA540/1-89/002, Office of Emergency and Remedial Response, Washington, D.C., Dec. 
U.S. Environmental Protection Agency, 1990, National Oil and Hazardous Substances Pollution Contingency Plan; Final Rule (40 CFR Part 300), Federal Register 55(46):61546176, Feb. 21.

U.S. Environmental Protection Agency, 1991a, Drinking Water Regulations and Health Advisories, Office of Water, Washington, D.C.

U.S. Environmental Protection Agency, 1991b, Risk Assessment Guidance for Superfund: Volume I: Human Health Evaluation Manual (Part B, Development of Risk-Based Preliminary Remediation Goals), Interim (OSWER Directive 9285.7-01B), Office of Emergency and Remedial Response, Washington, D.C., Dec.

U.S. Environmental Protection Agency, 1992a, unpublished data.

U.S. Environmental Protection Agency, 1992b, Drinking Water Regulations and Health Advisories, Office of Water, Washington, D.C., April.

U.S. Environmental Protection Agency, 1992c, Framework for Ecological Risk Assessment, EPA/630/R-92/001, Risk Assessment Forum, Washington, D.C.

USGS - see U.S. Geological Survey.

U.S. Geological Survey, 1991, Phase II Workplan and Field Sampling Plan Update for the Remedial Investigation at J-Field Aberdeen Proving Ground, Maryland, prepared by the USGS, Water Resources Division, Towson, Md., for the U.S. Army, Aberdeen Proving Ground Support Activity, Environmental Management Division, Aberdeen, Md.

U.S. Geological Survey, 1992, unpublished data.

Weston, Roy F., 1992, Characterization and Interim Remediation of J-Field at Edgewood Area Aberdeen Proving Ground, Maryland, Draft Report, Roy F. Weston, Inc., for U.S. Army Corps of Engineers, Baltimore District, Feb.

Wrobel, J., 1994, personal communication from Wrobel (Directorate of Safety, Health, and Environment, U.S. Army, Aberdeen Proving Ground, Md.), to J. Quinn (Environmental Assessment Division, Argonne National Laboratory, Argonne, Ill.), Aug. 23. 
5-4 


\section{LIST OF PREPARERS}

This Feasibility Study Work Plan was prepared for the U.S. Army Directorate of Safety, Health, and Environment by the Environmental Assessment Division of ANL. The following ANL staff have contributed to the preparation of this work plan.

\begin{tabular}{|c|c|c|}
\hline Name & Education/Experience & Contribution \\
\hline Louis Martino & $\begin{array}{l}\text { M.S., environmental toxicology; } \\
15 \text { years experience in environmental } \\
\text { assessment; J-Field project manager. }\end{array}$ & $\begin{array}{l}\text { Section } 1 \text { Introduction } \\
\text { Section } 2 \text { Site Backgound }\end{array}$ \\
\hline Paul Benioff & $\begin{array}{l}\text { Ph.D., nuclear chemistry; } 17 \text { years } \\
\text { experience in theoretical chemistry; } \\
16 \text { years experience in environmental } \\
\text { assessment; lead author. }\end{array}$ & $\begin{array}{ll}\text { Section } 2 & \text { Site Background } \\
\text { Section } 3 & \text { Feasibility } \\
\text { Study Tasks }\end{array}$ \\
\hline Carole Biang & $\begin{array}{l}\text { B.S., chemical engineering; } 15 \text { years } \\
\text { experience in management and } \\
\text { remediation of hazardous waste sites; } \\
\text { environmental assessment. }\end{array}$ & $\begin{array}{l}\text { Section } 1 \text { Introduction } \\
\text { Section } 3 \text { Feasibility } \\
\text { Study Tasks } \\
\text { Section } 4 \text { Report } \\
\text { Preparation }\end{array}$ \\
\hline Melissa Goyette & $\begin{array}{l}\text { M.S., environmental engineering; } \\
7 \text { years experience in environmental } \\
\text { research and assessment. }\end{array}$ & $\begin{array}{l}\text { Section } 3 \text { Feasibility } \\
\text { Study Tasks }\end{array}$ \\
\hline $\begin{array}{l}\text { Rebecca } \\
\text { Haffenden }\end{array}$ & $\begin{array}{l}\text { J.D., } 5 \text { years experience in } \\
\text { environmental law, specializing in } \\
\text { RCRA and CERCLA; } 10 \text { years } \\
\text { experience in energy law. }\end{array}$ & $\begin{array}{l}\text { Section } 2 \text { Site Background } \\
\text { Appendix A Applicable or } \\
\text { Relevant and Appropriate } \\
\text { Requirements }\end{array}$ \\
\hline Terri Patton & $\begin{array}{l}\text { M.S., geology; } 6 \text { years experience in } \\
\text { radiochemical analysis; } 5 \text { years } \\
\text { experience in environmental } \\
\text { assessment. }\end{array}$ & $\begin{array}{ll}\text { Section } 2 & \text { Site Background } \\
\text { Section } 4 & \text { Report } \\
\text { Preparation } & \end{array}$ \\
\hline Cheong-Yip Yuen & $\begin{array}{l}\text { Ph.D., geology (hydrogeology and } \\
\text { environmental geology); } 6 \text { years } \\
\text { experience in hydrogeological } \\
\text { analysis; } 12 \text { years experience in } \\
\text { process geomorphology. }\end{array}$ & $\begin{array}{l}\text { Appendix B Indentification } \\
\text { of Potential Areas of Concern } \\
\text { at J-Field }\end{array}$ \\
\hline
\end{tabular}




\section{6-2}


A-1

APPENDIX A:

APPLICABLE OR RELEVANT AND APPROPRIATE REQUIREMENTS 
A-2 
TABLE A.1 State Regulations and To-Be-Considereds for J-Field

\begin{tabular}{|c|c|c|}
\hline Potential ARAR & Medium & Requirements \\
\hline $\begin{array}{l}\text { COMAR 14.19, Chesapeake } \\
\text { Bay Critical Area Commission } \\
\text { - Development in the } \\
\text { Critical Area Resulting from } \\
\text { State and Local Agency } \\
\text { Programs }\end{array}$ & $\begin{array}{l}\text { Water, } \\
\text { sediment, } \\
\text { soil }\end{array}$ & $\begin{array}{l}\text { Protection of the bay, and criteria for any } \\
\text { development in the bay area. }\end{array}$ \\
\hline $\begin{array}{l}\text { Maryland Nonpoint Source } \\
\text { Pollution Control Laws, } \\
\text { Annotated Code of Maryland } \\
4.1 \text { and } 4.2\end{array}$ & $\begin{array}{l}\text { Water- } \\
\text { sheds }\end{array}$ & $\begin{array}{l}\text { Construction includes soil movement, grading, } \\
\text { transporting, or otherwise disturbing land. } \\
\text { Any such action undertaken by a federal unit, } \\
\text { including a sediment control plan, must be } \\
\text { reviewed and approved by the Department. }\end{array}$ \\
\hline $\begin{array}{l}\text { COMAR } 26.09 .01 \text { and } \\
26.09 .02\end{array}$ & $\begin{array}{l}\text { Sediment, } \\
\text { storm } \\
\text { water }\end{array}$ & $\begin{array}{l}\text { Protection of areas for erosion and sediment } \\
\text { control, along with maintaining pre- } \\
\text { development runoff characteristics and } \\
\text { reducing stream channel erosion, pollution, } \\
\text { siltation and sedimentation, and local flooding. }\end{array}$ \\
\hline COMAR 8.05 & Wetlands & $\begin{array}{l}\text { It is prohibited to fill, place, dump, or } \\
\text { discharge any dirt, trash, or polluting } \\
\text { substances; to drain, dredge, or remove soil; to } \\
\text { destroy natural vegetation; or to substantially } \\
\text { alter existing patterns of tidal flow without a } \\
\text { permit. }\end{array}$ \\
\hline
\end{tabular}

Preliminary

Determination

Remarks

Potentially applicable

Potentially applicable

Potentially applicable

Potentially relevant and appropriate
Applies to Chesapeake Bay only. The bay borders the site to the south and may receive discharge from groundwater aquifers.

Potential impacts will depend on the remedial actions.

Any excavation of soils may require compliance with this law.

Any remedial action must address these regulations.

Any remedial action that would disturb wetlands may require consultation with the Water Resource Administration. 
TABLE A.1 (Cont.)

\begin{tabular}{|c|c|c|c|c|c|}
\hline Potential ARAR & Medium & Requ & ents & $\begin{array}{c}\text { Preliminary } \\
\text { Determination }\end{array}$ & Remarks \\
\hline COMAR 26.04.01 & $\begin{array}{l}\text { Ground- } \\
\text { water }\end{array}$ & $\begin{array}{l}\text { For community water } \\
\text { MCLs for metals, chlo } \\
\text { chlorophenoxys, total } \\
\text { organic chemicals, an } \\
\text { Contaminant } \\
\text { Arsenic } \\
\text { Benzene } \\
\text { Carbon tetrachloride } \\
\text { Cyanide } \\
\text { 11DCE } \\
\text { Lead } \\
\text { Nitrate } \\
\text { Selenium } \\
\text { 111TCE } \\
\text { TCLEE } \\
\text { TRCLE } \\
\text { Gross alpha } \\
\text { Gross beta from } \\
\text { manmade radio- } \\
\text { nuclides }\end{array}$ & $\begin{array}{l}\text { ems, pertinent } \\
\text { ted hydrocarbons, } \\
\text { alomethanes, volatile } \\
\text { lioactivity include: } \\
\text { MCL (mg/L) } \\
0.05 \\
0.005 \\
0.005 \\
0.2 \\
0.007 \\
0.05 \\
10.0 \\
0.01 \\
0.2 \\
0.005 \\
0.005 \\
15 \mathrm{pCi} / \mathrm{L} \\
50 \mathrm{pCi} / \mathrm{L} \text { if } \\
\text { strontium- } 90 \\
\text { is }<8 \mathrm{pCi} / \mathrm{L}\end{array}$ & $\begin{array}{l}\text { Potentially } \\
\text { relevant and } \\
\text { appropriate }\end{array}$ & $\begin{array}{l}\text { The aquifers underlying the site } \\
\text { are Type I Aquifers as defined } \\
\text { by COMAR } 26.08 .02 .09 \text {. These } \\
\text { regulations for Type I aquifers } \\
\text { state that disposal of wastes } \\
\text { cannot cause the natural } \\
\text { groundwater quality to exceed } \\
\text { mandatory or recommended } \\
\text { standards for drinking water as } \\
\text { established by the MDE in } \\
\text { COMAR } 26.04 .01 \text {. MCLs are } \\
\text { applicable at the tap, but may } \\
\text { be relevant and appropriate for } \\
\text { aquifer remedial goals. }\end{array}$ \\
\hline
\end{tabular}




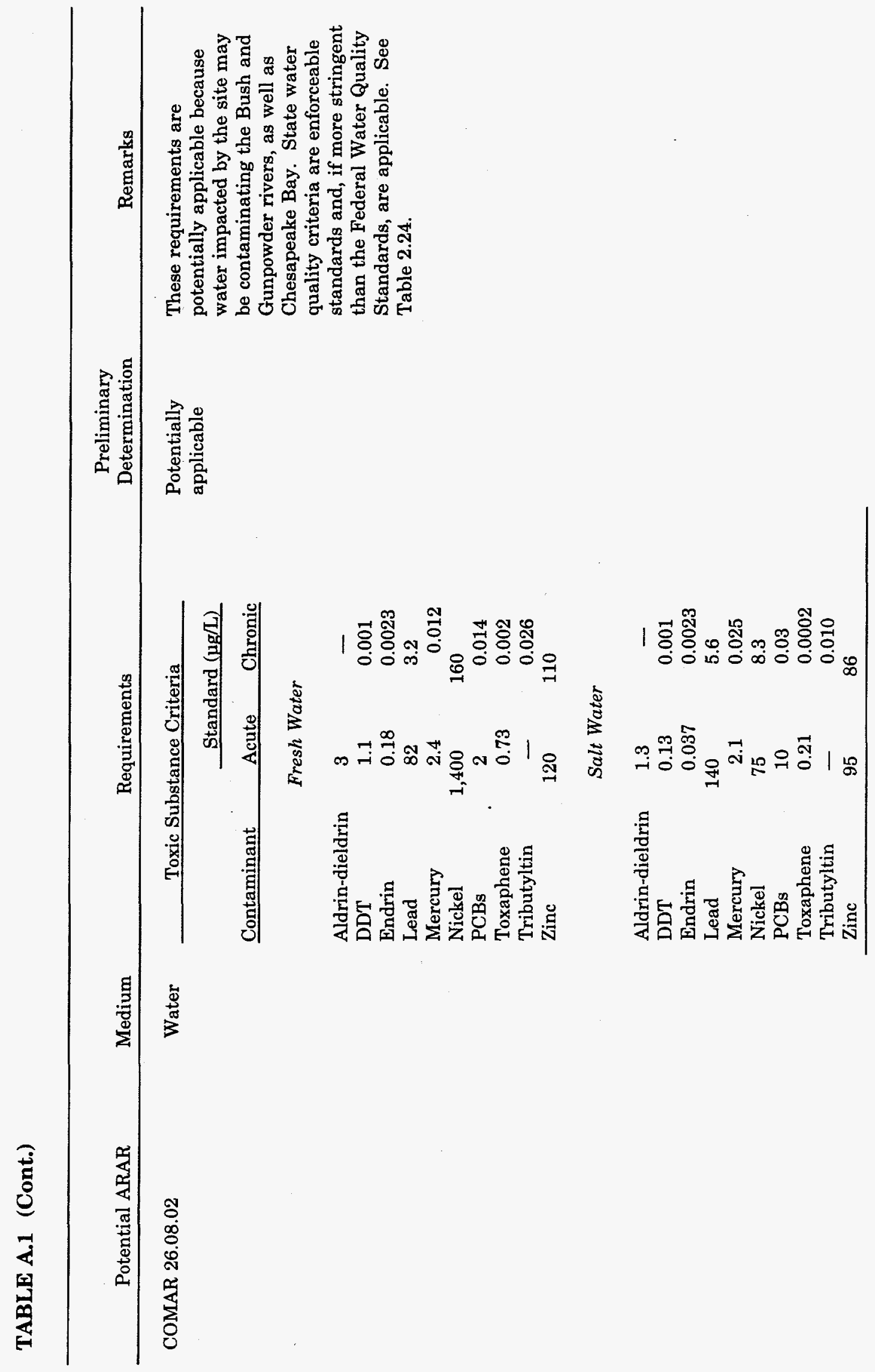


TABLE A.1 (Cont.)

\begin{tabular}{|c|c|c|c|}
\hline Potential ARAR & Medium & & Requirements \\
\hline & & \multicolumn{2}{|c|}{$\begin{array}{l}\text { Water Quality Criteria Specific to Designated } \\
\text { Use Classes I and II }\end{array}$} \\
\hline & & Parameter & Criteria \\
\hline & & $\begin{array}{l}\text { Dissolved oxygen } \\
\text { Temperature } \\
\text { pH } \\
\text { Turbidity }\end{array}$ & $\begin{array}{l}>5 \mathrm{mg} / \mathrm{L} \\
\leq 90^{\circ} \mathrm{F} \text { (or the ambient } \\
\text { temperature of the surface } \\
\text { water, whichever is greater) } \\
6.5-8.5 \\
\leq 150 \\
\leq 50 \text { (monthly average) }\end{array}$ \\
\hline
\end{tabular}

Prohibited toxic discharges:

1. The discharge of any pollutant in toxic amounts including

a. substances that accumulate to toxic amounts during the expected life of organisms in the surface water, or

b. substances that produce deleterious behavioral effects on the organisms.

2. The discharge of any radiological, chemical, or biological warfare agent.

3. The discharge of any waters in excess of $10,000 \mathrm{gal} / \mathrm{d}$ or the discharge of waste or wastewater regardless of volume without a discharge permit. Permit limits and technical requirements apply to the construction and operation of any facility for the discharge of wastes or wastewaters into the waters of the state.

Preliminary

Determination

Remarks

Potentially

applicable

"Discharge" is defined as the addition, introduction, spilling, or emitting of any pollutant to waters of the state; or, the placing of a pollutant in a location where it is likely to pollute the site. Pollutants have been and are continuing to be discharged to the two estuaries and to Chesapeake Bay; thus, the requirements are potentially applicable. If a new wastewater treatment plant is constructed at J-Field, permit limts and technical requirements would have to be met. If pumpand-treat wastewaters are taken to the O-Field treatment plant, permit modification may be necessary. 
TABLE A.1 (Cont.)

\begin{tabular}{|c|c|c|c|c|}
\hline Potential ARAR & Medium & Requirements & $\begin{array}{c}\text { Preliminary } \\
\text { Determination }\end{array}$ & Remarks \\
\hline $\begin{array}{l}\text { COMAR 26.11.01, 26.11.03, and } \\
26.11 .06\end{array}$ & Air & $\begin{array}{l}\text { State-adapted national ambient air quality } \\
\text { standards and guidelines must be met for } \\
\text { PM-10 24-h, sulfur dioxide, nitrogen dioxide, } \\
\text { and lead. For particulate matter from } \\
\text { materials handling and construction, } \\
\text { reasonable precautions must be taken to } \\
\text { prevent matter from becoming airborne; e.g., } \\
\text { use of water or chemicals for dust control } \\
\text { during demolition. In addition, the treatment } \\
\text { of waste containing VOCs may not be } \\
\text { performed in a manner that results in } \\
\text { evaporation of VOCs to the atmosphere } \\
\text { greater than } 20 \mathrm{lb} / \mathrm{d} \text {. }\end{array}$ & $\begin{array}{l}\text { Potentially } \\
\text { relevant and } \\
\text { appropriate }\end{array}$ & $\begin{array}{l}\text { In the past, the site has been a } \\
\text { source of emissions. Potential } \\
\text { emissions may occur in the } \\
\text { marshes where CWAs and UXO } \\
\text { may exist and during emergency } \\
\text { use of the TBP and WPP. The } \\
\text { site is an unconfined source in } \\
\text { what is termed an Area III (per } \\
26.11 .01 \text {, p. 139). Particulate } \\
\text { matter must be controlled } \\
\text { during demolition or other } \\
\text { earth-moving activities. The } \\
\text { treatment of VOC-contaminated } \\
\text { soils and/or pump-and-treat } \\
\text { operations may be sources of } \\
\text { VOC emissions. }\end{array}$ \\
\hline
\end{tabular}

COMAR 26.11.15

COMAR 26.11.21

COMAR 26.04.04
General requirements for the discharge of toxic air pollutants to the atmosphere. Also outlines procedures for requesting permits for discharge.

All worker protection requirements must be followed for asbestos contamination.

Guidelines and standards require conditions and control features for asbestos abatement.

Also, procedures are outlined for handling and disposing of asbestos.
General requirements for installing, constructing, operating, and abandoning wells.
Potentially applicable

Potentially applicable

Potentially applicable
Potentially applicable to any emissions resulting from remedial actions, such as in-situ treatment and pump-and-treat actions. In addition, CWAs are listed as Class I Toxic Air Pollutants.

During the remedial action, should the PB contain asbestos, the standards and guidelines will have to be met and followed. Also, asbestos may have been disposed of in one or more pits.

Potentially applicable to the construction of wells during remedial action. 
TABLE A.1 (Cont.)

\begin{tabular}{|c|c|c|c|c|}
\hline Potential ARAR & Medium & Requirements & $\begin{array}{c}\text { Preliminary } \\
\text { Determination }\end{array}$ & Remarks \\
\hline COMAR 26.04.07 & Solid waste & $\begin{array}{l}\text { General regulations for disposing of solid } \\
\text { waste in a land-based unit, including } \\
\text { procedures for closure and postclosure. Also, } \\
\text { sites that act as a transfer station or } \\
\text { processing facility for on-site disposal must } \\
\text { follow these regulations. }\end{array}$ & $\begin{array}{l}\text { Potentially } \\
\text { applicable }\end{array}$ & $\begin{array}{l}\text { Should the remedial action } \\
\text { involve landfilling, transferring, } \\
\text { and/or processing the waste (as } \\
\text { defined by COMAR } 26.04 .07 .02 \text { ), } \\
\text { these regulations must be } \\
\text { followed. }\end{array}$ \\
\hline COMAR 26.13.01.05 & $\begin{array}{l}\text { Hazardous } \\
\text { waste }\end{array}$ & $\begin{array}{l}\text { These regulations identify and list hazardous } \\
\text { waste, define hazardous waste, and present } \\
\text { standards applicable to generators and trans- } \\
\text { porters of hazardous waste. Also, standards } \\
\text { are presented for owners and operators of } \\
\text { hazardous waste treatment/storage/disposal } \\
\text { facilities. Standards include groundwater } \\
\text { protection and prohibition of OB/OD of waste } \\
\text { explosives containing EPA hazardous wastes } \\
\text { F020, 8021, F022, F023, F026, and F027. } \\
\text { Maryland-listed acute hazardous wastes } \\
\text { include the chemicals GA (tabun), GB (sarin), } \\
\text { GD (soman), VX, L (lewisite), DM (adamsite), } \\
\text { HD (sulfur mustard), T, waste military CWAs } \\
\text { having any of these substances } \\
\text { as their active or principal ingredient, or } \\
\text { mixtures of any of these substances and any } \\
\text { characteristic or listed hazardous waste. } \\
\text { Maryland-listed hazardous waste from specific } \\
\text { sources includes residues from the treatment } \\
\text { of the above-listed wastes, except when } \\
\text { treated at the following: } \\
\text { - U.S. Army APG/U.S. Army Chemical } \\
\text { Research Development and Engineering } \\
\text { Center; }\end{array}$ & $\begin{array}{l}\text { Potentially } \\
\text { applicable }\end{array}$ & $\begin{array}{l}\text { These requirements are applic- } \\
\text { able to any removal actions if } \\
\text { the waste at the site meets the } \\
\text { prerequisites for definition as } \\
\text { characteristic or listed } \\
\text { hazardous waste. Also, these } \\
\text { requirements apply to } \\
\text { groundwater contamination and } \\
\text { dispersal of hazardous air } \\
\text { pollutants. }\end{array}$ \\
\hline
\end{tabular}




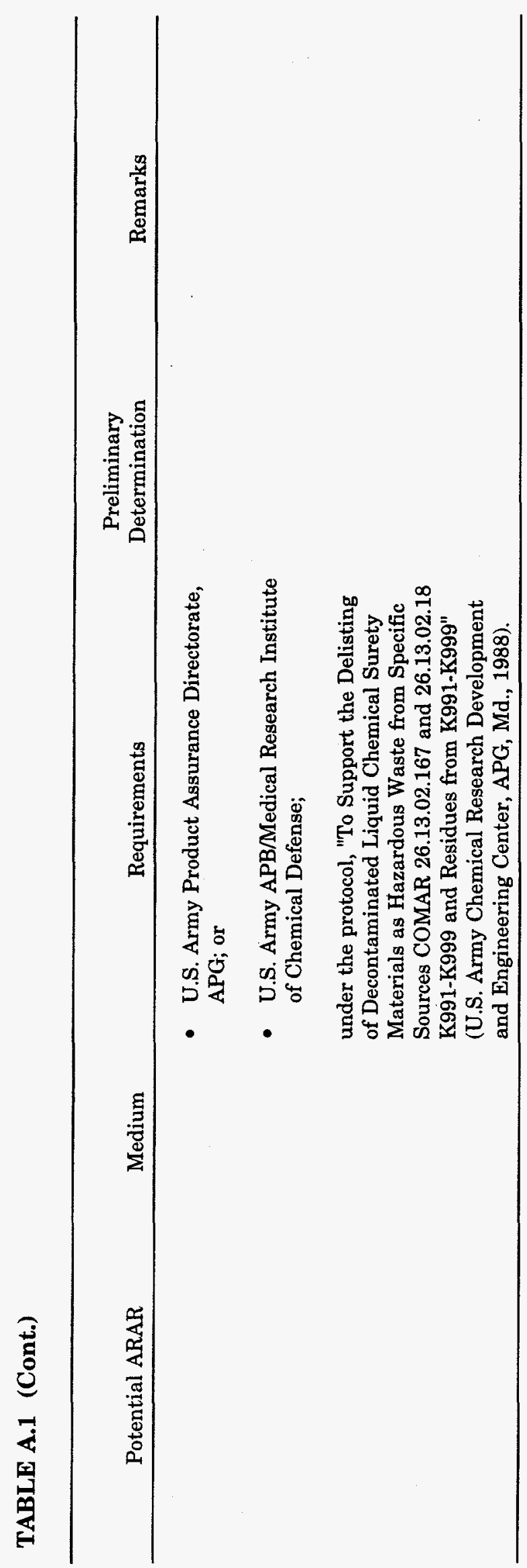


TABLE A.2 Federal Regulations and To-Be-Considereds for J-Field - Potential Contaminant-Specific Requirements

\begin{tabular}{|c|c|c|c|c|c|}
\hline Potential ARARs & Contaminant & Medium & Requirements & $\begin{array}{c}\text { Preliminary } \\
\text { Determination }\end{array}$ & Remarks \\
\hline \multirow[t]{2}{*}{$\begin{array}{l}\text { Clean Air Act, as amended } \\
\text { (42 USC } 7401-7642 \text { ); } \\
\text { National Primary and } \\
\text { Secondary Ambient Air } \\
\text { Quality Standards } \\
\text { (40 CFR Part 50) }\end{array}$} & $\begin{array}{l}\text { Particulate } \\
\text { matter }\end{array}$ & Air & $\begin{array}{l}\text { For a major stationary source } \\
\text { [see } 40 \mathrm{CFR} 52.2(\mathrm{~b})(1)(\mathrm{i})(\mathrm{a}) \text { ] that } \\
\text { emits }>250 \text { tons/yr of any } \\
\text { regulated pollutant or } \\
>100 \text { tons/yr of a regulated } \\
\text { pollutant for which the area is } \\
\text { designated as nonattainment, } \\
\text { PM-10 should not exceed a } 24-\mathrm{h} \\
\text { average concentration of } \\
150 \mu \mathrm{g} / \mathrm{m}^{3} \text { or an annual arith- } \\
\text { metic mean of } 50 \mu \mathrm{g} / \mathrm{m}^{3} \text {. }\end{array}$ & $\begin{array}{l}\text { Potentially } \\
\text { relevant and } \\
\text { appropriate }\end{array}$ & $\begin{array}{l}\text { These requirements do not apply } \\
\text { directly to source-specific } \\
\text { emissions; rather, they are } \\
\text { national limitations on ambient } \\
\text { concentrations. However, they will } \\
\text { be addressed in controlling } \\
\text { particulate emissions that could } \\
\text { result from implementation of a } \\
\text { remedial action. }\end{array}$ \\
\hline & Lead & Air & $\begin{array}{l}\text { As for the above conditions, the } \\
\text { standard for lead and its } \\
\text { compounds, as elemental lead, is } \\
1.5 \mu \mathrm{g} / \mathrm{m}^{3} \text { maximum arithmetic } \\
\text { mean averaged over one calendar } \\
\text { quarter. }\end{array}$ & $\begin{array}{l}\text { Potentially } \\
\text { relevant and } \\
\text { appropriate }\end{array}$ & $\begin{array}{l}\text { These requirements do not apply } \\
\text { directly to source-specific } \\
\text { emissions; rather, they are } \\
\text { national limitations on ambient } \\
\text { concentrations. However, they will } \\
\text { be addressed in controlling lead } \\
\text { emissions that could result from } \\
\text { implementation of a remedial } \\
\text { action. }\end{array}$ \\
\hline $\begin{array}{l}\text { OSHA Standards, } \\
\text { Occupational Health and } \\
\text { Environmental Control } \\
\text { [29 CFR } 1910.95(\mathrm{~g})]\end{array}$ & Noise & Air & $\begin{array}{l}\text { The permissible occupational } \\
\text { exposure level for noise is } \\
90 \mathrm{dBA} \text { (slow response) for an } \\
8 \text {-h day; with decreasing times of } \\
\text { exposure, the levels increase to } \\
115 \text { dBA per 15-min day. }\end{array}$ & $\begin{array}{l}\text { Potentially } \\
\text { applicable }\end{array}$ & $\begin{array}{l}\text { These requirements are part of an } \\
\text { employee protection law (rather } \\
\text { than an environmental law) with } \\
\text { which all CERCLA response } \\
\text { actions should comply. Because } \\
\text { this compliance is directly } \\
\text { required, as promulgated in the } \\
\text { NCP, these requirements are not } \\
\text { subject to evaluation for } \\
\text { attainment or waiver as part of the } \\
\text { ARAR process. However, they } \\
\text { constitute requirements for worker } \\
\text { protection with which any remedial } \\
\text { action will comply. }\end{array}$ \\
\hline
\end{tabular}


TABLE A.2 (Cont.)

\begin{tabular}{|c|c|c|c|c|c|}
\hline Potential ARARs & Contaminant & Medium & Requirements & $\begin{array}{c}\text { Preliminary } \\
\text { Determination }\end{array}$ & Remarks \\
\hline $\begin{array}{l}\text { TSCA, as amended (15 } \\
\text { USC 2607-2629, PL 94-469, } \\
\text { et seq.); Polychlorinated Bi- } \\
\text { phenyls Manufacturing, } \\
\text { Processing, Distribution in } \\
\text { Commerce, and Use } \\
\text { Prohibitions [40 CFR } \\
\text { Part } 761(\mathrm{~g}) \text { ] }\end{array}$ & $\mathrm{PCBs}$ & Soil & $\begin{array}{l}\text { For spills of materials } \\
\text { contaminated with }>50 \text { ppm } \\
\text { PCBs in unrestricted- access } \\
\text { areas (e.g., residential areas), } \\
\text { soil within the spill area must be } \\
\text { excavated and backfilled with } \\
\text { soil containing < } 1 \text { ppm PCBs. } \\
\text { Contaminated soil may be } \\
\text { decontaminated to } 10 \text { ppm by } \\
\text { weight by excavating a minimum } \\
\text { of } 10 \text { in. and backfilling with soil } \\
\text { containing <1 ppm PCBs. For } \\
\text { spills at outdoor electrical } \\
\text { substations, the soil must be } \\
\text { cleaned to } 25 \text { ppm by weight (as } \\
\text { for other restricted-access areas) } \\
\text { or to } 50 \text { ppm by weight with } \\
\text { posting of a visible notice. }\end{array}$ & $\begin{array}{l}\text { Potentially } \\
\text { relevant and } \\
\text { appropriate }\end{array}$ & $\begin{array}{l}\text { Any such spills at the site would } \\
\text { have preceded the effective date of } \\
\text { this requirement; hence, it is not } \\
\text { applicable. However, it may be } \\
\text { considered relevant and appro- } \\
\text { priate to the remedial action. }\end{array}$ \\
\hline $\begin{array}{l}\text { Safe Drinking Water Act } \\
\text { (42 USC 300G, PL 93-523); } \\
\text { National Primary Drinking } \\
\text { Water Regulations } \\
\text { [40 CFR Part 141(b)(g)]; } \\
\text { National Secondary } \\
\text { Drinking Water Regula- } \\
\text { tions (40 CFR Part 143) }\end{array}$ & Any & Water & $\begin{array}{l}\text { See } 40 \text { CFR Parts } 141 \text { and } 143 \\
\text { for MCLs and secondary MCLs } \\
\text { for drinking water delivered } \\
\text { directly to the ultimate user of a } \\
\text { public water system. }\end{array}$ & $\begin{array}{l}\text { Potentially } \\
\text { relevant and } \\
\text { appropriate }\end{array}$ & $\begin{array}{l}\text { These requirements are potentially } \\
\text { relevant and appropriate because } \\
\text { contaminated aquifers under the } \\
\text { site have potential use for drinking } \\
\text { water. Also, proposed rules (54 FR } \\
\text { Part } 97 \text { and } 53 \text { FR Part 160) for } \\
\text { MCLs and secondary MCLs should } \\
\text { be considered (although levels set } \\
\text { at } 0 \text { do not apply at CERCLA } \\
\text { action sites), and are potentially } \\
\text { relevant and appropriate } \\
\text { regulations when promulgated. }\end{array}$ \\
\hline
\end{tabular}


TABLE A.2 (Cont.)

\begin{tabular}{|c|c|c|c|c|c|}
\hline Potential ARARs & Contaminant & Medium & Requirements & $\begin{array}{c}\text { Preliminary } \\
\text { Determination }\end{array}$ & Remarks \\
\hline $\begin{array}{l}\text { Federal Water Pollution } \\
\text { Control Act, Clean Water } \\
\text { Act (33 USC 1251-1376); } \\
\text { Water Quality Criteria } \\
\text { (40 CFR Part 122) }\end{array}$ & Any & Water & $\begin{array}{l}\text { Concentration limits for a long } \\
\text { list of contaminants in surface } \\
\text { water are specified for the } \\
\text { protection of human health and } \\
\text { aquatic life. See Table } 2.24 \text {. }\end{array}$ & To be considered & $\begin{array}{l}\text { Federal water quality criteria are } \\
\text { nonenforceable guidelines used by } \\
\text { states and the federal government } \\
\text { to set water quality standards for } \\
\text { surface water; however, they may } \\
\text { be relevant and appropriate if the } \\
\text { water concerned is a public water } \\
\text { supply or if fishing is also included } \\
\text { in the state's designated use of the } \\
\text { waters concerned. If a state has } \\
\text { promulgated a numerical water } \\
\text { quality standard for a given } \\
\text { contaminant, the state standard } \\
\text { rather than the federal water } \\
\text { quality criteria would be relevant } \\
\text { and appropriate. }\end{array}$ \\
\hline $\begin{array}{l}\text { Solid Waste Disposal Act, } \\
\text { as amended ( } 42 \text { USC } 6901 \text {, } \\
\text { et seq.); Solid Wastes } \\
{[40 \text { CFR } 261(\mathrm{c})(\mathrm{d})]}\end{array}$ & Any & $\begin{array}{l}\text { Solid } \\
\text { waste }\end{array}$ & $\begin{array}{l}\text { A waste must be evaluated to } \\
\text { determine whether it is a } \\
\text { hazardous waste, i.e., either a } \\
\text { listed waste or a characteristic } \\
\text { waste. A characteristic waste is } \\
\text { determined by its (1) ignitability, } \\
\text { (2) corrosivity, ( } 3 \text { ) reactivity, or } \\
\text { (4) leachability, as defined by } \\
\text { TCLP for several contaminants. }\end{array}$ & $\begin{array}{l}\text { Potentially } \\
\text { applicable }\end{array}$ & $\begin{array}{l}\text { This requirement is applicable to } \\
\text { the characterization and } \\
\text { management of site waste. One or } \\
\text { two samples have shown the } \\
\text { presence of leachable lead. } \\
\text { Further characterization is } \\
\text { ongoing. }\end{array}$ \\
\hline
\end{tabular}


TABLE A.3 Federal Regulations and To-Be-Considereds for J-Field - Potential Location-Specific Requirements

\begin{tabular}{|c|c|c|}
\hline Potential ARARs & Location & Requirements \\
\hline $\begin{array}{l}\text { Antiquity Act, Historic Sites Act } \\
\text { [16 USC } 431-433,16 \text { USC } \\
461-467,40 \text { CFR } 6.301(a)]\end{array}$ & Land & $\begin{array}{l}\text { Cultural resources, such as historic } \\
\text { buildings and sites and natural land- } \\
\text { marks, must be preserved on federal } \\
\text { land to avoid adverse impacts. }\end{array}$ \\
\hline $\begin{array}{l}\text { National Historic Preservation } \\
\text { Act, as amended [16 USC } 470 \text {, } \\
\text { et seq., } 40 \text { CFR } 6.301(\mathrm{~b}) \text {, } \\
36 \text { CFR Part } 800 \text { ] }\end{array}$ & Land & $\begin{array}{l}\text { The effect of any federally assisted } \\
\text { undertaking must be taken into account } \\
\text { for any district, site, building, structure, } \\
\text { or object included in or eligible for the } \\
\text { National Register of Historic Places. }\end{array}$ \\
\hline $\begin{array}{l}\text { Archaeological and Historic } \\
\text { Preservation Act [16 USC } 469 \text {, } \\
40 \text { CFR } 6.301(\mathrm{c}) \text {, PL 93-291, } \\
88 \text { Stat. 174] }\end{array}$ & Land & $\begin{array}{l}\text { Prehistorical, historical, and archae- } \\
\text { ological data that might be destroyed as } \\
\text { a result of a federal, federally assisted, } \\
\text { or federally licensed activity or program } \\
\text { must be preserved. }\end{array}$ \\
\hline $\begin{array}{l}\text { Archaeological Resources Pro- } \\
\text { tection Act [16 USC } 470(\mathrm{a}) \text { ] }\end{array}$ & Land & $\begin{array}{l}\text { A permit must be obtained if an action } \\
\text { on public or Native American lands } \\
\text { could affect archaeological resources. }\end{array}$ \\
\hline $\begin{array}{l}\text { Protection and Enhancement of } \\
\text { the Cultural Environment (EO } \\
\text { 11593, 40 CFR 6.301) }\end{array}$ & Land & $\begin{array}{l}\text { Historic, architectural, archaeological, } \\
\text { and cultural resources must be } \\
\text { preserved, restored, and maintained, } \\
\text { and must be evaluated for inclusion in } \\
\text { the National Register of Historic Places. }\end{array}$ \\
\hline $\begin{array}{l}\text { Endangered Species Act, as } \\
\text { amended [16 USC 1531-1543, . } \\
\text { 50 CFR } 17.402,40 \text { CFR } 6.302(\mathrm{~h})]\end{array}$ & Any & $\begin{array}{l}\text { Federal agencies must ensure that any } \\
\text { action authorized, funded, or carried } \\
\text { out by the agency is not likely to } \\
\text { jeopardize the continued existence of } \\
\text { any threatened or endangered species } \\
\text { or destroy or adversely modify any } \\
\text { critical habitat. }\end{array}$ \\
\hline
\end{tabular}

Preliminary

Determination

Remarks

Potentially applicable

Potentially applicable

Potentially applicable

Potentially applicable

Potentially applicable

Potentially applicable
Should the J-Field site be identified as a cultural resource, the requirement could be potentially applicable during a remedial action.

Should such a property be identified, the requirement would be potentially applicable during a remedial action.

Should such data be identified, the requirement would be potentially applicable during a remedial action.

Should such resources be identified, the requirement would be potentially applicable during a remedial action.

Should such resources be identified, the requirement would be potentially applicable during a remedial action.

Should such species or habitat exist, the requirement would be potentially applicable during a remedial action. 
TABLE A.3 (Cont.)

\begin{tabular}{|c|c|c|c|c|}
\hline Potential ARARs & Location & Requirements & $\begin{array}{c}\text { Preliminary } \\
\text { Determination }\end{array}$ & Remarks \\
\hline $\begin{array}{l}\text { Fish and Wildlife Coordination } \\
\text { Act [14 USC } 441-444 \text {, } \\
40 \text { CFR } 4.302(a) \text { ] }\end{array}$ & Any & $\begin{array}{l}\text { Adequate protection of fish and wildlife } \\
\text { resources is required when any federal } \\
\text { department or agency proposes or } \\
\text { authorizes any modification (e.g., } \\
\text { diversion or channeling) of any stream } \\
\text { or other water body or any modification. } \\
\text { of areas affecting any stream or other } \\
\text { water body. }\end{array}$ & $\begin{array}{l}\text { Potentially } \\
\text { applicable }\end{array}$ & $\begin{array}{l}\text { Should modification of any stream or } \\
\text { any other water bodies or areas } \\
\text { affecting water bodies be required } \\
\text { during a remedial action, the } \\
\text { requirement would be potentially } \\
\text { applicable. }\end{array}$ \\
\hline $\begin{array}{l}\text { Floodplain Management } \\
\text { (EO 11988) }\end{array}$ & Floodplain & $\begin{array}{l}\text { Federal agencies must avoid, to the } \\
\text { maximum extent possible, any adverse } \\
\text { impacts associated with direct and } \\
\text { indirect development of a floodplain. }\end{array}$ & $\begin{array}{l}\text { Potentially } \\
\text { applicable }\end{array}$ & $\begin{array}{l}\text { The site is within the } 100 \text {-year } \\
\text { floodplain. }\end{array}$ \\
\hline $\begin{array}{l}\text { Protection of Wetlands } \\
\text { (EO 11990) }\end{array}$ & Wetlands & $\begin{array}{l}\text { Federal agencies must avoid, to the } \\
\text { extent possible, any adverse impacts } \\
\text { associated with the destruction or loss } \\
\text { of wetlands and the support of new } \\
\text { construction in wetlands if a practicable } \\
\text { alternative exists. }\end{array}$ & $\begin{array}{l}\text { Potentially } \\
\text { applicable }\end{array}$ & Wetlands exist in the affected area. \\
\hline
\end{tabular}


TABLE A.4 Federal Regulations and To-Be-Considereds for J-Field - Potential Action-Specific Requirements

\begin{tabular}{|c|c|c|c|c|}
\hline Potential ARARs & Action & Requirements & $\begin{array}{c}\text { Preliminary } \\
\text { Determination }\end{array}$ & Remarks \\
\hline $\begin{array}{l}\text { Hazardous Material } \\
\text { Transportation Act, as } \\
\text { amended ( } 49 \text { USC 1801- } \\
\text { 1812); } \\
\text { Solid Wastes (40 CFR } \\
\text { Part 263) }\end{array}$ & Transportation & $\begin{array}{l}\text { Generic requirements are established, } \\
\text { as are procedures for transporting } \\
\text { hazardous waste, for minimizing the } \\
\text { environmental impacts of spills or } \\
\text { releases of hazardous materials. }\end{array}$ & $\begin{array}{l}\text { Potentially } \\
\text { applicable }\end{array}$ & $\begin{array}{l}\text { These requirements are not part of } \\
\text { an environmental law and hence are } \\
\text { not subject to evaluation for attain- } \\
\text { ment or waiver as part of the ARAR } \\
\text { process. However, they could be } \\
\text { pertinent to any remedial action in } \\
\text { which hazardous waste is trans- } \\
\text { ported off-site. In this case, the } \\
\text { pertinent requirements (e.g., for spill } \\
\text { response) would be addressed during } \\
\text { implementation. }\end{array}$ \\
\hline $\begin{array}{l}\text { Noise Control Act, as } \\
\text { amended; Noise Pollution } \\
\text { and Abatement Act } \\
\text { (42 USC 4901, et seq.) }\end{array}$ & $\begin{array}{l}\text { Detonation, } \\
\text { heavy } \\
\text { equipment } \\
\text { usage }\end{array}$ & $\begin{array}{l}\text { The public must be protected from noises } \\
\text { (e.g., that could result from remedial } \\
\text { action activities) that jeopardize health or } \\
\text { welfare. }\end{array}$ & $\begin{array}{l}\text { Potentially } \\
\text { applicable }\end{array}$ & $\begin{array}{l}\text { This requirement is potentially } \\
\text { applicable if during a remedial action } \\
\text { any detonation of UXO occurs and } \\
\text { heavy equipment is used. }\end{array}$ \\
\hline $\begin{array}{l}\text { OSHA Standards for } \\
\text { Hazardous Waste } \\
\text { Operations and } \\
\text { Emergency Response } \\
\text { (29 CFR Part 1910) }\end{array}$ & $\begin{array}{l}\text { Waste } \\
\text { management }\end{array}$ & $\begin{array}{l}\text { General worker protection requirements } \\
\text { are established, as are requirements for } \\
\text { worker training and the development of } \\
\text { an emergency response plan and a safety } \\
\text { and health program for employees. In } \\
\text { addition, procedures are established for } \\
\text { hazardous waste operations, including } \\
\text { decontamination and drum/container } \\
\text { handling (e.g., for radioactive waste, } \\
\text { asbestos, and PCBs). }\end{array}$ & $\begin{array}{l}\text { Potentially } \\
\text { applicable }\end{array}$ & $\begin{array}{l}\text { These requirements are parts of an } \\
\text { employee protection law (rather than } \\
\text { an environmental law) with which all } \\
\text { CERCLA response actions should } \\
\text { comply. Because this compliance is } \\
\text { directly required, as promulgated in } \\
\text { the NCP, these requirements are not } \\
\text { subject to evaluation for attainment } \\
\text { or waiver as part of the ARAR } \\
\text { process. However, they constitute } \\
\text { requirements for worker protection } \\
\text { with which a remedial action will } \\
\text { comply. }\end{array}$ \\
\hline
\end{tabular}


TABLE A.4 (Cont.)

\begin{tabular}{|c|c|c|c|c|}
\hline Potential ARARs & Action & Requirements & $\begin{array}{c}\text { Preliminary } \\
\text { Determination }\end{array}$ & Remarks \\
\hline $\begin{array}{l}\text { TSCA, as amended } \\
\text { (15 USC 2607-2629, } \\
\text { PL 94-469, et seq.); } \\
\text { Polychlorinated Biphenyls } \\
\text { Manufacturing, Proces- } \\
\text { sing, Distribution in } \\
\text { Commerce, and Use } \\
\text { Prohibitions (40 CFR } 761 \\
\text { Subpart A) }\end{array}$ & PCB testing & $\begin{array}{l}\text { Inspection and testing are required for } \\
\text { material contaminated with } \mathrm{PCBs} \text {. }\end{array}$ & $\begin{array}{l}\text { Potentially } \\
\text { applicable }\end{array}$ & $\begin{array}{l}\text { This requirement may be applicable } \\
\text { to characterization of site waste for } \\
\text { PCBs. }\end{array}$ \\
\hline $\begin{array}{l}\text { TSCA, as amended } \\
\text { (15 USC 2607-2629, } \\
\text { PL 94-499, et seq.) } \\
\text { Polychlorinated Biphenyls } \\
\text { Manufacturing, Proces- } \\
\text { sing, Distribution in Com- } \\
\text { merce, and Use } \\
\text { Prohibitions (40 CFR } 761 \\
\text { Subpart D) }\end{array}$ & $\begin{array}{l}\text { PCB storage } \\
\text { and disposal }\end{array}$ & $\begin{array}{l}\text { When material contaminated with } \\
\text { PCBs }>50 \mathrm{ppm} \text { is stored, the facility used } \\
\text { for storage must be marked as such and } \\
\text { must not be located in a } 100 \text {-year } \\
\text { floodplain. PCBs may not be stored for } \\
\text { more than } 1 \text { year before disposal. } \\
\text { Disposal of material contaminated with } \\
\text { PCBs }>50 \text { ppm requires either } \\
\text { incineration or chemical waste landfilling } \\
\text { at EPA-approved facilities. }\end{array}$ & $\begin{array}{l}\text { Potentially } \\
\text { relevant and } \\
\text { appropriate }\end{array}$ & $\begin{array}{l}\text { These requirements are potentially } \\
\text { relevant and appropriate because } \\
\text { disposal of material from the site } \\
\text { that may be contaminated with PCBs } \\
\text { may be included in the scope of the } \\
\text { remedial action. }\end{array}$ \\
\hline
\end{tabular}


TABLE A.4 (Cont.)

\begin{tabular}{|c|c|c|c|c|}
\hline Potential ARARs & Action & Requirements & $\begin{array}{c}\text { Preliminary } \\
\text { Determination }\end{array}$ & Remarks \\
\hline $\begin{array}{l}\text { Solid Waste Disposal Act, } \\
\text { as amended ( } 42 \text { USC } \\
6901 \text {, et seq.); } \\
\text { Hazardous Wastes } \\
\text { [40 CFR 264(b-e)] }\end{array}$ & $\begin{array}{l}\text { Waste treat- } \\
\text { ment, storage, } \\
\text { and disposal } \\
\text {. }\end{array}$ & $\begin{array}{l}\text { General requirements are established for } \\
\text { treatment, storage, and disposal (TSD) } \\
\text { facility location, design, and inspection; } \\
\text { waste compatibility determination; } \\
\text { emergency contingency plans; } \\
\text { preparedness plans; recordkeeping; } \\
\text { reporting; and worker training. Location } \\
\text { requirements include (1) facilities must } \\
\text { not be located within } 61 \mathrm{~m} \text { ( } 200 \mathrm{ft} \text { ) of an } \\
\text { active fault and (2) facilities located in a } \\
100 \text {-year floodplain must be constructed, } \\
\text { operated, and maintained to prevent } \\
\text { washout of any hazardous waste by a } \\
100 \text {-year flood. }\end{array}$ & $\begin{array}{l}\text { Potentially } \\
\text { applicable }\end{array}$ & $\begin{array}{l}\text { These requirements are potentially } \\
\text { applicable because storage, } \\
\text { treatment, or disposal, as defined } \\
\text { under RCRA, may be included in the } \\
\text { scope of a remedial action. In } \\
\text { addition, the ongoing OB/OD } \\
\text { activities at J-Field will mean that } \\
\text { Subpart X, Miscellaneous Units, } \\
\text { could be a key ARAR. Soil storage } \\
\text { over } 90 \text { days before treatment or off- } \\
\text { site shipment must meet these } \\
\text { general requirements (containment } \\
\text { buildings [40 CFR } 264 \text { Subpart DD] } \\
\text { or waste piles [40 CFR } 264 \\
\text { Subpart L]). Soil washing, as a } \\
\text { treatment activity, must meet these } \\
\text { general requirements ( } 40 \text { CFR } 264 \\
\text { Subpart X). Storage of wastewater } \\
\text { from pump-and-treat activities in } \\
\text { tanks for over } 90 \text { days must meet } \\
\text { these general requirements } \\
\text { (40 CFR } 264 \text { Subpart J). Such } \\
\text { storage tanks would also have to } \\
\text { meet new VOC emission standards at } \\
\text { TSD facilities (59 FR } 62,896, \text { Dec. } 6 \text {, } \\
1994 \text {; } 40 \text { CFR Part } 264 \text { Subpart CC). } \\
\text { Any facility, whether storage or } \\
\text { treatment, must meet the } \\
\text { requirements for closure ( } 40 \text { CFR } 264 \\
\text { Subpart G). }\end{array}$ \\
\hline
\end{tabular}


TABLE A.4 (Cont.)

\begin{tabular}{|c|c|c|c|c|}
\hline Potential ARARs & Action & Requirements & $\begin{array}{l}\text { Preliminary } \\
\text { Determination }\end{array}$ & Remarks \\
\hline $\begin{array}{l}\text { Solid Waste Disposal Act, } \\
\text { as amended ( } 42 \text { USC } \\
6901 \text {, et seq.); } \\
\text { Hazardous Wastes } \\
\text { (40 CFR } 264 \text { Subpart F) }\end{array}$ & Waste disposal & $\begin{array}{l}\text { A groundwater monitoring system must } \\
\text { be maintained for an SWMU. The } \\
\text { concentration of a hazardous constituent } \\
\text { in the uppermost aquifer beneath a } \\
\text { regulated unit is not to exceed the } \\
\text { existing background concentration or a } \\
\text { listed maximum concentration if higher } \\
\text { than the background level, or an } \\
\text { alternate concentration limit, unless an } \\
\text { exemption is granted. See } 40 \text { CFR } \\
\text { Part } 264 \text { for organic and inorganic } \\
\text { parameter requirements. }\end{array}$ & $\begin{array}{l}\text { Potentially } \\
\text { applicable }\end{array}$ & $\begin{array}{l}\text { These requirements are potentially } \\
\text { applicable if the scope of a remedial } \\
\text { action includes maintaining or } \\
\text { capping an SWMU. }\end{array}$ \\
\hline $\begin{array}{l}\text { Solid Waste Disposal Act, } \\
\text { as amended ( } 42 \text { USC } \\
6901 \text {, et seq.); } \\
\text { Hazardous Wastes } \\
\text { (40 CFR } 264 \text { Subpart I) }\end{array}$ & Waste storage & $\begin{array}{l}\text { Containers used to store hazardous waste } \\
\text { must be closed and in good condition. }\end{array}$ & $\begin{array}{l}\text { Potentially } \\
\text { applicable }\end{array}$ & $\begin{array}{l}\text { These requirements may be } \\
\text { applicable to the remedial action, } \\
\text { container storage, and transportation } \\
\text { of site waste that meets the pre- } \\
\text { requisites for definition as } \\
\text { characteristic hazardous waste. }\end{array}$ \\
\hline $\begin{array}{l}\text { Solid Waste Disposal Act, } \\
\text { as amended ( } 42 \text { USC } \\
6901 \text {, et seq.); } \\
\text { Land Disposal Restrictions } \\
\text { (40 CFR } 268 \text { Subpart C); } \\
\text { Land Disposal Restrictions } \\
\text { for Newly Identified and } \\
\text { Listed Hazardous Wastes } \\
\text { and Hazardous Soil, } \\
\text { Proposed Rules } \\
\text { (58 FR 48092, Sept. 14, } \\
\text { 1993) }\end{array}$ & Waste disposal & $\begin{array}{l}\text { The land disposal of certain hazardous } \\
\text { waste (e.g., contaminated soil and debris) } \\
\text { without proper treatment is restricted, } \\
\text { unless a treatability variance is appro- } \\
\text { priate. Such treatment must attain } \\
\text { levels achievable by the "best demon- } \\
\text { strated available technologies" for each } \\
\text { hazardous constituent in the listed waste. }\end{array}$ & $\begin{array}{l}\text { Potentially } \\
\text { applicable }\end{array}$ & $\begin{array}{l}\text { These requirements are potentially } \\
\text { applicable for any remedial action at } \\
\text { J-Field that includes disposal or any } \\
\text { consolidation of site waste into a new } \\
\text { disposal or storage area. The } \\
\text { proposed rules may impose different } \\
\text { land disposal restriction (LDR) } \\
\text { treatment standards on } \\
\text { contaminated soils. Also, see below } \\
\text { for the applicability of LDRs for } \\
\text { placement of excavated soils in } \\
\text { corrective action management units. }\end{array}$ \\
\hline
\end{tabular}


TABLE A.4 (Cont.)

\begin{tabular}{|c|c|c|c|c|}
\hline Potential ARARs & Action & Requirements & $\begin{array}{l}\text { Preliminary } \\
\text { Determination }\end{array}$ & Remarks \\
\hline $\begin{array}{l}\text { Solid Waste Disposal Act, } \\
\text { as amended ( } 42 \text { USC } \\
6901 \text {, et seq.); Hazardous } \\
\text { Wastes ( } 40 \text { CFR } 264 \\
\text { Subpart S) }\end{array}$ & $\begin{array}{l}\text { Waste } \\
\text { Disposal }\end{array}$ & $\begin{array}{l}\text { For the purpose of implementing a RCRA } \\
\text { corrective action, placement of } \\
\text { remediation wastes into an EPA- } \\
\text { designated corrective action management } \\
\text { unit does not constitute land disposal and } \\
\text { the LDRs and minimum technology } \\
\text { requirements for TSD facilities do not } \\
\text { apply. }\end{array}$ & $\begin{array}{l}\text { Potentially } \\
\text { applicable }\end{array}$ & $\begin{array}{l}\text { These requirements could be } \\
\text { applicable to the placement of the } \\
\text { excavated soils before treatment or } \\
\text { off-site disposal or to the capping of } \\
\text { areas of contaminated soil without } \\
\text { excavation or treatment. }\end{array}$ \\
\hline $\begin{array}{l}\text { CERCLA, as amended } \\
\text { (42 USC 6901, et seq.) }\end{array}$ & $\begin{array}{l}\text { Waste } \\
\text { Disposal }\end{array}$ & $\begin{array}{l}\text { Wastes may only be shipped to off-site } \\
\text { facilities that are in compliance with all } \\
\text { applicable RCRA requirements, } \\
\text { particularly certification that the } \\
\text { receiving unit has no releases of } \\
\text { hazardous constituents to the } \\
\text { environment. }\end{array}$ & $\begin{array}{l}\text { Potentially } \\
\text { applicable }\end{array}$ & $\begin{array}{l}\text { These requirements apply to any } \\
\text { shipments of hazardous wastes to off- } \\
\text { site TSD facilities, including } \\
\text { excavated soils. }\end{array}$ \\
\hline
\end{tabular}


$B-1$

APPENDIX B:

IDENTIFICATION OF POTENTIAL AREAS OF CONCERN AT J-FIELD 


$$
\text { B-2 }
$$




\section{APPENDIX B:}

\section{IDENTIFICATION OF POTENTIAL AREAS OF CONCERN AT J-FIELD}

\section{B.1 INTRODUCTION}

This appendix describes the methodology used to identify the potential areas of concern (PAOCs) at J-Field, documents the PAOCs on the basis of historical photograph analysis, and reports the results of the PAOC inspections performed April 12-15, 1994, and May 11, 1994.

The methodology used to select the PAOCs is described in Section B.2. The PAOCs are documented and the site inspection results presented in Section B.3. The PAOCs are divided into three groups. One group contains sites that are not associated with the eight AOCs, the second group includes sites associated with the identified AOCs, and the third group includes all craters at J-Field. The PAOCs in the first group could become new AOCs in the future if sampling and analysis indicated contamination were present. The PAOCs in the second group will be incorporated into their corresponding AOCs for study in the Remedial Investigation. The third group, fieldwide craters, will be addressed in the Ecological Risk Assessment Work Plan.

\section{B.2 METHODOLOGY FOR IDENTIFYING PAOCs}

The PAOCs were designated on the basis of information from two sources: (1) the 1986 RFA (Nemeth 1989), which includes a review of archival information and personnel interviews; and (2) analysis of historical aerial photographs. The photographic analysis involved a brief review of aerial photographs dated 1951, 1957, 1960, 1970, and 1981 (Nemeth 1989) and a detailed analysis of aerial photographs dated 1965 and 1968 (U.S. Army 1965; USGS 1968). The identified PAOCs include areas that show man-made features (such as clearing areas, geometric patterns, and ground scarring), and structures (such as buildings, trenches, storage areas, and roads) on aerial photographs. Their locations are shown in Figure B.1.

The PAOCs identified were inspected in the field April 12-15, 1994, and May 11,

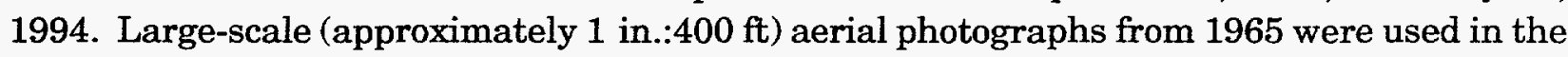
field. Features that may reflect previous human activities such as soil piles, metal, and other man-made debris; structure ruins; bomb craters; road tracks; and shallow depressions of regular shape were recorded. The condition of vegetation within and around a PAOC was also documented. On the basis of these features and aerial photographic interpretation, an attempt was made (when possible) to determine the nature of the past activities on each PAOC. 


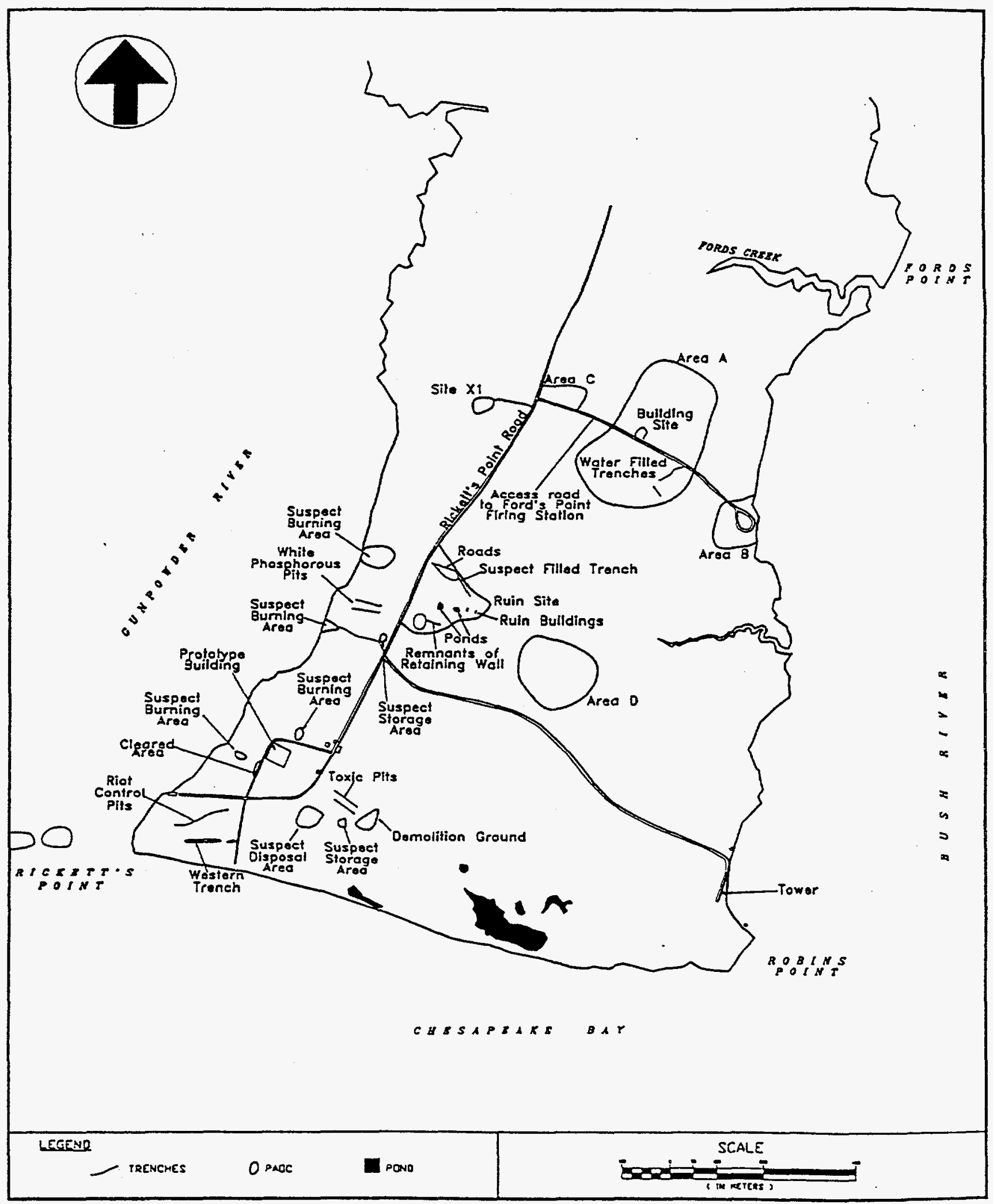

FIGURE B.1 Locations of PAOCs at J-Field 


\section{B.3 FIELD INSPECTION RESULTS}

A total of 17 PAOCs have been inspected. They are Site X1, Areas A to D, two suspected storage areas associated with the Toxic Burning Pits (TBP) area and the White Phosphorous Burning Pits (WPP) area, four suspected burning areas (two near the WPP and two near the Prototype Building), one suspected filled trench (near the South Beach Trench area), one clearing near the southwest corner of the Prototype Building, one suspected disposal area (southwest of the TBP area), the craters of J-Field, one demolition area (southeast of the TBP area), and one ruins site (east of the WPP area). The locations and features of these PAOCs are shown in Figure B.1 and described in the following sections.

For discussion purposes the PAOCs are separated into three groups: those not associated with AOCs (Section B.3.1), those that are (Section B.3.2), and craters (Section B.3.3). Within each group, the PAOCs are described sequentially based on their locations, from north to south.

\section{B.3.1 PAOCs Not Associated with AOCs}

\section{B.3.1.1 Site X1}

Site $\mathrm{X} 1$ is in the northwestern part of J-Field, about $300 \mathrm{ft}$ southwest of the intersection of Rickett's Point Road and the access road to the Ford's Point Firing Position. In 1965 aerial photographs, the site was a cleared area with a size of about 120 by $100 \mathrm{ft}$. An access road starting from Rickett's Point Road ended at the site. The access road bed is still discernable in the field today.

The site includes two ruins subsites about $100 \mathrm{ft}$ apart. Collapsed concrete columns are present on the ground at each subsite. Both subsites are surrounded by a ridge of soil piles. The vegetation is much younger within the subsites than in the surrounding areas. A brick wall foundation is visible on the ground in the eastern subsite. A small drum emerges among a soil pile in the western ruin. No bomb craters are found near this site.

Three very shallow depressions with ponded water were identified. All are near the access road. The first shallow depression is about $100 \mathrm{ft}$ from the entrance of the access road and is perpendicular to the road. The second and third depressions are parallel to the access road and are near the first one. Each depression seems to be rectangular and about $6 \mathrm{ft}$ wide. They may represent filled trenches. Site X1 has been present since as early as 1951 (Nemeth 1989). Its use is not known.

\section{B.3.1.2 Area A}

Located in the northern part of J-Field, Area A is characterized by grids of linear features and two water-filled trenches, as they appeared on aerial photographs. The access road to the Ford's Point Firing Station dissects the central part of the site. When inspected 
in the field, the site was swampy. The grid pattern shown on aerial photographs is caused by grids of drainage commonly used to drain wetlands in this region.

One S-shaped trench and one straight trench are present within the drainage grid. The S-shaped trench is located immediately adjacent to the road and is separated from the straight trench by a dirt pile. Both trenches are about 6-7 ft wide. No scrap metal has been found nearby on the ground surface. The past use of the trenches is unclear.

About $400 \mathrm{ft}$ west of the S-shaped trench is an old building site. A small shack appears there in 1965 aerial photographs. The ground now is scattered with a few glass bottles and ceramic sherds. Soil piles surround the site. A prominent, straight, long drainage about $3 \mathrm{ft}$ wide extends from behind the site to the swamp north of J-Field. This drainage is readily noticeable in aerial photographs.

\section{B.3.1.3 Area B (Ford's Point Firing Station)}

Area $B$ is a large open area at the eastern end of an access road in the northern part of J-Field and near the Bush River. It is also referred to Ford's Point Firing Station. Aerial photographs show that the site has existed since as early as 1951 . The site is covered with reed grass (Phragmites). Concrete slabs are piled up near the shore of the Bush River, probably protecting the shore from erosion. Near the southern part of the site a pile of concrete chunks embedded with hollow pipes is present. Soil mounds are present near the western boundary of the site. Two small scrap drums were found on the ground surface near the soil mounds. The past use of the site is not known.

\section{B.3.1.4 Area C}

Area $\mathrm{C}$ is a ruin site near the entrance of the access road to Ford's Point Firing Station. Aerial photographs from 1965 show two buildings near the intersection of the access road and Rickett's Point Road, and a wall near the eastern part of the site. The buildings were destroyed before 1968, as indicated in later aerial photographs. In the field, remnants of a standing concrete wall and bricks are left on the ground surface. Bomb craters are visible near the site. The destroyed buildings probably were used for access control to the Ford's Point Firing Station, while the concrete wall in the eastern part of the site was probably a test site for bombing structures.

\section{B.3.1.5 Ruins Site Across Road from WPP}

A ruins site located across Rickett's Point Road from the WPP includes two building ruins, two connected artificial ponds, four retaining wall structures, and a suspected filled trench. These features are discernable in the 1965 aerial photographs. The western part of the site, where the two building ruins are located, was flooded when the site was inspected. 
The site was used for munitions testing in World War II. Bomb craters are common, especially near the four retaining wall structures. Probably due to bombing, only remnants of buttressed columns and partially destroyed steel-reinforced walls remain in the field. No visible metal scrap has been found on the ground surface. The ruin buildings are in the eastern part of the site. One is a steel-reinforced concrete building, and the other is a steelreinforced brick building. Circular-shaped scars are common on the building's outside walls. Two small ponds connected by a ditch are near the southern part of the site. One of the ponds is rectangular in shape, the other is irregularly shaped. The past use of the ponds is not known.

A suspected filled trench, about $7-8 \mathrm{ft}$ wide, was identified in an area about $80 \mathrm{ft}$ southeast of the ruin buildings. It is partially ponded with water. The suspected filled trench extends southeast for more than $100 \mathrm{ft}$. Traces of road bed are discernable near its end. The roads connect to Rickett's Point Road. A steel tube with a cylinder built inside was found next to a pile of soil between the filled trench and the two building ruins. The past use of the trench is not clear.

A dark-toned area appears in the southwestern part of the site in the 1965 aerial photographs. This area was inspected in the field and was found to be flat and covered with vegetation that is younger than in the surrounding area. No scrap metal was found on the ground surface. The previous use of this area is unknown.

\section{B.3.1.6 Area D}

Area $\mathrm{D}$, located about $400 \mathrm{ft}$ east of the ruins site, is a flooded swamp area. The area has a dark tone in aerial photographs and is dotted with many craters. No road extends to this site. The site probably was used for targeting.

\section{B.3.2 PAOCs Associated with AOCs}

\section{B.3.2.1 Storage Area of WPP}

The suspected storage area, about 30 by $20 \mathrm{ft}$, is in the southeastern corner of the WPP AOC and about $40 \mathrm{ft}$ west of Rickett's Point Road. Some materials are shown on the ground surface in the 1965 aerial photographs. The storage area was observed in the field to be surrounded by piles of soil.

\section{B.3.2.2 Suspected Burning Area near Northwestern Corner of WPP}

This site is in the northwestern corner of the WPP AOC and is covered with reed grass. The 1965 aerial photographs show three suspected burning areas clustered together on this site. Each area was circular in shape, with a diameter about $30 \mathrm{ft}$, and appeared as a dark-toned area in the aerial photographs. Mounds of soil were observed in the field to be 
piled near its northern boundary. A few pieces of scrap metal were scattered nearby. The specific past use of the site is not known.

\section{B.3.2.3 Suspected Burning Area near Southwestern Corner of WPP}

This area appeared as a demolition area in aerial photographs. By the shore of Gunpowder River and at the southwestern corner of the WPP AOC, the area is covered by abundant shells of small arms, grenade caps, 50-caliber shells, and melted glass. Away from the shore, most of the area is covered by reeds (Phragmites). Judging from field observations, this site likely was used for small ammunition demolition.

\section{B.3.2.4 Suspected Burning Area near Northeastern Corner of Prototype Building}

This area appeared in the 1965 aerial photographs as an oval-shaped clearing with three small structures in its western portion. The area is covered with grasses today. The three structures probably were grills. Only one of the structures, with a size of 3 by $3 \mathrm{ft}$, is still in the field. Pieces of silver-like melted metals and charcoals are still visible in the grill. The original clearing area is free from metallic objects. The previous use of the site is unknown.

\section{B.3.2.5 Clearing near Southwestern Corner of Prototype Building}

This area was shown as a clearing in aerial photographs as early as 1951 . No scrap metal was found near the site when it was inspected. There is no evidence to suggest that management or disposal of wastes was carried out at this site.

\section{B.3.2.6 Suspected Burning Area near Southwestern Portion of Prototype Building}

The area appears as a demolition ground in aerial photographs. The site is about $200 \mathrm{ft}$ west of the Prototype Building and near the edge of the woods. Its southern boundary is marked by piles of soil, and its northern boundary is marked by tall reeds and shallow ponded water. Very few trees grow on the site. A rusty empty drum and a belt-shaped piece of scrap metal were found on the ground surface.

\section{B.3.2.7 Western Trench of South Beach Trench Area}

This suspected trench is filled, and it is located about $40 \mathrm{ft}$ west of the current South Beach Trench. In aerial photographs, the western trench is oriented east-west and extends more than $300 \mathrm{ft}$. Some waste was observed in its central and eastern portions. The central 
portion of the trench was once accessible by a road from the south. The filled trench is still discernable in the field. Small drums and cans are scattered in the woods nearby.

\section{B.3.2.8 Storage Area of TBP Area}

Located near the southeastern corner of the TBP area and by the edge of the woods, the storage area is a fenced area about 30 by $30 \mathrm{ft}$. In the 1965 aerial photographs, drums were shown being unloaded from a truck and moved through a track to the storage area. This area probably was used for temporary storage before wastes were disposed in the TBP area.

\section{B.3.2.9 Suspected Disposal Area near Southwestern Portion of TBP Area}

Located in the southwestern portion of the TBP area, this site is shown cleared of nearly all vegetation in late 1950s aerial photographs. In 1965 aerial photographs, soil in the western part of the site is pushed out to the south into the marsh. In the field, the site is covered with reed grass with a few old trees. Near its northern edge, a square pit, about 4 by $4 \mathrm{ft}$ and made of steel, emerges from the ground. The pit is filled with sand. No scrap metals, except for a barbed wire next to an old tree, were seen on the ground surface. The specific use of the site is unknown.

\section{B.3.2.10 Demolition Area near Southeastern Portion of TBP Area}

Documented in the RFA (Nemeth 1989), this site was used for demolition of high-explosive munitions. The site was active in as early as 1965 , as seen in aerial photographs. Piles of scrap metals and soils are common on the ground near the site, especially near the marsh.

\section{B.3.3 Craters}

Numerous craters are distributed across J-Field. The craters are visible in largescale historical aerial photographs and in the field. Many of these craters fill with water in the spring.

\section{B.4 REFERENCES}

Nemeth, G., 1989, RCRA Facility Assessment, Edgewood Area, Aberdeen Proving Ground, $M D, 39-26-0490-90$, U.S. Army Environmental Hygiene Agency, Waste Disposal Engineering Division, Aberdeen Proving Ground, Md., Nov. 
U.S. Army, 1965, aerial photograph of Edgewood Area, roll no. G\&O 85047, frame nos. 8-1 to 8-2 and 9-1 to 9-4, Environmental Hygiene Agency, Aberdeen Proving Ground, Md.

USGS — see U.S. Geological Survey.

U.S. Geological Survey, 1968, aerial photographs, roll no. ABB044140000303, frame nos. 118-120, Washington, D.C. 